\title{
8. SITES 270, 271, 272
}

\section{The Shipboard Scientific Party'}

\section{SITE DATA, SITE 270}

Date Occupied: 29 January 1973

Date Departed: 3 February 1973

Position: $77^{\circ} 26.48^{\prime} \mathrm{S} ; 178^{\circ} 30.19^{\prime} \mathrm{W}$

Water Depth: 633 corrected meters (echo sounding)

Water Depth (adopted): 634 meters (drill pipe from rig floor)

Total Penetration: 422.5 meters

Number of Cores: 49

Total Section Cored: 422.5 meters

Total Section Recovered: 263.7 meters

Percentage Core Recovery: $62 \%$

Oldest Sediment Cored:

Depth below sea floor: 422.5 meters

Lithology: Breccia

Age: Oligocene

\section{Basement:}

Depth below sea floor: $0.39 \mathrm{sec}$ (reflection time)

Depth below sea floor: $\sim 390$ meters (drilled)

Average velocity to basement: $\sim 2.0 \mathrm{~km} / \mathrm{sec}$

Lithology: Marble/calc-silicate gneiss

Principal Results: Glacial deposits, most bearing marine invertebrate fossils, occur to a subbottom depth of about 385 meters and range in age from Recent back to late Oligocene. The angular unconformity apparent on the seismic profile is present at about 20 meters subbottom, a marked increase in lithification and an early Pliocene to early Miocene stratigraphic hiatus. As rock types typical of the Transantarctic Mountains were rarely found, the likely source area for much of the glacial debris may have been Marie Byrd Land, although this area is poorly known geologically. Below the glacial sediments 2-5 meters of glauconitic sand and carbonaceous sandstone of middle/late? Oligocene age occurs. This in turn is underlain by a sedimentary breccia about 30 meters thick. The

\footnotetext{
'Dennis E. Hayes, Lamont-Doherty Geological Observatory, Palisades, New York (Co-chief scientist); Lawrence A. Frakes, Florida State University, Tallahassee, Florida (Present address: Monash University, Clayton, Victoria, Australia) (Co-chief scientist); Peter J. Barrett, Victoria University of Wellington, Wellington, New Zealand; Derek A. Burns, New Zealand Oceanographic Institute, Wellington, New Zealand; Pei-Hsin Chen, Lamont-Doherty Geological Observatory, Palisades, New York; Arthur B. Ford, U.S. Geological Survey, Menlo Park, California; Ansis G. Kaneps, Scripps Institution of Oceanography, La Jolla, California; Elizabeth M. Kemp, Florida State University, Tallahassee, Florida (Present address: Bureau of Mineral Resources, Canberra City, Australia); David W. McCollum, Florida State University, Tallahassee, Florida (University of South Carolina, Beufort, South Carolina); David J.W. Piper, Dalhousie University, Halifax, Nova Scotia; Robert E. Wall, National Science Foundation, Washington, D.C.; Peter N. Webb, New Zealand Geological Survey, Lower Hutt, New Zealand (Present address: Northern Illinois University, de Kalb, Illinois).
}

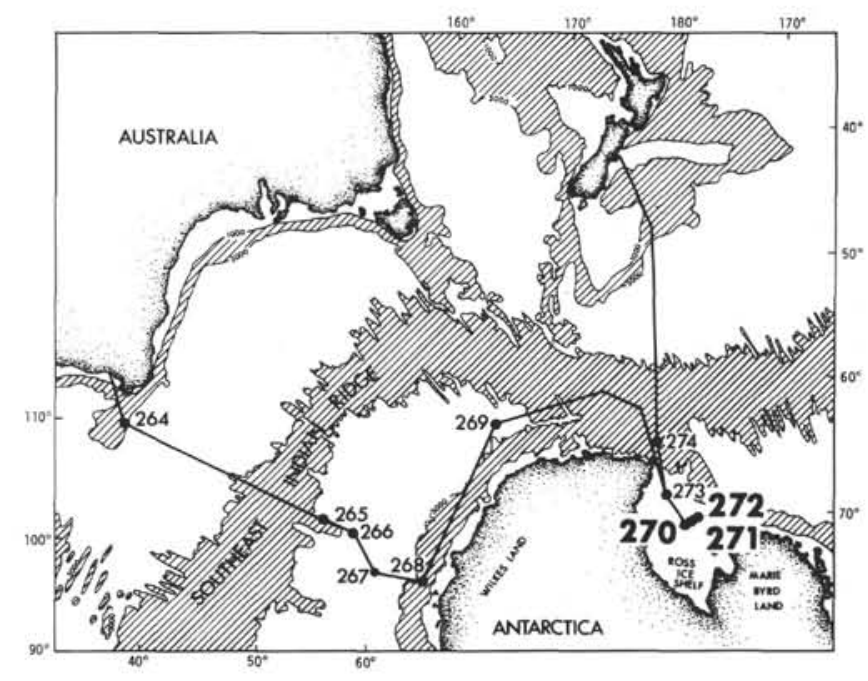

breccia probably represents a nearby source of metamorphic and igneous rocks as typically found in continental areas (e.g., granite, diorite, granite gneiss, etc.). The breccia rests nonconformably on gray foliated marble and calcsilicate gneiss of possible early Paleozoic age. The marble/gneiss unit exhibits high compressional wave velocities $(\sim 4 \mathrm{~km} / \mathrm{sec})$ and corresponds to the topographic high in the "acoustic basement" anticipated near 400 meters subbottom.

\section{SITE DATA, SITE 271}

Date Occupied: 3 February 1973

Date Departed: 5 February 1973

Position: $76^{\circ} 43.27^{\prime} \mathrm{S}$; $175^{\circ} 02.86^{\prime} \mathrm{W}$

Water Depth: 562 corrected meters (echo sounding)

Water Depth (adopted): 554 meters (drill pipe from rig floor)

Total Penetration: 265 meters

Number of Cores: 24

Total Section Cored: 233.0 meters

Total Section Recovered: 15.3 meters

Percentage Core Recovery: $7 \%$

Oldest Sediment Cored:

Depth below sea floor: 265 meters

Lithology: Silt/clay/sand mixtures

Age: Early Pliocene

Principal Results: Poor recovery at Site 271 allows little to be concluded about depositional conditions other than that a marine environment with iceberg rafting was in existence for most of the time back to the early Pliocene/late Miocene. Clasts are very abundant here, and their abundance was probably a contributing factor to the low recovery. 
Their concentration may reflect either high iceberg melting in the Neogene or the preferential location of the site near iceberg tracks. In view of the lack of stratification in the cores, reentrainment of fine-grained sediment, leaving a lag deposit of coarser materials as at Site 270, does not seem likely. Clast types are comparable with those at Site 270, suggesting no major change in provenance. The hole was terminated when the first evidence of gas was found in Core 24. The gas included small, but significant fractions of ethane and ethylene, in addition to methane.

\section{SITE DATA, SITE 272}

Date Occupied: 6 February 1973

Date Departed: 10 February 1973

Position: $77^{\circ} 07.62^{\prime} \mathrm{S} ; 176^{\circ} 45.61^{\prime} \mathrm{W}$

Water Depth: 619 corrected meters (echo sounding)

Water Depth (adopted): 629 meters (drill pipe from rig floor)

Total Penetration: 443 meters

Number of Cores: 48

Total Section Cored: 439 meters

Total Section Recovered: 162 meters

Percentage Core Recovery: $37 \%$

Oldest Sediment Cored:

Depth below sea floor: 443 meters

Lithology: Silty claystone

Age: Early Miocene

Principal Results: The sedimentary sequence consists of diamicton, diamictite, and grades of pebbly mud and mudstone, all of which show local, poorly developed stratification. Deposition of these sediments was in an open marine environment including sediment rafting by icebergs. Clast types suggest that Marie Byrd Land is likely the major source area, as in the older glacial deposits encountered at Site 270. Methane and trace quantities of ethane were encountered from about 45 meters downward, but showed no significant increase downhole. Extremely poor recovery within the lower 60 meters of the cored section is interpreted as an indication of dominantly sand layers there. The angular unconformity apparent on the seismic records is represented by an increase in lithification at about 25 meters subbottom and a probable early mid Pliocene to late Miocene stratigraphic hiatus. The hole was terminated prematurely, as a safety precaution.

\section{BACKGROUND}

Sites 270,271 , and 272 are located in the southeastern portion of the Ross Sea (Figure 1) in water depths ranging from about 550 to 650 meters. A series of 3-5 holes was originally planned for this area to sample a thick sequence $(>1.5 \mathrm{~km})$ of gently dipping strata $(1-2$ degrees) that are truncated at or within a few tens of meters of the sea floor. From the work of Houtz and Davey (1973), it has been demonstrated that the eastern Ross shelf area is generally underlain by a thinner sequence of low-velocity sediments than is the western Ross shelf area. The topographic relief of the western region is greater and the mean depth shallower than that of the eastern region (see Hayes and Davey, this volume and Figure 1). These two regions are separated structurally by a basement rise or high trending northward

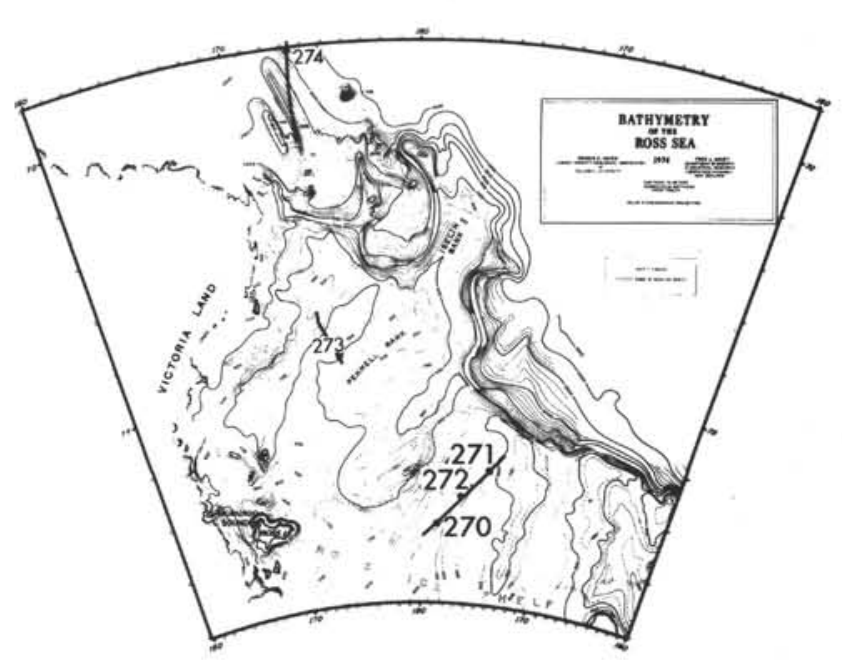

Figure 1. Location of Sites 270, 271, and 272 and bathymetry of the Ross Sea. Contours in meters (corrected). Solid line is track line for Eltanin 52 profile shown in Figure 2 (bottom).

near $180^{\circ}$ longitude. The basement is defined on the basis of an observed compressional wave velocity of 4-5 $\mathrm{km} / \mathrm{sec}$ and the sediments overlying the basement high are generally less than 500 meters thick (Houtz and Davey, 1973).

The disposition of the sediments, the location of the basement high, and the site locations are shown in Figure 2. The morphology of the Ross shelf consists of a series of northeasterly trending swales (Figure 1) and valleys (sometimes apparently channels) which appear in many instances to be erosional or scour surfaces. In some areas the relative topographic highs (or swales) may represent depositional features, probably moraines, such as shown to the northeast of Site 271; however, most swales probably resulted from glacial erosion associated with a grounded ice shelf. Figure 2 shows the line of holes intended to provide for penetration and sampling of about $1.5 \mathrm{~km}$ of the section by drilling several sites of modest penetration $(<650 \mathrm{~m})$. This sequence of holes lies within a valley or relative topographic low in accordance with a constraint imposed by DSDP on the minimum allowable water depth of 500 meters.

Because of the possible presence of hydrocarbons and the unusually shallow water which could compound the danger if high pressure hydrocarbons were encountered, the sites were to be continuously cored. One objective at Site 270 also included penetration and sampling of the high velocity basement judged to lie at a subbottom depth of about 400 meters. Objectives at Site 271 and at Site 272 were to penetrate sufficiently deep to overlap the top (youngest) of dipping strata sampled, respectively, at Site 272 and Site 270 . Site 272 was specifically located so as to be stratigraphically below the oldest strata sampled at Site 271 where methane and traces of ethane and ethylene were encountered.

Collectively, the sites were selected to address the questions of the initiation and fluctuations of the Ross ice shelf and continental glaciation in general and in particular to date and understand the origin of the pronounced angular unconformity shown in Figure 2. 

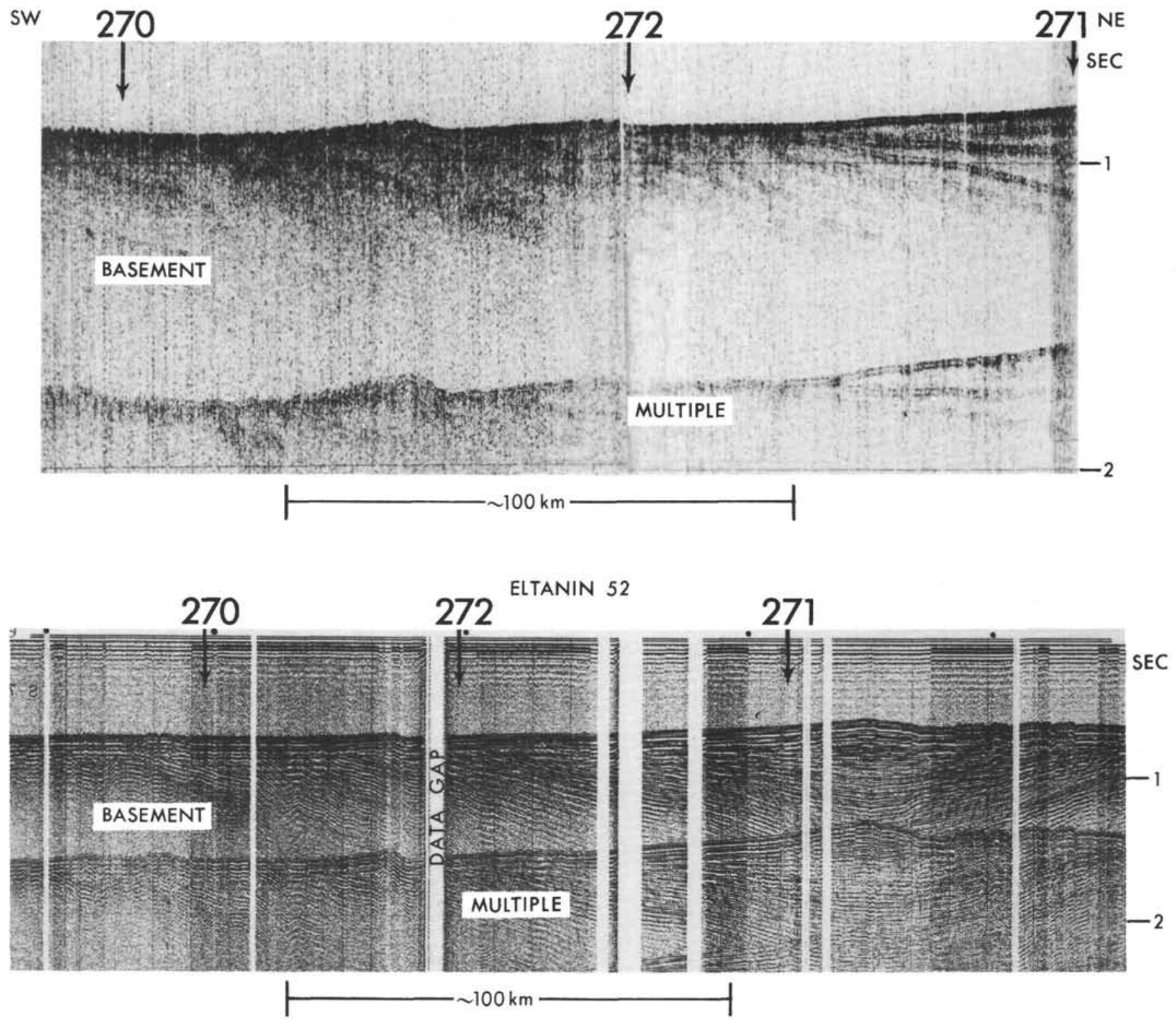

Figure 2. (Upper) Glomar Challenger acoustic reflection profile across Sites 270-272. (Lower) Eltanin 52 profile through same area. Location of profile shown in Figure 1. Vertical scale is in seconds of two-way reflection time.

\section{OPERATIONS, SITE 270}

Site 270 was chosen on the basis of previously acquired (Eltanin 52) geophysical data. The approach to the geographic position of the predetermined site was made from the northwest. The ship crossed the site on a heading of $138^{\circ}$ and the beacon and a spar buoy were dropped at 2158 on 29 January. Geophysical gear was retrieved and the ship reversed course, returned toward the spar buoy, and positioned on beacon. Water depth was 639 meters (corrected PDR). Figure 3 shows the seismic profile obtained during the approach to the site.

While the bottom-hole assembly and drill string were being run, a sonobuoy record was obtained. Despite the presence of considerable reverberation, there appears to be a clear reflecting horizon at about $0.12 \mathrm{sec}$. Although basement was not clearly discernible, it probably lies within the range of $0.35-0.40 \mathrm{sec}$ (two-way travel time). Below this level, coherent returns are no longer observed. Eltanin seismic data (profiler and sonobuoy) show a rather clear "basement" horizon at about 0.40 sec (two-way travel time).

Hole 270 was spudded in at 0130 on 30 January 1973. Continuous coring was carried out to a depth of 422.5 meters subbottom by 2330 on 2 February. A total of 49 cores was taken penetrating 422.5 meters and recovering 263.7 meters for an average recovery of $62 \%$ (see Table 1).

The shallow water and relatively hard sediment from the mud line down, placed stringent requirements on both the positioning system and the coring operations. During the almost $40 \mathrm{hr}$ it took to bury the bottom-hole 


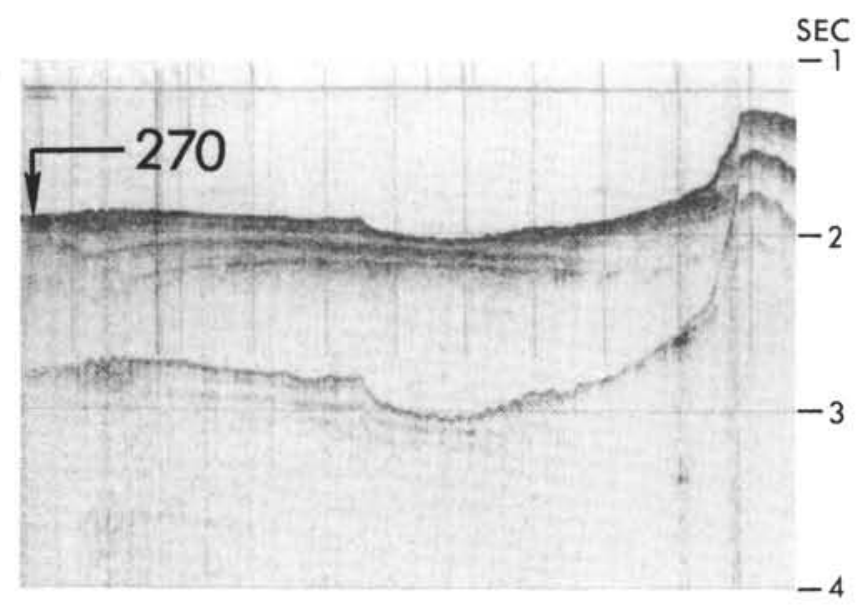

Figure 3. Glomar Challenger acoustic reflection profile on approach to Site 270. For track location see Hayes and Wall, this volume.

assembly with continuous coring, excursions of the ship off the beacon seldom exceeded $20 \mathrm{ft}$. The positioning requirements were maintained even in the face of 40 knot winds and a $7-\mathrm{ft}$ swell on the evening of 1 February. Drilling and coring operations proceeded with no problems except for a short delay caused by frozen air lines to the Bowen powersub controls.

Coring was terminated at 2330 on 2 February and the bit was brought on deck at 0330 on 3 February. After testing the beacon to be used at the next site, the ship got underway at $0355 \mathrm{hr}$.

\section{OPERATIONS, SITE 271}

Site 271 was chosen on the basis of previously acquired (Eltanin 52) geophysical data. Approach to the site was made on a heading of $090^{\circ}$. The beacon and a spar buoy were dropped at 1130 on 3 February 1973. The towed geophysical gear was retrieved, and the ship reversed course, returned toward the spar buoy, and positioned over beacon. Positioning in the automatic mode was acquired by $1200 \mathrm{hr}$. Water depth was 566 meters (PDR corrected).

While the bottom-hole assembly and drill string were being run, a sonobuoy record was obtained. It, together with the profiler record made on approaching the site (Figure 3), indicates the presence of several closely spaced reflecting horizons within the top 40 or 50 meters of sediment and again between 0.14 and $0.16 \mathrm{sec}$ of twoway travel time. The clearest subbottom reflector is found at about $0.30 \mathrm{sec}$ of two-way travel time, and it can be followed up-dip on the profiler records to the southwest where its truncation at or near the surface is reflected in the bottom topography as a small ridge.

Bottom was tagged at 1500 on 3 February and nearly continuous coring was carried out to a depth of 265 meters subbottom. Recovery was variable but generally low for the entire section penetrated (see Table 2).

Because of the poor recovery and the presence of significant trace amounts of gas (methane and ethane) in Core 24 , drilling and coring operations were abandoned. The hole was sealed with two 130-meter plugs of cement over about 10 meters of heavy drilling mud (11.4 lb/gal).
The drill string and bottom-hole assembly were recovered and the ship got underway at 2144 on 5 February.

\section{OPERATIONS, SITE 272}

Site 272 lies along the same northeast-southwest Eltanin 52 seismic profiler line as Sites 270 and 271 and approximately midway between them. Its location on the seismic section (see Figure 3 ) was chosen so that (1) the uppermost sediments penetrated would be stratigraphically lower than the deepest sediments penetrated at Site 271 where hydrocarbons were encountered, (2) a relatively strong and presumably hard subbottom reflector would not be penetrated until the bottom-hole assembly was nearly buried, and (3) the deepest sediments cored would overlap with the shallowest part of the section from Site 270 if a penetration of $>600$ meters was obtained.

The approach to the site was made on a course of $225^{\circ}$. The beacon and a spar buoy were dropped at 0104 on 6 February in 619 meters of water (PDR corrected). Geophysical gear was retrieved, and the ship returned to the spar buoy and began positioning over the beacon. Positioning in the automatic mode was attained by 0200 hr.

Hole 272 was spudded in at 0430 on 6 February and except for the first 4 meters was continuously cored to a total depth of 443 meters subbottom. Recovery, though variable, was satisfactory through Core 33 at 317.5 meters subbottom. Below this level a total of 125.5 meters was cored and only 10.6 meters recovered (see Table 3).

Because of the poor recovery and the presence of gas (methane with traces of ethane), detected whenever adequate samples were obtained, drilling and coring were terminated. The bottom 310 meters of hole were filled with heavy drilling mud $(11.4 \mathrm{lb} / \mathrm{gal})$ and the top 130 meters of hole were sealed with a cement plug.

The bit was brought on deck at 0230 on 9 February, the beacon for use at Site 273 was tested, and the ship got underway at $0320 \mathrm{hr}$. The underway geophysical gear was streamed on a heading of $053^{\circ}$. The ship then reversed course and ran a final seismic line between Sites 270 and 272.

\section{LITHOLOGY}

\section{Site $\mathbf{2 7 0}$}

Hole 270 penetrated a sedimentary sequence 412 meters thick and terminated 10.5 meters into a basement of foliated marble of possible early Paleozoic age. Five distinctive sedimentary units overlie the basement terrane (Table 4). Units 1 and 2 are of marine glacial origin. Units 3 and 4 are of shallow marine or nearshore origin, but show no evidence of glacial influence. Unit 5 is a sedimentary breccia of basement lithologies.

Paleontological dating of Site 270 is poor, but two other methods have been applied with some success. K$\mathrm{Ar}$ dating of the greensand immediately beneath the glacial sequence has given an age of $26.0 \mathrm{~m}$.y. In addition, a paleomagnetic stratigraphy has been reasonably well established for the upper part of Unit 2 (from 16.7 
TABLE 1

Coring Summary, Site 270

\begin{tabular}{|c|c|c|c|c|c|c|c|}
\hline Core & $\begin{array}{c}\text { Date } \\
\text { (Jan. and } \\
\text { Feb. 1973) }\end{array}$ & Time & $\begin{array}{l}\text { Depth From } \\
\text { Drill Floor } \\
\text { (m) }\end{array}$ & $\begin{array}{l}\text { Depth Below } \\
\text { Sea Floor } \\
\text { (m) }\end{array}$ & $\begin{array}{l}\text { Length } \\
\text { Cored } \\
\text { (m) }\end{array}$ & $\begin{array}{c}\text { Length } \\
\text { Recovered } \\
\text { (m) }\end{array}$ & $\begin{array}{c}\text { Recovery } \\
(\%)\end{array}$ \\
\hline 1 & 30 & 0230 & $644.0-650.0$ & $0.0-6.0$ & 6.0 & 2.3 & 38 \\
\hline 2 & 30 & 0500 & $650.0-659.5$ & $6.0-15.5$ & 9.5 & $\mathrm{CC}$ & - \\
\hline 3 & 30 & 0815 & $659.5-669.0$ & $15.5-25.0$ & 9.5 & 0.5 & 5 \\
\hline 4 & 30 & 1015 & $669.0-669.5$ & $25.0-25.5$ & 0.5 & $\mathrm{CC}$ & - \\
\hline 5 & 30 & 1243 & $669.5-678.5$ & $25.5-34.5$ & 9.0 & 1.7 & 20 \\
\hline 6 & 30 & 1602 & $678.5-688.0$ & $34.5-44.0$ & 9.5 & 2.7 & 28 \\
\hline 7 & 30 & 1925 & $688.0-697.5$ & $44.0-53.5$ & 9.5 & 3.6 & 38 \\
\hline 8 & 30 & 2224 & $697.5-707.0$ & $53.5-63.0$ & 9.5 & 4.0 & 42 \\
\hline 9 & 31 & 0220 & $707.0-716.5$ & $63.0-72.5$ & 9.5 & 3.4 & 36 \\
\hline 10 & 31 & 0515 & $716.5-726.0$ & $72.5-82.0$ & 9.5 & 2.4 & 25 \\
\hline 11 & 31 & 0732 & $726.0-735.5$ & $82.0-91.5$ & 9.5 & 2.5 & 26 \\
\hline 12 & 31 & 1000 & $735.5-745.0$ & $91.5-101.0$ & 9.5 & 6.0 & 63 \\
\hline 13 & 31 & 1235 & $745.0-754.5$ & $101.0-110.5$ & 9.5 & 3.9 & 41 \\
\hline 14 & 31 & 1424 & $754.5-764.0$ & $110.5-120.0$ & 9.5 & 4.5 & 47 \\
\hline 15 & 31 & 1539 & $764.0-773.5$ & $120.0-129.5$ & 9.5 & 4.6 & 48 \\
\hline 16 & 31 & 1747 & $773.5-783.0$ & $129.5-139.0$ & 9.5 & 4.7 & 49 \\
\hline 17 & 31 & 2003 & $783.0-792.5$ & $139.0-148.5$ & 9.5 & 6.9 & 73 \\
\hline 18 & 31 & 2112 & $792.5-802.0$ & $148.5-158.0$ & 9.5 & 6.9 & 73 \\
\hline 19 & 31 & 2215 & $802.0-811.5$ & $158.0-167.5$ & 9.5 & 7.4 & 78 \\
\hline 20 & 31 & 2305 & $811.5-821.0$ & $167.5-177.0$ & 9.5 & 8.2 & 86 \\
\hline 21 & 31 & 2359 & $821.0-830.5$ & $177.0-186.5$ & 9.5 & 6.8 & 72 \\
\hline 22 & Feb. 1 & 0102 & $830.5-840.0$ & $186.5-196.0$ & 9.5 & 9.5 & 100 \\
\hline 23 & 1 & 0151 & $840.0-849.5$ & $196.0-205.5$ & 9.5 & 5.3 & 56 \\
\hline 24 & 1 & 0235 & $849.5-859.0$ & $205.5-215.0$ & 9.5 & 3.8 & 40 \\
\hline 25 & 1 & 0330 & $859.0-868.5$ & $215.0-224.5$ & 9.5 & 5.8 & 61 \\
\hline 26 & 1 & 0440 & $868.5-878.0$ & $224.5-234.0$ & 9.5 & 7.9 & 83 \\
\hline 27 & 1 & 0600 & $878.0-887.5$ & $234.0-243.5$ & 9.5 & 7.4 & 77 \\
\hline 28 & 1 & 0752 & $887.5-897.0$ & $243.5-253.0$ & 9.5 & 9.5 & 100 \\
\hline 29 & 1 & 0920 & $897.0-906.5$ & $253.0-262.5$ & 9.5 & 9.0 & 95 \\
\hline 30 & 1 & 1035 & $906.5-916.0$ & $262.5-272.0$ & 9.5 & 7.5 & 79 \\
\hline 31 & 1 & 1208 & $916.0-925.5$ & $272.0-281.5$ & 9.5 & 7.8 & 82 \\
\hline 32 & 1 & 1350 & $925.5-935.0$ & $281.5-291.0$ & 9.5 & 7.0 & 74 \\
\hline 33 & 1 & 1515 & $935.0-944.5$ & $291.0-300.5$ & 9.5 & 8.5 & 89 \\
\hline 34 & 1 & 1653 & $944.5-954.0$ & $300.5-310.0$ & 9.5 & 8.0 & 84 \\
\hline 35 & 1 & 1840 & $954.0-963.5$ & $310.0-319.5$ & 9.5 & 9.5 & 100 \\
\hline 36 & 1 & 1955 & $963.5-973.0$ & $319.5-329.0$ & 9.5 & 8.5 & 89 \\
\hline 37 & 1 & 2145 & $973.0-982.5$ & $329.0-338.5$ & 9.5 & 5.1 & 54 \\
\hline 38 & 1 & 2300 & $982.5-992.0$ & $338.5-348.0$ & 9.5 & 8.9 & 94 \\
\hline 39 & 2 & 0034 & $992.0-1001.5$ & $348.0-357.5$ & 9.5 & 8.8 & 93 \\
\hline 40 & 2 & 0200 & $1001.5-1011.0$ & $357.5-367.0$ & 9.5 & 7.0 & 74 \\
\hline 41 & 2 & 0415 & $1011.0-1014.0$ & $367.0-370.0$ & 3.0 & 3.3 & $100+$ \\
\hline 42 & 2 & 0530 & $1014.0-1020.5$ & $370.0-376.5$ & 6.5 & 6.0 & 92 \\
\hline 43 & 2 & 0750 & $1020.5-1030.0$ & $376.5-386.0$ & 9.5 & 7.9 & 83 \\
\hline 44 & 2 & 0930 & $1030.0-1039.5$ & $386.0-395.5$ & 9.5 & 6.5 & 68 \\
\hline 45 & 2 & 1125 & $1039.5-1049.0$ & $395.5-405.0$ & 9.5 & 5.3 & 56 \\
\hline 46 & 2 & 1400 & $1049.0-1053.5$ & $405.0-409.5$ & 4.5 & 2.0 & 44 \\
\hline 47 & 2 & 1750 & $1053.5-1058.5$ & $409.5-414.5$ & 5.0 & 3.3 & 66 \\
\hline 48 & 2 & 2111 & $1058.5-1065.5$ & $414.5-421.5$ & 7.0 & 1.0 & 14 \\
\hline 49 & 2 & 2330 & $1065.5-1066.5$ & $421.5-422.5$ & 1.0 & 0.6 & 60 \\
\hline Total & & & & & 422.5 & 263.7 & 62 \\
\hline
\end{tabular}

to $20.7 \mathrm{~m} . \mathrm{y}$.) and can be extended to the base of the hole with somewhat less confidence (Allis et al., this volume). Nevertheless, the inferred paleomagnetic age of the older glacial beds ( 25.0 or 25.5 m.y.) is consistent with the age of the underlying greensand.

A number of other aspects of the core from Site 270 have been studied in detail and presented in later chapters: (1) Mollusks from Unit 2 by Dell and Fleming (this volume), (2) textural characteristics of both glacial and preglacial sediments by Barrett (this volume), (3) Oligocene microflora by Kemp (this volume), (4) Basement rocks by Ford and Barrett (this volume).

\section{Unit 1}

Unit 1 comprises 20 meters of soft light olive-gray to dark greenish-gray sediment. The upper $20 \mathrm{~cm}$ (Subunit IA) is soupy to soft and has a high proportion of diatoms $(40 \%)$ with very little sand. It has a sharp contact with the underlying soft to stiff sand-silt-clay (Subunit 1B) most of which contains only $2 \%-5 \%$ diatoms. No pebbles were found in Subunit 1A, but granules and pebbles up to at least $6 \mathrm{~cm}$ long are evenly distributed throughout $1 \mathrm{~B}$ and form about $1 \%$ of the sediment. The largest clast encountered may have been 
TABLE 2

Coring Summary, Site 271

\begin{tabular}{|c|c|c|c|c|c|c|c|}
\hline Core & $\begin{array}{l}\text { Date } \\
\text { (Feb. } \\
\text { 1973) }\end{array}$ & Time & $\begin{array}{l}\text { Depth From } \\
\text { Drill Floor } \\
\text { (m) }\end{array}$ & $\begin{array}{l}\text { Depth Below } \\
\text { Sea Floor } \\
\text { (m) }\end{array}$ & $\begin{array}{l}\text { Length } \\
\text { Cored } \\
\text { (m) }\end{array}$ & $\begin{array}{l}\text { Length } \\
\text { Recovered } \\
\text { (m) }\end{array}$ & $\begin{array}{c}\text { Recovery } \\
(\%)\end{array}$ \\
\hline 1 & 3 & 2110 & $585.0-594.5$ & $21.0-30.5$ & 9.5 & 1.5 & 16 \\
\hline 2 & 3 & 2325 & $614.0-623.5$ & $40.0-49.5$ & 9.5 & 0.5 & 5 \\
\hline 3 & 4 & 0027 & $623.5-633.0$ & $49.5-59.0$ & 9.5 & 2.5 & 26 \\
\hline 4 & 4 & 0230 & $633.0-642.5$ & $59.0-68.5$ & 9.5 & 0.7 & 7 \\
\hline 5 & 4 & 0405 & $642.5-652.0$ & $68.5-78.0$ & 9.5 & 5.4 & 57 \\
\hline 6 & 4 & 0630 & $652.0-661.5$ & $78.0-87.5$ & 9.5 & $\mathrm{CC}$ & - \\
\hline 7 & 4 & 0840 & $661.5-671.0$ & $87.5-97.0$ & 9.5 & $\mathrm{CC}$ & - \\
\hline 8 & 4 & 0940 & $671.0-680.5$ & $97.0-106.5$ & 9.5 & - & - \\
\hline 9 & 4 & 1120 & $680.5-690.0$ & $106.5-116.0$ & 9.5 & $\mathrm{CC}$ & - \\
\hline 10 & 4 & 1145 & $690.0-699.5$ & $116.0-125.5$ & 9.5 & - & - \\
\hline 11 & 4 & 1230 & $699.5-706.0$ & $125.5-132.0$ & 6.5 & - & - \\
\hline 12 & 4 & 1445 & $709.0-718.5$ & $135.0-144.5$ & 9.5 & 0.4 & 4 \\
\hline 13 & 4 & 1542 & $718.5-728.0$ & $144.5-154.0$ & 9.5 & 0.5 & 5 \\
\hline 14 & 4 & 1710 & $728.0-737.5$ & $154.0-163.5$ & 9.5 & $\mathrm{CC}$ & - \\
\hline 15 & 4 & 1927 & $739.5-749.0$ & $165.5-175.0$ & 9.5 & $\mathrm{CC}$ & - \\
\hline 16 & 4 & 2017 & $749.0-758.5$ & $175.0-184.5$ & 9.5 & $\mathrm{CC}$ & - \\
\hline 17 & 4 & 2130 & $758.5-768.0$ & $184.5-194.0$ & 9.5 & - & - \\
\hline 18 & 4 & 2335 & $770.0-778.0$ & $196.0-204.0$ & 8.0 & - & - \\
\hline 19 & 5 & 0140 & $778.0-787.0$ & $204.0-213.0$ & 9.0 & 1.6 & 17 \\
\hline 20 & 5 & 0320 & $787.0-796.5$ & $213.0-222.5$ & 9.5 & 0.3 & 3 \\
\hline 21 & 5 & 0420 & $796.5-806.0$ & $222.5-232.0$ & 9.5 & $\mathrm{CC}$ & - \\
\hline 22 & 5 & 0535 & $806.0-815.5$ & $232.0-241.5$ & 9.5 & 0.2 & 2 \\
\hline 23 & 5 & 0710 & $815.5-825.0$ & $241.5-251.0$ & 9.5 & $\mathrm{CC}$ & - \\
\hline 24 & 5 & 1137 & $829.5-839.0$ & $255.5-265.0$ & 9.5 & 1.7 & 17 \\
\hline Total & & & & & 233.0 & 15.3 & 7 \\
\hline
\end{tabular}

larger than the bit diameter $(20 \mathrm{~cm})$, because the drilling rate was substantially slower for a part of Core 2 .

The sand and silt fractions in Unit 1 at Site 270 consist of angular quartz and feldspar in subequal amounts, and a variety of heavy minerals, including zircon (with some hyacinth), hornblende, pyroxene, and biotite.

Unit 1 at Sites 272 and 273 has been subdivided similarly, and the Subunits A and B at all three sites seem lithologically equivalent. Micropaleontological study has not yet revealed whether the subunits span the same periods of time.

\section{Unit 2}

The contact between Units 1 and 2, between 16.5 and 25 meters subbottom, is marked by a considerable increase in lithification and a sudden drop in diatom content. The contact is believed to be the angular unconformity seen on the profiler record (Figure 4).

The sediments of Unit 2 are mainly poorly sorted silty claystone with from $1 \%$ to $20 \%$ sand (Figure 5), though three intervals of about 10 meters have a sand content between $15 \%$ and $35 \%$. Granules and pebbles are widespread, and there are no pebble-free intervals of more than 2 or 3 meters throughout the entire unit, though typically only $0.1 \%-1 \%$ of the rock is made up of granules and larger clasts. Clasts longer than $3 \mathrm{~cm}$ are rare, but several from 6 to $10 \mathrm{~cm}$ long were recovered.

Cores from the upper part of Unit 2 appear significantly harder than cores lower in the unit. This lithification is attributed to cementation by cristobalite, which figures prominently in quantitative X-ray analyses for this interval but not below (Appendix III). The source of the cristobalite is almost certainly opaline silica from diatoms, which may have formed as much as
$30 \%$ of the rock, judging from the amount of cristobalite. Experimental evidence by Greenwood (1973) has confirmed earlier hypotheses that during diagenesis of noncalcareous sediments solution of biogenic silica is followed by precipitation of poorly ordered cristobalite. Cristobalite also occurs in similar rocks of middle-Miocene age near the base of Site 272, and in porcellaneous cherts of Miocene and Oligocene age at Sites 268, 269, and 274.

Unit 2 has been subdivided into 10 subunits, which are grouped into three lithofacies, on the basis of bedding features and clast distribution (Table 5). The "unstratified" lithofacies is characterized by evenly distributed granules and pebbles that form an estimated $0.5 \%$ of the rock, and by a lack of bedding, though all three subunits of this facies have one or two thin indistinctly laminated intervals. The uniformity of lithology and the poor sorting nevertheless suggest a stable sedimentary environment and a virtual absence of bottom currents. The poor sorting, large range of clast size, and variety of bed rock lithologies clearly indicate deposition from ice.

The "fine stratified" facies is characterized by a variable but low clast density (Table 5), dominance of silty claystone and claystone, and by wavy and plane parallel lamination. Some lamination is evident only from color differences, but the lamination that is present throughout Subunit E is clearly due to alternating siltand clay-rich layers. The cause of the former is not known, but the latter undoubtedly results from traction currents.

The "coarse stratified" facies consists mainly of poorly sorted, sandy clayey siltstone, though beds of silty claystone up to 1 meter thick are common in some inter- 
TABLE 3

Coring Summary, Site 272

\begin{tabular}{|c|c|c|c|c|c|c|c|}
\hline Core & $\begin{array}{l}\text { Date } \\
\text { (Feb. } \\
\text { 1973) }\end{array}$ & Time & $\begin{array}{l}\text { Depth From } \\
\text { Drill Floor } \\
\text { (m) }\end{array}$ & $\begin{array}{l}\text { Depth Below } \\
\text { Sea Floor } \\
\text { (m) }\end{array}$ & $\begin{array}{l}\text { Length } \\
\text { Cored } \\
\text { (m) }\end{array}$ & $\begin{array}{l}\text { Length } \\
\text { Recovered } \\
\text { (m) }\end{array}$ & $\begin{array}{c}\text { Recovery } \\
(\%)\end{array}$ \\
\hline 1 & 6 & 0526 & $633.0-642.5$ & $4.0-13.5$ & 9.5 & 7.0 & 74 \\
\hline 2 & 6 & 0702 & $642.5-652.0$ & $13.5-23.0$ & 9.5 & 6.5 & 68 \\
\hline 3 & 6 & 0823 & $652.0-661.5$ & $23.0-32.5$ & 9.5 & 5.7 & 60 \\
\hline 4 & 6 & 0917 & $661.5-671.0$ & $32.5-42.0$ & 9.5 & 6.5 & 68 \\
\hline 5 & 6 & 1020 & $671.0-680.5$ & $42.0-51.5$ & 9.5 & 3.7 & 39 \\
\hline 6 & 6 & 1120 & $680.5-690.0$ & $51.5-61.0$ & 9.5 & 5.4 & 56 \\
\hline 7 & 6 & 1220 & $690.0-699.5$ & $61.0-70.5$ & 9.5 & 1.9 & 19 \\
\hline 8 & 6 & 1402 & $699.5-709.0$ & $70.5-80.0$ & 9.5 & 6.0 & 63 \\
\hline 9 & 6 & 1635 & $709.0-718.5$ & $80.0-89.5$ & 9.5 & 5.2 & 54 \\
\hline 10 & 6 & 1810 & $718.5-728.0$ & $89.5-99.0$ & 9.5 & 7.5 & 79 \\
\hline 11 & 6 & 1928 & $728.0-737.5$ & $99.0-108.5$ & 9.5 & 7.5 & 79 \\
\hline 12 & 6 & 2100 & $737.5-747.0$ & $108.5-118.0$ & 9.5 & 2.6 & 27 \\
\hline 13 & 6 & 2228 & $747.0-756.5$ & $118.0-127.5$ & 9.5 & 4.4 & 46 \\
\hline 14 & 7 & 0050 & $756.5-766.0$ & $127.5-137.0$ & 9.5 & 6.0 & 63 \\
\hline 15 & 7 & 0150 & $766.0-775.5$ & $137.0-146.5$ & 9.5 & 2.1 & 22 \\
\hline 16 & 7 & 0255 & $775.5-785.0$ & $146.5-156.0$ & 9.5 & 3.7 & 39 \\
\hline 17 & 7 & 0410 & $785.0-794.5$ & $156.0-165.5$ & 9.5 & 3.6 & 37 \\
\hline 18 & 7 & 0500 & $794.5-804.0$ & $165.5-175.0$ & 9.5 & 2.9 & 30 \\
\hline 19 & 7 & 0550 & $804.0-813.5$ & $175.0-184.5$ & 9.5 & 7.7 & 81 \\
\hline 20 & 7 & 0700 & $813.5-823.0$ & $184.5-194.0$ & 9.5 & $\mathrm{CC}$ & - \\
\hline 21 & 7 & 0810 & $823.0-832.5$ & $194.0-203.5$ & 9.5 & 6.3 & 66 \\
\hline 22 & 7 & 0900 & $832.5-842.0$ & $203.5-213.0$ & 9.5 & 9.5 & 100 \\
\hline 23 & 7 & 1015 & $842.0-851.5$ & $213.0-222.5$ & 9.5 & 5.3 & 55 \\
\hline 24 & 7 & 1110 & $851.5-861.0$ & $222.5-232.0$ & 9.5 & 2.7 & 28 \\
\hline 25 & 7 & 1207 & $861.0-870.5$ & $232.0-241.5$ & 9.5 & 5.3 & 55 \\
\hline 26 & 7 & 1305 & $870.5-880.0$ & $241.5-251.0$ & 9.5 & 0.2 & 2 \\
\hline 27 & 7 & 1402 & $880.0-889.5$ & $251.0-260.5$ & 9.5 & 4.5 & 47 \\
\hline 28 & 7 & 1513 & $889.5-899.0$ & $260.5-270.0$ & 9.5 & 1.9 & 19 \\
\hline 29 & 7 & 1615 & $899.0-908.5$ & $270.0-279.5$ & 9.5 & 7.5 & 79 \\
\hline 30 & 7 & 1715 & $908.5-918.0$ & $279.5-289.0$ & 9.5 & 2.2 & 23 \\
\hline 31 & 7 & 1810 & $918.0-927.5$ & $289.0-298.5$ & 9.5 & 3.0 & 31 \\
\hline 32 & 7 & 1910 & $927.5-937.0$ & $298.5-308.0$ & 9.5 & 3.2 & 33 \\
\hline 33 & 7 & 2015 & $937.0-946.5$ & $308.0-317.5$ & 9.5 & 3.9 & 41 \\
\hline 34 & 7 & 2330 & $946.5-956.0$ & $317.5-327.0$ & 9.5 & 0.8 & 8 \\
\hline 35 & 8 & 0050 & $956.0-965.5$ & $327.0-336.5$ & 9.5 & 0.3 & 3 \\
\hline 36 & 8 & 0210 & $965.5-975.0$ & $336.5-346.0$ & 9.5 & 0.0 & - \\
\hline 37 & 8 & 0350 & $975.0-984.5$ & $346.0-355.5$ & 9.5 & 4.0 & 42 \\
\hline 38 & 8 & 0515 & $984.5-994.0$ & $355.5-365.5$ & 9.5 & 2.1 & 22 \\
\hline 39 & 8 & 0615 & $994.0-1003.5$ & $365.0-374.5$ & 9.5 & 1.4 & 14 \\
\hline 40 & 8 & 0745 & $1003.5-1013.0$ & $374.5-384.0$ & 9.5 & $\mathrm{CC}$ & - \\
\hline 41 & 8 & 0905 & $1013.5-1022.5$ & $384.0-393.5$ & 9.5 & 1.0 & 10 \\
\hline 42 & 8 & 1030 & $1022.5-1032.0$ & $393.5-403.0$ & 9.5 & 1.0 & 10 \\
\hline 43 & 8 & 1150 & $1032.0-1041.5$ & $403.0-412.5$ & 9.5 & $\mathrm{CC}$ & - \\
\hline 44 & 8 & 1320 & $1041.5-1052.0$ & $412.5-422.0$ & 9.5 & $\mathrm{CC}$ & - \\
\hline 45 & 8 & 1420 & $1051.0-1060.5$ & $422.0-431.5$ & 9.5 & $\mathrm{CC}$ & - \\
\hline 46 & 8 & 1550 & $1060.5-1063.0$ & $431.5-434.0$ & 2.5 & $\mathrm{CC}$ & - \\
\hline 47 & 8 & 1735 & $1063.0-1070.0$ & $434.0-441.0$ & 7.0 & $\mathrm{CC}$ & - \\
\hline 48 & 8 & 1845 & $1070.0-1072.0$ & $441.0-443.0$ & 2.0 & 0.0 & - \\
\hline Total & & & & & 439.0 & 162.0 & 37 \\
\hline
\end{tabular}

vals. Bedding is most obvious from the presence of coarse sandy beds 10 to $50 \mathrm{~cm}$ thick separated by thicker intervals of clayey siltstone, though it can be seen also from grain-size variations within the thicker sandy siltstone intervals. Concentrations of granules and pebbles, some of which form as much as $7 \%$ of the rock for intervals of 10 or $20 \mathrm{~cm}$, also clearly define a stratification. Some, but not all, of the thin coarse sandy beds show a gradation in grain size down to a sharp contact, which in several cases overlies a clayey siltstone with bulbous sand lenses. These are interpreted as load casts that developed to a point where they became completely enveloped by the siltstone and "necked off." The sand beds themselves may have resulted from turbidity current deposition. However, other similar sand beds can be seen to grade upward and downward into siltstone.

In two of the four subunits, $2 \mathrm{H}$ and $2 \mathrm{~F}$, stratification and fractures that parallel stratification dip at $20^{\circ}$ to $50^{\circ}$ over intervals of 23 and 10 meters, respectively. The dips are believed to be the result of mass movement soon after deposition of the sediments. Some intervals of horizontal bedding can be seen within the sequence of dipping beds, suggesting that either several movements are represented or that the beds separated into several packets of strata during a single deformational event.

Both stratified facies have intervals of undeformed core with deformed sedimentary fragments similar in 
TABLE 4

Lithologic Units, Site 270

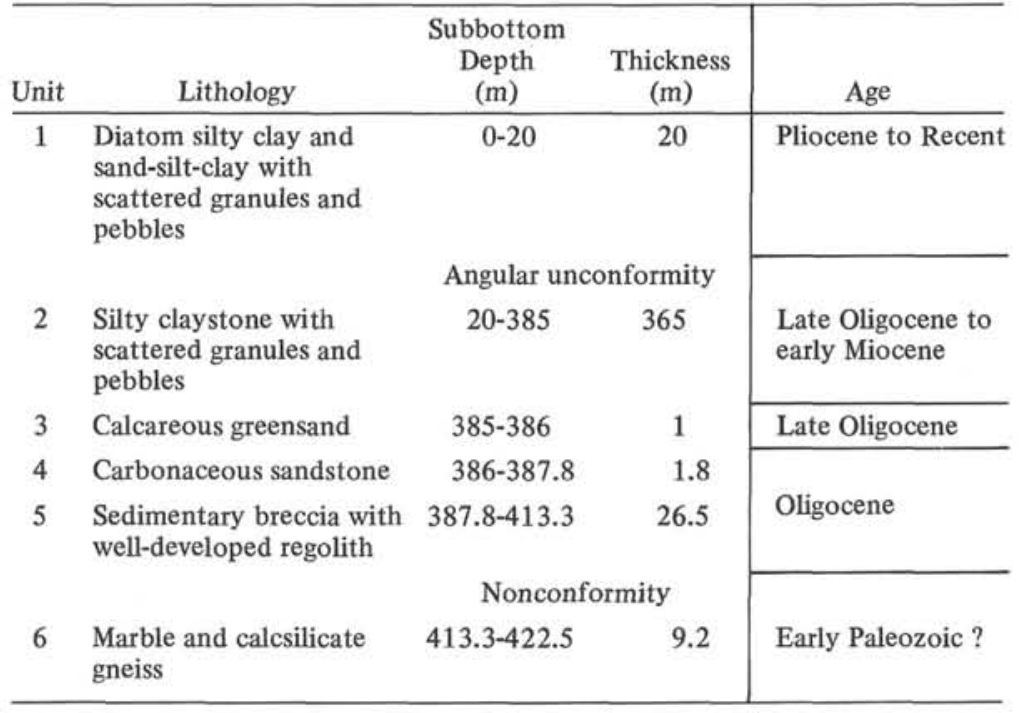

SW
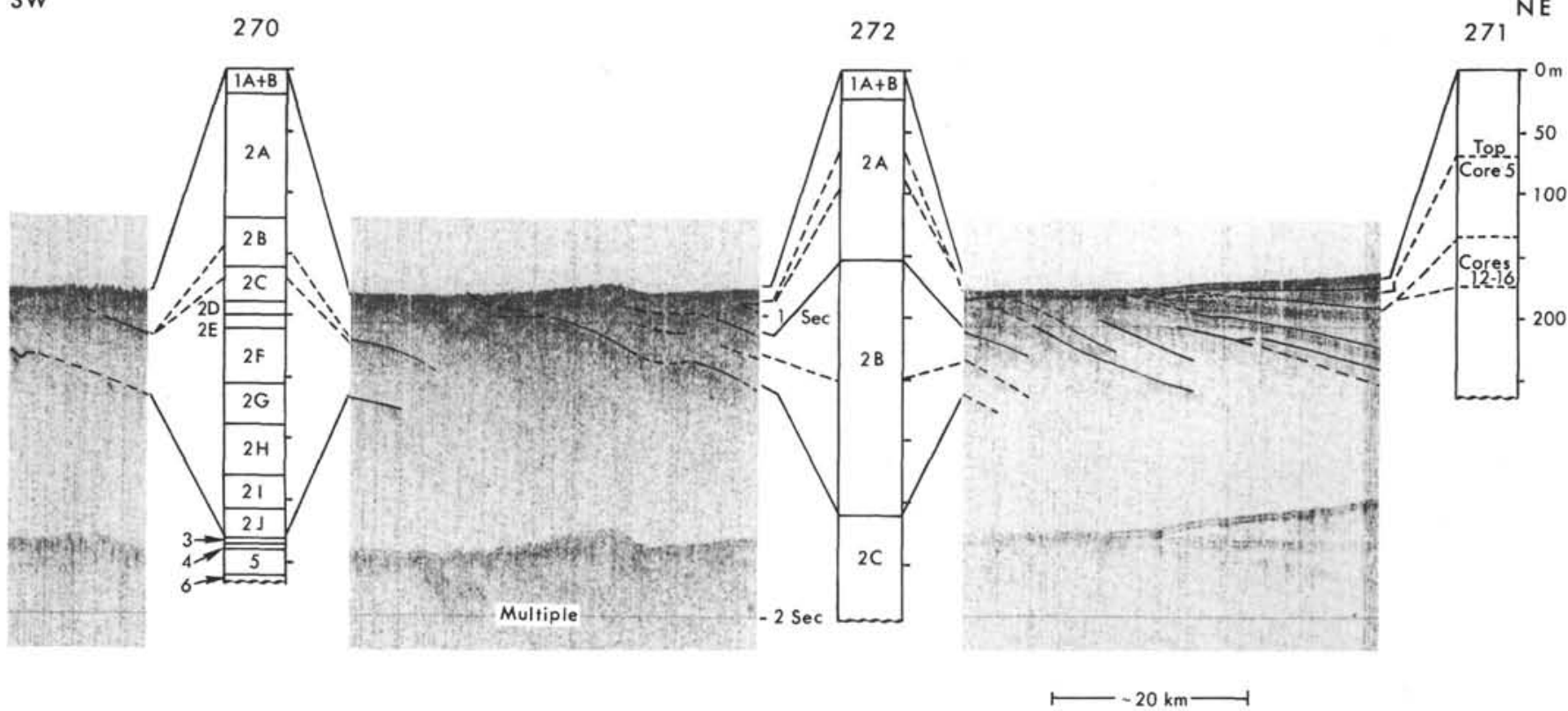

Figure 4. Comparison of seismic profiles and drilled sections at Sites 270-272. See text for explanation of lithologic units.

lithology but slightly different in color from the enclosing sediment. They are mostly 2 to $4 \mathrm{~cm}$ across and less than $1 \mathrm{~cm}$ thick, and oriented subparallel to bedding. However, in a few cases, such as in Core 28 beneath the dipping beds, some are oriented vertically and are as much as $10 \mathrm{~cm}$ long. Similar soft sediment clasts are common in fine-grained glacial sediments in Unit 2 at Site 272 . The clasts are believed to come from the tearing apart of more lithified layers as a result of slumping soon after deposition. The cause of the slumping is unknown.

Burrows were also found in both facies but are common only in Subunit J. One type of burrow is 2 to $4 \mathrm{~mm}$ wide and occurs in the plane of the bedding. The other type, which was seen overlying Subunit J, varies from 10 to $30 \mathrm{~mm}$ wide and may be oriented horizontally or vertically. Some are as long as $15 \mathrm{~cm}$. In longitudinal section laminae within the burrows are transverse in the middle and tangential at the burrow margins ("Meniscus" structure).

Fine crystalline calcium carbonate occurs as cement or as limestone beds up to $90 \mathrm{~cm}$ at two or three places in most subunits. The carbonate may constitute as much as $55 \%$ of the rock, even though the carbonate-rich area appears little different from the adjacent noncarbonate rock. Both sharp contacts and contacts gradational over several centimeters were seen. The carbonate in the lower three subunits has a more widespread and patchy 


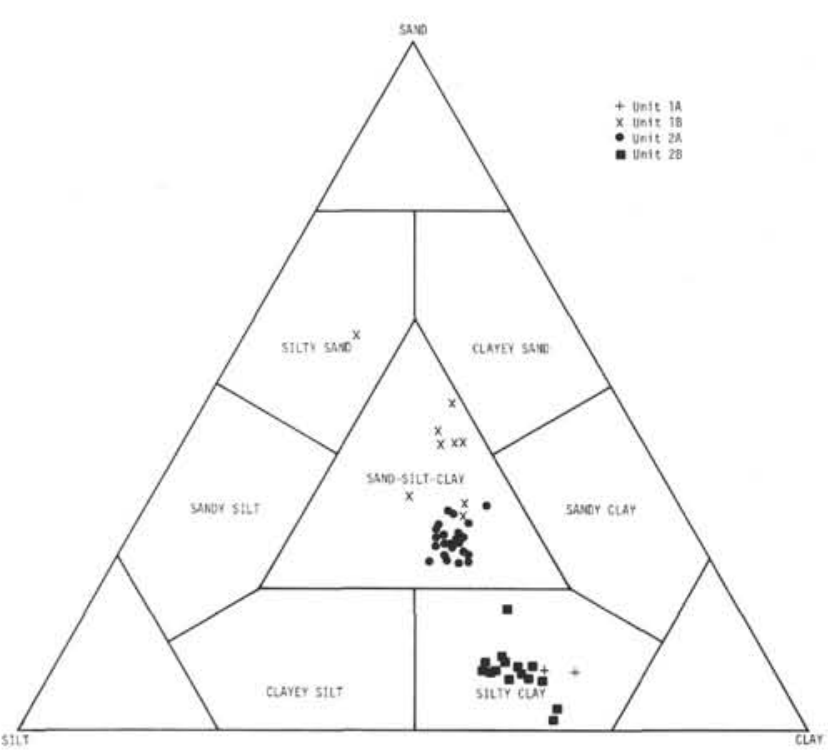

Figure 5. Textural composition of sediments at Site 270.

distribution. It forms scattered irregularly shaped bodies typically 5 to $10 \mathrm{~cm}$ across that clearly cut across bedding features. The carbonate patches vary considerably in carbonate content within themselves, but are a little harder and show local sedimentary structures more clearly than the adjacent noncarbonate sediment.

The sand and silt fractions in Unit 2 are chiefly angular to subangular quartz and feldspar in subequal proportions throughout, but there appear to be two clearly defined changes in heavy mineralogy. Hornblende appears in Core 36 and is consistently present to the top of the unit, whereas tourmaline in several colors is found from the base of the unit to Core 27. Brown biotite and zircon occur throughout the unit.

Mollusc shells, mainly bivalves, occur in every core above 333 meters subbottom, and in several cores below this. Most are shell fragments 0.1 to $0.3 \mathrm{~mm}$ thick, but shells $1 \mathrm{~mm}$ thick were also seen. A number of complete valves and a few gastropods were recovered almost complete. Two bivalve shells are filled with a clayey light- colored matrix, and several gastropods are filled with sand, indicating that they had been reworked. Biogenic material is scarce in smear slides also, but small numbers of coccoliths are consistently present from Cores 28 up to 17 , and diatom fragments from Cores 23 to 16 . Two thin sections from Cores 6 and 7 show several percent of diatoms. Plant fragments were recognized in four widely separated cores.

The abundance of biogenic silica, probably from diatoms, as indicated by the cristobalite, in Subunit 2A, suggests that during deposition the sea was ice free at least part of the year. This would preclude deposition of Subunit 2A from bottom melting of an extended Ross ice shelf. Therefore, it is believed that deposition was from sediment-laden bergs from glaciers and ice-tongues calving directly into the Ross embayment.

\section{Unit 3}

Unit 3, a calcareous greensand, is composed of sand, silt, clay, carbonate, and glauconite in roughly equal proportions. The change in lithology from Unit 2 is most obvious from the striking color change to bluishgreen. The upper contact is not preserved, for it lies between two adjacent blocks in Core 43, Section 6 . However, it is likely that no more than a few centimeters are missing, for a burrow $2 \mathrm{~cm}$ above the basal block of Unit 2 is filled with a glauconite-bearing clayey siltstone. The lack of glauconite in the immediately overlying surrounding basal sediments of Unit 2 suggests that the greensand was consolidated prior to their deposition, but the age difference is small. There is some indistinct horizontal lamination, and a more intensely colored interval of finer grain size from Sample 43-6, 124-137 cm. This interval is penetrated by two vertical tubes, probably burrows, about $10 \mathrm{~mm}$ wide and $5 \mathrm{~cm}$ long, filled with coarser sediment.

\section{Unit 4}

The upper contact of Unit 4 lies in the interval between Cores 43 and 44 . The unit is mainly a friable light gray poorly sorted silty sand with common thin fissile clay laminae. Several bedding surfaces are covered

TABLE 5

Lithofacies for the 10 Subunits of Unit 2

\begin{tabular}{|c|c|c|c|c|}
\hline Lithofacies & $\begin{array}{l}\text { Pebble } \\
\text { Density } \\
\text { (Range) }\end{array}$ & $\begin{array}{l}\text { Longest } \\
\text { Clast } \\
\text { (mm) }\end{array}$ & $\begin{array}{l}\text { Subunits } \\
\text { Thickness } \\
\text { (m) }\end{array}$ & Type of Deposition \\
\hline Unstratified & $3-7$ & $\begin{array}{r}37 \\
48 \\
100\end{array}$ & $\begin{array}{ll}\mathrm{A} & (101) \\
\mathrm{G} & (31) \\
\mathrm{I} & (19)\end{array}$ & $\begin{array}{l}\text { Debris deposited } \\
\text { from ice; no reworking }\end{array}$ \\
\hline Fine stratified & $1-2$ & $\begin{array}{l}19 \\
28 \\
22\end{array}$ & $\begin{array}{ll}\mathrm{B} & (30) \\
\mathrm{D} & (24) \\
\mathrm{E} & (12)\end{array}$ & $\begin{array}{l}\text { Debris transported by } \\
\text { ice; local reworking by } \\
\text { bottom currents }\end{array}$ \\
\hline Coarse stratified & $1-20$ & $\begin{array}{r}20 \\
45 \\
100 \\
35\end{array}$ & $\begin{array}{ll}\mathrm{C} & (26) \\
\mathrm{F} & (44) \\
\mathrm{H} & (46) \\
\mathrm{J} & (26)\end{array}$ & $\begin{array}{l}\text { Debris transported by } \\
\text { ice and currents; } \\
\text { possibly some of tur- } \\
\text { bidity current origin; } \\
\text { local reworking by } \\
\text { bottom currents }\end{array}$ \\
\hline
\end{tabular}

Note: Pebble density is measured as clasts longer than $4 \mathrm{~mm}$ per meter of core length. 
with a brownish-gray to brownish-black film that contains microscopic woody fragments. The sand fraction is almost entirely angular quartz, with some grains showing small solution embayments. About $25 \mathrm{~cm}$ above the base there is a gradation down into a less friable homogeneous poorly sorted medium-grained quartz sand with abundant carbonate, possibly leached from the more friable sand above prior to deposition of the overlying calcareous greensand.

\section{Unit 5}

Unit 5 is a coarse breccia of metamorphic and granitic fragments in chaotic array. The upper 3 meters, which is extensively altered and grades down into unaltered breccia, is interpreted as a buried regolith. The contact with Unit 4 is sharp.

Through most of the unit there are no obvious trends in clast size or composition. The clasts range in size from a few millimeters to at least $50 \mathrm{~cm}$, though most are less than $10 \mathrm{~cm}$ long. Preferred orientation and size sorting was found only in four widely separated sandy and pebbly intervals in Cores 44 and 45 . The intervals are from 10 to $60 \mathrm{~cm}$ thick and dip between $10^{\circ}$ and $30^{\circ}$. Almost all of the clasts are angular, but one or two are rounded. Most are light and dark gray calcsilicate gneiss and foliated marble make up about three-fourths of the clasts, though biotite- and hornblende-bearing leucogranite, garnet-bearing leucogneiss and vein quartz are also present. They are set in a dark greenish-gray carbonate-bearing sandy chloritic matrix, which has been sufficiently lithified for the formation of thin calcite veins in several places.

Alteration due to ancient weathering is evident as low as 3.5 meters below the upper contact of Unit 5, where it takes the form of iron-staining along foliation planes in gneiss clasts, and along fractures in the matrix. At 3 meters below the top of the unit most of the smaller foliated clasts are easily split, and the larger ones have green rims $1 \mathrm{~cm}$ thick. Alteration increases gradually upward, until in the upper meter only ghosts of the foliated clasts remain.

\section{Unit 6}

The sedimentary breccia rests nonconformably on gray foliated marble and calcsilicate gneiss. The rock is extensively fractured and sheared in the upper part and in places contains narrow zones of cataclasites. The cored sequence, which has a uniform dip of $2^{\circ}$ or $3^{\circ}$, appears to grade downward from foliated marble with a few thin noncarbonate layers to calcsilicate gneiss with light colored marble layers a few millimeters thick.

\section{Interpretation}

The basement rock is similar in lithology to the Koettlitz Marble in the foothills of the Royal Society Range, $450 \mathrm{~km}$ west of Site 270. No similar calcsilicate rocks or marble have been reported from Marie Byrd Land. The Koettlitz Marble was intruded and folded during the late Cambrian to Ordovician Ross Orogeny and may be equivalent to the unmetamorphosed Cambrian limestones in the central Transantarctic Mountains. On this basis, a tentative early Paleozoic age is proposed for Unit 6.
The angularity, size, and lack of sorting of the clasts indicate that the breccia comprising Unit 5 accumulated rapidly under subaerial conditions largely as talus debris. The four thin size-sorted intervals indicate some water transport. The dominance of kaolinite and montmorillonite in the clays of the upper 3 meters supports the view that it is a fossil soil.

The thin sandstones of Units 3 and 4 were deposited in shallow water. Unit 4 may have accumulated in a protected nearshore environment in a lagoonal situation; the abundance of glauconite in Unit 3 indicates slow marine sedimentation on a continental shelf. Thus, Units 5, 4, and 3 appear to record a transition from a terrestrial to a marine shelf environment of deposition.

The silty claystones of Unit 2 have pebbles scattered throughout and record a period of marine glacial sedimentation from about 25 to 16 m.y. ago (Allis et al., this volume). The texture of the sediments can be largely explained as ice-rafted continental till, though there is good evidence to suggest that sediments of the "stratified" facies have been influenced by weak bottom currents (Barrett, this volume). Some thin sandy intervals may have been deposited by turbidity currents, and the occurrence of soft sediment clasts in both "stratified" facies suggests that there has been redeposition by slumping of soft sediments also. The steeply dipping beds within Subunits $\mathrm{F}$ and $\mathrm{H}$ are additional evidence of local sediment instability shortly after deposition.

Subunits $1 \mathrm{~A}$ and $1 \mathrm{~B}$ are grossly similar to Unit 2 in lithology and are believed to represent two different periods of marine glacial sedimentation within the last 5 m.y.

The glacial sediments at Site 270 were probably deposited largely by melting of sediment-bearing bergs calving directly into the Ross embayment. The abundance of diatoms in Subunit $1 \mathrm{~A}$ and in Subunit $2 \mathrm{~A}$ (inferred from the high percentage of cristobalite that it contains today) suggests that the surface waters were ice free for at least part of the year during deposition. The molluscs that occur throughout Unit 2 also indicate relatively ice free conditions, perhaps similar to those around Tierra del Fuego today, at the time of deposition (Dell and Fleming, this volume). The only evidence for a grounded ice shelf at Site 270 is the unconformity between Units 1 and 2, where at least several hundred meters of semilithified and lithified sediment has been eroded.

The substantial change in average sedimentation rate from $41 \mathrm{~m} / \mathrm{m} . \mathrm{y}$. for Unit 2 (Allis et al., this volume) to less than $5 \mathrm{~m} / \mathrm{m} . y$. for Unit 1 may be due to the early Pliocene formation of the ice shelf in the Ross embayment to a form similar to today, with the basal sediment melting out of the ice, long before it reaches the seaward margin of the shelf.

\section{Site $\mathbf{2 7 1}$}

At Site 271, 265 meters of the sedimentary sequence were drilled, but only 15.3 meters of core were recovered before drilling terminated due to the presence of recognizable concentrations of methane, ethane, and ethylene in the recovered sediments. The poor recovery at this site is probably due either to the obstruction of 
the core barrel by ice-transported cobbles and boulders, which are abundant in the sediments in this area, or the presence of sands.

The section sampled shows an apparent lithological uniformity throughout so that all sediments penetrated are assigned to a single lithologic unit. The observed uniformity, however, may be related at least in part to the poor recovery. The sequence consists of clayey sands, silty clays, and silt-clay-sand mixtures, all of which contain granules and larger clasts in varying proportions. In color, the sediments are uniformly dark greenish-gray throughout.

Hardness varies from soft to semilithified. The semilithified interval in Core 5 possibly corresponds to the upper of two strong reflectors observed in the seismic profile. There are, however, soft sediments below this horizon, so that it does not correspond to the beginning of any downhole increase in lithification. Lithologies above and below the horizon are also similar, being silt-clay-sand mixtures, according to grain-size analyses, so that no division of the sequence into formal lithologic units is warranted. There are no indications of bedding throughout the sequence.

Diatoms are the only important biogenous component. Diatom frustules are present in all cores examined, ranging from a trace to $10 \%$ in the upper part of the hole, but showing a sharp increase to about $30 \%$ below Core 19. Microscopic carbonate particles of unknown origin occur sporadically, in trace amounts only, throughout the section. The association of a relatively high abundance of diatom tests with a high gas concentration in Core 24 is notable, but it is not possible to say whether these sediments are in fact the source of the hydrocarbons.

The concentration and maximum diameter of clasts above $5 \mathrm{~mm}$ were measured on cut core faces wherever recovery and lithification permitted. The longest clast measured $91 \mathrm{~mm}$; larger ones may be present as drilled sections. The concentration of larger clasts ranged from less than $1 \%$ to a maximum of $3 \%-5 \%$ of the sediment volume in any core section, but no systematic variations in density were observed throughout the drilled sequence.

Similarly, no variation in the composition of the larger clasts was observed from core to core. Clast lithologies reveal a dominance of igneous and metamorphic rocks, which include several granite types, possible granodiorites, basalts, quartz-biotite gneiss, and quartzites. Subsequent study of clasts collected from Site 271 shows that schist is also common. Sedimentary rocks identified include dark gray argillites, rare yellowish-gray fine sandstone, burrowed silty limestones, and lithified calcareous diamictites. These diamictites may not in fact be clasts at all, but may represent drilled lithified parts of the sequence. As a whole, the clasts vary from angular to subrounded in shape, depending on their composition-quartzites and coarser igneous rocks are generally angular, argillites subrounded. Striations were observed on $7 \%$ of the clasts that were collected.

The poor sorting of the sediments, the size and variety of large clasts, and the presence of diatoms throughout the sequence all suggest that deposition of terrigenous sediment occurred primarily through ice rafting in a marine environment. In contrast to Sites 270 and 273, there is no evidence that sediments in the upper part of the sequence are slightly coarser than those below-processes thus appear to have been operating uniformly throughout the sequence, insofar as can be judged from the poor recovery. No evidence of wave or current activity was seen. Clast composition suggests that source regions lay to the east, rather than in the Transantarctic Mountains to the west.

\section{Site $\mathbf{2 7 2}$}

At Site 272 , thin, soft, diatomaceous sand-silt-clay (Unit 1) overlies a thick sequence of diatomaceous sandy silty claystone (Unit 2, Table 6) in which the hole terminated. A glacial influence throughout the deposition of these beds is indicated by granules and larger clasts dispersed throughout the sequence. Hydrocarbons from Unit 2 are discussed in a separate section.

\section{Unit 1}

Unit 1 is light olive to dark greenish-gray silty clay with 5 to 20 percent sand. The sediment appears to lack stratification, although core deformation would probably have obscured any existing lamination. The upper 1.5 meters (Subunit 1A) has a high proportion of diatoms (40\%), and pebbles and granules are very rare. In contrast, clasts are relatively common (up to $1 \%$ ) in the underlying sediment (Subunit 1B), and the proportion of diatoms is much lower (mostly less than $5 \%$ ). The amount of sand in Subunit 1B was grossly underestimated on the ship; grain-size analyses show that sand constitutes about $40 \%$ of the sediment. Lithologically equivalent subunits occur at Sites 270 and 273 (also termed Subunits 1A and 1B), and at Site 270 their contact was seen to be sharp, but here at Site 272 the contact relationship between the two subunits is not clear. The thin pebbly bed in Subunit 1A could represent an interfingering relationship, but may have been injected during drilling.

Most of the clasts in Subunit 1B are granules, though pebbles more than $10 \mathrm{~mm}$ long average from 5 to 10 per meter of core length. The largest are about $6 \mathrm{~cm}$ long. Smear slides show that the minerals in the sand and silt fraction comprise quartz and subordinate feldspar with trace amounts of biotite, opaques, hornblende, zircon, and pyroxene. Biogenic constituents other than diatoms include trace amounts of sponge spicules and radiolarians. One mollusc shell fragment was found.

\section{Unit 2}

Unit 2 is a diatomaceous sandy silty clay like Unit 1, but is much more lithified. A large pebble obscures the contact between the two units, but the downhole increase in compaction over a few centimeters is marked. Unit 2 is believed to extend down from the top of the dipping strata on the profiler record (Figure 5) at Site 272. The lowest strata of Unit 2 cored are stratigraphically $\sim 100 \pm 40$ meters above the youngest strata of Unit 2 in Hole 270. This interval has not been sampled. 
TABLE 6

Lithologic Units, Site 272

\begin{tabular}{|c|c|c|c|c|}
\hline Unit & Lithology & $\begin{array}{l}\text { Subbottom } \\
\text { Depth } \\
\text { (m) }\end{array}$ & $\begin{array}{l}\text { Unit } \\
\text { Thickness } \\
\text { (m) }\end{array}$ & Age \\
\hline $1 \mathrm{~A}$ & $\begin{array}{l}\text { Diatom silty clay with } \\
\text { rare granules and pebbles }\end{array}$ & $4.0-5.5$ & $\geqslant 1.5$ & Recent \\
\hline 1B & $\begin{array}{l}\text { Diatom-bearing sand-silt- } \\
\text { clay with common granules } \\
\text { and larger clasts }\end{array}$ & $5.5-23.5$ & $\begin{array}{c}18.5 \\
\text { Unconformit }\end{array}$ & $\begin{array}{l}\text { Pliocene (Gauss?) } \\
?\end{array}$ \\
\hline $2 \mathrm{~A}$ & $\begin{array}{l}\text { Sandy silty claystone } \\
\text { with sparse to common } \\
\text { clasts }\end{array}$ & $23.5-145$ & 123 & $\begin{array}{l}\text { Late Miocene to } \\
\text { mid-Miocene }\end{array}$ \\
\hline $2 \mathrm{~B}$ & $\begin{array}{l}\text { Diatom silty claystone } \\
\text { and silty clay diatomite } \\
\text { with rare clasts }\end{array}$ & $145-362$ & 215 & Mid Miocene \\
\hline $2 \mathrm{C}$ & $\begin{array}{l}\text { Silty claystone with rare } \\
\text { clasts }\end{array}$ & $362->434$ & $>72$ & Mid Miocene \\
\hline
\end{tabular}

The strata of Unit 2 in Hole 272 are dominantly olivegray and dark greenish-gray, with the more diatomaceous beds tending to grayish-olive. Granules and larger clasts as much as $10 \mathrm{~cm}$ long form a small $(\leq 2 \%)$, but significant, part of the sediment. The unit is divided into three subunits primarily on the basis of variations in the diatom and sand content.

Subunit 2A, about 120 meters thick, was described initially as silty claystone, though size analyses show it to have a sand content of $24 \%$ to $33 \%$. Diatoms form less than $10 \%$ of the sediment for most of the subunit. The only perceptible bedding is from thin diatom-rich beds which occur at about 15-meter intervals in the upper part of the unit. The beds become more common and thicker below Core 12 as the strata become generally more diatom rich and grade down into Subunit 2B.

Subunit 2B, 215 meters thick, consists mainly of silty claystone (mostly 7\%-9\% sand) with a diatom content ranging from $30 \%$ to $70 \%$. Faint darker plane-parallel and wavy lamination can be found in a few sections, but most of the subunit lacks bedding. Sinuous sedimentfilled tubes 0.5 to $1 \mathrm{~mm}$ across and interpreted as burrows can be seen clearly in Cores 23, 33, and 37 and appear to be widespread, though less distinct, in several other cores. Most burrows are oriented either approximately parallel or perpendicular to the core axis. Highly irregular patches ranging from about a millimeter to several centimeters across have sharp boundaries marked by color differences and are interpreted as deformed soft-sediment clasts. They occur only in Subunit 2B and are best seen in Section 22-5, where the color differences are strongest. Here torn, thin, dark-colored beds appear to have been injected by a lighter colored matrix, giving the appearance of subhorizontal interfingering over a vertical interval of 1 or 2 $\mathrm{cm}$. In Section 27-1, color-laminated parts of the core have been complexly folded and small faults offset some color boundaries. These and a number of other sections have many similar patches with complex sharp sinuous outlines. Some are so subtle as to be evident only on smooth wetted surfaces, but they are similar in form to those with a stronger color contrast and testify to the ex- tensive soft sediment deformation during the deposition of Subunit 2B.

Another interesting structure is developed in Section $25-2$, where a pebble $18 \mathrm{~mm}$ across appears to have penetrated the top of an 11-mm-thick bed. The base of the bed is bowed beneath the pebble and tails of sediment from the bed have partly closed in above it. The structure is believed to have formed by loading soon after the pebble was dropped.

Thin, dark, regularly spaced laminae were observed every 2 to $10 \mathrm{~cm}$ through intervals of stiff to semilithified core as long as 1 meter. Most of the laminae appears to extend without displacement into the softer brecciated core margin. The relationship is not completely clear, and the question of their sedimentary versus drilling deformation origin is unresolved here, though a deformational origin was favored. However, at Site 274 (Section 43-4) similar dark laminae separate and extend down the sides of blocks with fine horizontal lamination, and are clearly a result of drilling deformation.

Between Cores 38 and 39 there is a sudden decrease in diatom content, defining the top of Subunit $2 \mathrm{C}$, a silty claystone. Only two core sections were recovered from the 72-meter-thick unit, but from these and from corecatcher material, the unit can be seen to comprise semilithified silty claystone with traces of diatom debris, and a similar but much harder lithology, partly silicified, in lesser proportions. Both lithologies contain cristobalite, and X-ray analyses of pairs of samples from Core 41 show that it is almost twice as abundant (57\%) in the harder sample. A few beds several centimeters thick of sparse coarse sand and granules occur in both lithologies, and several clasts as much as $7 \mathrm{~cm}$ across were recovered loose in core catchers. The oldest sediments recovered are in the core-catcher of Core 47, which contained mainly cuttings of granule, sand and silt size of the hard silty claystone, with lesser amounts of quartz and feldspar of coarse silt and fine sand grade.

Despite the overall uniform character of the sediments in Subunits 2A and 2B, there is a noticeable variation in the abundance of granules and pebbles from 3 to 4 per meter to as many as 60 per meter over dis- 
tances of tens of centimeters in many places. Also there is a longer-term variation, most clearly seen in the clasts $10 \mathrm{~mm}$ or larger, which are relatively common in Subunit $2 \mathrm{~A}$ ( 1 to 5 per meter), but which are invariably less than 1 per meter in Subunits $2 \mathrm{~B}$ and 2C.

Lithologies of the larger clasts include light and dark colored quartzites, granite, and coarse mafic plutonic rocks. The quartzites in hand specimen closely resemble those of the Crashsite Quartzite in the Ellsworth Mountains $1500 \mathrm{~km}$ to the east. Clasts of quartzose and arkosic sandstones and fine-grained basaltic rocks, which cap the Transantarctic Mountains today, are rare. The smaller clasts include a yellowish-gray clayey limestone and a grayish-olive diatom silty claystone, both of which occur as rounded clasts, indicating that they were at least stiff prior to erosion and redeposition. A collection of 240 pebbles of all sizes from Units 1 and 2 is dominated by metasedimentary rocks (metagraywacke, schist) with some metavolcanic rocks. The remainder comprises equal proportions of sedimentary and plutonic rocks.

The mineralogy of the silt and sand fractions is dominated by quartz and feldspar. Common heavy minerals seen in smear slides are biotite, zircon, epidote, and hornblende. Chlorite, clinopyroxene, garnet, and tourmaline occur sporadically. A few grains of glauconite were found in many samples. X-ray analysis shows that the clay fraction is largely mica with small but persistent amounts of chlorite and montmorillonite.

Biogenic material other than diatoms is chiefly restricted to a few sponge spicules in smear slides. However, Subunit 2B has a number of shell fragments. Most are of thin-shelled bivalves, but several small gastropods were found. In most of the articulated or strongly curved bivalve shells, the matrix is a grayisholive claystone, like the clasts mentioned above, indicating that the shells are transported.

In summary, ice rafting was an important process during the deposition of the sediments of Unit 2 at Site 272 , although for a considerable period sedimentation was dominated by diatom deposition. Variations in clast concentrations suggest that the sedimentary regime was not as stable as, for example, that under which the unstratified facies at Site 270 was deposited. Sediment disturbance by bioturbation and by slumping, indicated by the soft sediment clasts, is extensive in the middle unit. Clast lithologies common in the Transantarctic Mountains are present but rare. Basalt, a widespread rock type in coastal Marie Byrd Land, is also rare. The present geography and the dominance of metasedimentary lithologies suggest a source area in the ice-covered region of southern Marie Byrd Land.

\section{PHYSICAL PROPERTIES AND SUBBOTTOM REFLECTORS}

\section{Site 270}

Wet-bulk density measurements using the GRAPE technique were obtained on one or more sections from nearly all of the cores at this site. These, together with sonic velocity data, are plotted in Figure 10. In these plots the bulk density values through Core 11 have been derived from the analog GRAPE record for unlined segments of the cylindrical semilithified sediment whose diameter was measured directly with a vernier caliper. An approximate correction was applied to remove the effect of varying diameters. For Cores 12 through 48, GRAPE measurements were made on the lined core sections, and no correction for varying diameters has been applied. For semilithified sediment cores, diameter reductions from the $2.60 \mathrm{in}$. usually assumed appear to range from 0.15 to $0.3 \mathrm{~g} / \mathrm{cc}$ less than actual.

The sonic-velocity measurements were made on stiff to lithified cylindrical (or split-cylindrical) core fragments. The only exceptions to this were with Cores 1 and 3 where the measurements were obtained on split and unsplit core sections in the liner.

The plots of bulk density and sound velocity in Figure 10 show no overall trend with depth. The variation in velocity, and to a lesser degree density, seems largely determined by clast abundance. The presence of diagenetic cristobalite in the upper 150 meters of Unit 2 (270-D) seems not to have significantly affected the sonic velocity or density of the rock. The only exception to this is the occasional occurrence of thin carbonate cemented layers of claystone and siltstone which have significantly higher densities and velocities.

In the seismic profiler and sonobuoy records obtained at Site 270, two subbottom reflectors are observable at about 0.14 to $0.16 \mathrm{sec}$ and 0.34 to $0.35 \mathrm{sec}$ (two-way travel time). The first of these should be found between 150 and 190 meters subbottom (Cores 18-21). Although there is a boundary between lithologic units in Core 19, the onboard measurements of velocity and density show no marked changes across this boundary. The deeper reflecting horizon clearly corresponds with the transition from semilithified fine sediment (Units 2-4) to marble breccia and marble (Units 5 and 6) at about 387 meters subbottom (calculated two-way travel time $=$ $0.34 \mathrm{sec})$.

\section{Site 271}

Wet-bulk density measurements using the standard GRAPE technique were obtained on Cores 1, 3, 5, and 24 from this site. All measurements were on core sections in lines. Seismic-velocity measurements were obtained on Cores 1 through 5, 19, and 20. The measurements for Cores 1 through 4 were made on split and unsplit cores in the liner while those for 5,19 , and 20 were made on sediment chunks. The data are plotted in Figure 11. The apparent decrease in density from Core 3 to Core 5 is significantly more dense than the soft to stiff material above it.

The profiler and sonobuoy records at Site 271 show a series of clear reflectors at 0.06 to $0.07 \mathrm{sec}, 0.13$ to 0.15 $\mathrm{sec}$, and 0.28 to $0.30 \mathrm{sec}$ of two-way travel time. Several deeper reflectors are suggested at 0.35 to $0.40 \mathrm{sec}, 0.5$ $\mathrm{sec}, 0.6 \mathrm{sec}$, and 0.75 to $0.80 \mathrm{sec}$. With the exception of the topmost of these, they all mark surfaces dipping at about $1^{\circ}$ to the northeast with the dip generally being greater the deeper the reflector and with the dip on a given reflector generally increasing up-dip. The reflector at 0.06 to $0.07 \mathrm{sec}$ is peculiar in that it almost parallels the general form of the bottom topography, lies between 
50 and 80 meters, and appears to either truncate or pass through the dipping reflectors as they approach the surface.

Of these reflecting horizons only the shallowest two would have been penetrated at Site 271. On the basis of the observed lithologic changes and the two-way travel time computed from the sonic-velocity data, it seems certain that the 0.06 to $0.07 \mathrm{sec}$ reflecting horizon is represented by the top and/or bottom of Core 5 at 70-80 meters subbottom. The reflector at 0.13 to $0.15 \mathrm{sec}$ may well be associated with a pebble-, cobble-, and/or boulder-rich deposit as suggested by the samples found in Cores 12 through 16.

\section{Site 272}

Sonic-velocity and GRAPE wet-bulk density measurements were made on nearly all cores from this site (Figure 12). No corrections for varying diameters have been applied to the bulk-density data so the values plotted should be considered minimal. The apparent decrease in density between Cores 2 and 3 probably represents a decreased diameter effect in going from soft sediments in Core 2 which fill the liner to the semilithified sediments in Core 3 which do not. All sonic-velocity measurements, with the exception of those on Cores 1 and 2, were made on chunks of stiff, semilithified, and lithified sediment. Velocities in Cores 1 and 2 were measured on the unsplit sections. The plotted values of sonic velocity are with few exceptions those perpendicular to the bedding.

The downhole variations in density and velocity clearly reflect the major lithologic changes which are found. Most striking is the change from the diatom-bearing silty claystone above 150 meters subbottom to the diatom silty claystone and silty clay diatomite below. At this boundary GRAPE density decreases from nearly $2.00 \mathrm{~g} / \mathrm{cc}$ (nominal) to less than $1.70 \mathrm{~g} / \mathrm{cc}$ (nominal), while velocity similarly shows a marked decrease from $2.10 \mathrm{~km} / \mathrm{sec}$ to about $1.80 \mathrm{~km} / \mathrm{sec}$. Both density and velocity remain almost constant in the interval from 200 to 350 meters subbottom, and what little variation is present appears to be reflected in both parameters.

Several reflecting horizons are observed in the profiler records obtained on approach to and departure from Site 272. Two-way travel times for these reflectors are 0.05 to $0.07 \mathrm{sec}, 0.15$ to $0.17 \mathrm{sec}, 0.25$ to $0.28 \mathrm{sec}$, and 0.35 to $0.37 \mathrm{sec}$. The shallowest of these appears to correspond to the velocity and density increase observed between Cores 6 and 9. It is worth noting that in this same interval there is an apparent maximum in the gas content of the cored sediment. Its effect on the in situ physical properties of the sediment is not known.

The reflecting horizon at 0.15 to $0.17 \mathrm{sec}$ clearly corresponds to the lithologic boundary between Units $2 \mathrm{~A}$ and $2 \mathrm{~B}$ and lies at about 160 meters subbottom. The gas content of the sediment in Unit $2 \mathrm{~B}$, diatom silty claystone and silty clay diatomite, appears to reach a maximum near the top of the unit and declines slowly with increasing depth until near the bottom of the unit it again rises to a sharp apparent maximum.

The boundary at about 360 meters subbottom between lithologic Subunits 2B and 2C corresponds quite closely with the deepest reflecting horizon observed on the seismic profiler records, at 0.35 to $0.37 \mathrm{sec}$ of two-way travel time.

The weakest reflector is that at 0.25 to $0.28 \mathrm{sec}$. There is no obvious lithologic change in Cores 25 through 29 which span the depth interval within which this reflecting horizon should be found. The $30 \mathrm{~cm}$ of carbonate-cemented material recovered in Core 27, Section I would provide an adequate change in acoustic impedance, but it would have to be almost a factor of $10 \times$ thicker in order to be "seen" by the profiler.

\section{GEOCHEMISTRY OF INTERSTITIAL WATER}

\section{Site $\mathbf{2 7 0}$}

Alkalinity, $p \mathrm{H}$, and salinity were measured in the usual manner from 11 samples, the deepest being at 378 meters (Table 7). There are two prominent features in the curves plotted in Figure 6. In one sample at 120 meters, $p \mathrm{H}$ is unusually low and salinity unusually high. The lithology of the immediately underlying sediment provides no clue as to the reason for this anomaly; but since the sample was taken at the top of Section 1, some downhole contamination could have taken place.

Below about 320 meters, there is a marked increase in alkalinity (from a range of 1 to $3 \mathrm{meq} / \mathrm{kg}$ above to a maximum of $25 \mathrm{meq} / \mathrm{kg}$ below), and a slight increase in salinity and decrease in $p \mathrm{H}$. There is no corresponding pronounced change in lithology. There is no clear explanation of the abrupt change in geochemical characteristics of the waters below 320 meters. They may be related to upward diffusion of waters from the basement unconformity at 387 meters, or to diagenesis of the lower part of the Tertiary sequence. It is interesting to note that detrital hornblende and epidote are not found below about 320 meters, perhaps because of interstratal solution.

\section{Site 271}

Only one interstitial water sample was taken, at a depth of 52 meters (Table 8). This had a high alkalinity $(10 \mathrm{meq} / \mathrm{kg})$, consistent with the high gas concentrations and high organic carbon content of the sediments in this hole. The relationship between alkalinity and high organic matter is discussed in the report for Site 262 (Leg 27).

The occurrence of gas is discussed in a separate section.

\section{Site $\mathbf{2 7 2}$}

Routine analyses of interstitial water are shown in Figure 7. As at Site 271, alkalinity is quite high (mostly around $6 \mathrm{meq} / \mathrm{kg}$ ), consistent with the presence of methane and carbon dioxide gas. Alkalinity is much higher than at Site 270, where no gas was detected. Salinity gradually decreases downhole to around $29 \%$ at 350 meters. This is slightly higher than the salinity in the deeper parts of Hole 270. $p \mathrm{H}$ ranges from 7.12 to 8.15. A similar range is found at Hole 270 .

The occurrence of gas is discussed in a separate report in the description of Site 271. 
TABLE 7

Summary of Shipboard Geochemical Data, Site 270

\begin{tabular}{|c|c|c|c|c|c|c|}
\hline $\begin{array}{c}\text { Sample } \\
\text { (Interval } \\
\text { in } \mathrm{cm} \text { ) }\end{array}$ & $\begin{array}{l}\text { Depth Below } \\
\text { Sea Floor } \\
\text { (m) }\end{array}$ & $\begin{array}{l}\text { Punch- } \\
\text { in }\end{array}$ & $\begin{array}{l}\text { Flow- } \\
\text { through }\end{array}$ & $\begin{array}{l}\text { Alkalinity } \\
(\mathrm{meg} / \mathrm{kg})\end{array}$ & $\begin{array}{c}\text { Salinity } \\
(\% \circ)\end{array}$ & Remarks \\
\hline Surface Seawater & & 8.10 & 8.07 & 2.64 & 34.6 & \\
\hline $1-2,0-10$ & $1.50-1.60$ & 7.24 & 7.30 & 3.03 & 34.6 & \\
\hline $6-1,144-150$ & $35.94-36.00$ & 7.24 & 7.60 & - & 34.4 & \\
\hline $8-2,144-150$ & $56.44-56.50$ & 7.24 & 7.97 & 3.32 & 32.2 & \\
\hline $12-1,0-6$ & $91.50-91.56$ & 7.24 & 7.78 & 2.35 & 29.7 & \\
\hline $15-1,0-6$ & $120.00-120.06$ & 7.24 & 6.50 & 1.66 & 33.0 & Lithified salty clay? shell frags \\
\hline $18-4,144-150$ & $154.44-154.50$ & 7.24 & 7.41 & 1.46 & 28.6 & \\
\hline $23-6,0-6$ & $203.52-205.56$ & - & - & - & - & $\begin{array}{l}\text { Could not squeeze any water } \\
\text { from sample }\end{array}$ \\
\hline $28-5,144-150$ & $250.94-251.00$ & 7.24 & 8.29 & 0.98 & 28.0 & \\
\hline $31-6,144-150$ & $280.94-281.00$ & 7.24 & 8.43 & 1.17 & 27.8 & \\
\hline $35-4,144-150$ & $315.94-316.00$ & 7.24 & 8.66 & 0.98 & 27.4 & Lithified clayey siltstone \\
\hline $39-4,0-10$ & $352.50-352.60$ & 7.24 & 7.99 & 9.58 & 27.8 & Lithified sandy clayey siltstone \\
\hline $43-2,0-6$ & $378.00-378.06$ & 7.24 & 7.33 & 24.73 & 28.9 & Lithified clayey siltstone \\
\hline
\end{tabular}
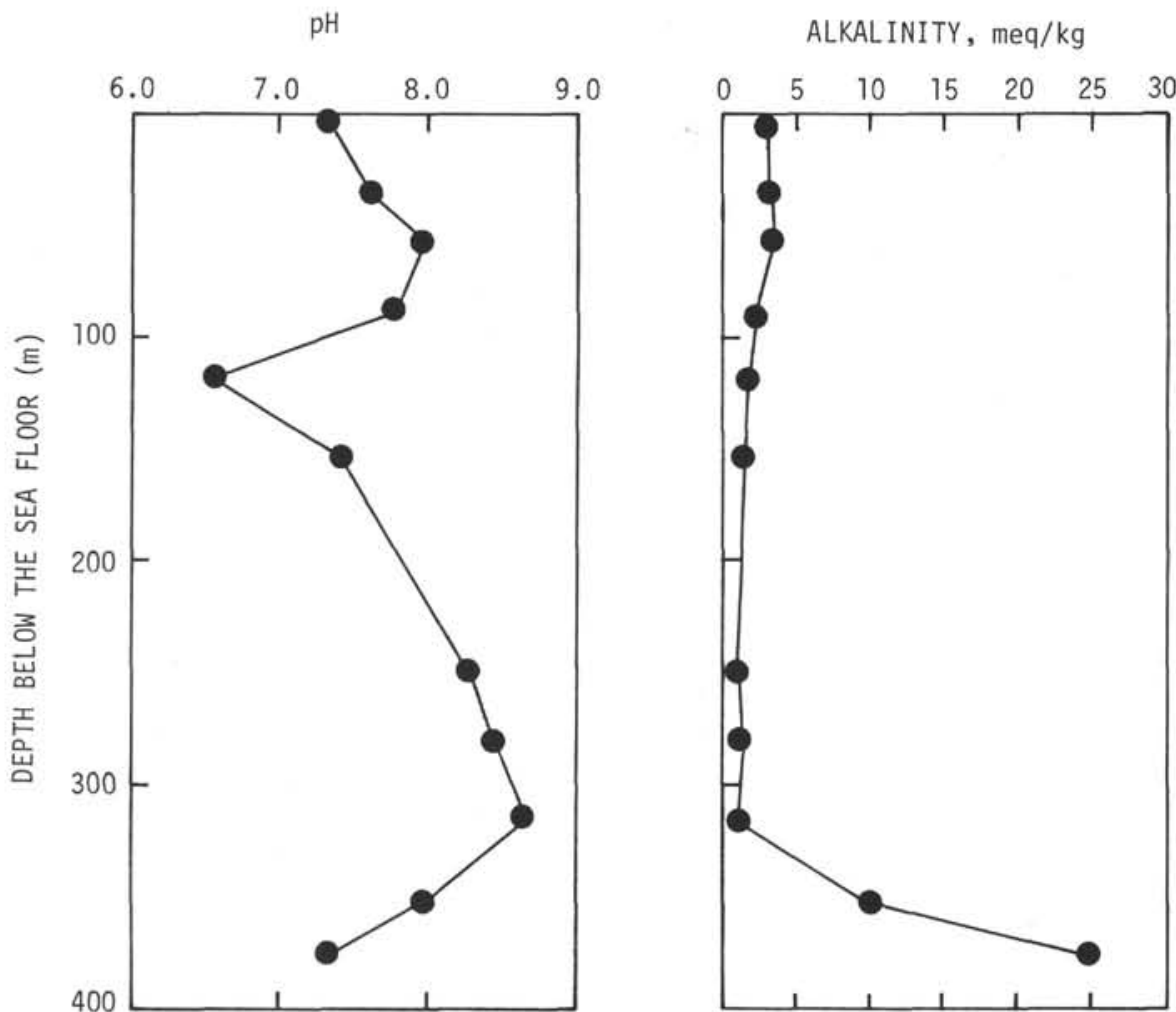

SALINITY, \%०

Figure 6. Shipboard measurements of $\mathrm{pH}$, alkalinity, and salinity in sediment pore waters at Site 270.

TABLE 8

Summary of Shipboard Geochemical Data, Site 271

\begin{tabular}{|c|c|c|c|c|c|c|}
\hline \multirow{2}{*}{$\begin{array}{c}\text { Sample } \\
\text { (Interval } \\
\text { in } \mathrm{cm} \text { ) }\end{array}$} & \multirow{2}{*}{$\begin{array}{l}\text { Depth Below } \\
\text { Sea Floor } \\
\text { (m) }\end{array}$} & \multicolumn{2}{|c|}{$p \mathrm{H}$} & \multirow[b]{2}{*}{$\begin{array}{l}\text { Alkalinity } \\
\text { (meg/kg) }\end{array}$} & \multirow[b]{2}{*}{$\begin{array}{c}\text { Salinity } \\
(\%)\end{array}$} & \multirow[b]{2}{*}{ Remarks } \\
\hline & & $\begin{array}{l}\text { Punch- } \\
\text { in }\end{array}$ & $\begin{array}{l}\text { Flow- } \\
\text { through }\end{array}$ & & & \\
\hline Surface Seawater & & - & 7.82 & 2.44 & 35.8 & \\
\hline $3-2,144-150$ & $52.44-52.50$ & - & 7.36 & 10.17 & 33.8 & $\begin{array}{l}\text { Hole abandoned due to large } \\
\text { concentration of gas in the } \\
\text { sediments }\end{array}$ \\
\hline
\end{tabular}



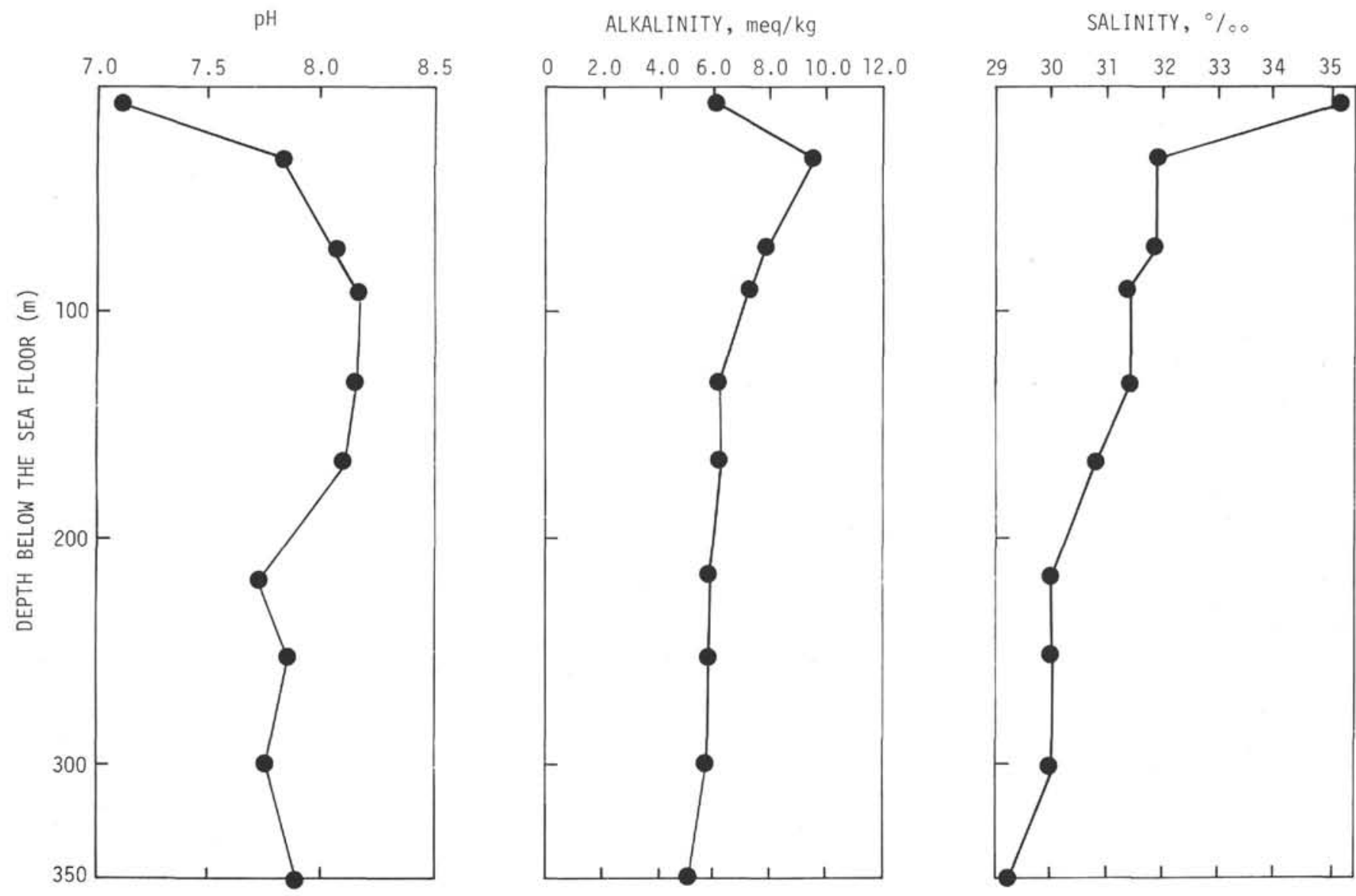

Figure 7. Shipboard measurements of $\mathrm{pH}$, alkalinity, and salinity in sediment pore waters at Site 272.

\section{BIOSTRATIGRAPHIC SUMMARY, SITE 270}

Foraminifera are well represented throughout the Oligocene-early Miocene succession at Site 270. Radiolaria, diatoms, and nannoplankton occur sporadically through the succession but always in small numbers. Benthonic foraminifera provide the best evidence for the age of these sediments and also provide some indication of the climatic and sedimentary history in this part of the Ross Basin.

From a consideration of the foraminifera present, their diversity and their abundance, it has been deduced that this part of the Ross Basin deepened gradually from a complex of near-shore facies in the Oligocene to a depth of about 500 meters in the early Miocene. Oligocene benthonic foraminifera exhibit some affinity to New Zealand faunas and can be classed as cosmopolitan. A cool temperate marine climate is indicated. Later in the Oligocene and during the early Miocene, foraminiferal faunas developed a strongly polar aspect with strong affinities to Neogene microfaunas of Alaska and other northern high latitude areas. This polar endemism makes correlation with mid and low latitude biozonations extremely difficult. The development of these endemic faunas coincides with the deposition of the first ice-rafted sediments, and the faunas reflect progressive cooling during the latest Oligocene and early Miocene. Benthonic foraminifera were not greatly affected during the deposition of the first two ice-rafted pebble beds (lithological units, diamictite $2 \mathrm{G}$ and $2 \mathrm{I}$ ) in the uppermost part of the Oligocene succession, suggesting that ice cover was not permanent and that the onshore ice cover was probably not fully developed. Benthonic foraminifera are poorly developed or entirely absent in the thick diamictite (Subunit 2A) at the top of the early Miocene succession, suggesting much more extreme glacial conditions onshore and the likelihood that permanent sea or shelf ice was in existence. Progressive cooling is also reflected in the record of the planktonic foraminifera. Although this group was only poorly developed in the Oligocene, by the early Miocene it was, with a single exception, not represented in the area at all.

The two diamictite units (2G and $2 \mathrm{I})$ contain a considerable variety of recycled biogenic debris derived from terrestrial and shallow-water marine sources. Little biogenic debris was found in the upper diamictite (Subunit 2A) other than poorly preserved benthonic foraminifera, and it is thought that this unit had as its source recycled marine sediments, perhaps picked up from the sea floor by a grounded ice shelf. The presence of quite good calcareous benthonic faunas throughout most of the Oligocene and early Miocene indicates that the lysocline lay at depths greater than 500 meters and probably much deeper. 
Radiolaria and diatoms are poorly represented and when present are mostly fragmented. Their poor record could be taken to indicate the presence of waters inhospitable to plankton, perhaps the result of high terrigenous runoff and/or existence of adverse hydrological conditions.

Although the sediments recovered from Site 270 are the oldest Ross Sea sediments known to be in situ, it should be noted that reworked older marine sediments have been reported within elevated Quaternary sediments of the McMurdo Sound area. Paleontological material includes late Cretaceous foraminifera in eastern Taylor Valley (Webb, 1973), Eocene gastropods at Cape Crozier, Ross Island (Hertlein, 1969), and Eocene microfloras at Minna Bluff and Black Island (Cranwell et al., 1960; Speden, 1962; McIntyre and Wilson, 1966; Wilson, 1967; and Harrington, 1969). Fossils in these siltstones (or hard graywackes) indicate deeper preOligocene marine conditions than that apparent from investigation of basal Oligocene sediments at Site 270 . Since Site 270 is located over a basement "high," it is probable that deeper water Oligocene facies are also present in other parts of the Ross Basin.

\section{Foraminifera}

\section{Pliocene-Quaternary}

The top of Core 1 contains rare specimens of Miliammina arenacea, which, according to Fillon's (1972) thesis, is characteristic of Brunhes series sediments. Globocassidulina biora in the core catcher of Core 3 indicates sediments of the Gauss series.

\section{Oligocene-Early Miocene}

Abundance and preservation: Forty-six samples from the 350-meter-thick succession of mid Cenozoic sediments at this site were examined. Abundance and state of preservation are widely variable. The highest faunal return was about 100 tests from a 500-g sample. It is clear then that abundances are generally low compared with lower latitude areas. Agglutinated tests are particularly common low in the succession with tests being large, often deformed, and composed of coarse quartz and to a lesser extent glauconite. The larger calcareous tests tend to be filled with fine matrix, pyrite, or ingrowths of calcite. These are often broken or decorticated to varying degrees. Some internal casts were also observed. By contrast, the smaller calcareous benthonics are well preserved and contain little or no material within chambers. The wide variety of preservation in certain parts of this succession might result from selective weathering of certain taxa, but in view of the prevalence of ice rafting in these sediments, this feature might also result from the recycling of older faunas.

Taxa present: The following taxa were recorded in the 46 samples examined. A single asterisk denotes that this taxon is commonly present, a double asterisk denotes that it is a particularly dominant taxon:

Rhizamminidae, Saccammina sp., Reophax sp., Ammodiscus spp., Cyclammina sp. (**), Ammobaculites sp., Ammomarginulina sp., Gaudryina $\mathrm{cf}$. reussi Stache, Textularia sp., Ataxophragmiidae, Lenticulina (Lenticulina) sp., Lenticulina (Astacolus) sp., Lenticulina (Marginulina) sp., Dentalina sp., Nodosaria sp., Lagena globulosa, Lagena sulcata, Lagena apiculata, Fissurina 5 spp., Polymorphiniidae(*), Ramulina sp., Cyclogyra sp., Quinqueloculina sp., Globobulimina sp. (*), Fursenkoina sp., Uvigerina sp. $\left({ }^{* *}\right)$, Angulogerina sp. $\left({ }^{* *}\right)$, Nonionella sp., Pullenia bulloides, Pullenia quinqueloba, Melonis sp., Elphidium (=Cribroelphidium) sp. (*), Sphaeroidina bulloides, Buccella sp., Eponides sp., Epistominella exigua, Alabamina sp., Globocassidulina sp. (**), Cassidulinoides sp. (**), Ceratobuliminidae indet., Cibicides sp. (**), Anomalinoides spp., Gyroidinoides zelandica-allani (Finlay) group (*), Chiloguembelina $\mathrm{cf}$. cubensis, Globigerina sp., Globorotalia sp., and Globigerinoides trilobus.

Age determination: The faunas in the lower part of the succession are cosmopolitan in their affinities and an approximate correlation with the New Zealand midTertiary succession is possible. However, the middle and upper parts of the succession develop a strong polar endemism, and correlation beyond the Ross Sea area is not possible at this time. This pattern probably reflects the temperature trends for the mid Tertiary in this region. This aspect will be discussed below.

The occurrence of two well-preserved specimens of Chiloguembelina cubensis in Sample 34, CC indicates that this level and below is mid Eocene to mid Oligocene. The occurrence of this species at Sites 267 and 270 suggests a tolerance of cool temperate waters. It should therefore be noted as a potentially useful index species for use in high latitude biostratigraphy.

Minute tests of Globigerina sp. are present in Samples $36-6,115-123 \mathrm{~cm}$ and $39-6,24-26 \mathrm{~cm}$. A single specimen of Globorotalia sp. also occurs in the latter sample. At the present time, it seems that these are of no use in dating these sediments.

A large Gyroidinoides occurs in 40-5 (top of section) and $44, C C$ and is likened to the New Zealand G. zelandica (Finlay) and G. allani (Finlay). The former ranges from early Oligocene to Recent and the latter from early to late Oligocene. This confirms that the basal sediments are no older than Oligocene. A large Globobulimina is present in 44, CC and ranges as high as 17, CC (some of these higher occurrences might in fact be reworked). In New Zealand this genus is not known before the early Oligocene.

A single specimen of Globigerinoides trilobus was found in 28, CC. Since G. trilobus has not been reported from sediments younger than middle Miocene in piston cores farther north in the Antarctic region, it is likely that sediments of $28, \mathrm{CC}$ are of early Miocene or younger age. It should be noted, however, that Globigerinoides is not a high latitude genus, and the occurrence of this specimen in a sample from the Ross Sea may well be due to laboratory contamination. Elphidium (=Cribroelphidium) sp. first appears in 33-3 and is common throughout the middle part of the succession. This genus first appears in the Miocene. Consequently, it is suggested that the OligoceneMiocene boundary be placed between 34, CC and 33-3.

A single well-preserved specimen of Gaudryina reussi Stache occurs in 19-5, 113-124 cm. In New Zealand this 
species ranges from early Eocene to early Miocene. Arenonodosaria robusta (Stache) is present in 26-6 and has a New Zealand range of early Eocene to early Miocene. On the basis of the foregoing evidence, it is suggested that the interval $19-5$ down to $28, C C$ is early Miocene. The interval $5, \mathrm{CC}$ to $18, \mathrm{CC}$ contains a low diversity and poorly preserved fauna for which a tentative Miocene age is suggested. It should be mentioned that some of the species and most of the genera are known to range down into the Eocene in higher latitude areas. However, the more diagnostic taxa suggest that the base of the succession is no older than Oligocene.

\section{Nannofossils}

Coccoliths were noted in 30 sedimentological smear slides from Cores $4,15,17,18,20$ to $28,32,34,36,37$, and 38 , but they are generally present in trace amounts only. Species present included a small Reticulofenestra sp., Cyclicargolithus floridanus, and Coccolithus pelagicus.

\section{Radiolaria}

Radiolaria are generally absent or exist only as unidentifiable fragments in most of the samples studied, except the following:

Core 1: a few well-preserved Radiolaria (Antarctissa strelkovi, A. denticulata, and Triceraspyris antarctica); post-Miocene.

Sample 3-1, 105-107 cm: fragments of Spumellaria.

Sample 15, CC: fragments of Spumellaria.

\section{Diatoms}

Site 270 is barren of diatom remains with the exception of Core 1. From the surface (1-1, 0) through 1-2, 40 $\mathrm{cm}$ is an assemblage of diatoms suggestive of the Coscinodiscus lentigenosus Zone. After this level no diatom remains could be found.

\section{Palynology}

Twenty-two samples were examined for pollen. Units 3 and 4 were examined in an attempt to establish their age. Both these units and the overlying glacial marine Unit 2 would, it was hoped, also yield palynological evidence bearing on the nature of terrestrial vegetation during the early phases of glaciation.

\section{Unit 2}

The ratio of terrestrially derived spores and pollen to marine forms (dinoflagellates and acritarchs) is greatest in Subunit 2J, with a value of $1: 2$ or more. This ratio declines upward through Unit 2, although ratios of $1: 3$ occur in Core 25 (Subunit 2F) and Core 15 (Subunit 2B). Swarms of acritarchs (outnumbering pollen by $25: 1$ ) occur in Subunits 2G and 2C-only the finest terrestrial debris is present at these horizons. This palynofacies is shown in Figure 8.

In Subunit 2J, Sections 5 and 6 of Core 43 represent a distinctive palynofacies (Figure 9), which contains abundant plant tissue, much degraded, possibly by the activity of burrowing organisms. Foram test linings and mineralized diatom fragments are also present, as are rare pollen grains. The general appearance is that of a near-shore, shallow depositional environment. Dinoflagellates of this interval include Selenopemphix nephroides, Lejeunia sp., and cf. Muderongia sp. S. nephroides has hitherto only been recorded from mid to late Oligocene sediments in Germany (Benedek, 1972).

Cores 41 and 42 yielded abundant well-preserved pollen, plus rare acritarchs. The pollen assemblage is dominated by Nothofagidites spp., with grains of the fusca type slightly more abundant than those of the brassi group. Proteaceous pollen is next in abundance, with $P$. minimus and $P$. subscabratus most common. Small myrtaceous pollen grains also occur, as do rare tricolpate forms. Conifer pollen is chiefly podocarpaceous, including Podocarpidites sp., Microcachryidites antarcticus, Phyllocladites mawsoni, and Podosporites microsaccatus.

These assemblages are similar in composition to those described from Eocene erratics at McMurdo Sound by McIntyre and Wilson (1966), who suggested that they reflected a vegetation growing under cool temperate conditions. The McMurdo erratics, however, contain a dominance of dinoflagellates; none occur in the lowest sediments of Unit 2. This suggests that the basal Unit 2 sediments do not contain pollen reworked from this Eocene source; the lack of other obviously recycled pollen (e.g., Paleozoic or Mesozoic forms) is a further point suggesting that the assemblages from this interval may be primary, and represent vegetation which existed contemporaneously with early ice advances. These assemblages of late Oligocene age may represent the youngest vegetation recorded from the main Antarctic continent. Assemblages from Subunits $2 \mathrm{~F}$ and $2 \mathrm{~B}$ do contain Eocene-Oligocene dinoflagellates, so pollen in these may well be recycled.

\section{Unit 3}

Palynomorphs are sparse in this greensand unit. No pollen was observed although degraded plant tissue is common. Rare dinoflagellates include Deflandrea macmurdoensis, D. asymmetrica, Areosphaeridium diktyoplokus, Selenopemphix nephroides, and Wetzeliella cf. articulata. The overlap of known ranges of these forms suggests an Oligocene age for the unit. Most forms have hitherto been recorded from probable late Eocene strata; $S$. nepheoroides, however, has only been recorded previously in the mid to late Oligocene. There appears to be only a short time interval represented by the break between Units 2 and 3.

\section{Unit 4}

This unit yielded only coarse woody fragments; the silt-sized fraction (which contains most palynological material) has probably been removed by winnowing.

\section{BIOSTRATIGRAPHIC SUMMARY, SITE 271}

Site 271 is characterized by the general absence of microfossils, and most cores were barren. It was possible, however, to ascertain reasonably good ages on the basis of diatoms and radiolarians for both the top and bottom of this section. Foraminifera were not reported for any portion of the section at this site. 


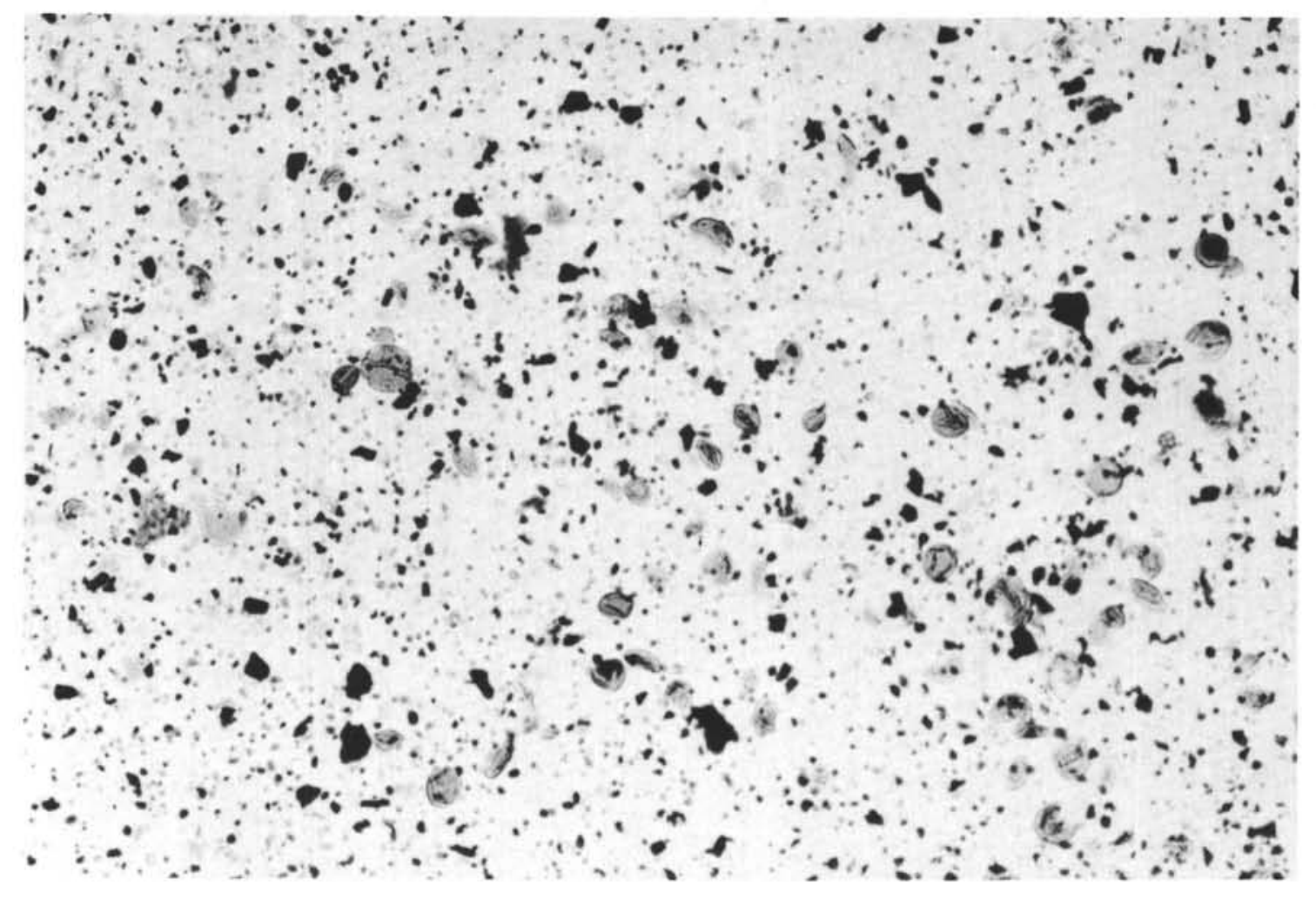

Figure 8. Acritarch palynofacies, Site 270.

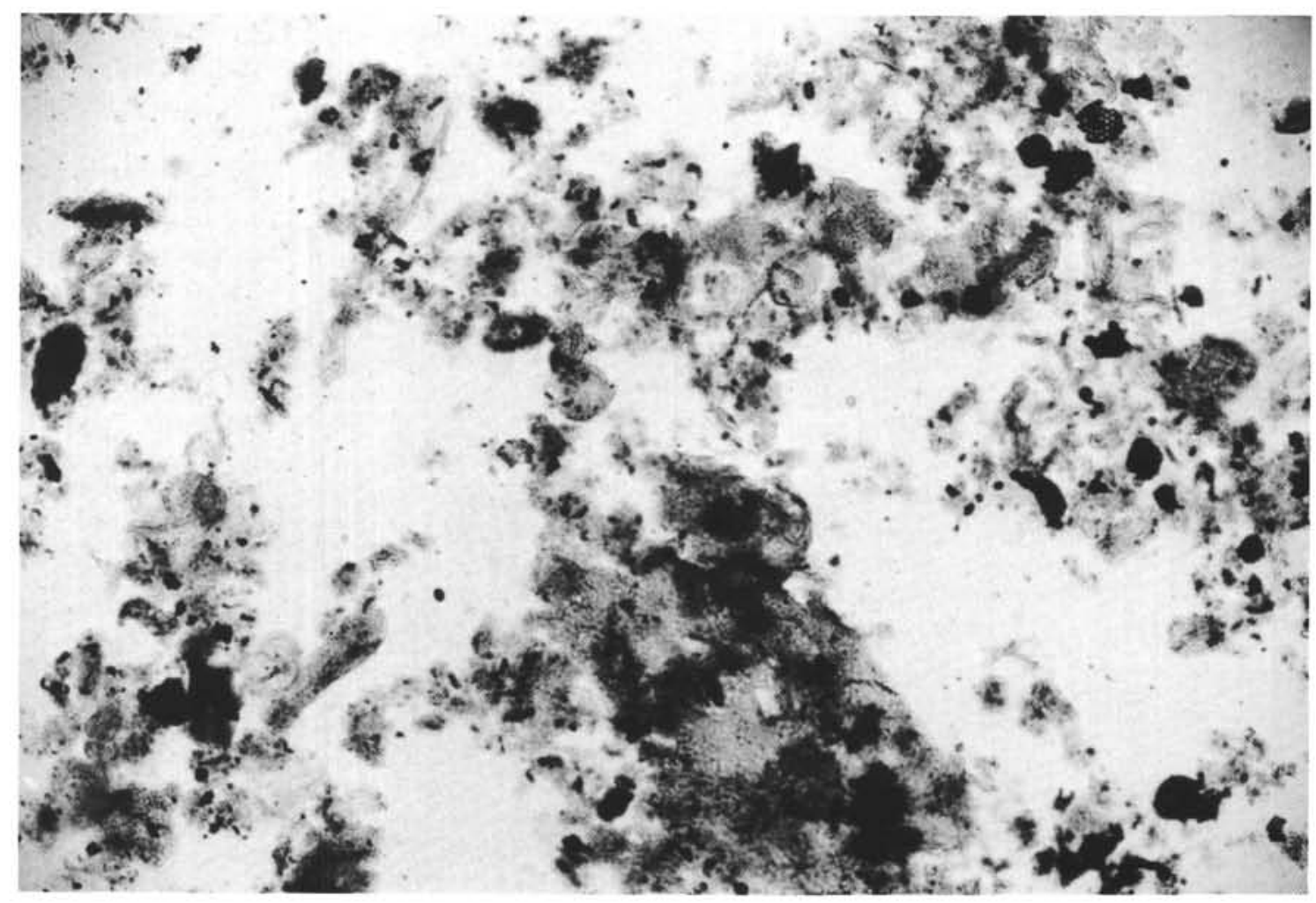

Figure 9. Palynofacies with abundant, much degraded plant tissue; Site 270, Core 43. 
In Core $1(15 \mathrm{~cm})$ Radiolaria of the genus Antarctissa indicate a paleomagnetic age of Brunhes (0-0.7 m.y.). Only unidentifiable diatom fragments were recorded from Cores 1-15. In Sample 16, CC Cosmiodiscus intersectus $(\mathrm{F})$ and Actinocyclus ehrenbergii $(\mathrm{C})$ are recorded, indicating an age of (lower?) Pliocene. Samples 19, $\mathrm{CC}$ to $23, \mathrm{CC}$ contained the same assemblage, but in much greater abundance, making a lower Pliocene age very reasonable. In $24, \mathrm{CC}$ the Radiolaria (Triceraspyris $\mathrm{sp}$.$) and diatoms (C. intersectus [\mathrm{A}]$, A. ehrenbergii $[\mathrm{A}]$, Actinocyclus ingens $[\mathrm{VR}])$ occur together, indicating an age of lower Pliocene (Tau Zone [rads]; lower Gilbert [diatoms]).

\section{Foraminifera}

No foraminifera were found at this site.

\section{Nannofossils}

No nannofossils were found in this site.

\section{Radiolaria}

Radiolaria are generally absent in most of the samples studied except the following:

Sample 1-1, 15-17 cm: a few moderately preserved Radiolaria (Antarctissa denticulata, A. strelkovi, Triceraspyris antarctica, and Spongotrochus glacialis); postMiocene.

Sample 2-1, 132-136 cm: traces of moderately preserved Radiolaria (Antarctissa denticulata, A. ewingi, Spongotrochus glacialis, and Antarctissa strelkovi); Pliocene.

Sample 9-1, 74-78 cm: a few moderately preserved Radiolaria (Antarctissa denticulata, A. ewingi, Desmospyris spongiosa, and Helotholus vema); $H$. vema Zone.

Sample 24, CC: rare and poorly preserved Radiolaria (Spongotrochus glacialis and Dendrospyris haysi); Miocene?.

\section{Diatoms}

Samples taken from this site contain unidentifiable fragments or are barren except for the following instances. Sample 16, CC contains Cosmiodiscus intersectus, Actinocyclus ehrenbergii?, and Thalassiosira gracilis, which suggests an early Pliocene age. Sample 19, CC contains C. intersectus, $A$. ehrenbergii, and Stephanopyxis turris (early Pliocene?). Sample 24, CC contains the same assemblage with rare occurrences of Actinocyclus ingens, indicating this sediment may be of early Pliocene/late Miocene age. The early Pliocene age is more probable because of the lack of any other late Miocene diatoms.

\section{Silicoflagellates}

Three characteristics-low diversity, abundance, and skeletal variability - are indicative of the silicoflagellate assemblages at this and other Ross Sea sites. The high degree of silicoflagellate skeletal variability at this site makes taxonomic placement difficult, therefore, the species described are considered as sensu stricto.

Rare specimens of Distephanus speculum with wide apical rings were found in Sample 1-1, 10-12 cm. This particular morphotype of Distephanus speculum is often found in Matuyama sediments; however, no age designation is made due to the lack of other diagnostic Matuyama silicoflagellates. Sample 1, CC contained a couple of specimens of Naviculopsis biapiculata which may have been winnowed from an Eocene or Oligocene source elsewhere in the Ross Sea.

The remainder of the site samples examined were barren with the exception of Cores 16, 19, and 24 . Samples 16, CC and 19, CC only yielded several morphotypes of Distephanus speculum of an undeterminable age. Silicoflagellates were surprisingly common and diverse in Sample 24, CC. This basal core contains Dictyocha pseudofibula, Cannopilus binoculus, Distephanus boliviensis, D. speculum s.l., and D. quinquangellus. This assemblage is somewhat similar to that of the Distephanus boliviensis Zone or upper Dictyocha pseudofibula Zone, thereby indicating an age of approximately 3.0 to $3.7 \mathrm{~m}$.y.

\section{BIOSTRATIGRAPHIC SUMMARY, SITE 272}

Diatoms are distributed throughout the entire 425 meters of this mid-Cenozoic succession of silty clay and silty claystone. Middle and late Miocene and early Pliocene ages have been determined by means of this group. Foraminifera are found only in the lowermost 150 meters of the succession and indicate middle Miocene ages. Ages based on foraminifera and diatoms are in general agreement. Radiolaria occur only rarely (in 15, CC; 44, CC; and 45, CC) and are of no use in dating. There appears to be an inverse relationship between abundance/diversity of foraminifera and diatoms, the former being abundant and diverse low in the succession but terminating abruptly, whereas diatoms range through the entire succession, becoming particularly abundant above the level of foraminiferal extinction. Some of the higher diatom occurrences constitute up to $70 \%$ of the sediment as judged from smear slide counts. While it is possible that the extinction of calcareous benthonics might be explained as a postdiagenetic feature, it seems more likely that local or regional fluctuations of the lysocline are involved. Analysis of the benthonic foraminifera indicates bottom depths in the region of 500 to 1000 meters, making the latter explanation quite feasible. It is tentatively suggested that interaction of a thick and broad ice shelf front with marine waters may have brought about major hydrological fluctuations. These induced massive diatom blooms, raised the CCD, and inhibited the development of pelagic and benthonic carbonate taxa.

\section{Foraminifera}

A total of 20 samples was examined in detail. Faunas are poor, particularly in the upper part of the succession. Sample 1-3, 110-114 cm contains a single broken Globocassidulina sp.; 8, CC a Cibicides sp.; and in 9, CC a miliolid. All occurrences are considered to result from reworking. Samples $6, \mathrm{CC}$ and $22, \mathrm{CC}$ contain a few shell fragments. Samples 2-4, 90-94 cm; 3-3, 60-67 cm; 5, $\mathrm{CC} ; 7, \mathrm{CC} ; 10, \mathrm{CC}$; and 19, CC contain neither foraminifera nor other biological material. 
In the lower half of the succession several good foraminiferal faunas were extracted. These are present in 30-1, 143-150 cm; 34, CC; 40, CC; and 44, CC. A high diversity of 14 species was recorded in 40, CC. Samples $37-3,60-67 \mathrm{~cm}$; 39-1, 130-134 cm; 39, CC; and 42-1, $92-$ $98 \mathrm{~cm}$ each contain meager faunas of a few specimens, probably all reworked. Sample $37-3,60-67 \mathrm{~cm}$ contains ostracodes, and 42-1, 92-98 cm diatoms, sponge spicules, and shell fragments.

The following taxa are present in $30-1,143-150 \mathrm{~cm}$; 34, CC; 40, CC; and 44, CC: Cyclammina sp., Lenticulina (Lenticulina) sp., Lagena spp., Fissurina spp., Quinqueloculina sp., Bulimina sp., Eponides sp., Pullenia sp., Uvigerina sp., Trifarina sp., Elphidium (Cribroelphidium) sp., Astrononion sp., Robertinidae, Anomalinoides sp., Melonis sp., Cibicides sp. No planktonic taxa are present.

Uvigerina, Trifarina, Eponides, and Elphidium are the dominant elements in the fauna. Agglutinated specimens are rare. The faunas of Site 272 (30-44, CC) differ in several respects from those investigated in stratigraphically lower sediments (early Miocene) at the adjacent Site 270 . The species diversity at Site 272 is considerably less, and tests are less abundant and are smaller in size. Agglutinated taxa are poorly represented. Taxa present in the upper part of the Site 270 succession, but absent here, include Sphaeroidina, Epistominella, Cassidulinoides, Globocassidulina, Globobulimina, etc. It was suggested in the report for Site 270 that the depth of deposition for early Miocene sediments $(19, \mathrm{CC}$ to $28, \mathrm{CC})$ was probably about 400 500 meters. The $30-44, \mathrm{CC}$ interval in Site 272 indicates deeper depth of deposition, probably somewhere between 500 and 1000 meters.

Unfortunately, the taxa present do not allow a confident age determination to be made. Early Miocene and Pliocene taxa observed at Sites 270 and 273 are missing from the $30, \mathrm{CC}$ to $44, \mathrm{CC}$ interval at Site 272, suggesting perhaps, that this interval lies somewhere in the middle-upper Miocene. A similar age is also suggested by diatoms present.

\section{Nannofossils}

Occasional nannofossil specimens were found in Cores 17-1, 27-1, and 34, CC, but these were not useful for designating ages to the sediments.

\section{Radiolaria}

Most of the sediments contain none or only traces of Radiolaria. The identifiable Radiolaria occur as follows: Sample 11-3, 41-44 cm: traces of poorly preserved Radiolaria (Helotholus vema and Prunopyle titan); Helotholus vema Zone?.

Sample 16-2, 67-71 cm: traces of poorly preserved Radiolaria (Helotholus vema and Prunopyle titan); Helotholus vema Zone?.

Zones assigned to these two levels are doubtful because of the absence of Antarctissa strelkovi, A. denticulata, and $A$. ewingi, which are the most abundant species in the post-Miocene sediments.

\section{Diatoms}

Diatoms are in low abundance but are well preserved except for a barren section between Samples 1-1, $145 \mathrm{~cm}$ through $3, \mathrm{CC}$. Core 1 above $1-1,145 \mathrm{~cm}$ contains the Coscinodiscus lentigenosus Zone. Below 1-1, 145 through $3, \mathrm{CC}$ is essentially barren except for rare occurrences of Actinocyclus ingens in Core 3 . No zonal assignment can be made on this diatom alone. Samples 4-1, $130 \mathrm{~cm}$ through 16-1, $113 \mathrm{~cm}$ contain a portion of the Denticula lauta/Denticula antarctica Zone. Below 16-1, $113 \mathrm{~cm}$ through $17-3$ is a portion of the Denticula antarctica/Coscinodiscus lewisianus Zone. Below 18-1, $70 \mathrm{~cm}$ through Core 38 is unzoned at the present. The assemblage is characterized by Coscinodiscus apiculatus and Aulacodiscus brownii which are thought to extend into the lower Miocene. Diatom abundance is drastically reduced after Core 18 .

\section{Silicoflagellates}

Sediments at this site are either barren or contain very low abundances of silicoflagellates. Most of those specimens examined were well preserved and exhibited the same high degree of intraspecific skeletal variability characteristic of most silicoflagellates found in the sediments of the Ross Sea.

Sample 1-1, 80-132 cm, contains Distephanus quinquangellus and highly ornamented specimens of Distephanus speculum with a wide apical apparatus. Although the present morphotype of Distephanus speculum is common in Matuyama sediments, no age designation is possible due to the lack of assemblage diversity.

Distephanus speculum s.l. is also present in sediments from 14, CC; 18, CC; and 25, CC

Sieved samples from Core $35, \mathrm{CC}$ yielded common to abundant amounts of silicoflagellates of limited diversity. The assemblage at this interval is dominated by Distephanus speculum s.l., but contains one specimen of Mesocena cf. pappii which may indicate an early Miocene age because of its correlative occurrence in the early Miocene at Site 266.

\section{SUMMARY AND CONCLUSIONS}

The sequence of strata cored at Sites 270, 271, and 272 provides much important information on the biostratigraphy and climatic history of this sector of Antarctica and on the depositional history and relative position of the Ross shelf with reference to sea level.

Sediments penetrated at the combined sites total 1120 meters of the approximately 1400 meters representing the entire Oligocene to Recent section. An additional 10.5 meters of basement was cored.

At Site 270, the upper 384 meters consist of glacial marine sediments dating back to the Oligocene. Unconformably, beneath this is less than a meter of calcareous glauconitic sandstone and a similar thickness of carbonaceous sandstone, both of Oligocene age. The carbonaceous sandstone lies on about 25 meters of sedimentary breccia which grades down into a continental basement of marble and calcsilicate gneiss, possibly of early Paleozoic age. The glacial marine sequence is divided 
into two lithologic units, an upper one, 20 meters thick of pebble-bearing, diatomaceous silty clays of Quaternary to late Pliocene age lying unconformably on a lower, more lithified unit ( $364 \mathrm{~m}$ thick) of silty claystone and clayey siltstone with clasts which is Oligocene to early Miocene in age.

Site 271 yielded little information on the late Cenozoic geologic history of the Ross Sea because of the extremely poor recovery (7\%) and early termination (at a total depth of $265 \mathrm{~m}$ ) due to the presence of gaseous hydrocarbons. Most core catchers were jammed or filled with pebbles and cobbles, suggesting that the poor recovery was the result of abundant ice-rafted stones in the sediment. The first gas bubbles were observed in Core 24 at Site 271 , and analyses by gas chromatography showed nitrogen, carbon dioxide, methane, ethane, and ethylene to be present. Although the absolute level of observed concentrations (and thus their significance unknown) was uncertain, caution led to the premature abandonment of the hole. Sediments at Site 271 are apparently uniform silty clays and clayey silts bearing clasts of variable size in relatively large quantities. The measured maximum concentration of clasts is $3 \%-5 \%$ by volume. The age of the sediment ranges from Brunhes (Quaternary) to early Pliocene or questionable late Miocene.

Silty clay and claystone and diatomite, all bearing clasts up to small cobble size, characterize the entire sequence at Site 272. The bottom of the section cored, at 443 meters subbottom, lies about 100 meters above the top of the youngest dipping sequence sampled at Site 270 , while the top of the cored section lies about 100-150 meters below the bottom of the maximum penetration at Site 271. The sediments at Site 272 range in age from $\mathrm{Re}-$ cent to middle Miocene. The youngest lithologic unit at Site 272 consists of at least 18.5 meters of greenish-gray silty clay with amounts of diatoms decreasing and numbers of clasts increasing toward the base. Sand grains occur through Unit 1, in amounts up to $20 \%$. The upper subunit, 1A, resembles topmost strata at Sites 270 and 273 , but here may be substantially thicker, possibly up to 4.5 . Subunit $1 \mathrm{~B}$ is about 18 meters thick and has counterparts at 270,273 , and possibly 271 as well. The age of Unit 1 is Quaternary to early Pliocene or ?late Miocene. Unit 2 is at least 410 meters thick, consists dominantly of diatomaceous silty claystone and silty clay diatomite and is much more lithified than Unit 1 (acoustic velocities at the contact, $\sim 2.0 \mathrm{vs} 1.7 \mathrm{~km} / \mathrm{sec}$ ). Foraminifera occur in the lower 150 meters. Granules and larger clasts up to at least $10 \mathrm{~cm}$ long constitute about $2 \%$ of the unit by volume, but there is considerable variation in abundance.

Clasts throughout the entire glacial marine sequence, represented by the combined sites, are of highly variable types including granites, basalts, quartzites, gneisses, argillites, sandstones, and silty limestones. The entire clast population strongly suggests they were derived from Marie Byrd Land to the east and south and there is no suggestion of any significant change in provenance from Oligocene to Recent.

The greensands underlying the oldest glacial marine sediments (at Site 270) are composed of roughly equal proportions of quartz sand, silt, clay, carbonate, and glauconite. There are only traces of reworked glauconite above this unit, suggesting that the greensand was largely consolidated before the younger beds were deposited. Vaguely defined horizontal lamination occurs in the greensand, and burrows filled with coarse detritus were also observed. The contact between the greensand and the underlying carbonaceous sandstone was not preserved in the cores.

Clasts in the sedimentary breccia at Site 270 are angular or subangular and consist mainly of impure marble and calcsilicate gneiss although leucogranite, vein quartz, and other rock types are also present. Clast size, angularity and lack of sorting suggest that the breccia is a fossil talus deposit. The upper 3 meters of the breccia is extensively altered and is interpreted as a buried regolith.

The breccia rests nonconformably on gray, foliated marble and calcsilicate gneiss, which represents the seismic basement with compressional wave velocities of $>4 \mathrm{~km} / \mathrm{sec}$. On the basis of its similarity to the Koettlitz Marble and possible equivalence to unmetamorphosed Cambrian limestones of the Transantarctic Mountains, a highly tentative age of early Paleozoic is assigned to the basement rocks at Site 270.

The dominant mode of sedimentation at combined Sites 270, 271, and 272 has been one of ice-rafting under marine conditions from late Oligocene to Recent. Although extensive reworking is not obvious, subtle variations in lithologies, stratification, as well as strong changes in diatom content and lithification indicate the sedimentary environment changed significantly several times, no doubt reflecting minor episodes in the advance and retreat of shelf ice within the Ross embayment.

By far the most significant glacial event recorded in the area is manifested by the pronounced angular unconformity shown on the seismic records (Figures 2 and 3 ) and the stratigraphic hiatus clearly recorded at Sites 270 and 272.

This unconformity which truncates the dipping sedimentary sequences on a regional scale appears to lie between Units 1 and 2 at Site 272, and the maximum hiatus represented is from early Pliocene to late Miocene. The unconformity is thought to represent a major erosional surface caused by grounded shelf ice when it advanced well north of its present position. The timing of this event is crucial in reconstructing the significant factors in the glacial history of this area and perhaps the entire continent. Considering all sites on this traverse, the oldest confidently dated strata above the unconformity are (?)early to middle Gauss in age (Site 270). This sediment includes Globocassidulina biora (Crespin) which occurs unreworked only below the younger unconformity recognized by Fillon (1972), but a full age range for this species is not known.

On the seismic profiles the gently dipping $\left(\sim 1^{\circ}\right)$ sequence may be truncated at Site 271 by either of the two nearly horizontal reflecting surfaces at 0.07 and $0.14 \mathrm{sec}$ reflection time (see Figure 2). The lowest of these reflectors apparently passes into a conformable sequence to the northeast of Site 271. Neither surface could be confidently identified as the unconformity surface either 
paleontologically or by changes in sediment character. The upper horizon occurs at a depth of about 70 meters (Core 5), and must be younger than the dated sediments in Core 9 (Gauss/Gilbert = lower Pliocene), and older than the Brunhes sediments in Core 1. The only semilithified sediments recovered at Site 271 occur in Core 5; additionally, acoustic velocities are relatively high in Core $5(\sim 2.0 \mathrm{~km} / \mathrm{sec})$. This upper horizon may possibly represent the unconformity recognized by Fillon (1972) which is dated as late Gauss-early Matuyama. According to Fillon, clasts are larger and more abundant and sediments are more consolidated in Gauss sediments below his unconformity than in the overlying sequence, but this relationship was unrecognized at Site 271. The lower surface identified on the seismic profiles lies at a depth of about 135 meters (Core 12). Below this level core recovery decreased significantly, concurrently with an increase of large clasts in core catchers. The age of the sediments at this level fall within the range Gauss/Gilbert-early Pliocene.

The near coincidence of age above and below the inferred unconformity surface at Site 271 and to a lesser extent Site 272 indicates that truncation of the dipping sequence took place in the very short interval somewhere between the early Gilbert and the middle Gauss ( 3-5 m.y. B.P.). Within this short interval a major glacial pulse occurred comprised of a substantial increase in the northern limit of grounded shelf ice and followed by a rapid retreat of the ice shelf edge to a position similar to that of today. Independent studies on piston cores (Ciesielski and Weaver, 1974) strongly suggest a major interglacial in the Southern Ocean during the period $4.30-3.95$ m.y. B.P. In the absence of better stratigraphic control on the Ross Sea sites, it is reasonable to assume the inferred major advance of a grounded Ross ice shelf immediately preceded the above interglacial and implies an age of about 4.5 to 5.0 m.y. for the event.

The inferred age of about 25 m.y. of the basal glacial marine sequence at Site 270 (Allis et al., this volume) and the K-Ar date of 26 m.y. on the preglacial greensand also at Site 270 (McDougall, pers. comm.) establishes the inception of major glaciation in the Ross embayment at mid-late Oligocene.

Regionally, the generalized sequence of the eastern Ross Sea (see Figure 3) is as follows (based on Fillon [1972] and DSDP, Leg 28, results):

\begin{tabular}{|c|c|}
\hline Thickness & Sediment Type and Age \\
\hline \multirow[t]{2}{*}{$0-<10 \mathrm{~m}$} & $\begin{array}{l}\text { Glacial marine, reworked and with few clasts. } \\
\text { Recent-early Matuyama (Subunit } 1 \mathrm{~A} \text { at } \\
\text { Sites } 270,272 \text { ) }\end{array}$ \\
\hline & Unconformity. Early Matuyama-late Gauss \\
\hline \multirow[t]{2}{*}{$<30 \mathrm{~m}$ typically } & $\begin{array}{l}\text { Glacial marine, abundant clasts. Late Gauss- } \\
\text { middle Gauss (?) (Subunit 1B at Sites 270, 272) }\end{array}$ \\
\hline & $\begin{array}{l}\text { Angular unconformity. Hiatus: Early Gilbert- } \\
\text { middle Gauss }\end{array}$ \\
\hline \multirow[t]{2}{*}{$\sim 1350 \mathrm{~m}$} & $\begin{array}{l}\text { Glacial marine, soft to lithified. Early Gilbert- } \\
\text { Oligocene (Unit } 2 \text { at Sites } 271,272,270 \text { ); } \\
\text { Gradual subsidence from late Oligocene } \\
\text { to mid-Miocene. }\end{array}$ \\
\hline & Unconformity (?) \\
\hline
\end{tabular}

\begin{tabular}{ll}
$\sim 2 \mathrm{~m}$ & $\begin{array}{l}\text { Greensand and carbonaceous sand. Oligocene } \\
\text { (Units } 3 \text { and } 4 \text { at Site 270) (littoral conditions } \\
\text { in relatively temperate environment) }\end{array}$ \\
$\sim 20 \mathrm{~m}$ & $\begin{array}{l}\text { Sedimentary breccia. Oligocene (?) (Unit 5, } \\
\text { Site 270) }\end{array}$ \\
\hline
\end{tabular}

Foraminiferal faunas from portions of Unit 2 are of very low diversity (up to nine species per sample) and may reflect relatively cold conditions in this portion of the middle Miocene and paleoecological studies suggest depositional depths of 500-1000 meters.

Paleoecological studies of benthonic foraminifera indicate a general deepening of Site 270, from littoral conditions at the time of deposition of the Oligocene carbonaceous sandstone to about 500 meters depth immediately below the top of the early Miocene section ( $\sim 165 \mathrm{~m}$ subbottom). If such conditions do not reflect strictly local tectonism near Site 270 , the initial deepening may mark the time at which isostatic loading of the continent by the ice sheet depressed the continental shelf to its present anomalous depth of about 800 meters and further suggests that the major isostatic response to such loading was complete by middle Miocene.

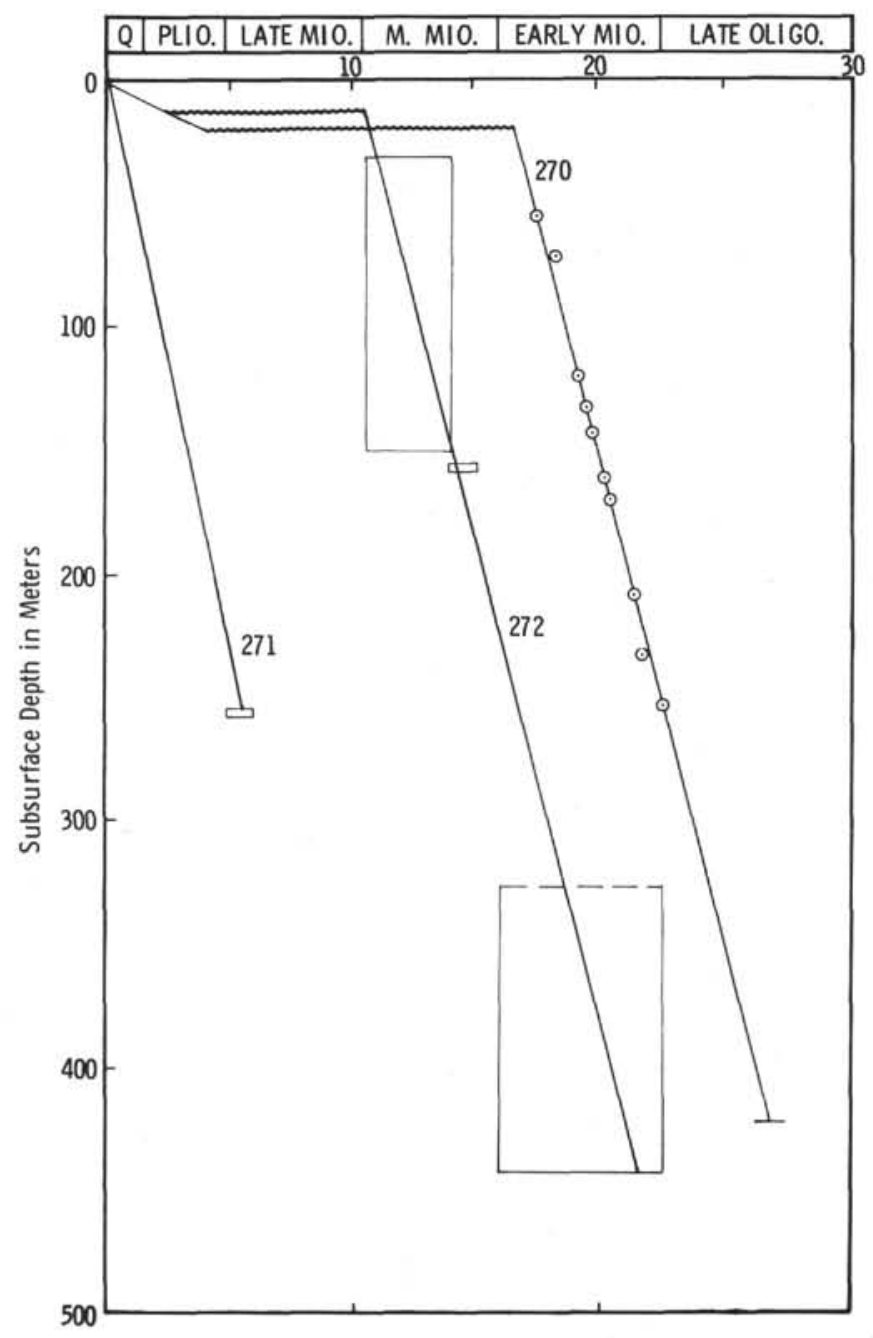

Figure 10. Age vs. depth at Sites 270, 271, and 272. 
The presence of a continental-type basement terrane at Site 270 in the central Ross Sea is one of the most significant results of Leg 28 . Any hypothesis for the tectonic development of the Ross Sea embayment must now satisfy this major constraint. The nearest known rocks of similar lithology belong to the Koettlitz Marble in the vicinity of McMurdo Sound. The Koettlitz has been correlated with fossiliferous Cambrian limestones in the central Transantarctic Mountains, and the carbonate rocks at Site 270 may also be Cambrian in age. If so, the depositional basin of these Cambrian limestones is much wider than formerly known.

\section{REFERENCES}

Benedek, P. N., 1972. Phytoplankton aus dem Mittel und Oberoligozan von Tonisberg (Niederrheingebiet): Palaeontographica B, v. 137, p. 1-100.

Cranwell, L. M., Harrington, H. J., and Speden, I. G., 1960. Lower Tertiary microfossils from McMurdo Sound, Antarctica: Nature, v. 186, p. 700-702.

Ciesielski, P. F. and Weaver, F. M., 1974. Early Pliocene temperature changes in the Antarctic seas: Geology, v. 2, p. 511 .
Fillon, R. H., 1972. Late Cenozoic geology, paleooceanography and paleoclimatology of the Ross Sea, Antarctica: Ph.D. Thesis, University of Rhode Island.

Greenwood, R. 1973. Cristobalite: its relationship to chert formation in selected samples from the Deep Sea Drilling Project: J. Sediment. Petrol., v. 43, p. 700-708.

Heitlein, L. G., 1969. Fossiliferous boulder of early Tertiary age from Ross Island, Antarctica: Antarctic J. U.S., v. 4, p. 199-201.

Houtz, R., and Davey, F. J., 1973. Seismic profiler and sonobuoy measurements in Ross Sea, Antarctica: J. Geophys. Res., v. 78, p. 3448-3468.

Mclntyre, D. J. and Wilson, G. J., 1966. Preliminary palynology of some Antarctic Tertiary erratics: New Zealand J. Bot., v. 4, p. 315-321.

Speden, 1. G., 1962. Fossiliferous Quaternary marine deposits in the McMurdo Sound region, Antarctica: New Zealand J. Geol. Geophys., v. 5, p. 746-774.

Webb, P. N. and Neall, V. E., 1973. Cretaceous foraminifera from Quaternary deposits in Taylor Valley, Victoria Land: SC'AR/Oslo.

Wilson, G. J., 1967. Some new species of lower Tertiary dinoflagellates from McMurdo Sound, Antarctica: New Zealand J. Botany., v. 5, p. 57-83. 


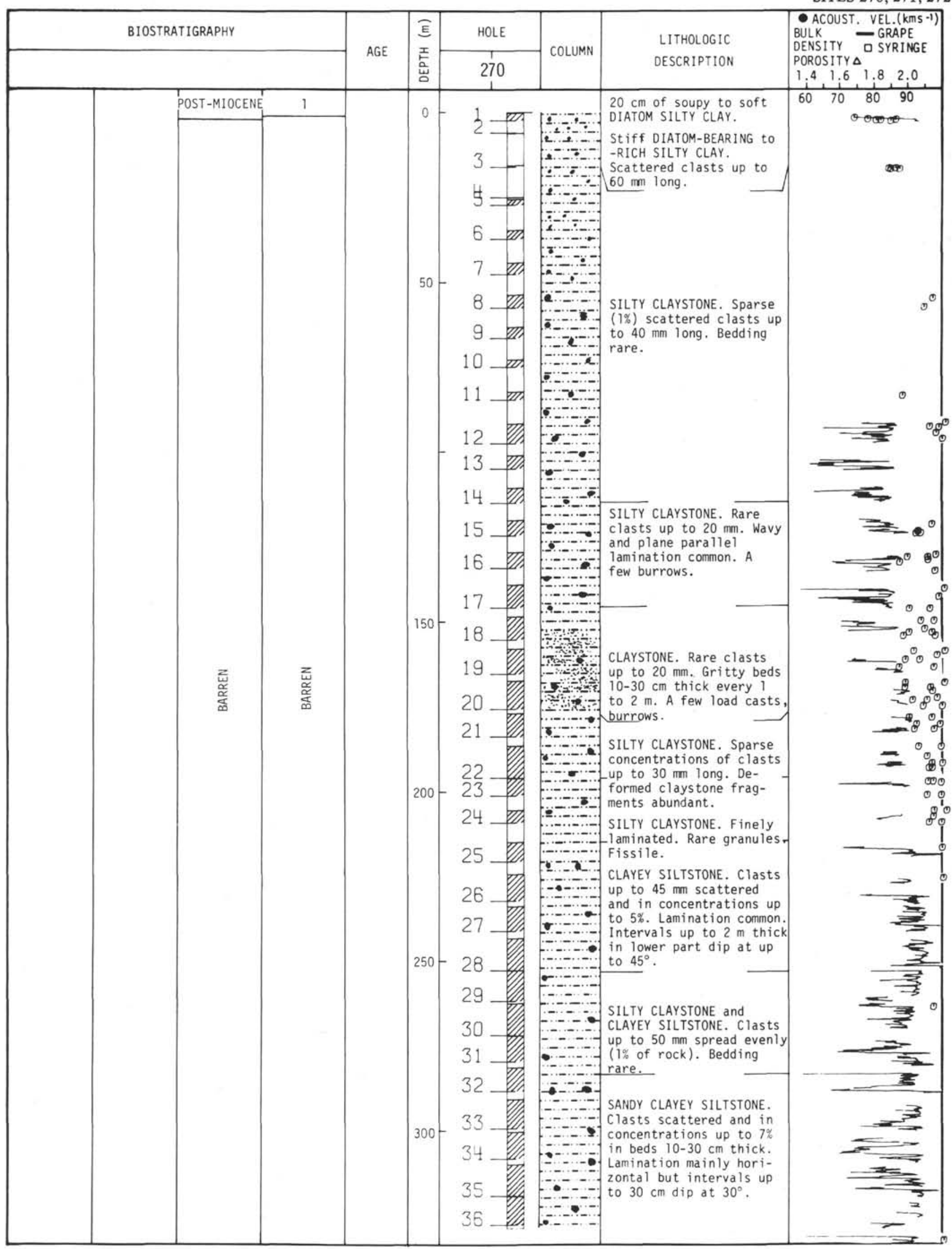

Figure 10. Graphic hole summary, Site 270. 


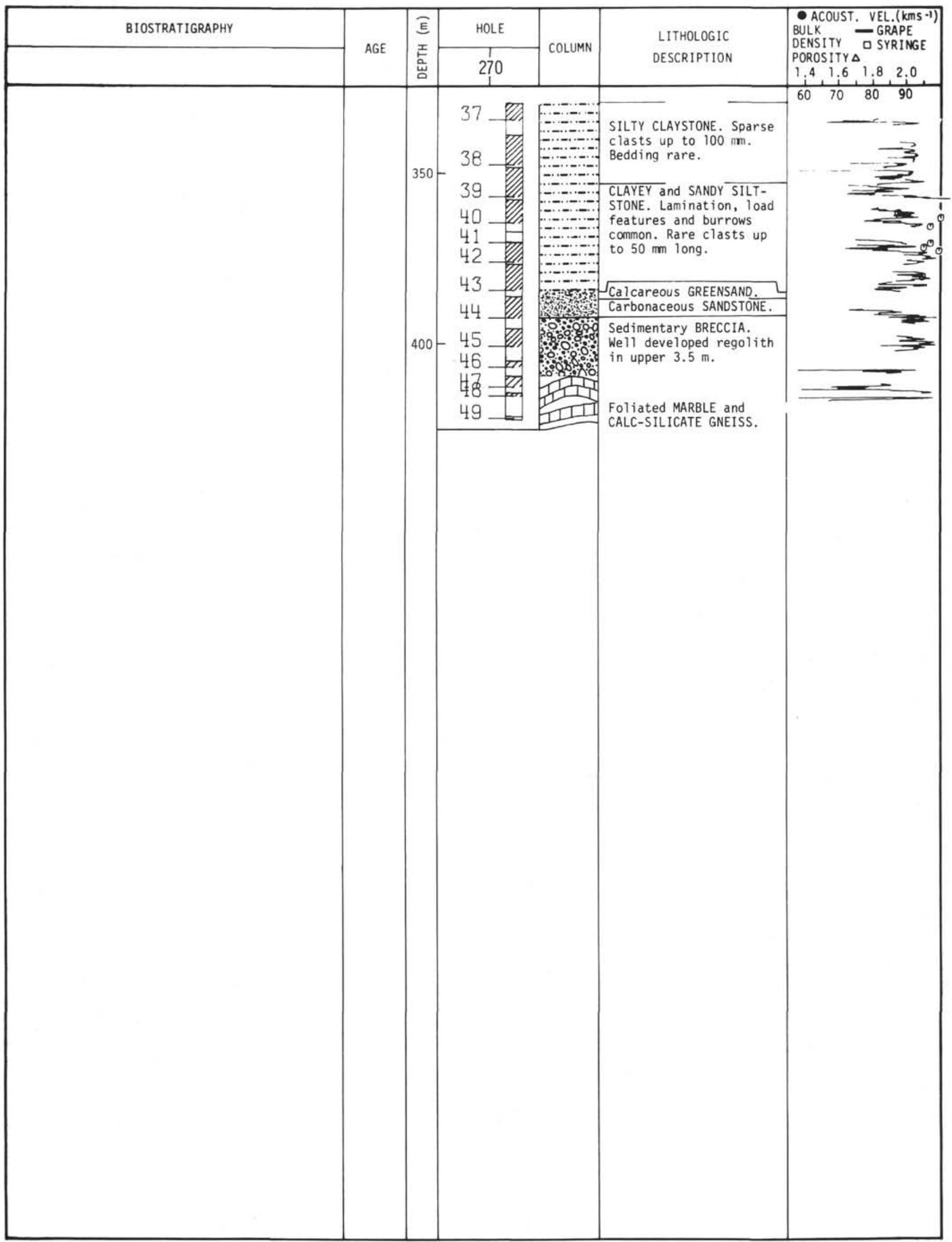

Figure 10. (Continued). 


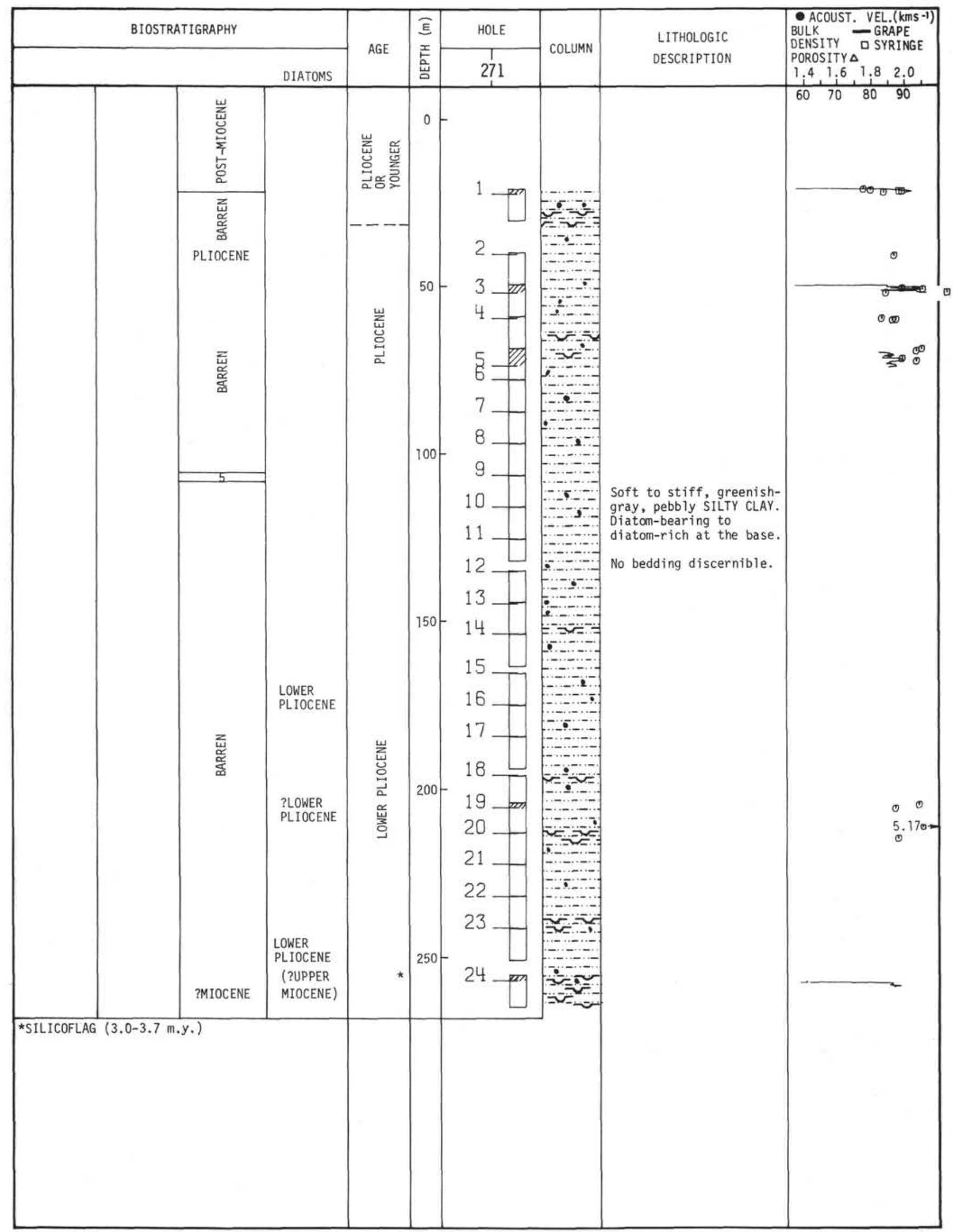

Figure 11. Graphic hole summary, Site 271. 


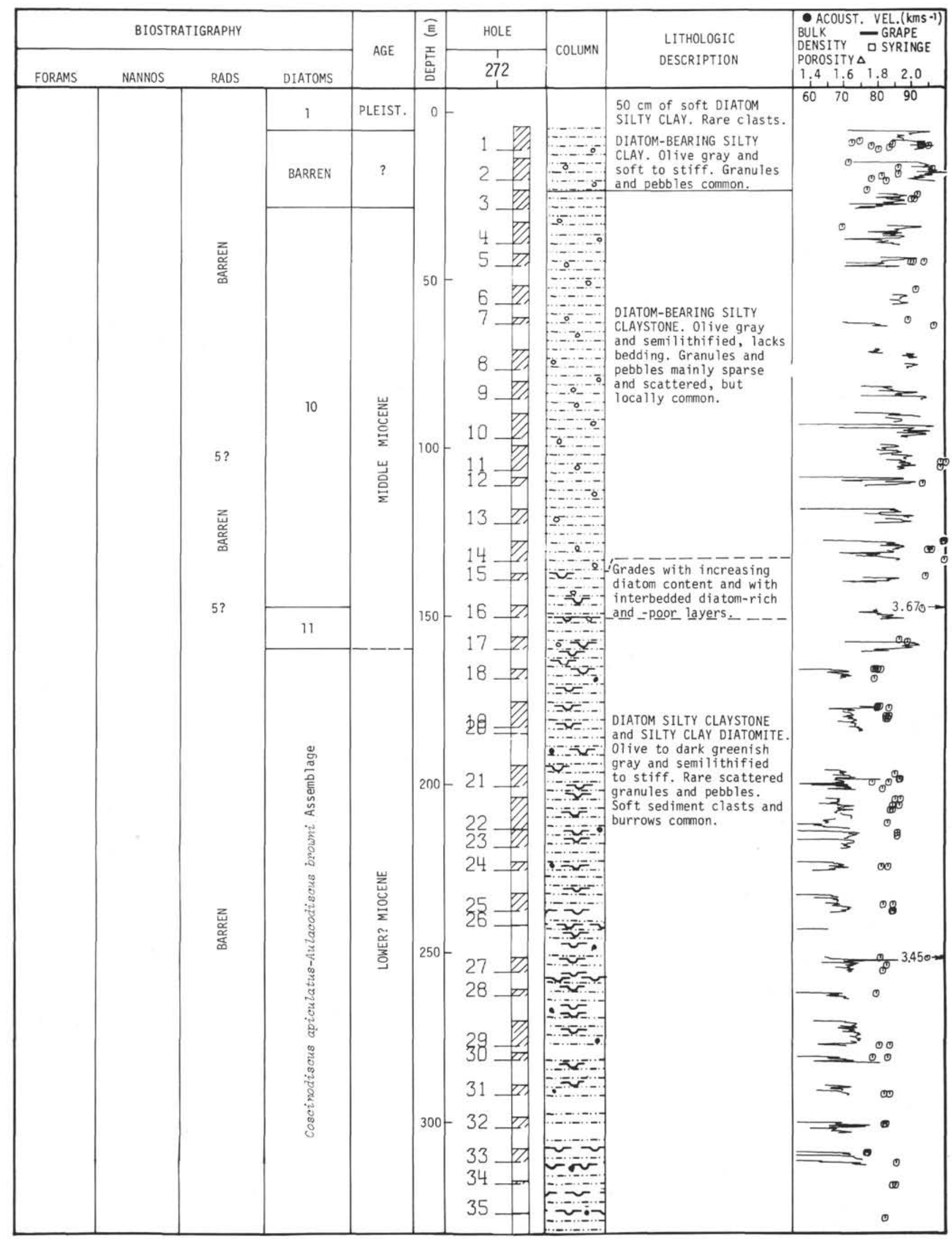

Figure 12. Graphic hole summary, Site 272. 
SITES 270, 271, 272

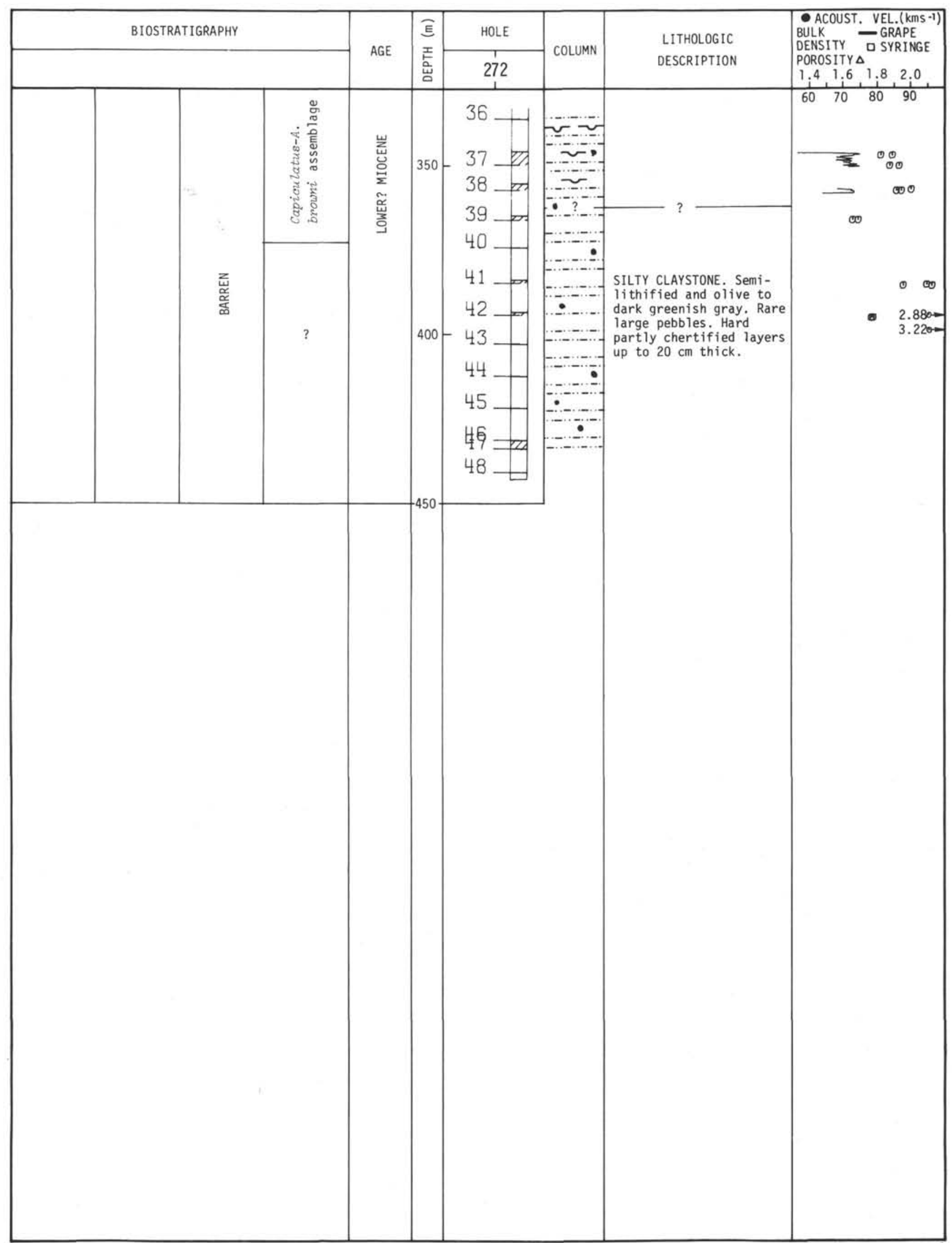

Figure 12. (Continued). 

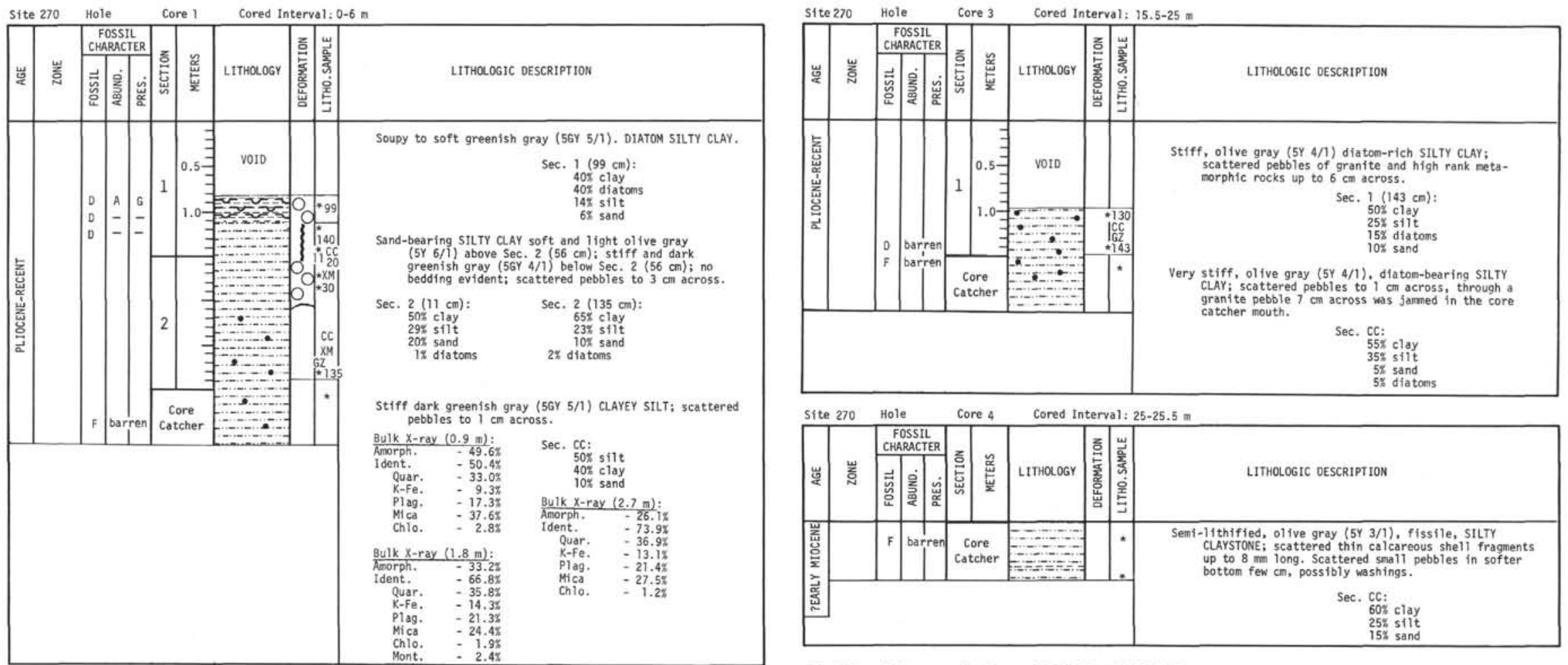

\begin{tabular}{|c|c|c|c|c|c|c|}
\hline ite & & Hole & Core 2 & Cored Int & terval: 6 & \\
\hline ¿ & 狋 & 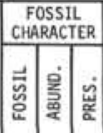 & 递 & LITHOLOGY & 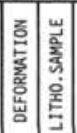 & LITHOLOGIC DESCRIPTION \\
\hline 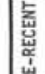 & & $\begin{array}{ll}0 & \text { barren } \\
F & \text { barren } \\
\end{array}$ & \begin{tabular}{|c} 
core \\
Catcher
\end{tabular} & $\therefore$ & * & $\begin{array}{l}\text { Soft. light olive gray (5Y } 5 / 1) \text { diatom-bearing SITYY CLAY; } \\
\text { scattered peebles up to } 2 \mathrm{~cm} \text { areas. }\end{array}$ \\
\hline
\end{tabular}

\begin{tabular}{|c|c|c|c|c|c|c|}
\hline & & Hole & core 4 & ed In & : & \\
\hline 岁 & 訔 & 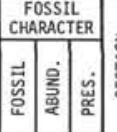 & 总产总 & LITHOLOGY & 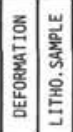 & LITHOLOGIC OESCRIPTION \\
\hline - l- & & $F$ barren & \begin{tabular}{|c|} 
core \\
catcher
\end{tabular} & $=$ & * & 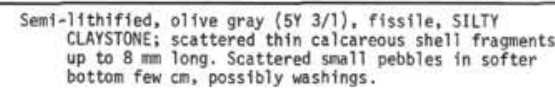 \\
\hline ญ & & & & & & $\begin{array}{r}\text { Sec. cc: } \\
600 \text { clay } \\
255 \text { sit } \\
15 \% \\
5 n d \\
\end{array}$ \\
\hline
\end{tabular}

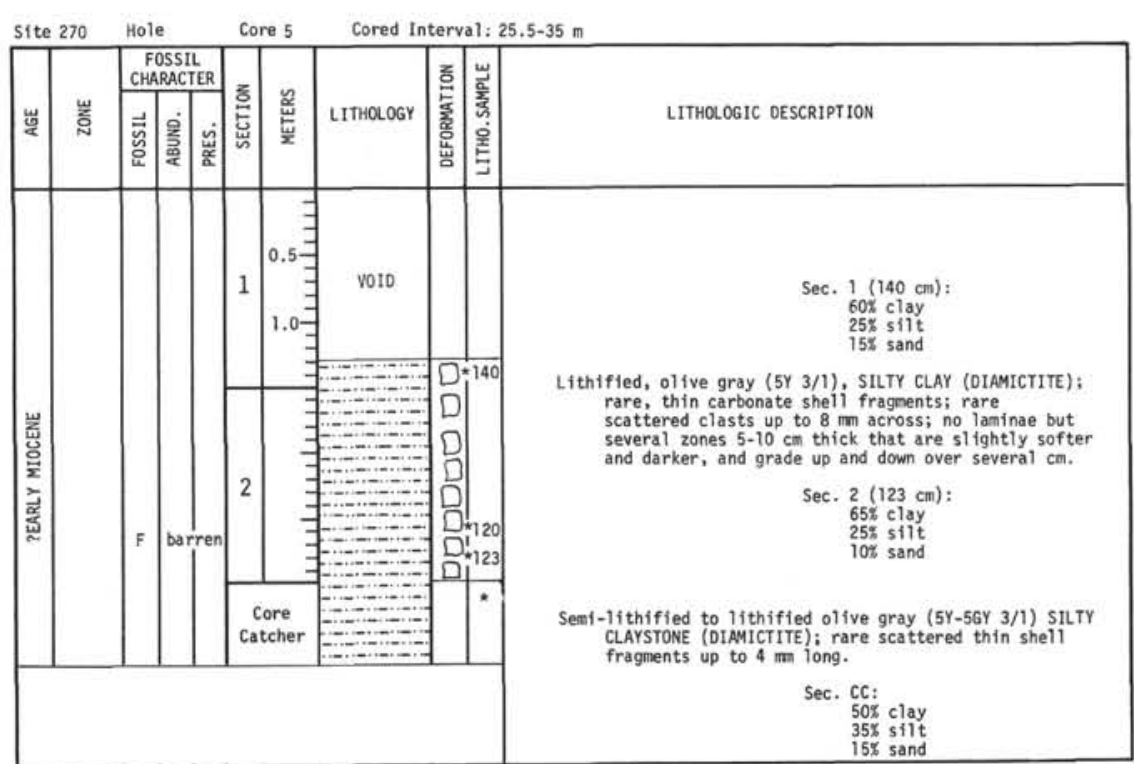

Explanatory notes in Chapter 1 

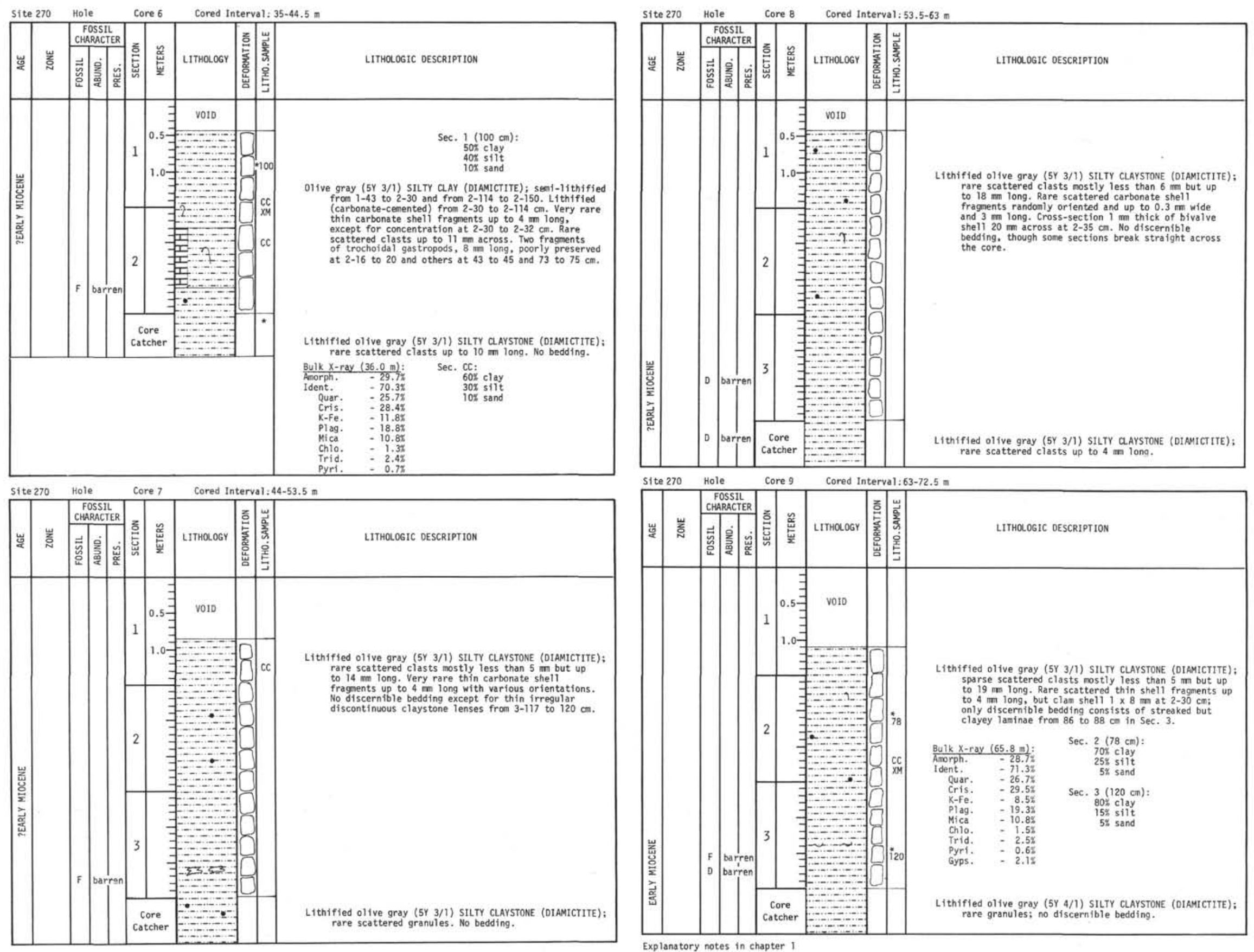

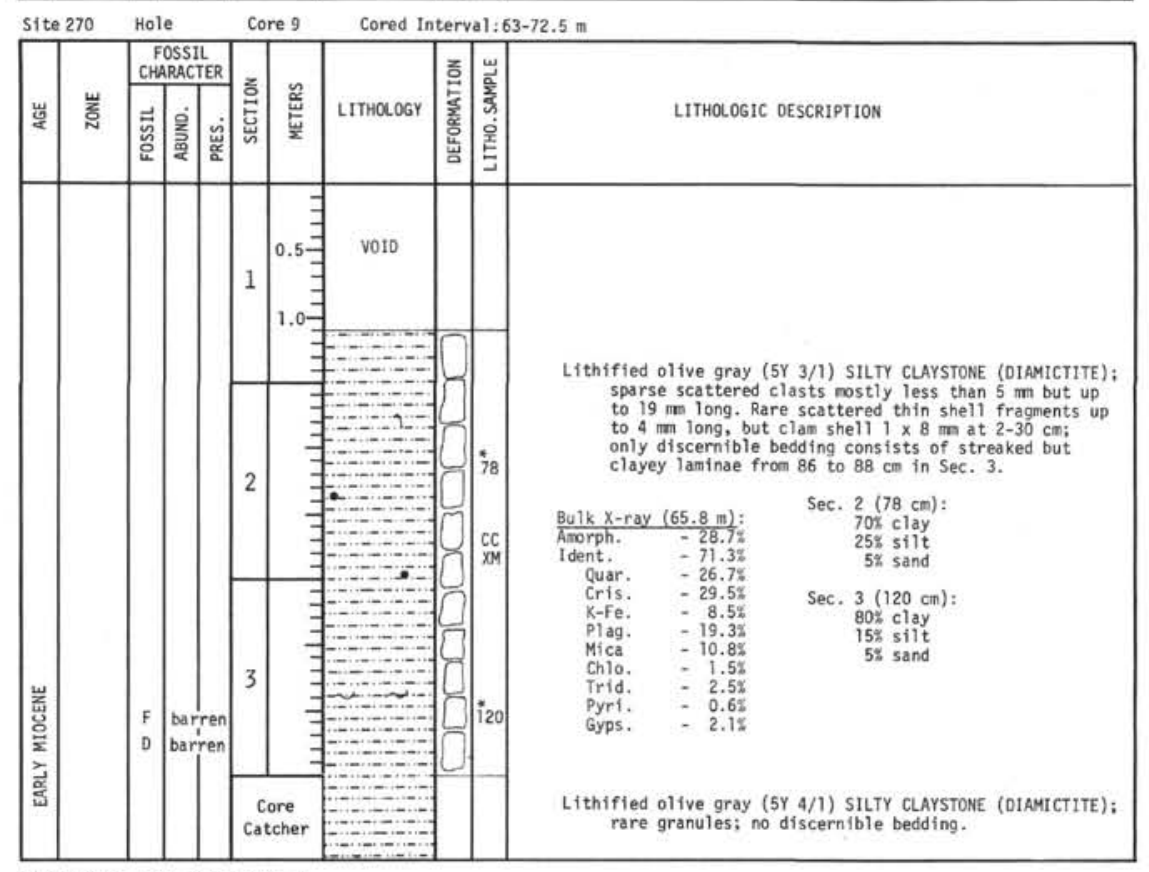



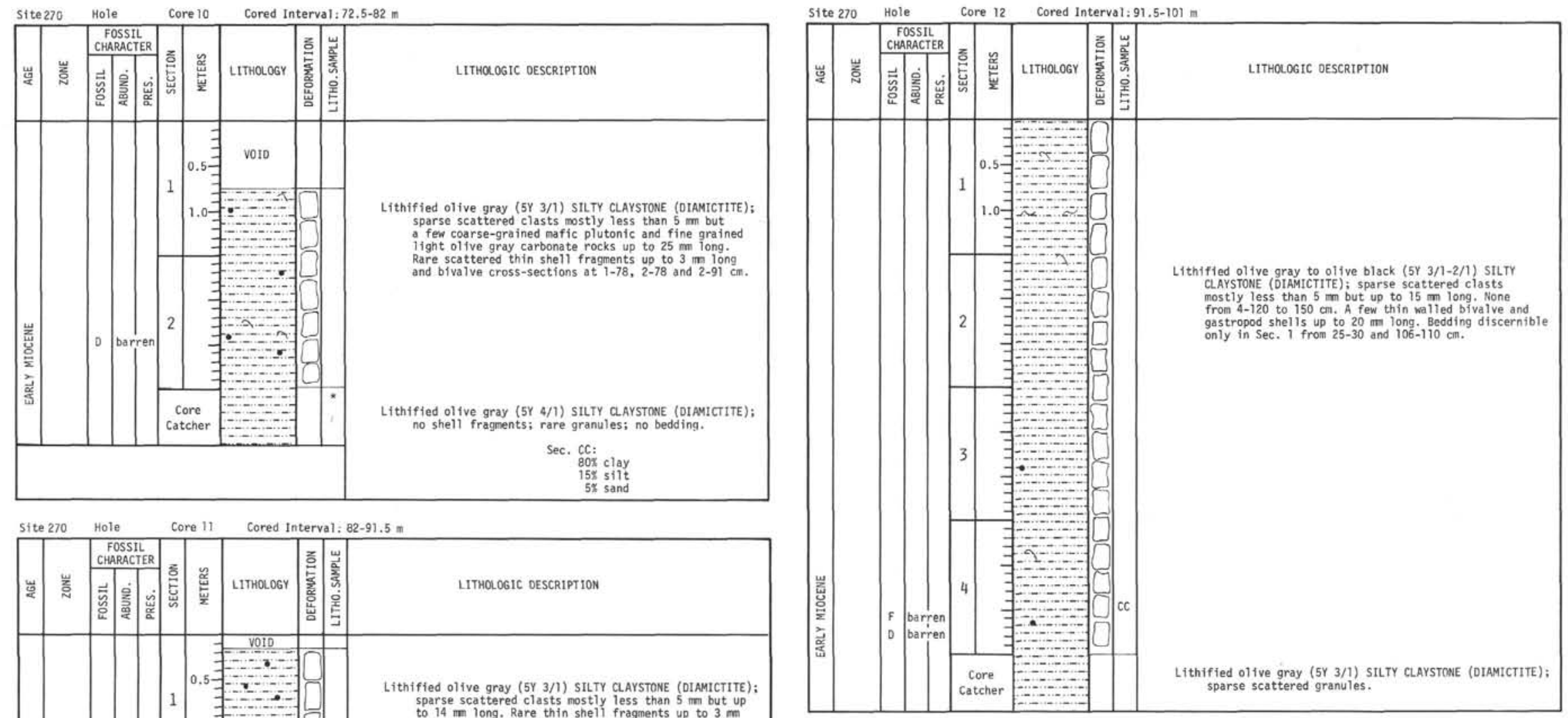

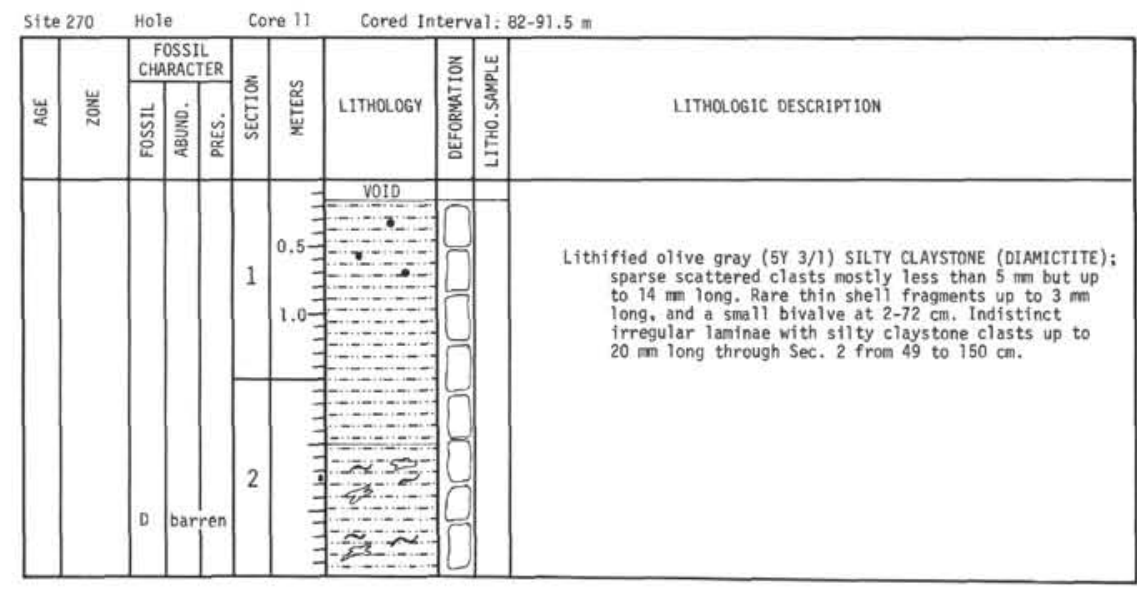

Explamatory notes in chapter 1 


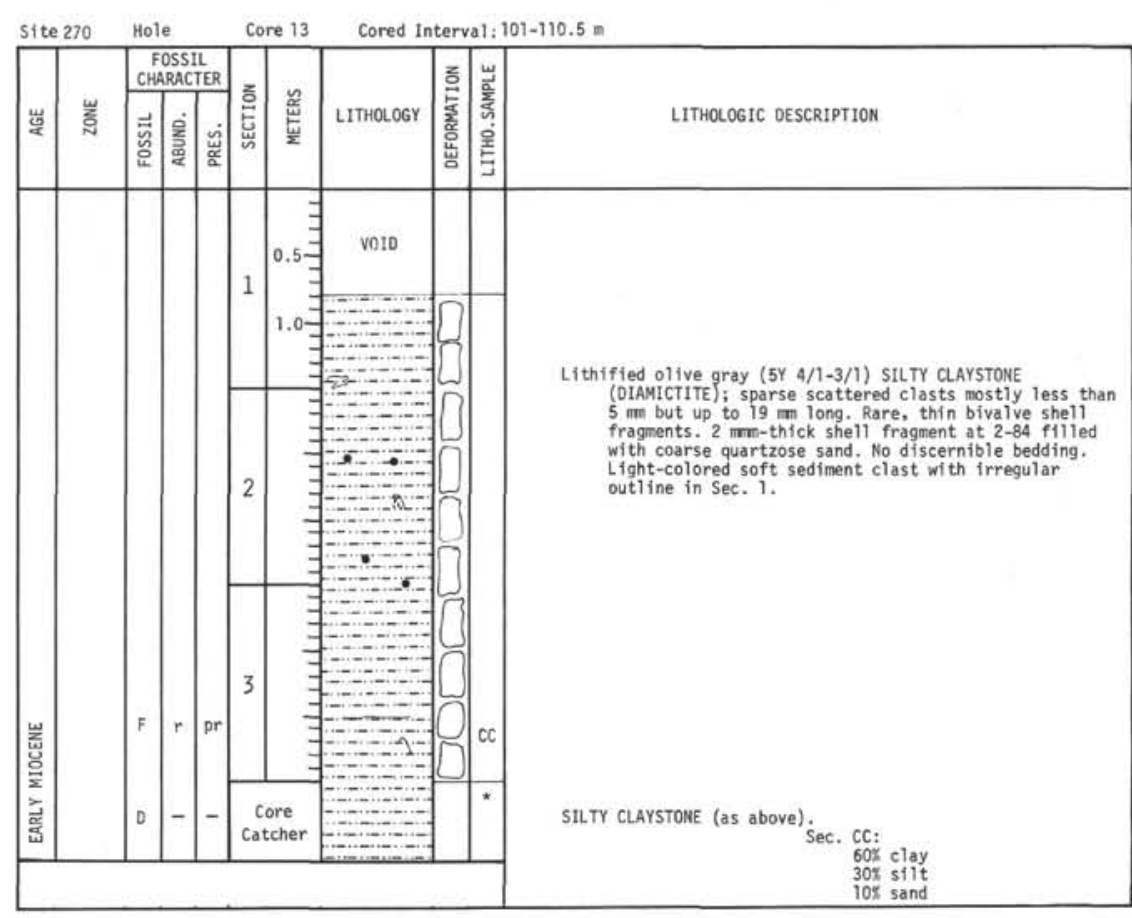

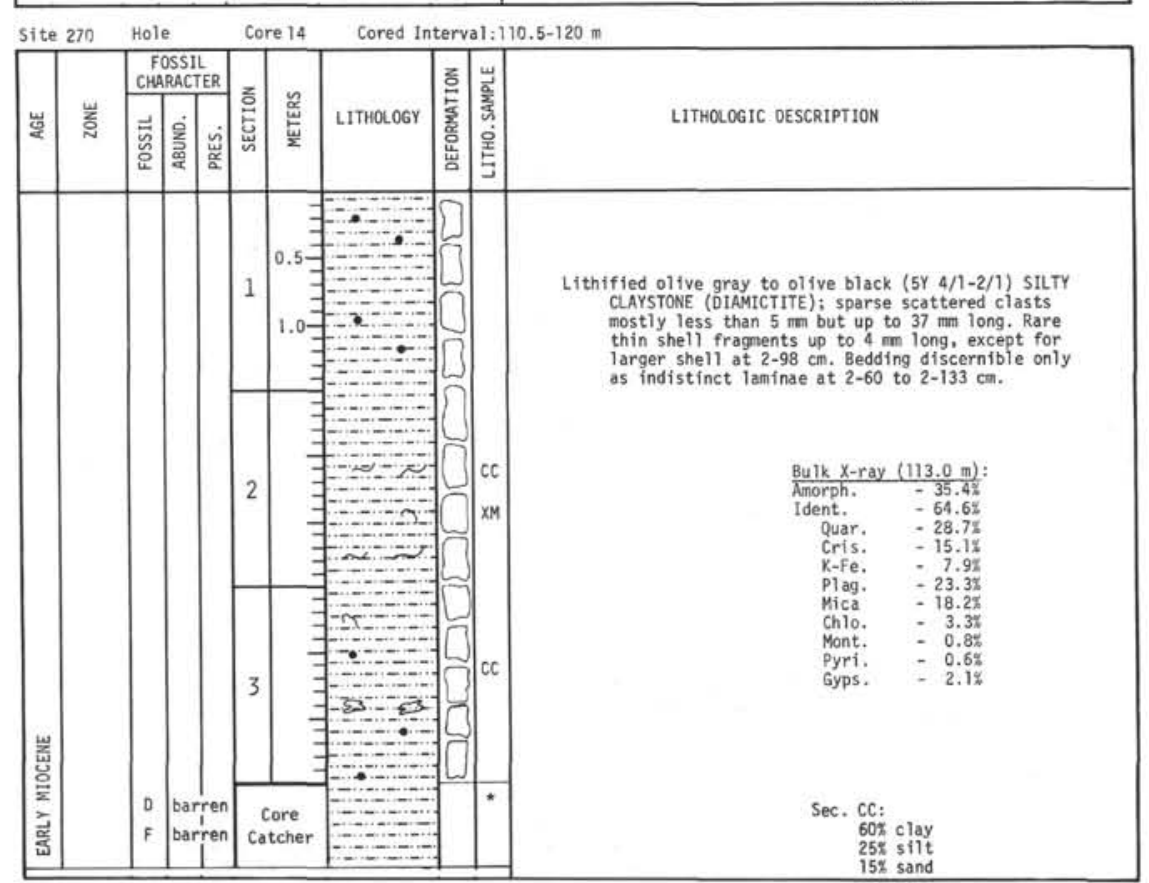

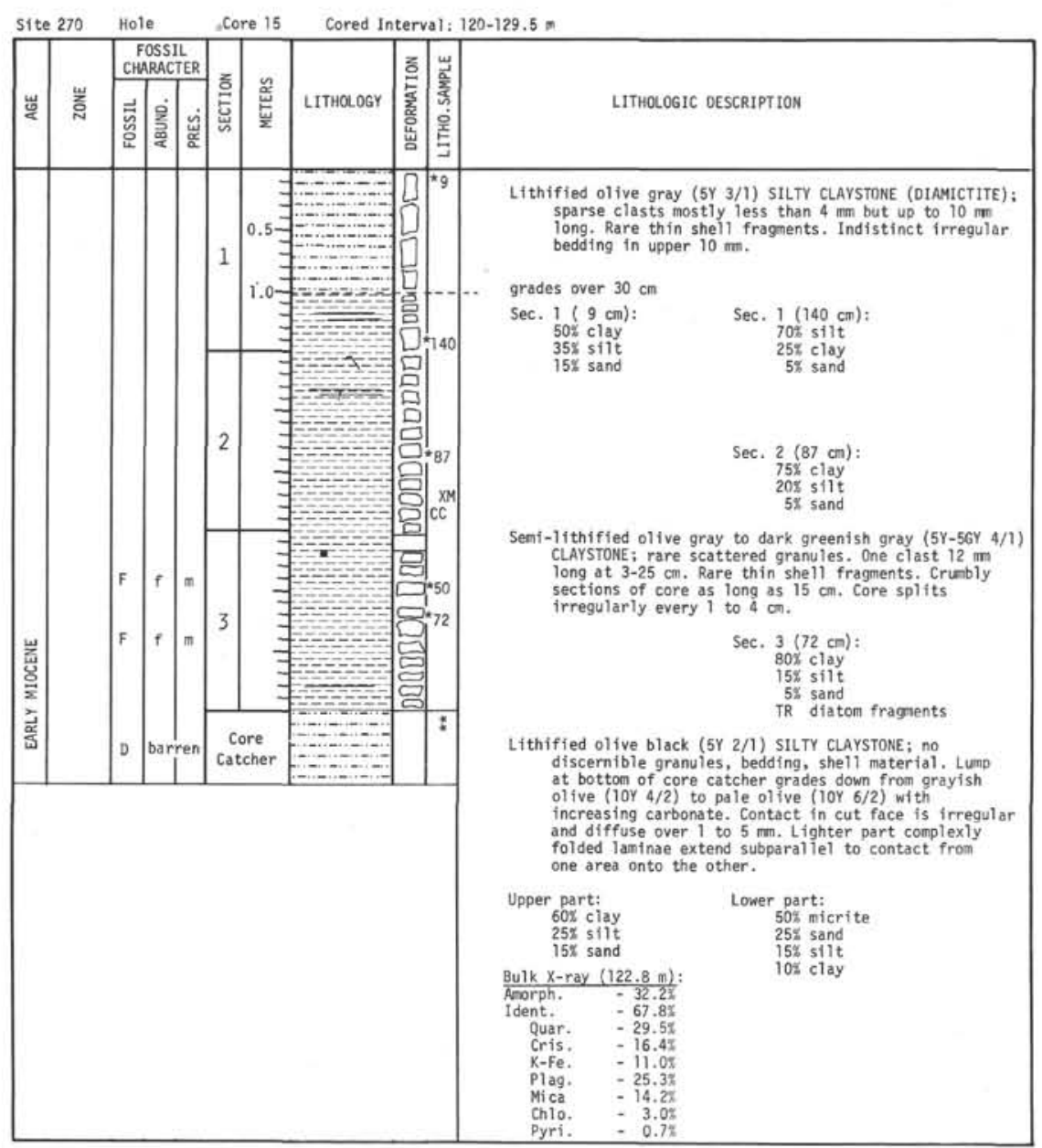

Explanatory notes in chapter 1 

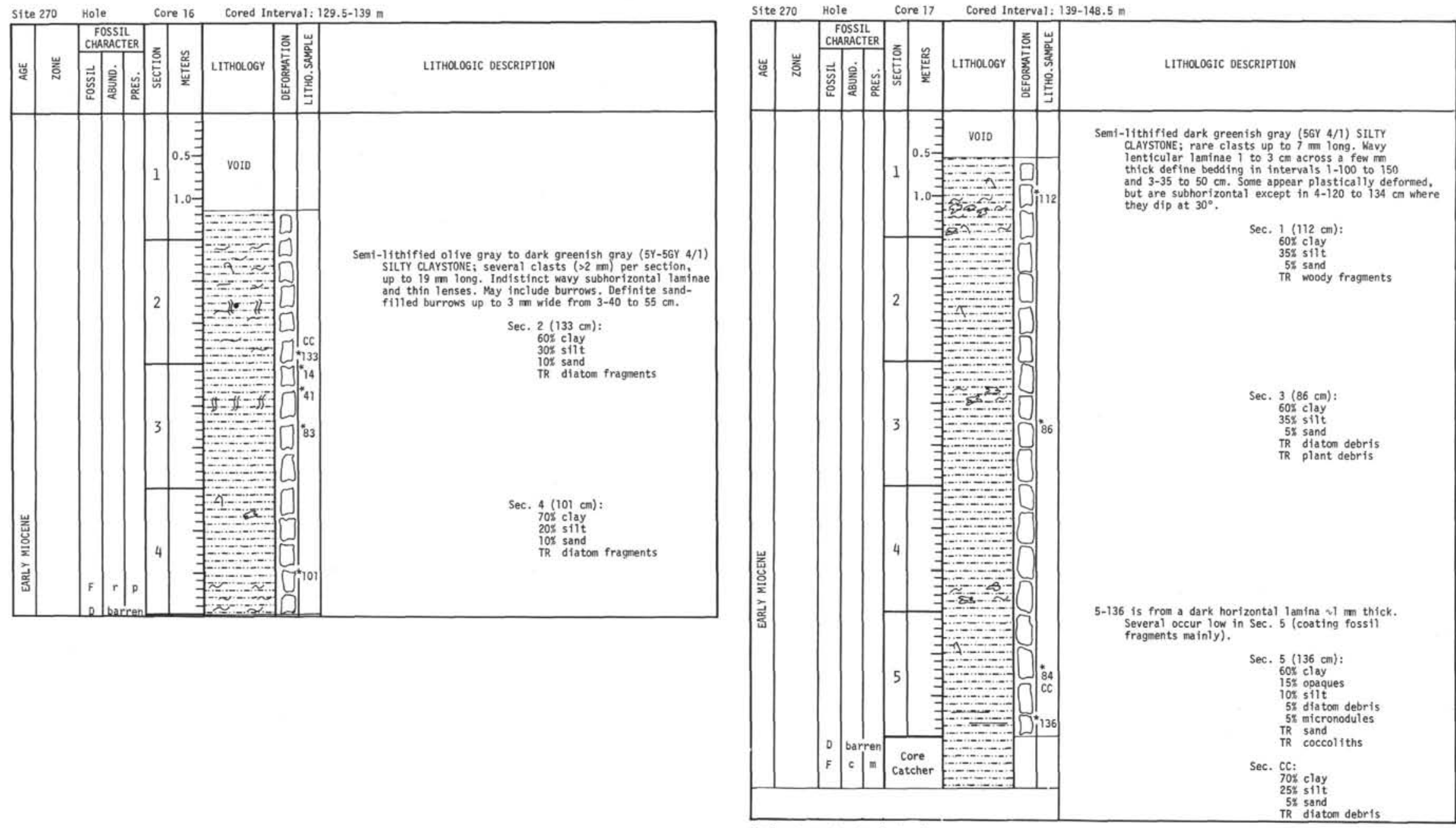

Explanatory notes in chapter 1 


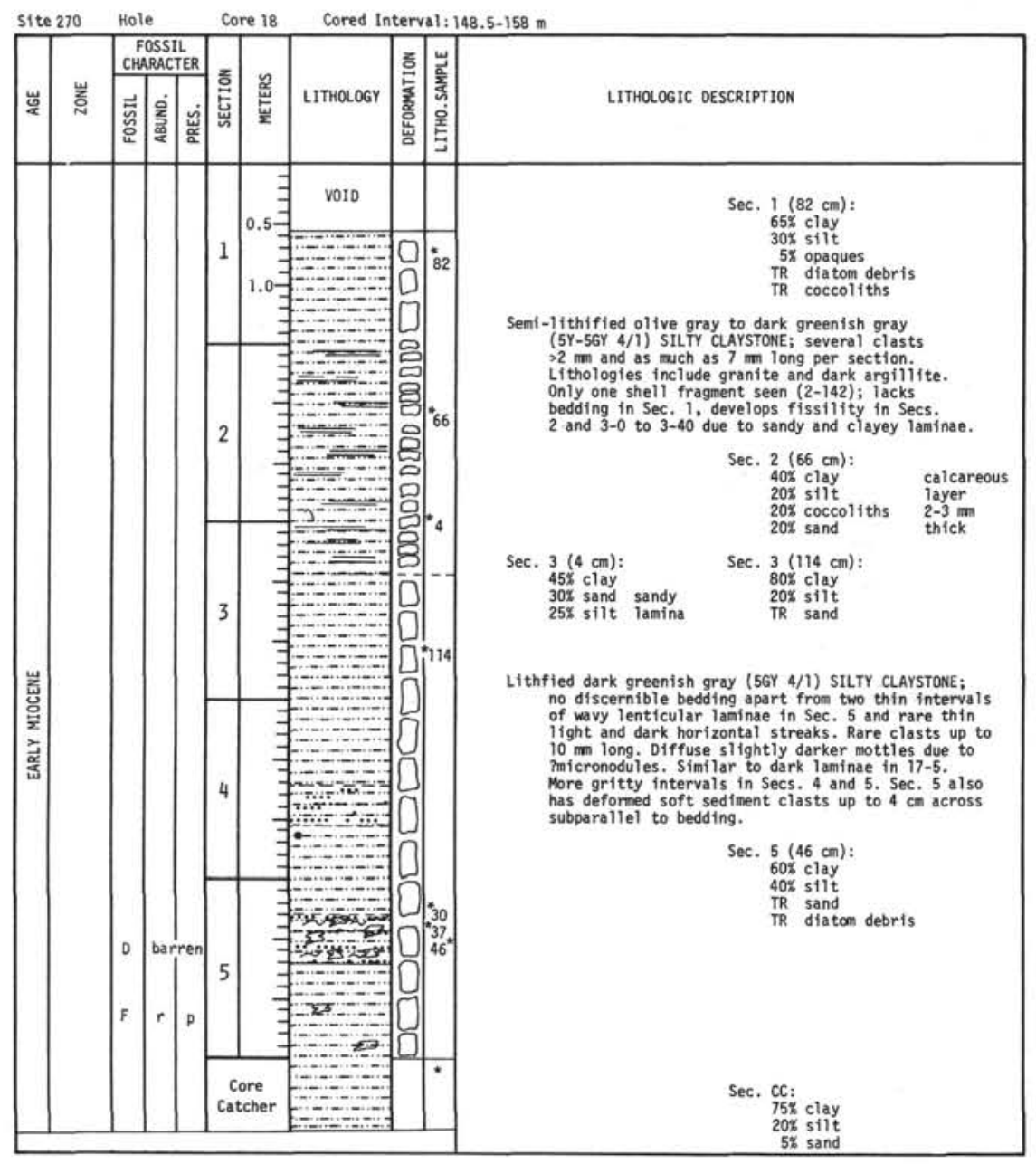

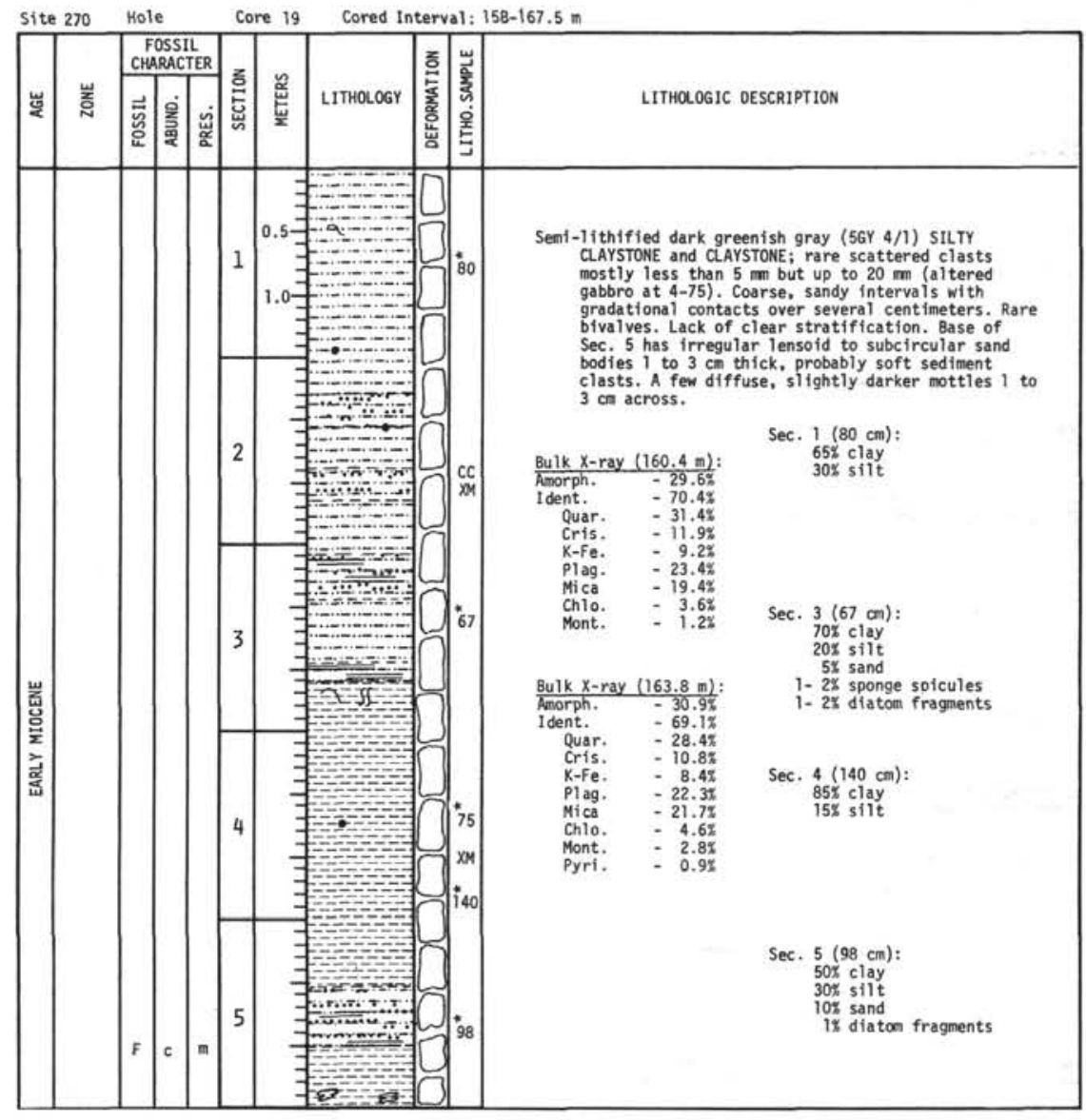

Explanatory notes in chapter - 


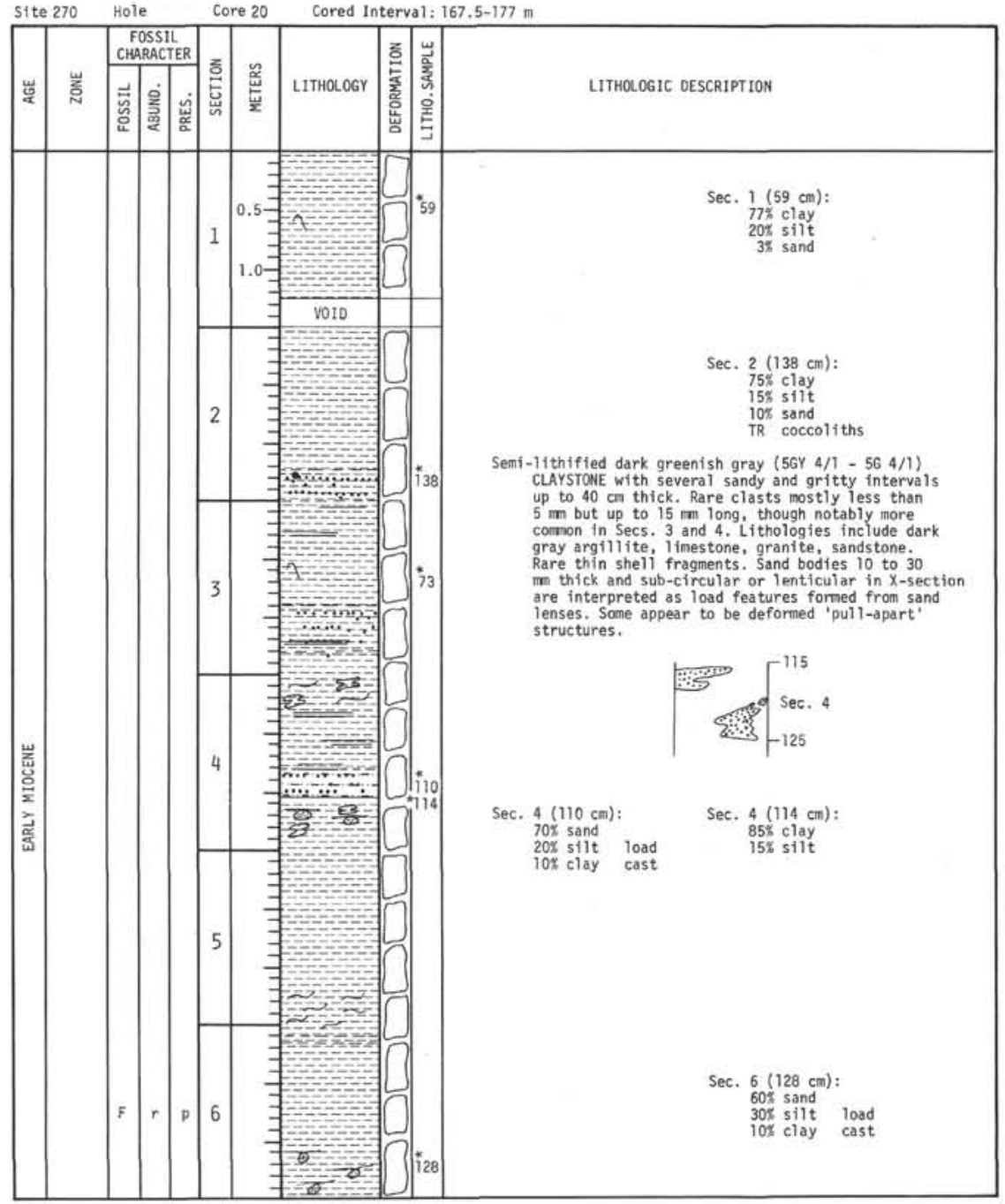

\begin{tabular}{|c|c|c|c|c|c|c|c|c|}
\hline | & 訔 & \begin{tabular}{|c|c} 
F \\
cha \\
$\overrightarrow{5}$
\end{tabular} & 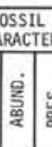 & $\sqrt{\frac{1}{2}}$ & 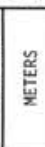 & LITHOLOGY & 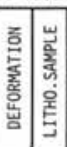 & LITHOLOGIC OESCRIPTION \\
\hline 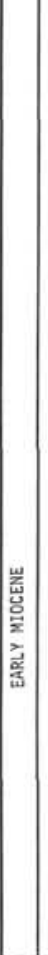 & & $\mathrm{F}$ & & $m 5$ & & \begin{tabular}{c|c|}
0 \\
0 \\
0
\end{tabular} & 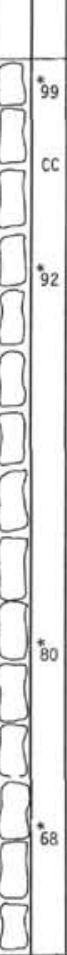 & 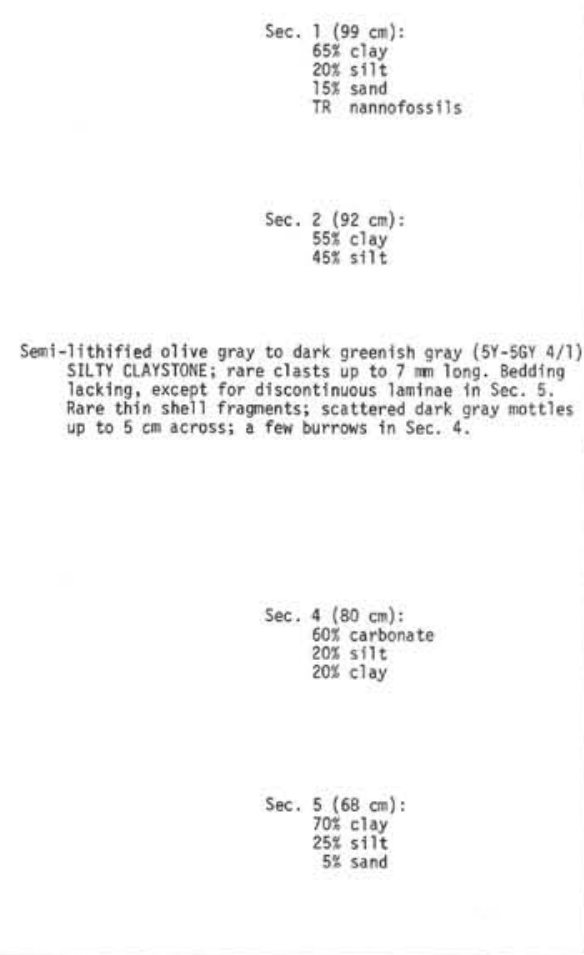 \\
\hline
\end{tabular}




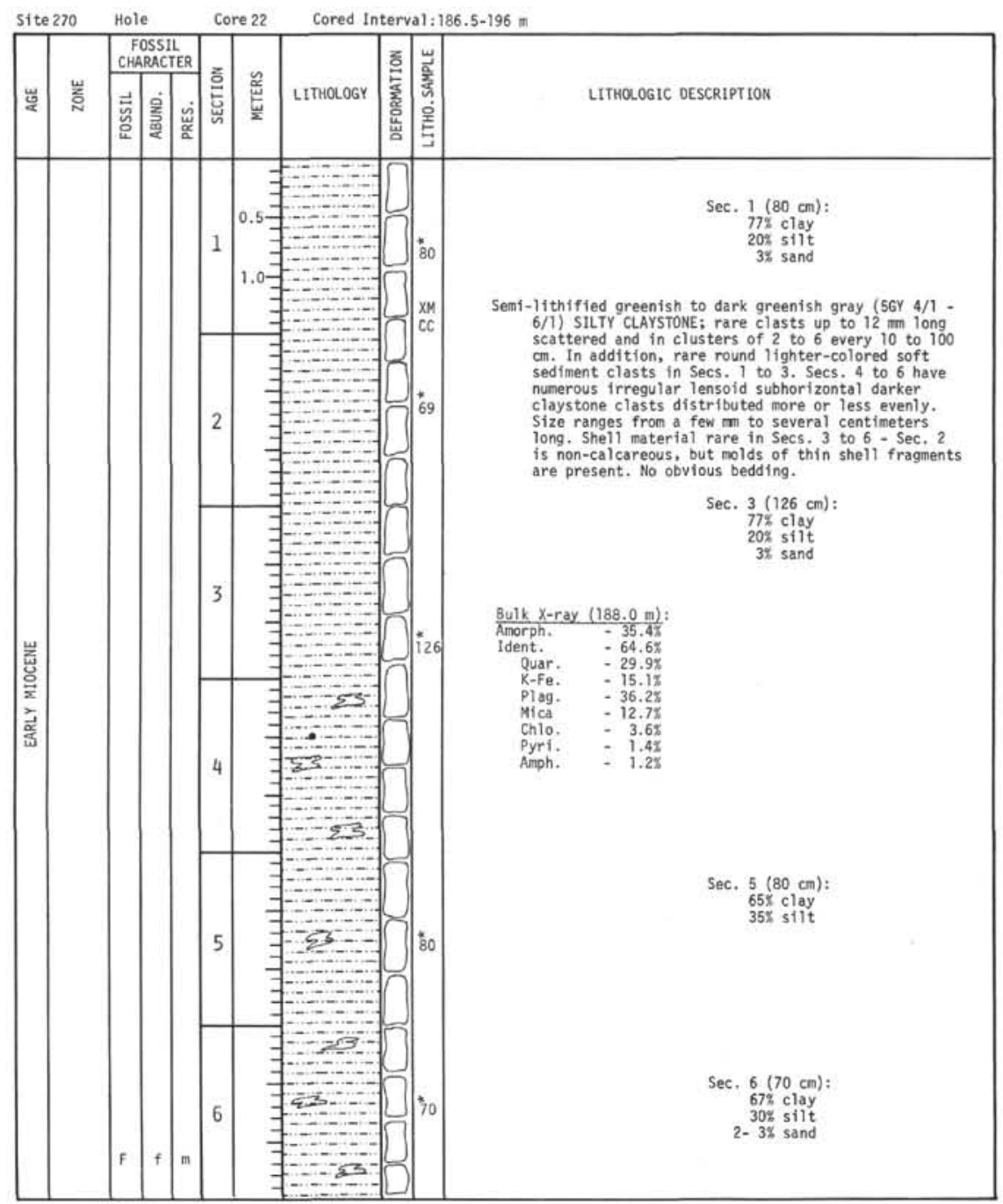

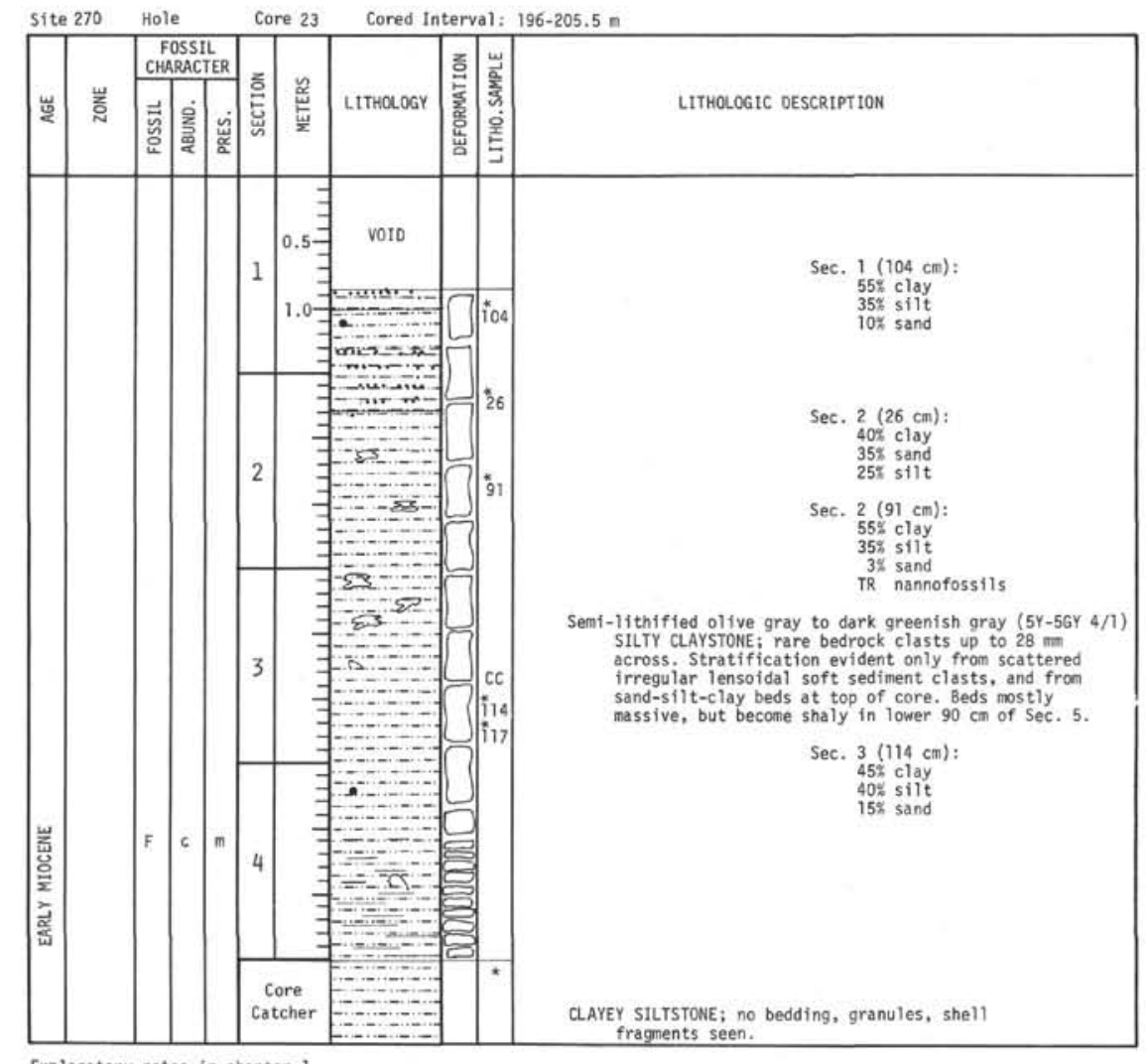




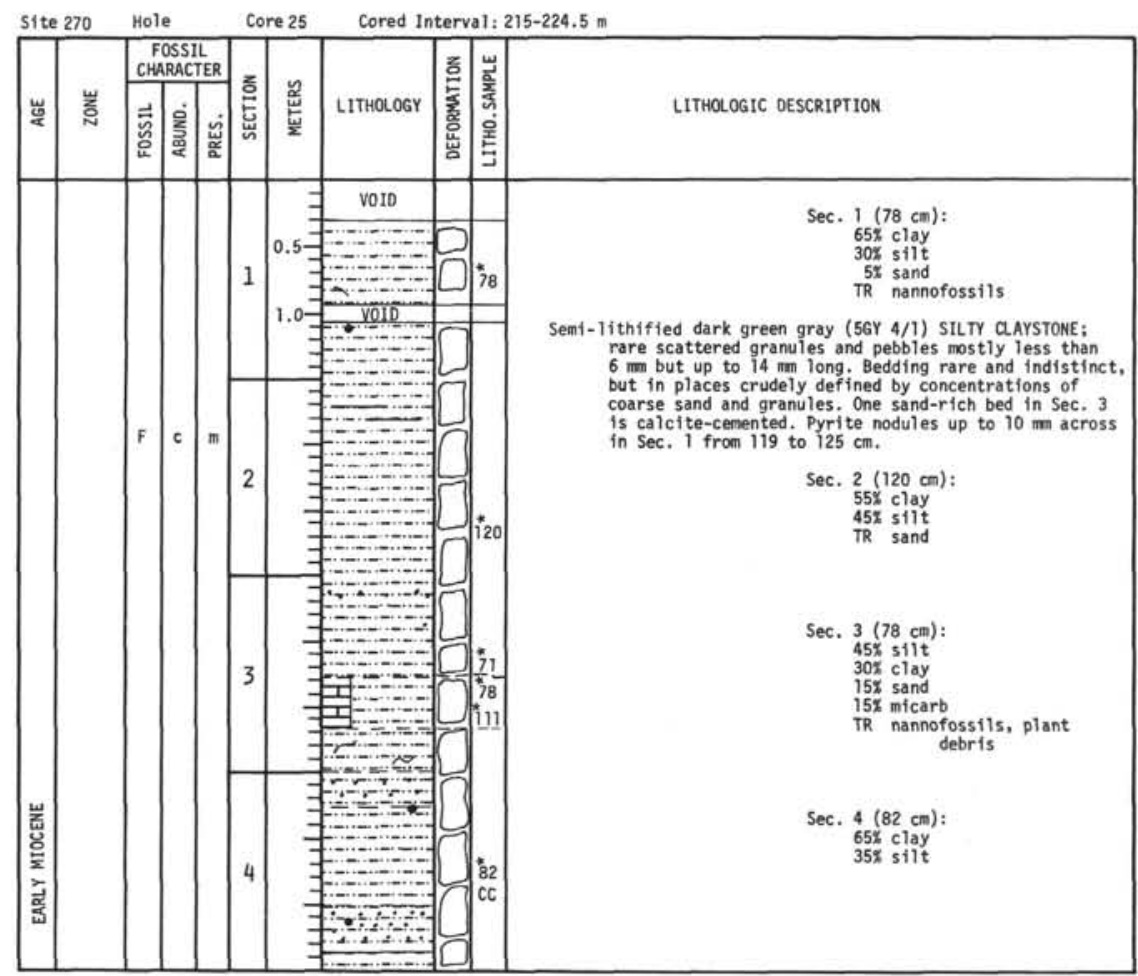



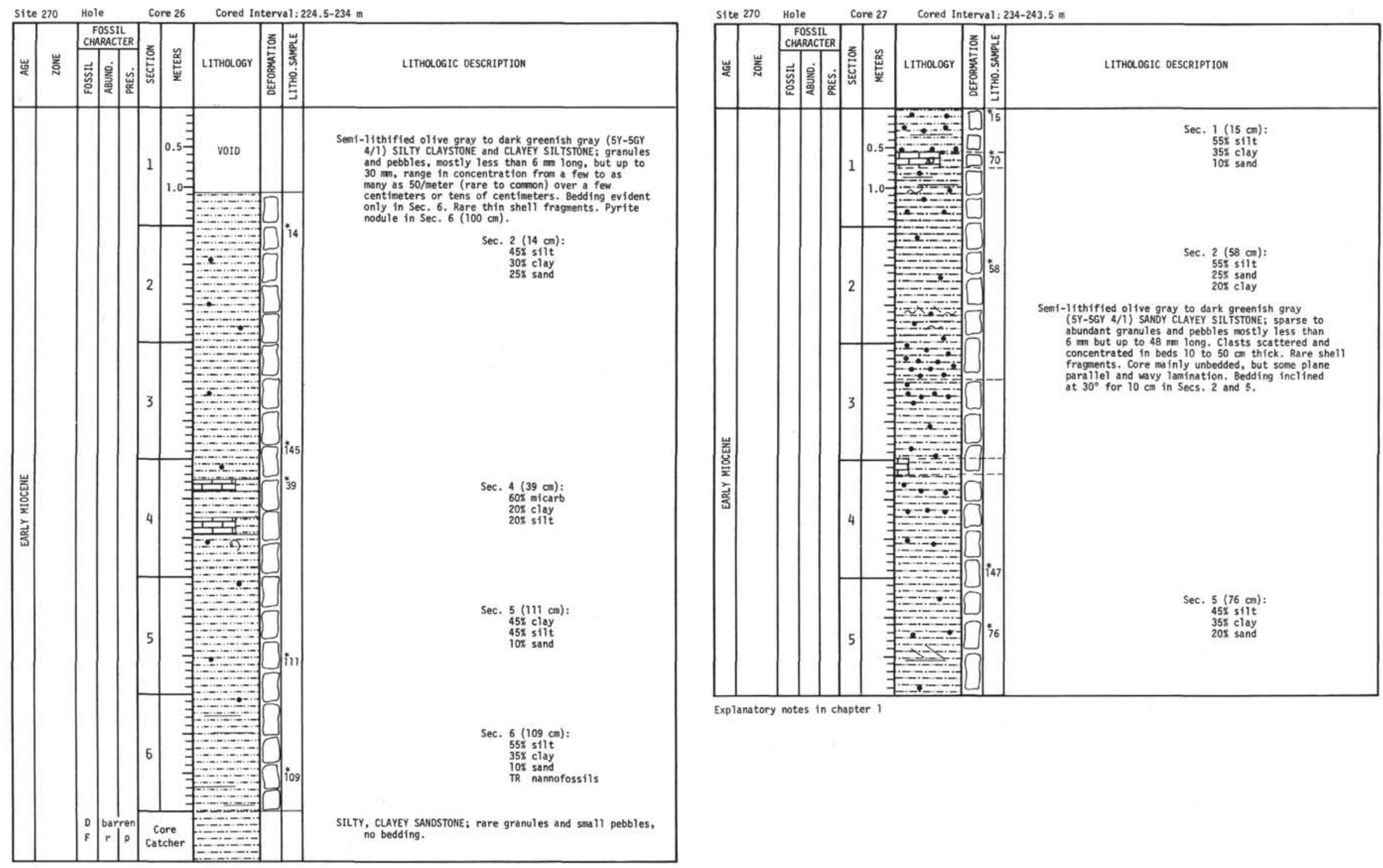

Explanatory notes in chapter 1 


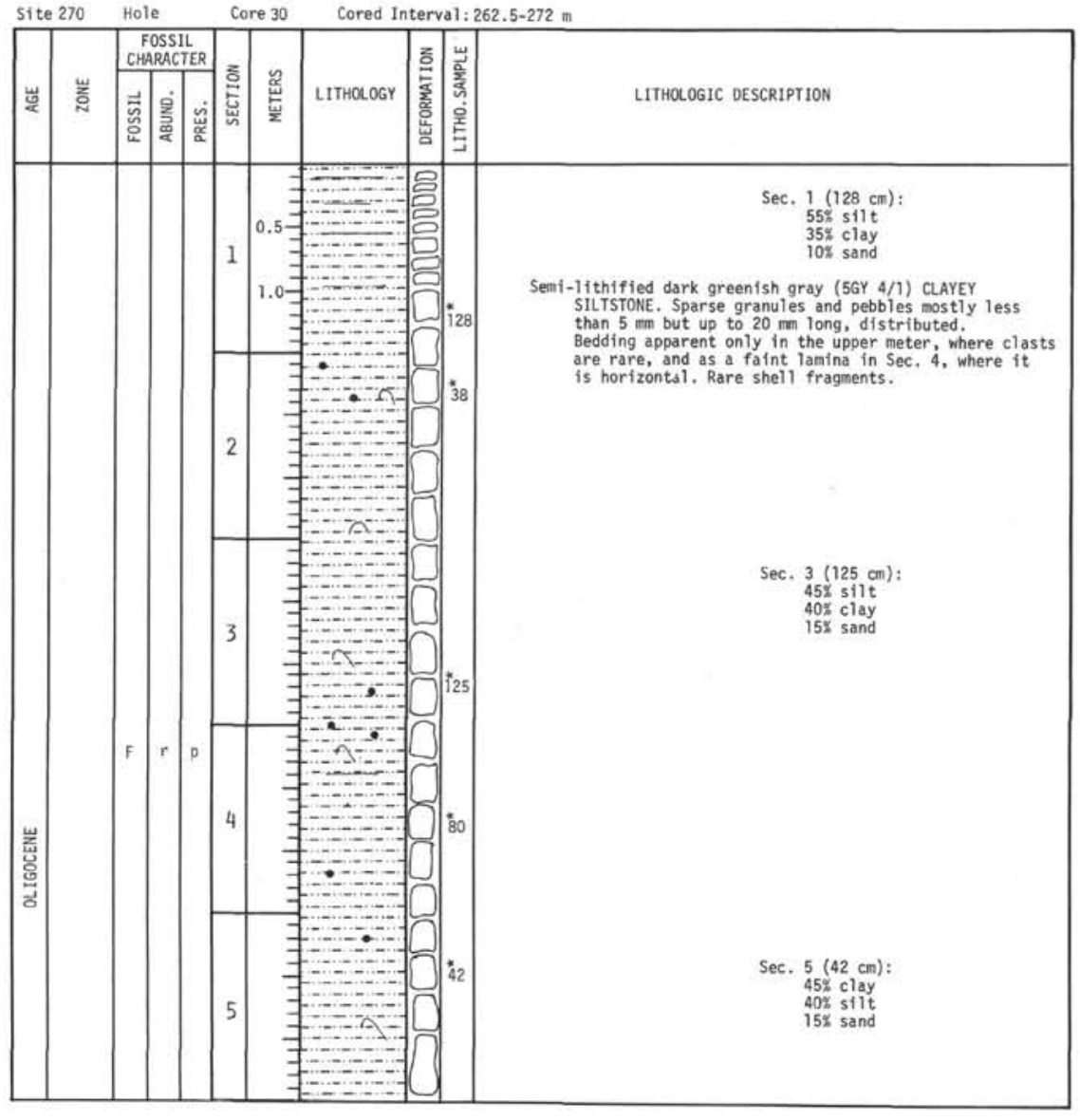

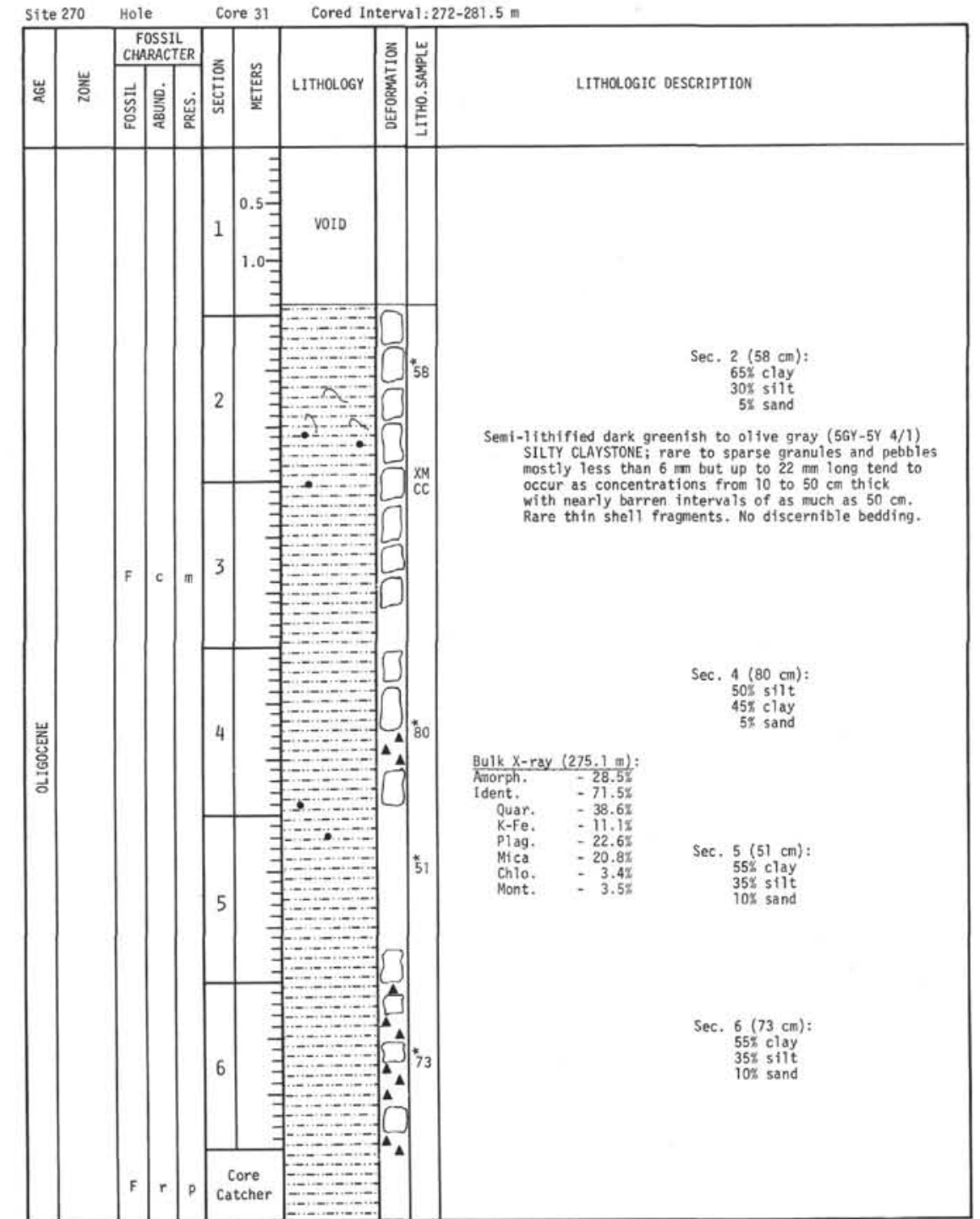

Explanatory notes in chapter 1 

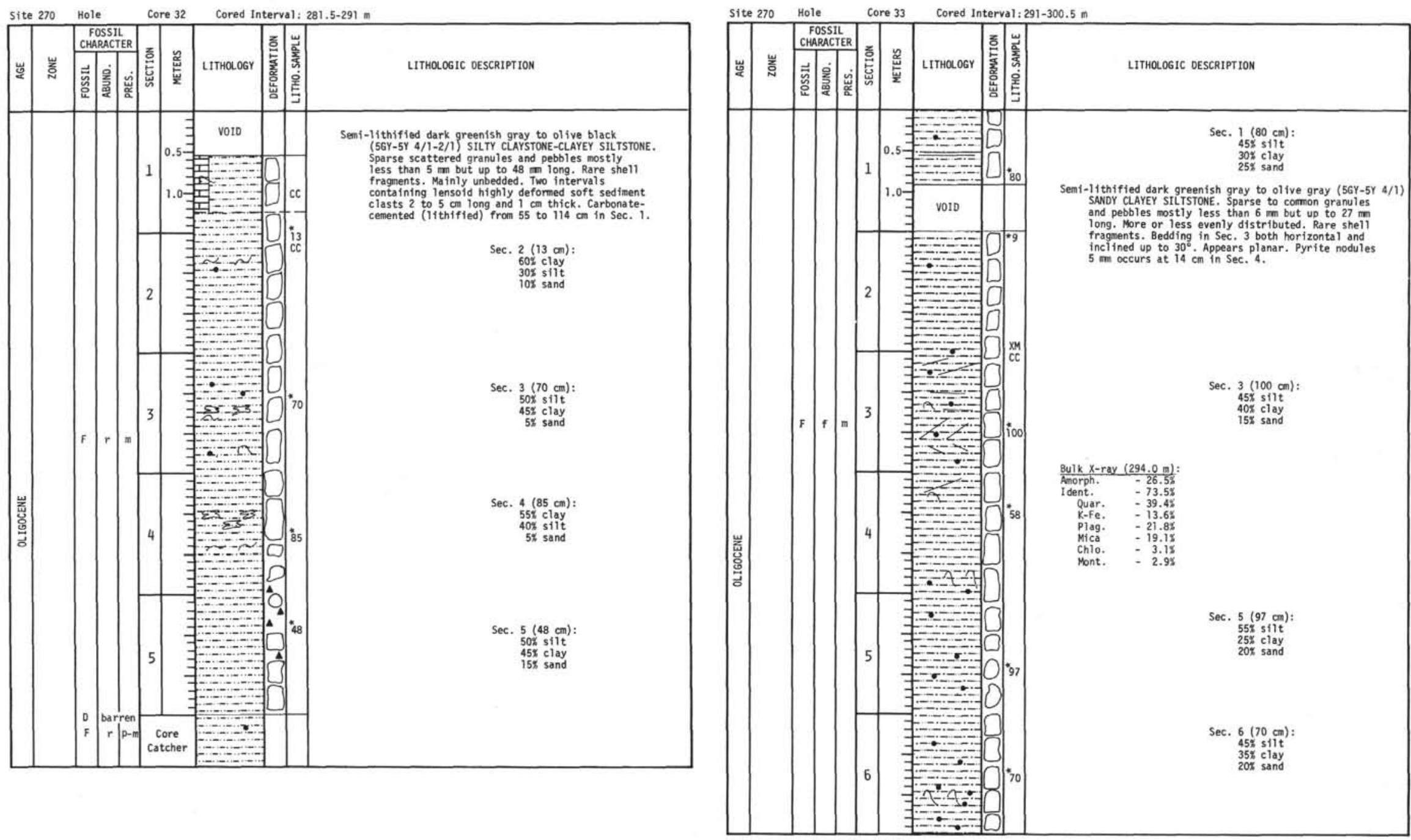

Explanatory notes in Chapter 1 


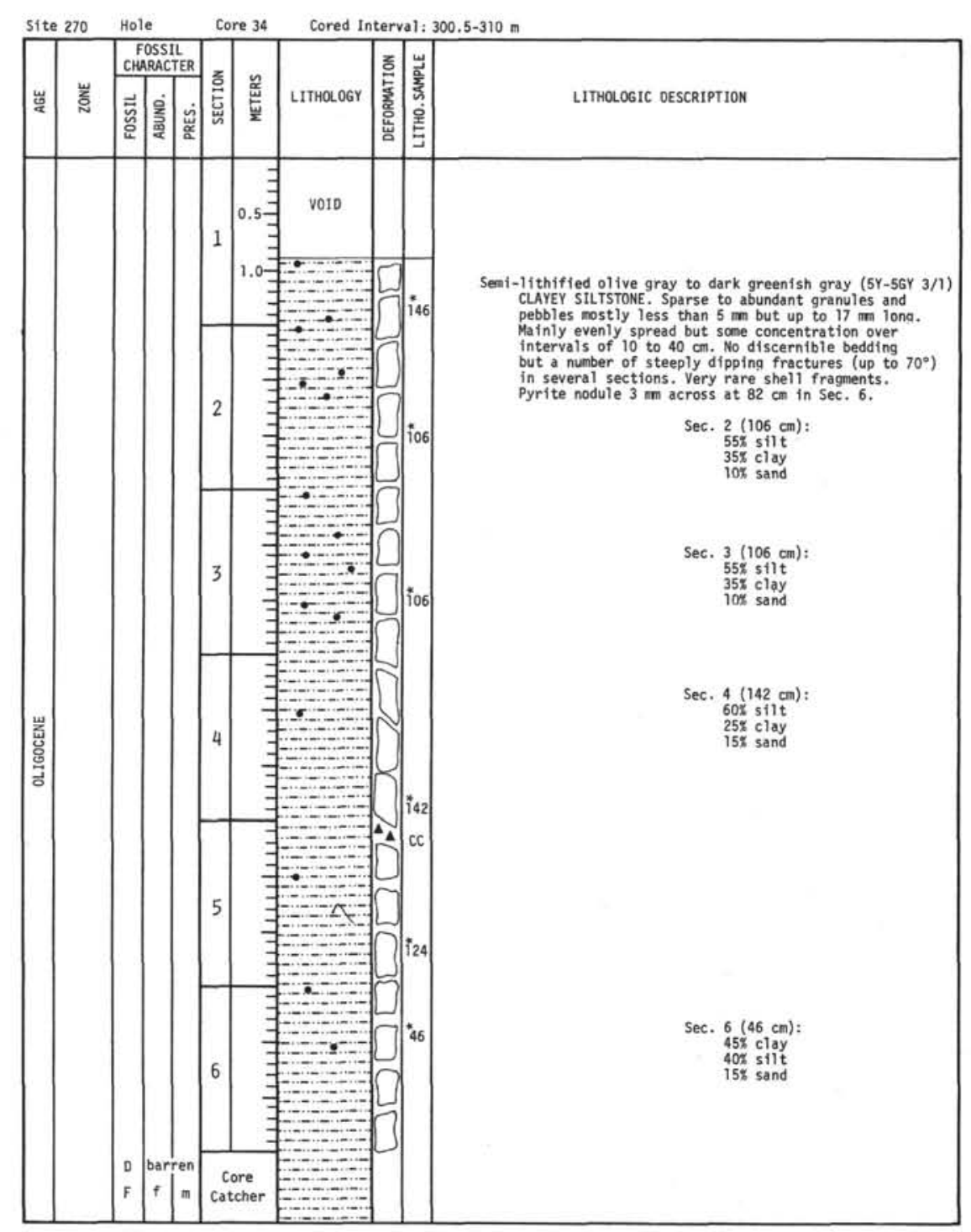

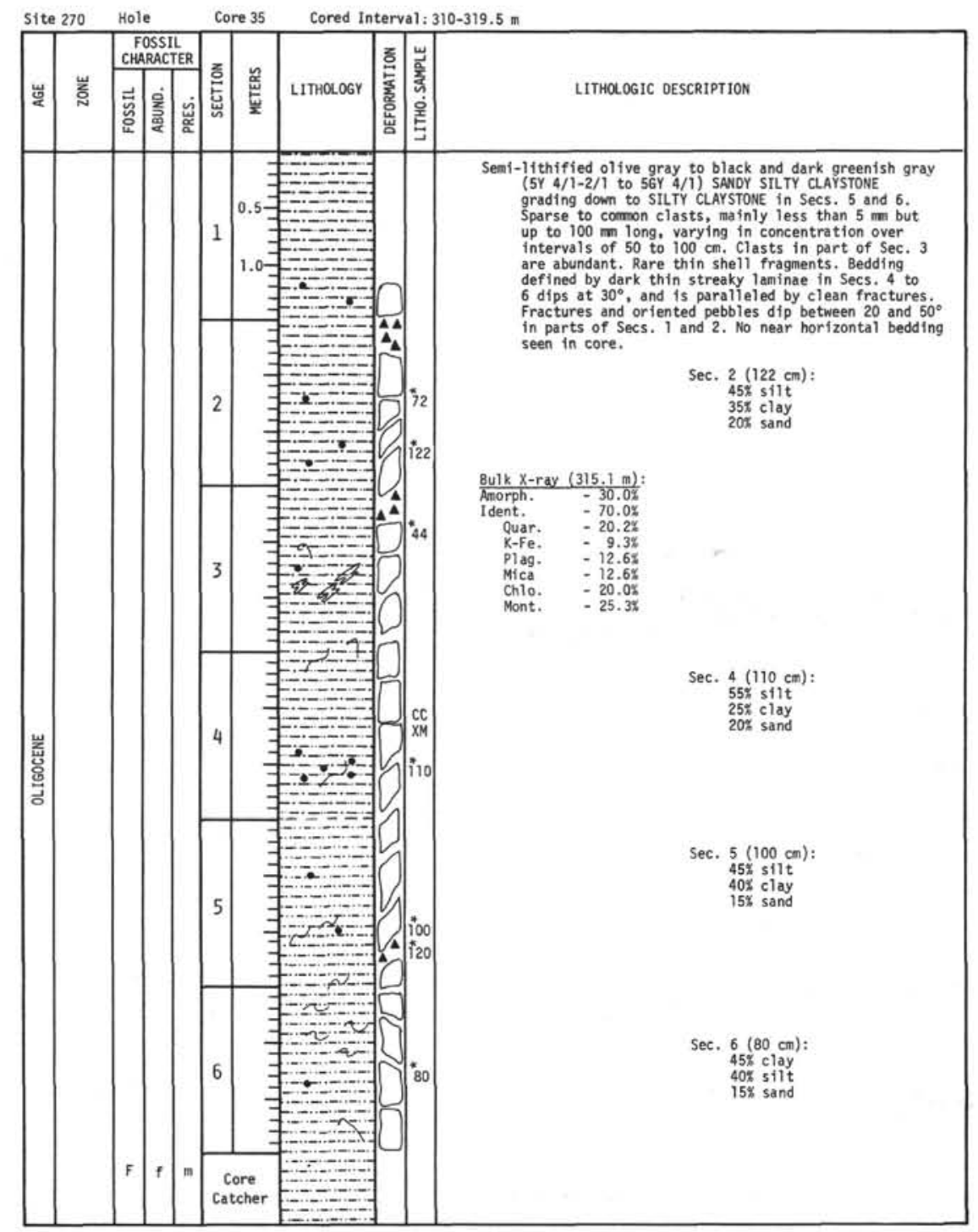

Explanatory notes in Chapter 1 


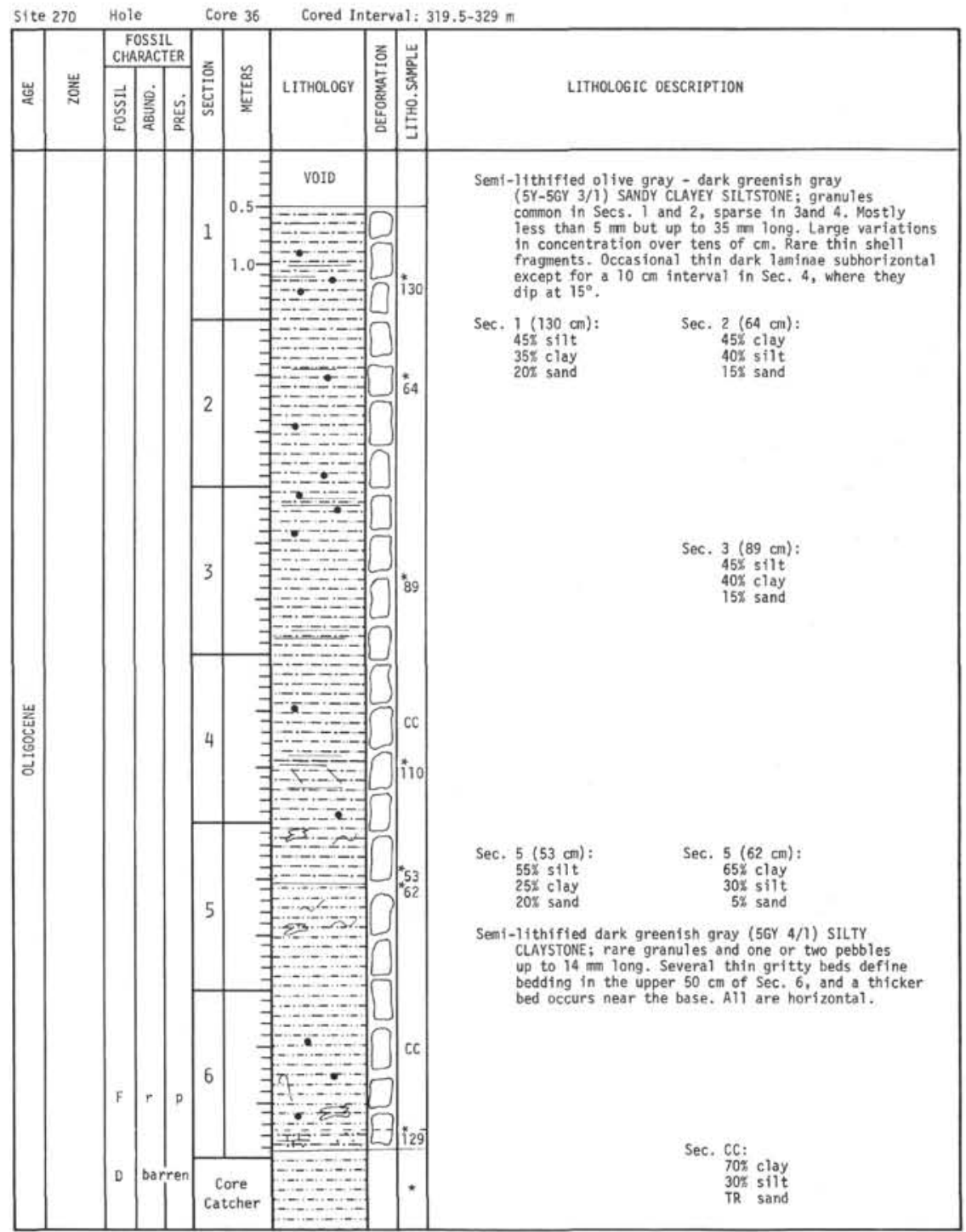

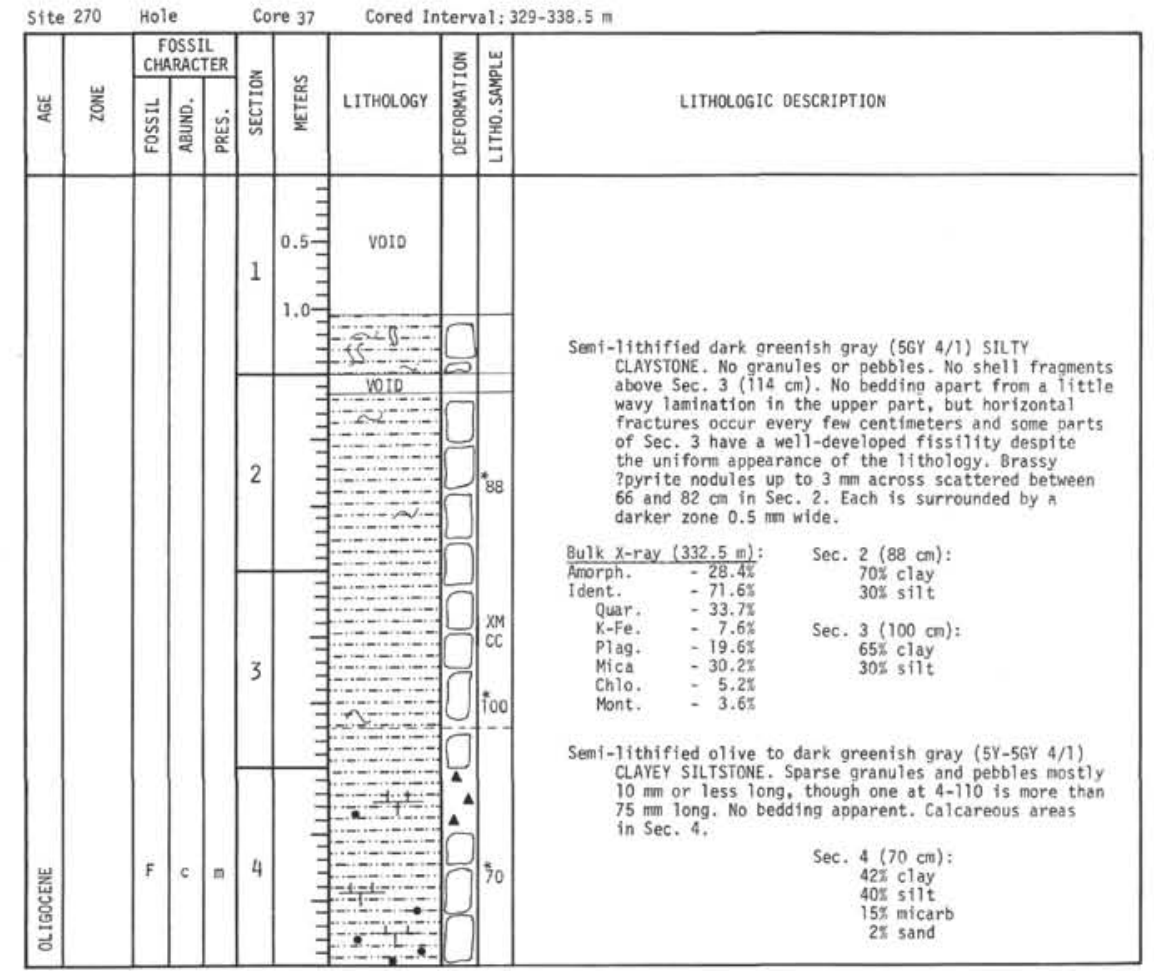

Explanatory notes in Chapter 1 

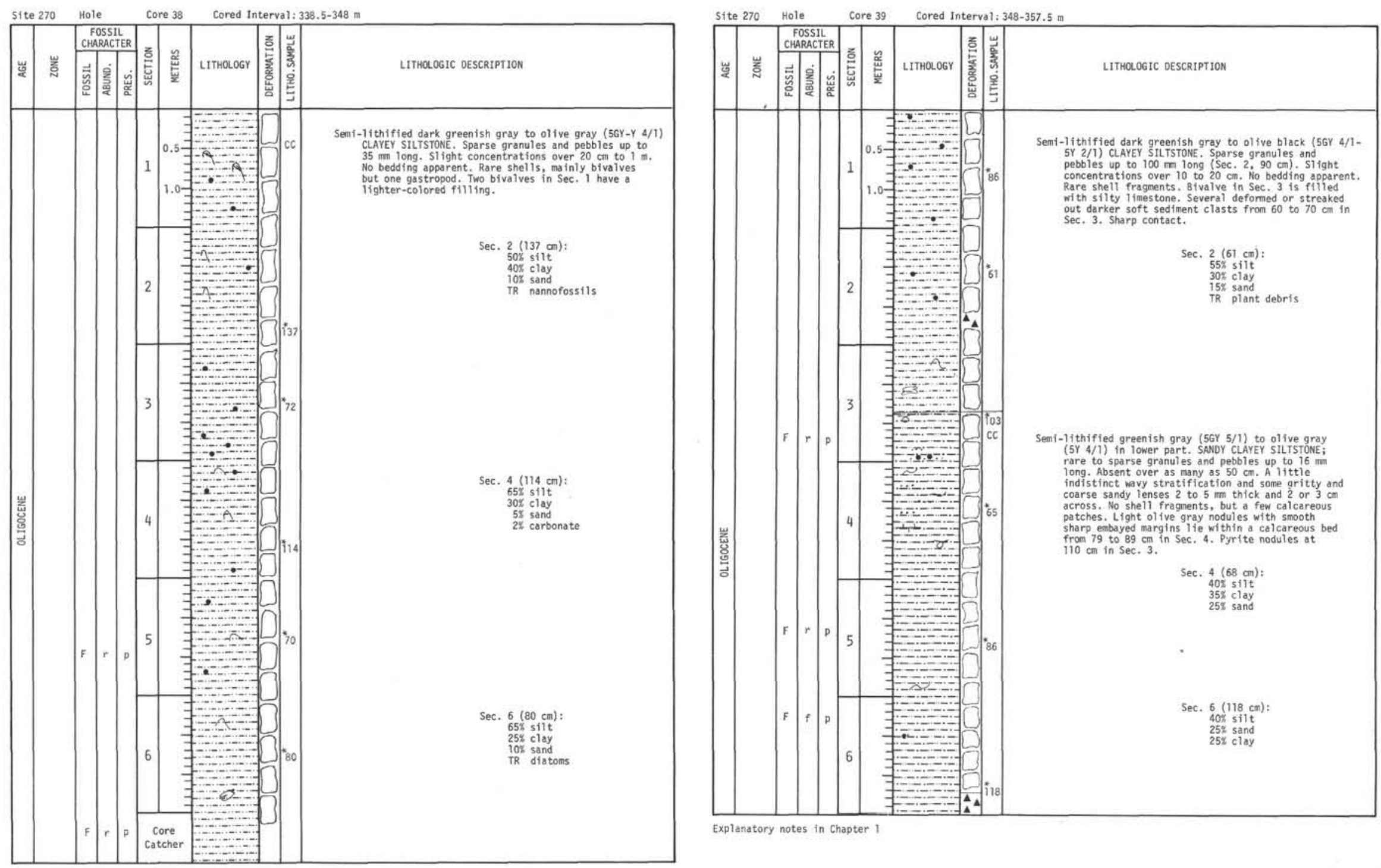


\begin{tabular}{|c|c|c|c|c|c|c|c|c|c|}
\hline itte & & Hole & & & 840 & & & & \\
\hline 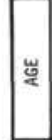 & 亏ัّ & & 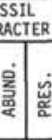 & 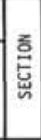 & 离 & LITHOOOGY & 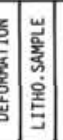 & ᄂтнО.:061 & ESCRPPTION \\
\hline & & $F$ & & 2 & & Po10 & $=f^{60}$ & 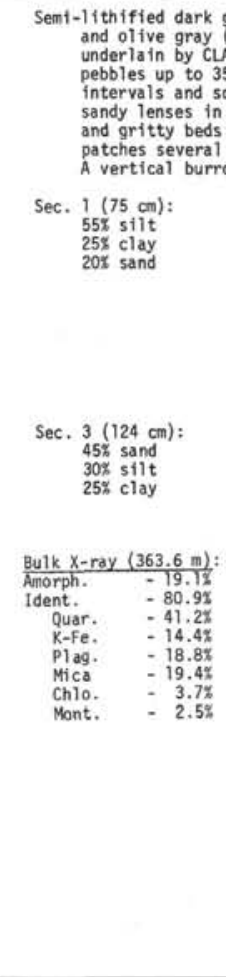 & 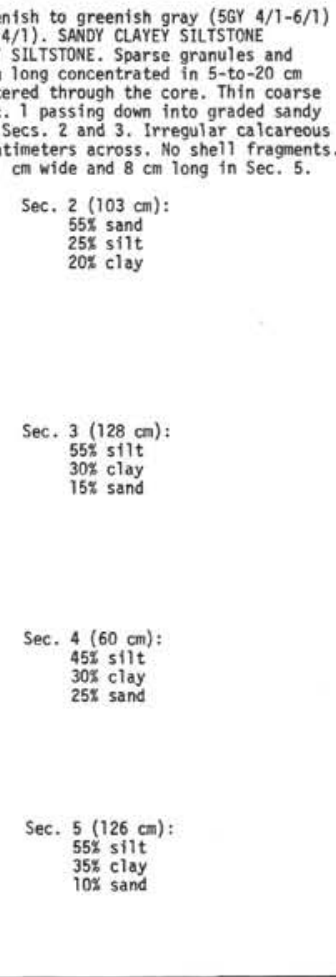 \\
\hline
\end{tabular}

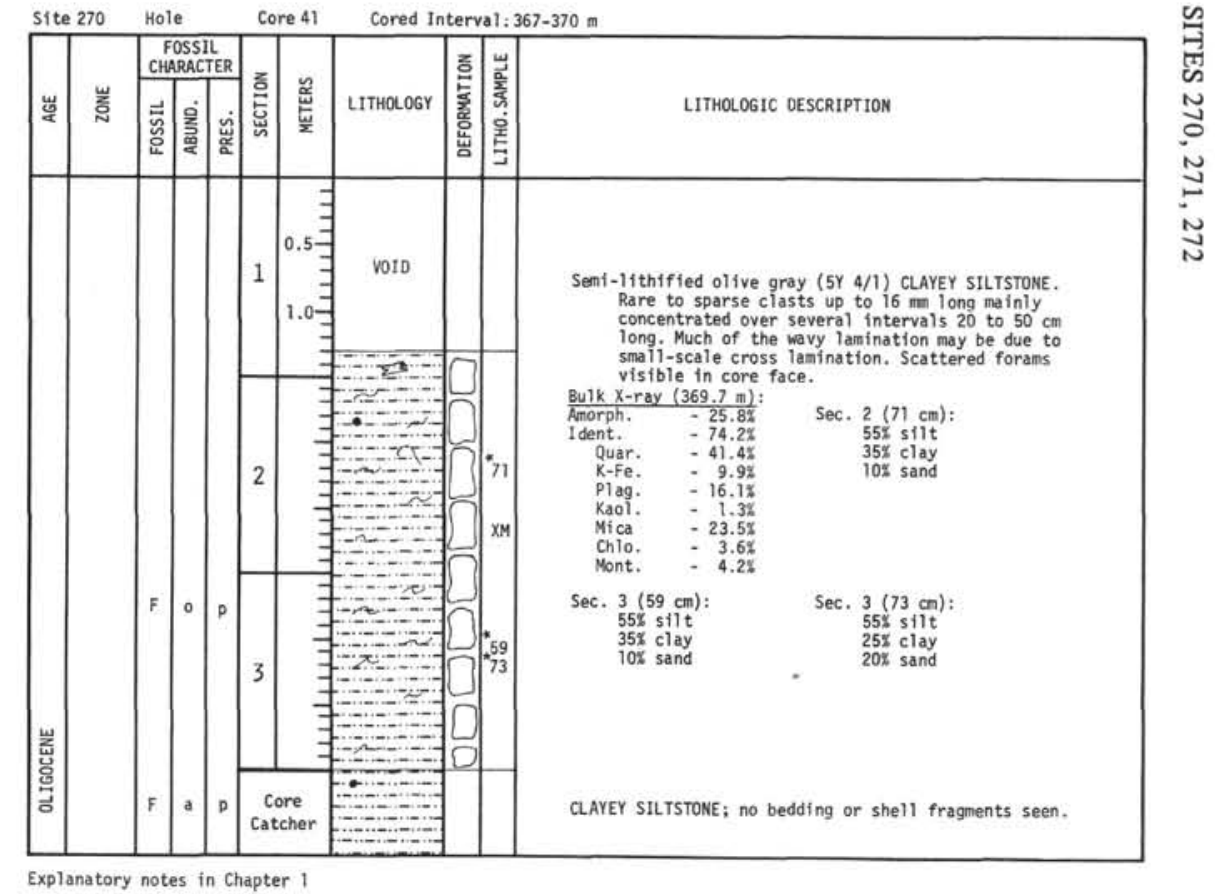




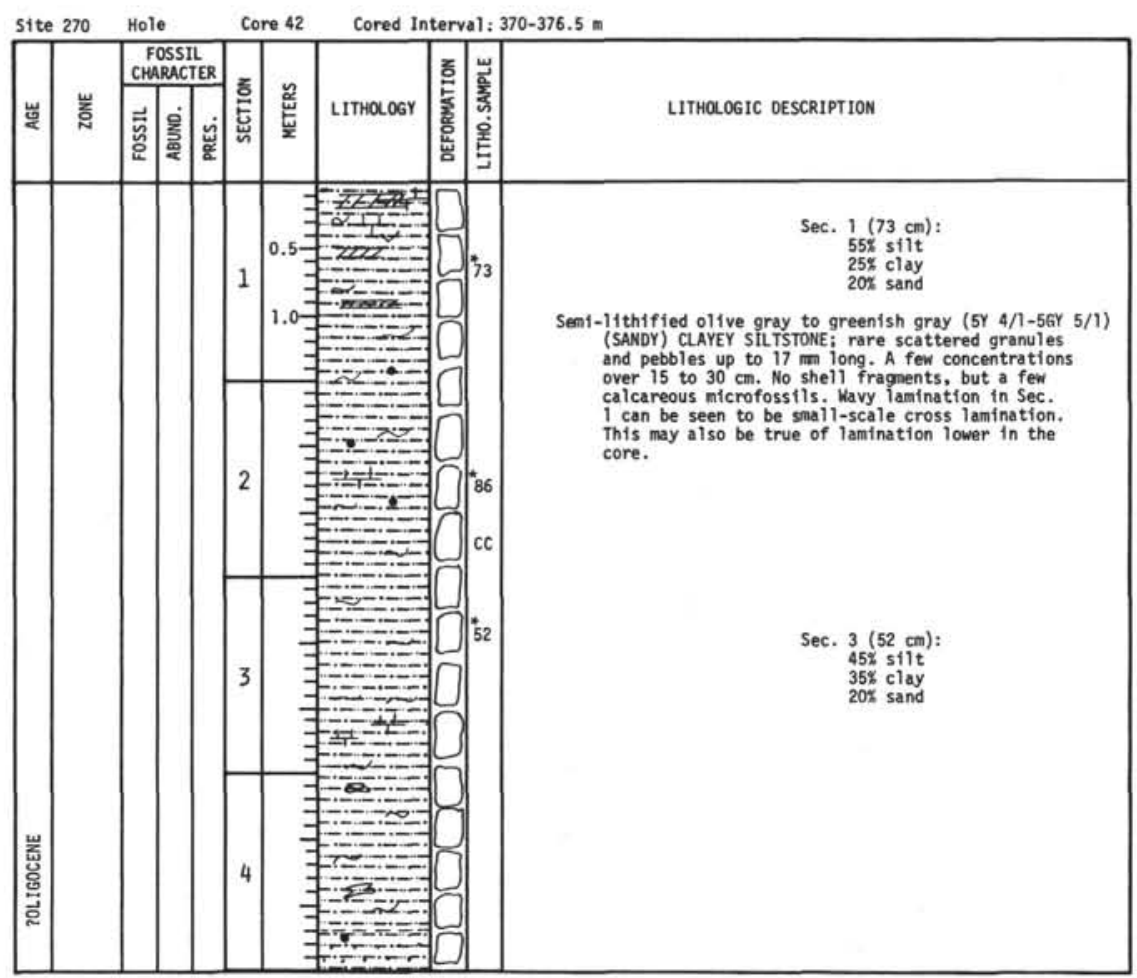

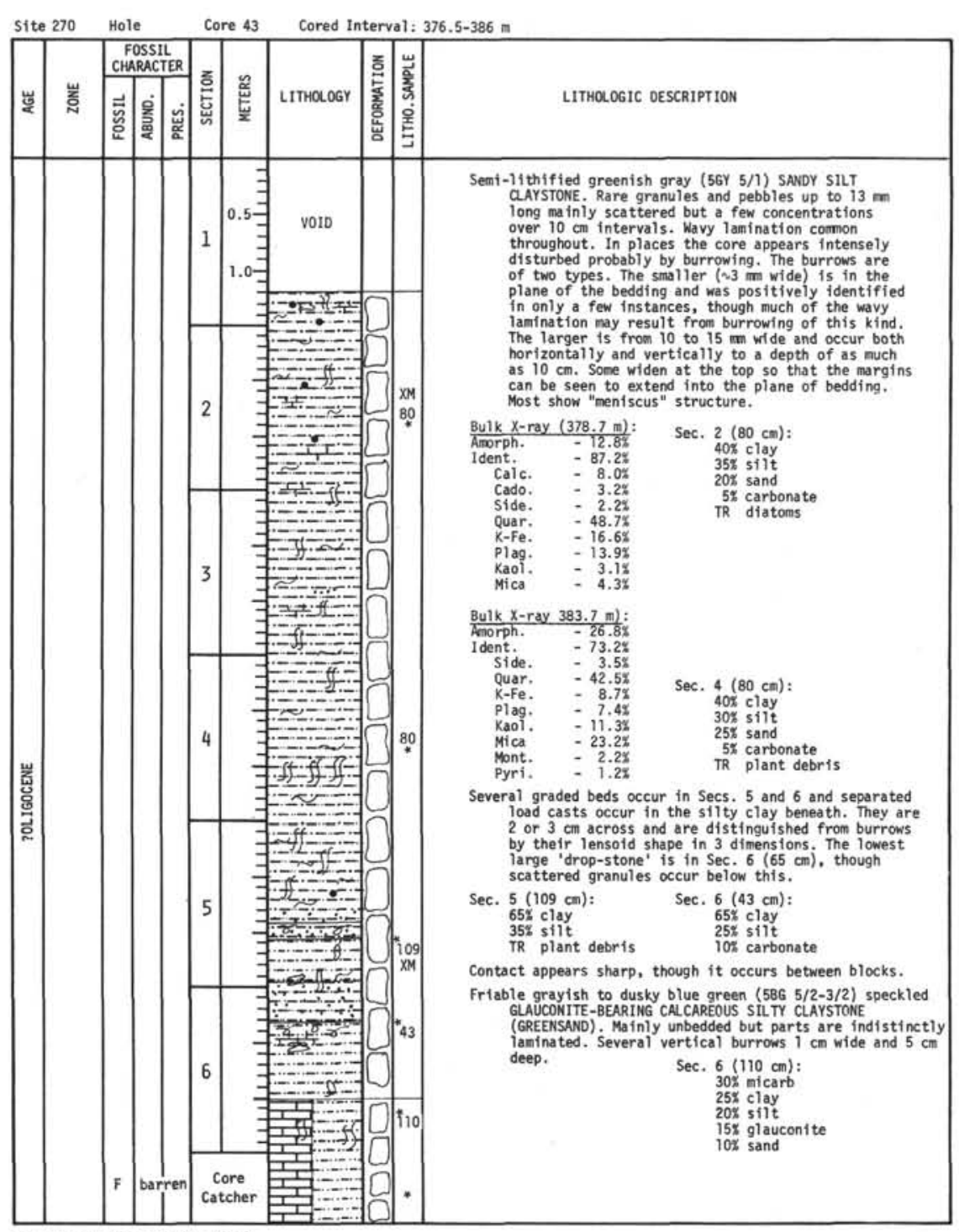

Explana tory notes in chapter 


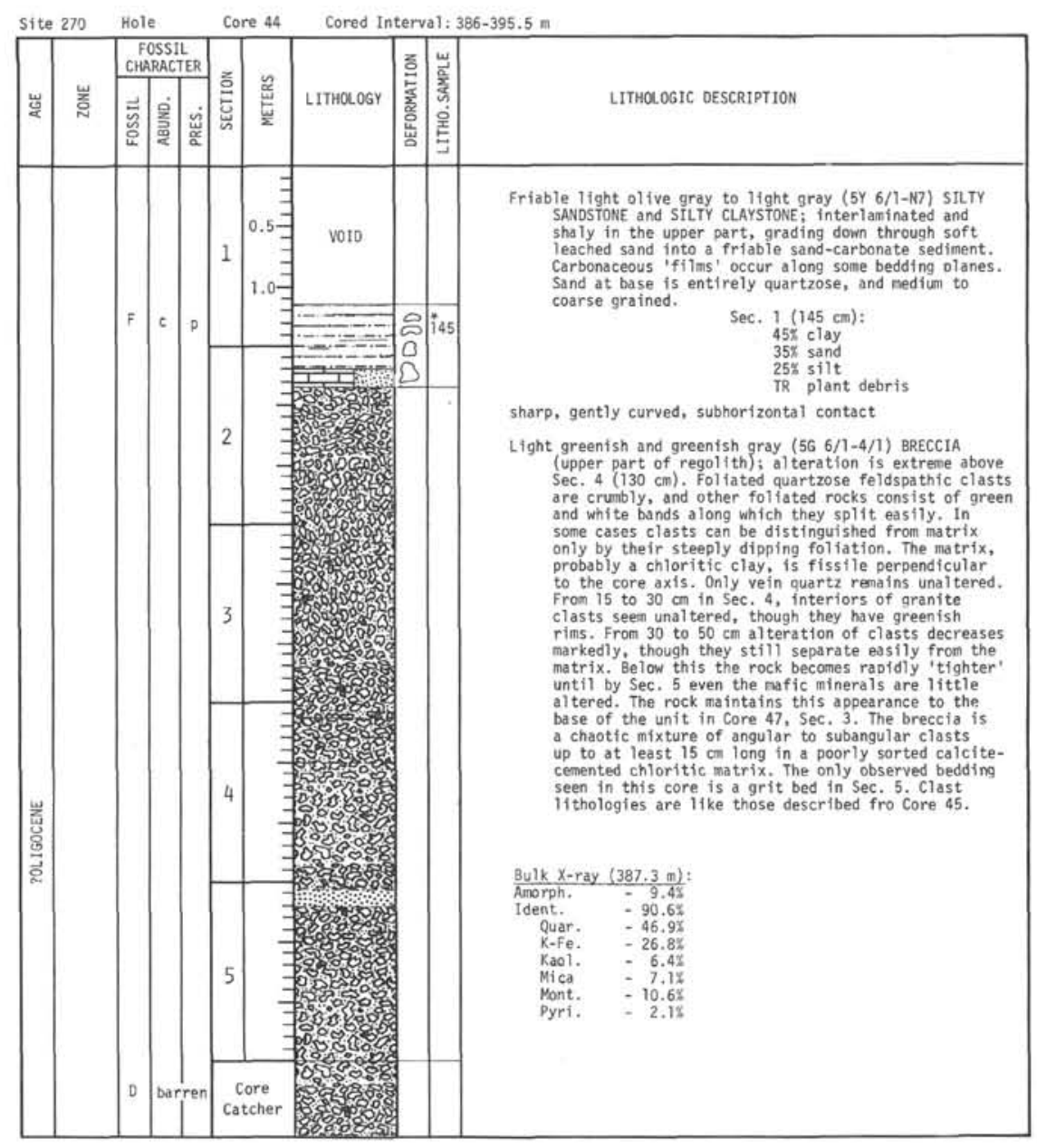

\begin{tabular}{|c|c|c|c|c|c|c|c|}
\hline 岁 & 容 & 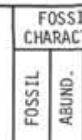 & (CTRR & 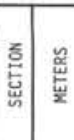 & LITHOLOGY & 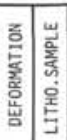 & LITHOLOGIC OESCRIPTION \\
\hline & & & . & \begin{tabular}{|l|l|} 
& \\
& \\
& \\
$\begin{array}{c}\text { Core } \\
\text { catcher }\end{array}$
\end{tabular} & 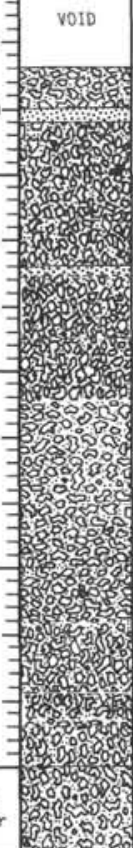 & & 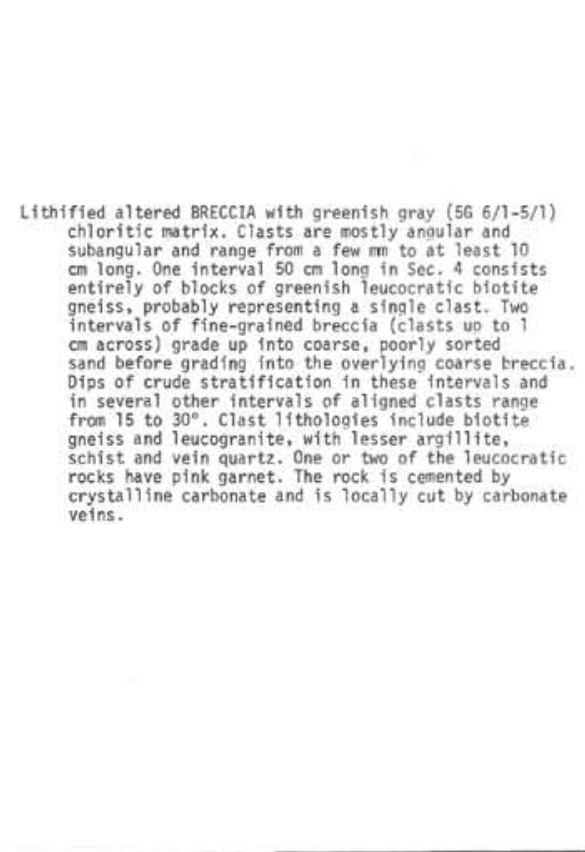 \\
\hline
\end{tabular}



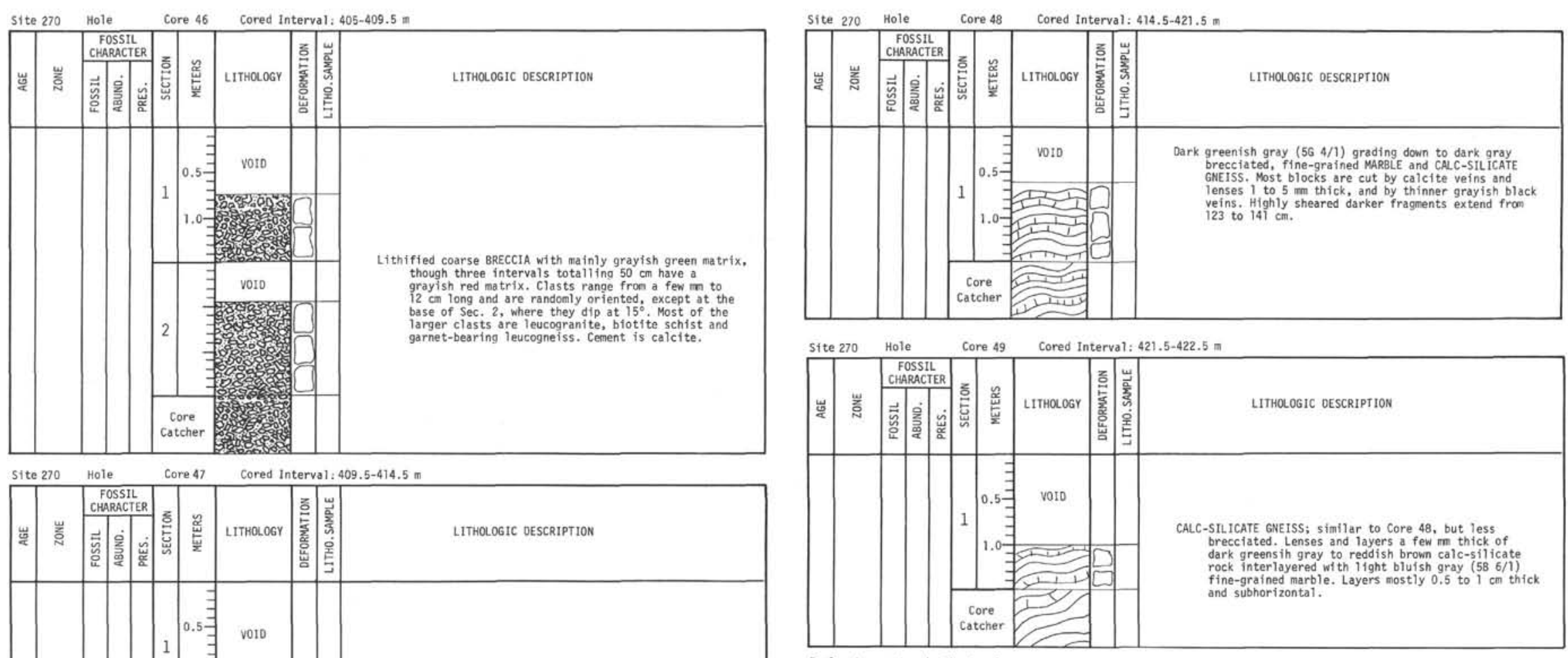

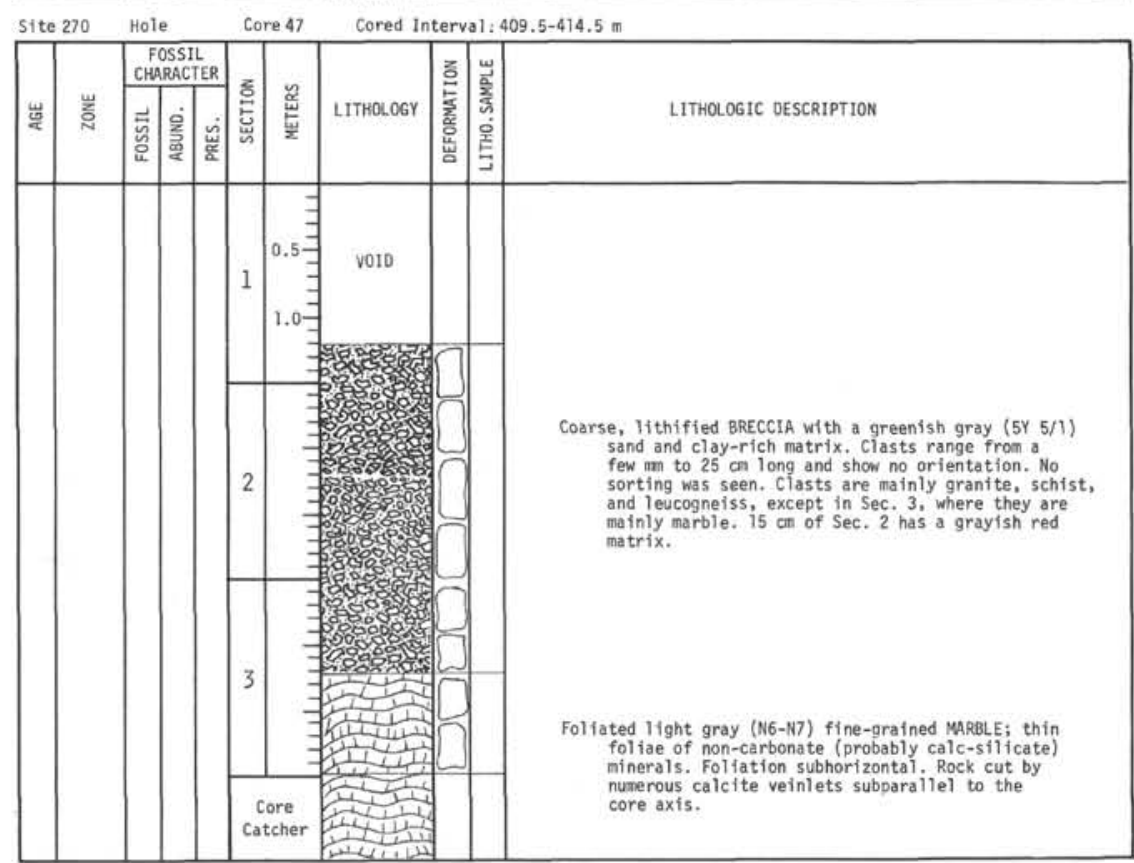

Explanatory notes in Chapter 1 

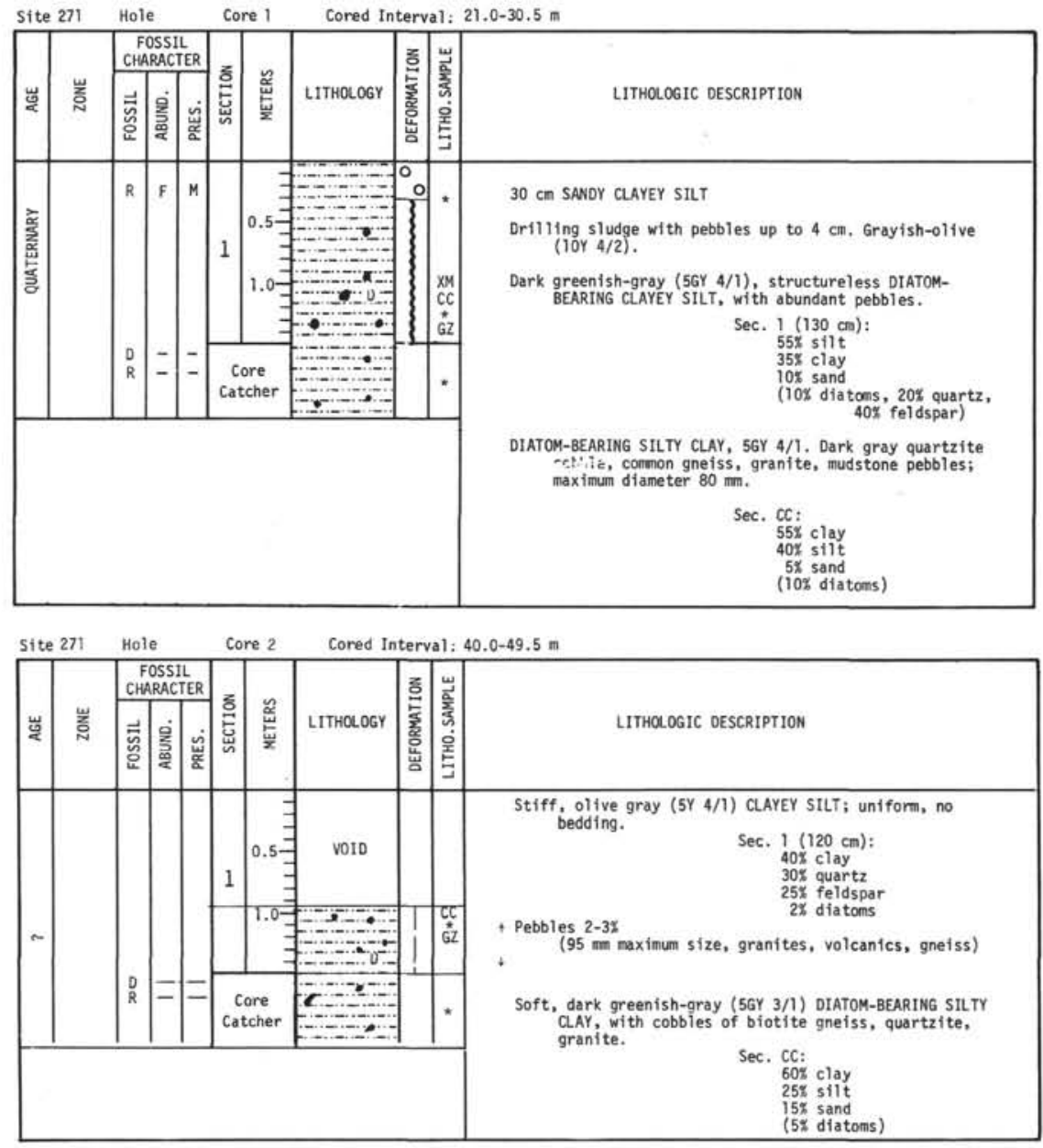
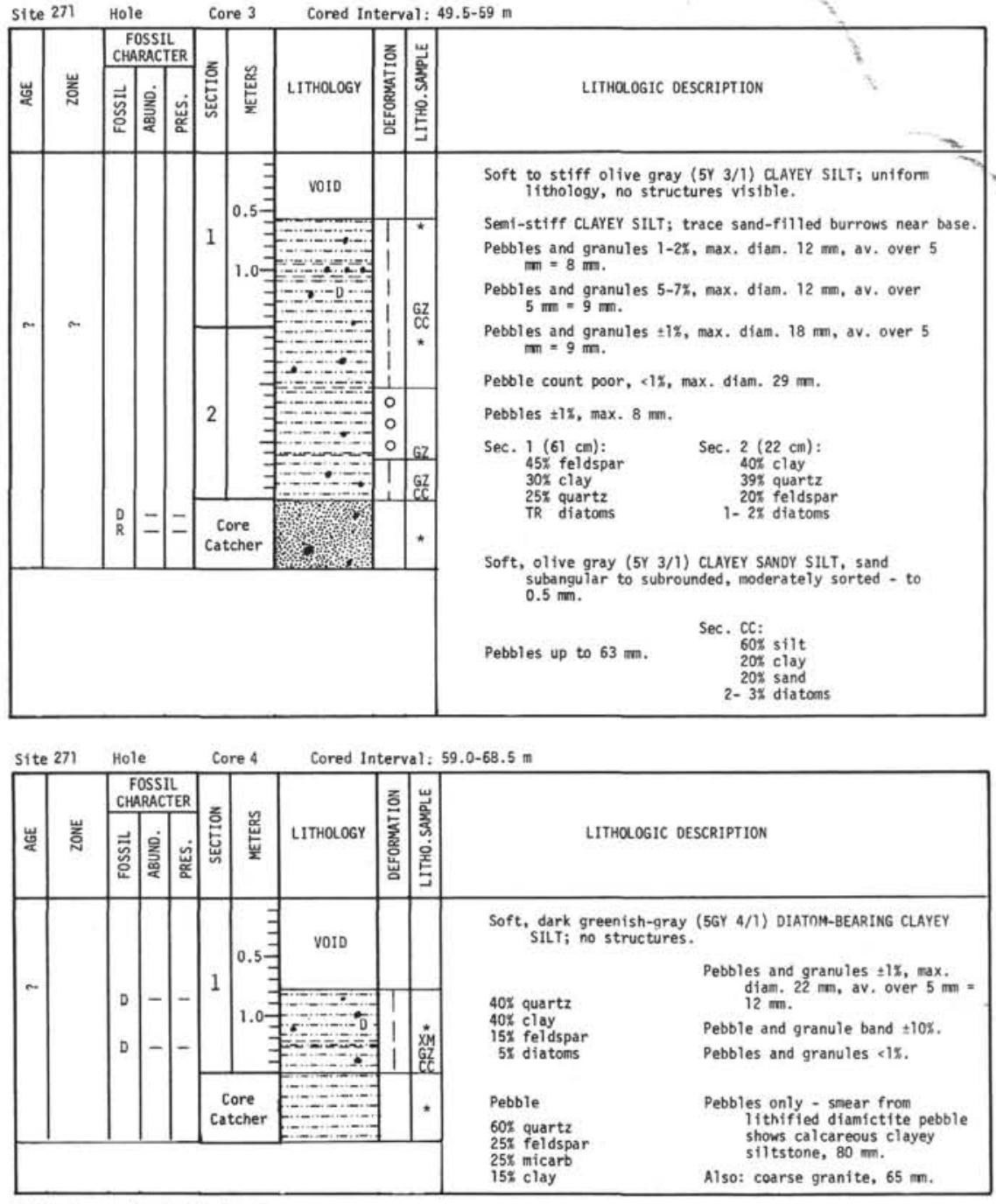

Explanatory notes in Chapter 1 


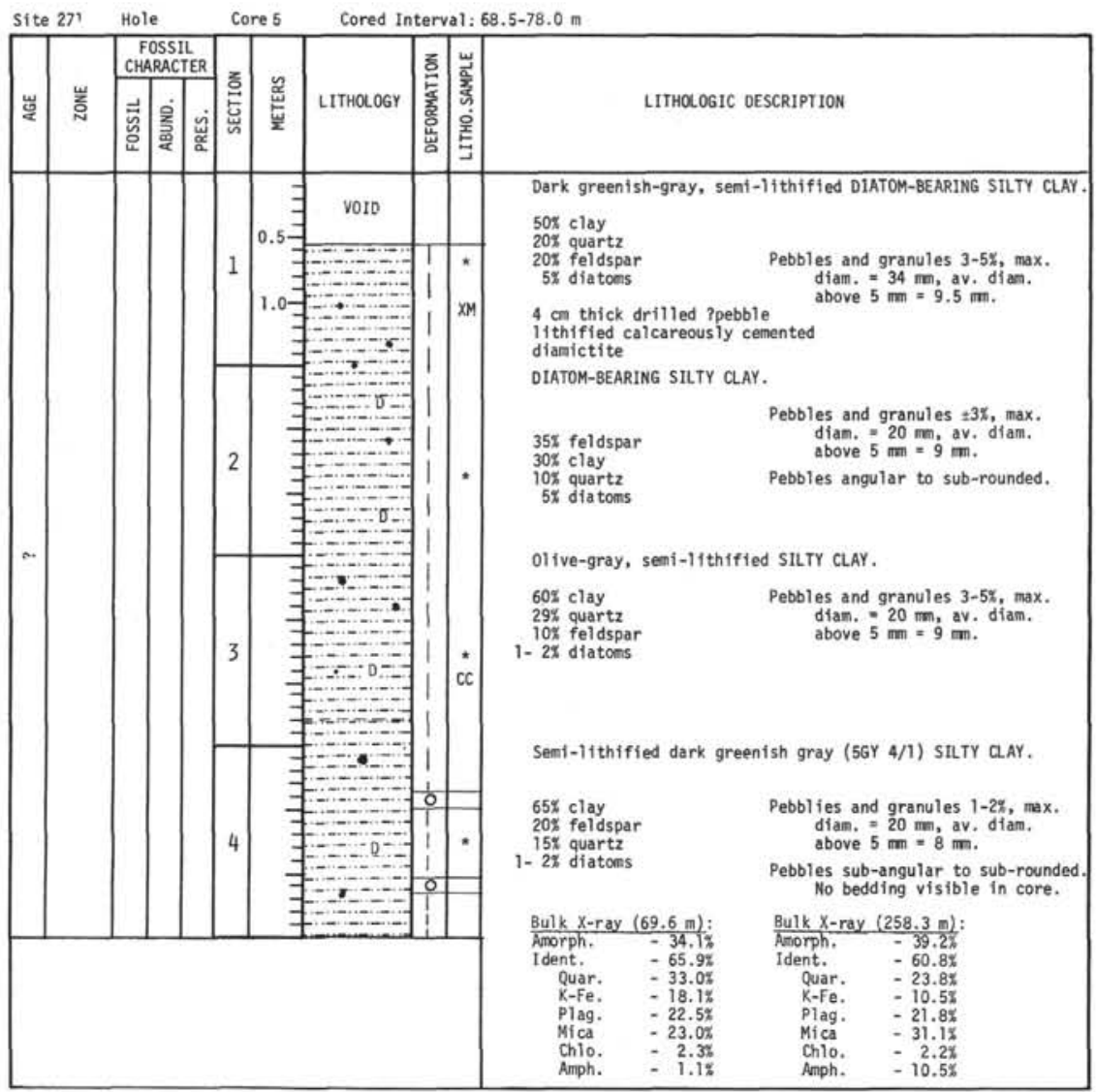

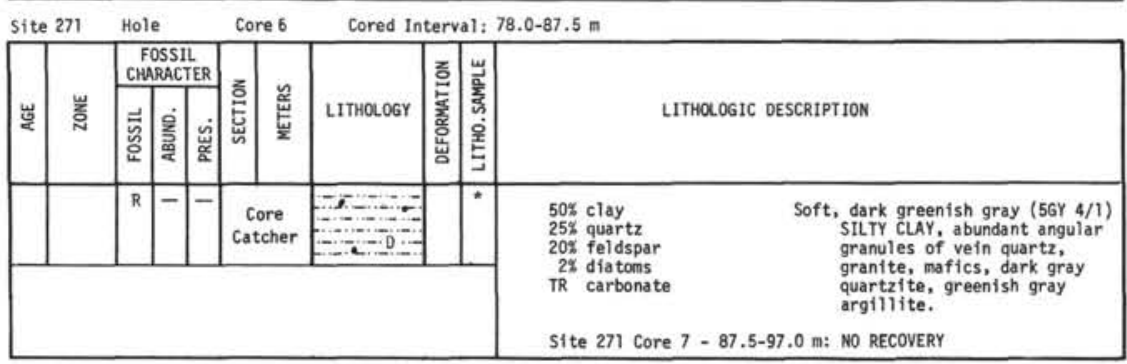

\begin{tabular}{|c|c|c|c|c|c|c|c|c|}
\hline \multicolumn{2}{|c|}{ Site 271 } & Hole & \multicolumn{2}{|c|}{ core 8} & \multicolumn{3}{|c|}{ Cored Interval; $97.0-106.5 \mathrm{~m}$} & \\
\hline & & 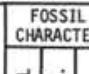 & & & & & & \\
\hline 莛 & 容 & 氮这 & 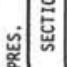 & 登 & LITHOLOGY & 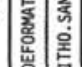 & LIтнос & SCRIPTION \\
\hline & & & & $\begin{array}{l}\text { Core } \\
\text { tcher }\end{array}$ & & & 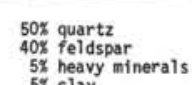 & $\begin{array}{l}\text { Concentrate of coarse sand } \\
\text { anshed from core catcher } \\
\text { SIlTYY SNWV. }\end{array}$ \\
\hline
\end{tabular}

\begin{tabular}{|c|c|c|c|c|c|c|c|c|c|}
\hline \multicolumn{2}{|c|}{ Site 271} & \multicolumn{2}{|c|}{ Hole } & \multicolumn{2}{|c|}{ Core 9} & \multicolumn{3}{|c|}{ Cored Interval: $106.5-116.0 \mathrm{~m}$} & \\
\hline \multirow[b]{2}{*}{ 崖 } & \multirow[b]{2}{*}{ 訔 } & \multicolumn{2}{|c|}{\begin{tabular}{|c|} 
FOSSIL \\
CHARACIER \\
\end{tabular}} & \multirow[b]{2}{*}{ 总 } & \multirow[b]{2}{*}{ 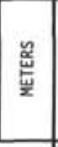 } & \multirow[b]{2}{*}{ LITHOLOGY } & \multirow[b]{2}{*}{ 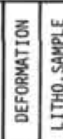 } & \multirow{2}{*}{\multicolumn{2}{|c|}{ LITHOLOGIC OESCRIPTION }} \\
\hline & & 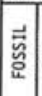 & : & & & & & & \\
\hline \multirow[t]{2}{*}{$\sim$} & & $\mathrm{R}$ & $-1-$ & & $\begin{array}{l}\text { iore } \\
\text { tcher }\end{array}$ & 8 & * & \multirow{2}{*}{ 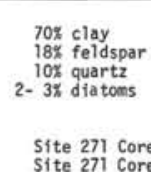 } & $\begin{array}{l}\text { Soft, dark greenish-gray SILTY } \\
\text { CLAY. Granules abundant. }\end{array}$ \\
\hline & & & & & & & & & $\begin{array}{l}\text { Pebble: } 21 \mathrm{~mm} \text {. Medium grained } \\
\text { granite. } \\
-125.5 \mathrm{~m}: \text { NO RECOVERY } \\
-132.0 \mathrm{~m}: \text { NO RECOVERY }\end{array}$ \\
\hline
\end{tabular}

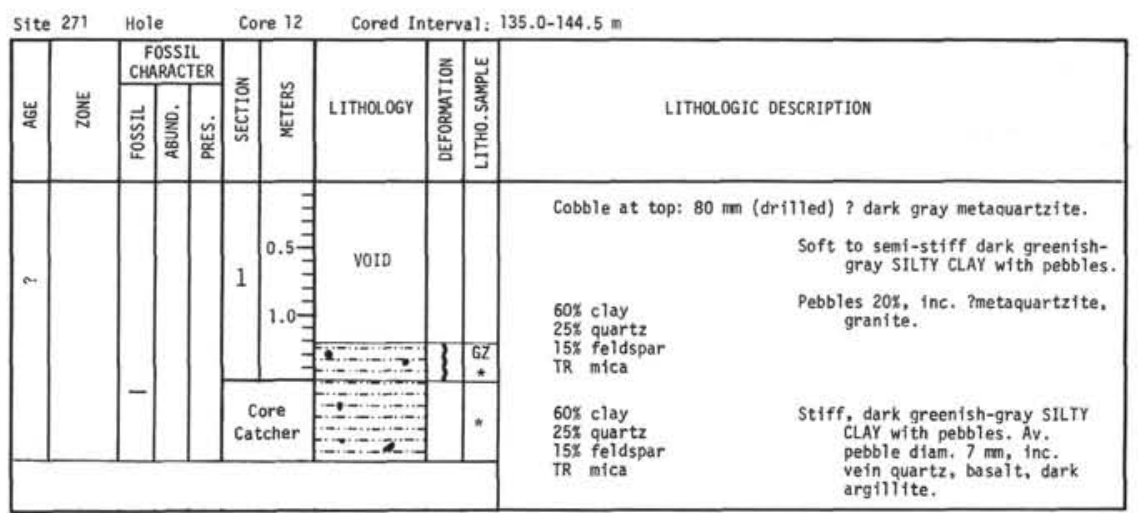

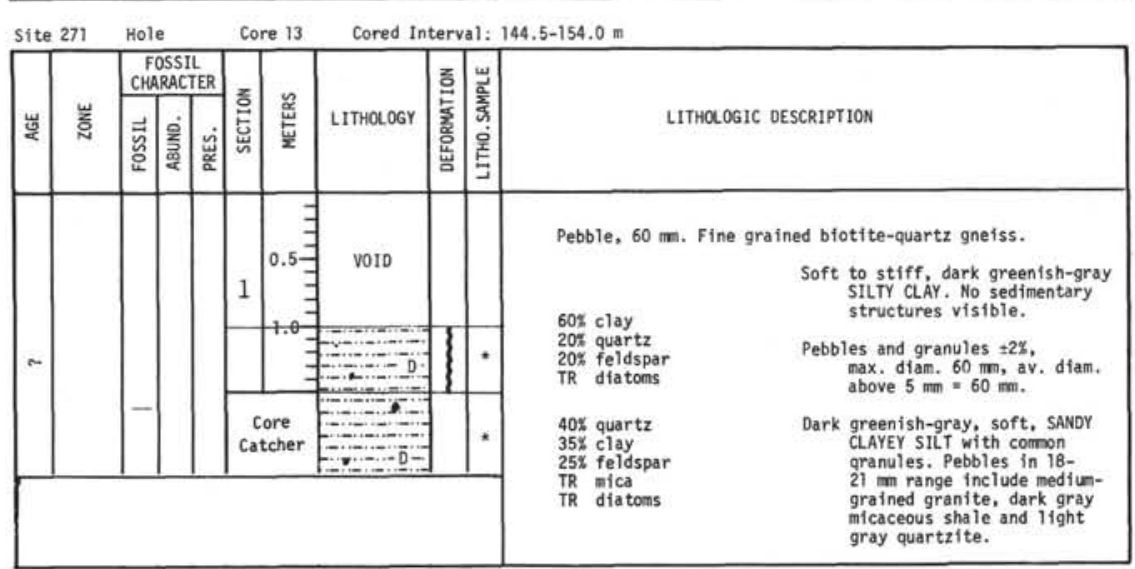

Explanatory notes in Chapter 1 


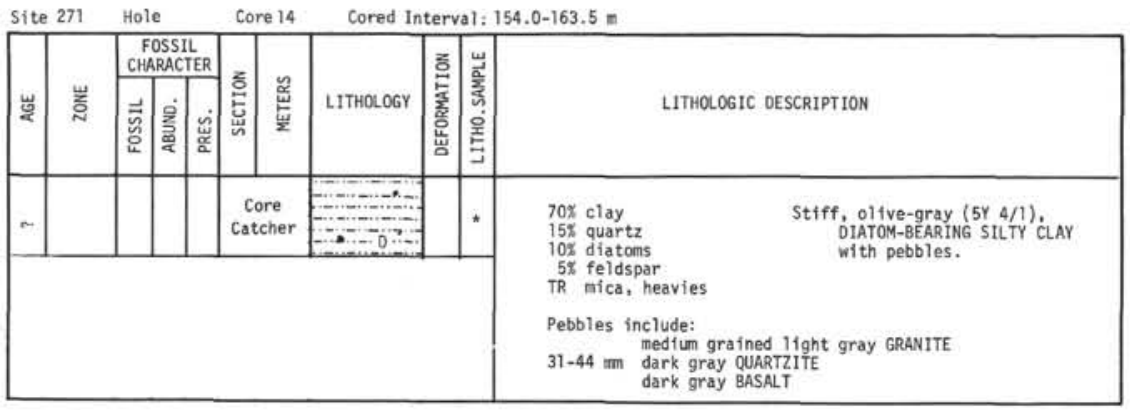

\begin{tabular}{|c|c|c|c|c|c|c|}
\hline ite 2 & & Hole & Core 15 & Cored Int & terval: & $=175.0 \mathrm{~m}$ \\
\hline 宸 & 产 & 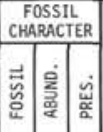 & 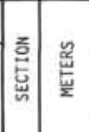 & LITHOLOGY & 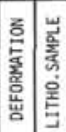 & LITHOLOGIC DESCRIPTION \\
\hline & & & $\begin{array}{c}\text { core } \\
\text { Catcher }\end{array}$ & 08 & & \multirow{2}{*}{ 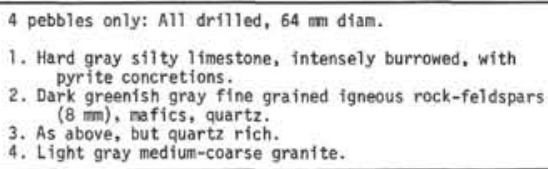 } \\
\hline & & & & & & \\
\hline
\end{tabular}

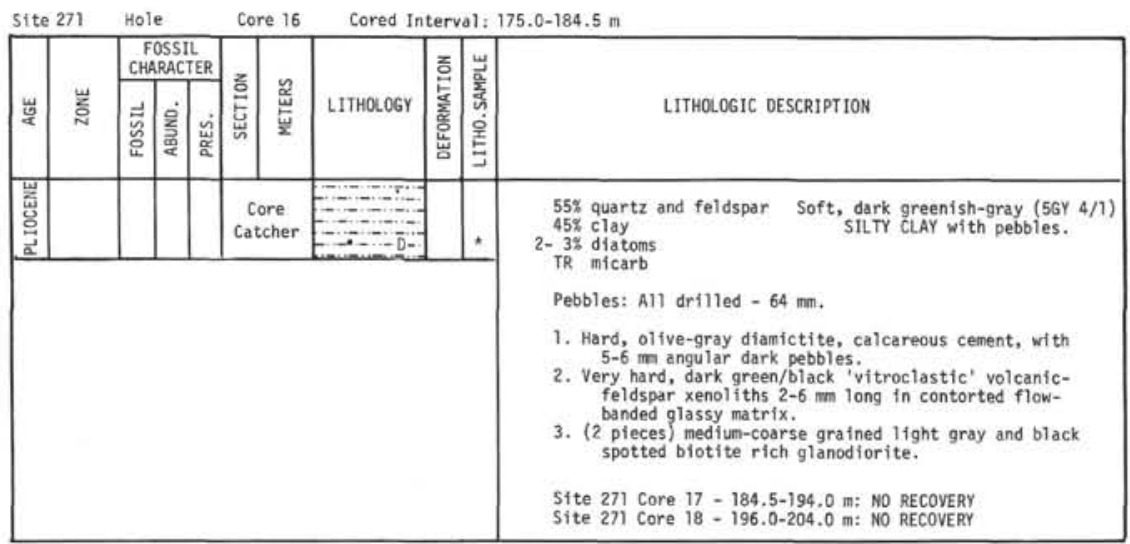

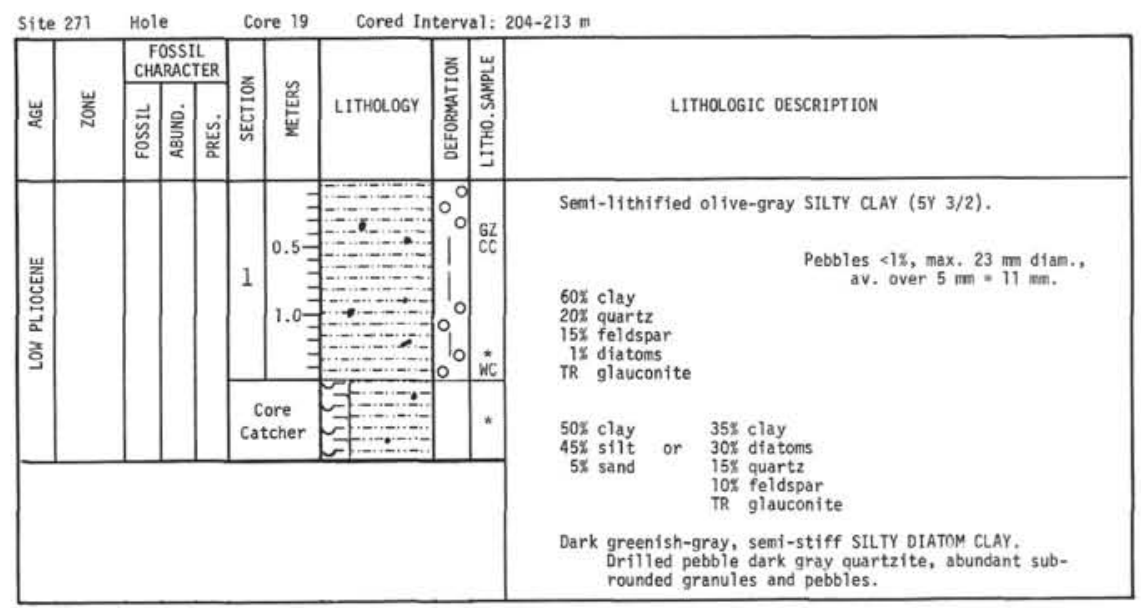

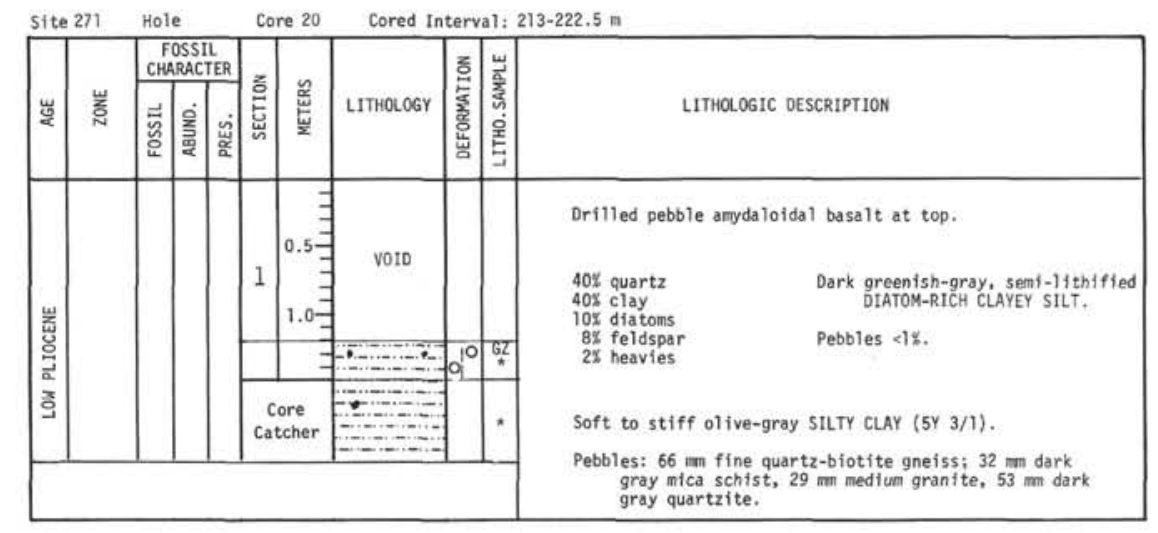

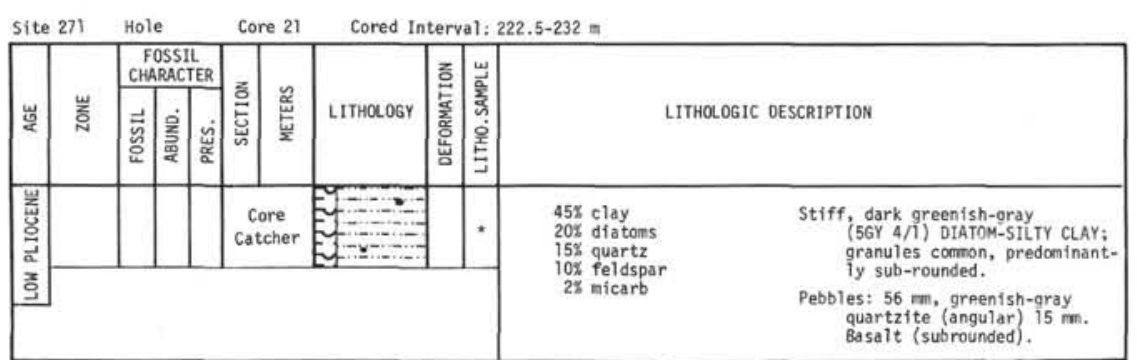




\begin{tabular}{|c|c|c|c|c|c|c|c|c|c|c|}
\hline Site & & Hole & & & re 22 & ed in & iterva & al: & $241.5 \mathrm{~m}$ & \\
\hline & & $\begin{array}{l}\text { FOS } \\
\text { CHAR }\end{array}$ & $\begin{array}{l}\text { SSIL } \\
\text { SACTER }\end{array}$ & & & & z & | & & \\
\hline 崖 & 訔 & 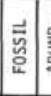 & & 总 & $\stackrel{\frac{2}{4}}{\frac{2}{2}}$ & LITHOLOGY & 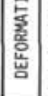 & 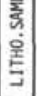 & & SCRIPTION \\
\hline & & & & & & & & & Pebbles ?grar & ay quartzite, to $91 \mathrm{~mm}$ diam. \\
\hline 㟥 & & & & 1 & & & & & $\begin{array}{l}\text { 44X clay } \\
258 \text { datatoms } \\
162 \text { quartz }\end{array}$ & $\begin{array}{l}\text { Pebbly drilling slude. Dark } \\
\text { greenish-gray }(56 \mathrm{Gr} \text { (3) } \\
\text { SILTY DIATOM CLAY. }\end{array}$ \\
\hline 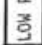 & & & & & & $y^{2}-a$ & & $\cdot$ & $\begin{array}{l}10 \% \text { feldssar } \\
2 \% \text { micarb }\end{array}$ & \\
\hline
\end{tabular}

Site 271 Hole Core 23 Cored Interva1: 241.5-251 m

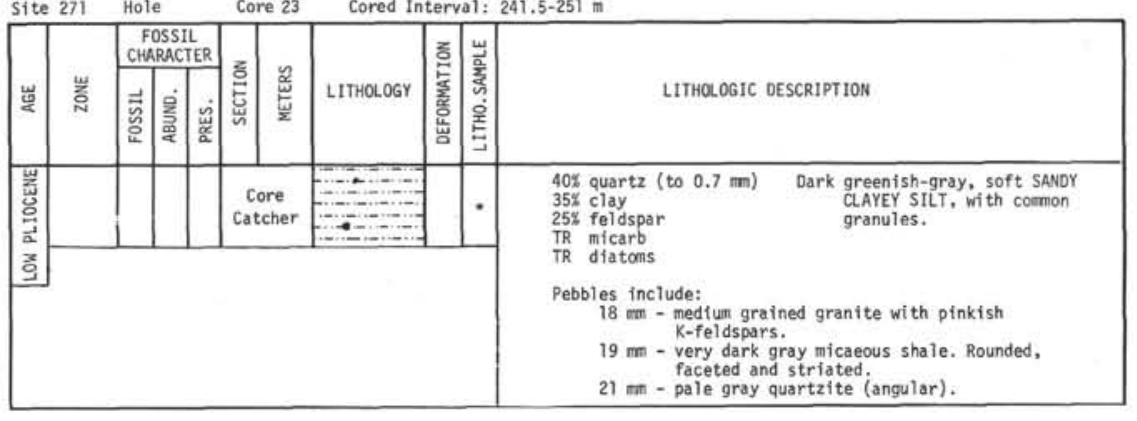

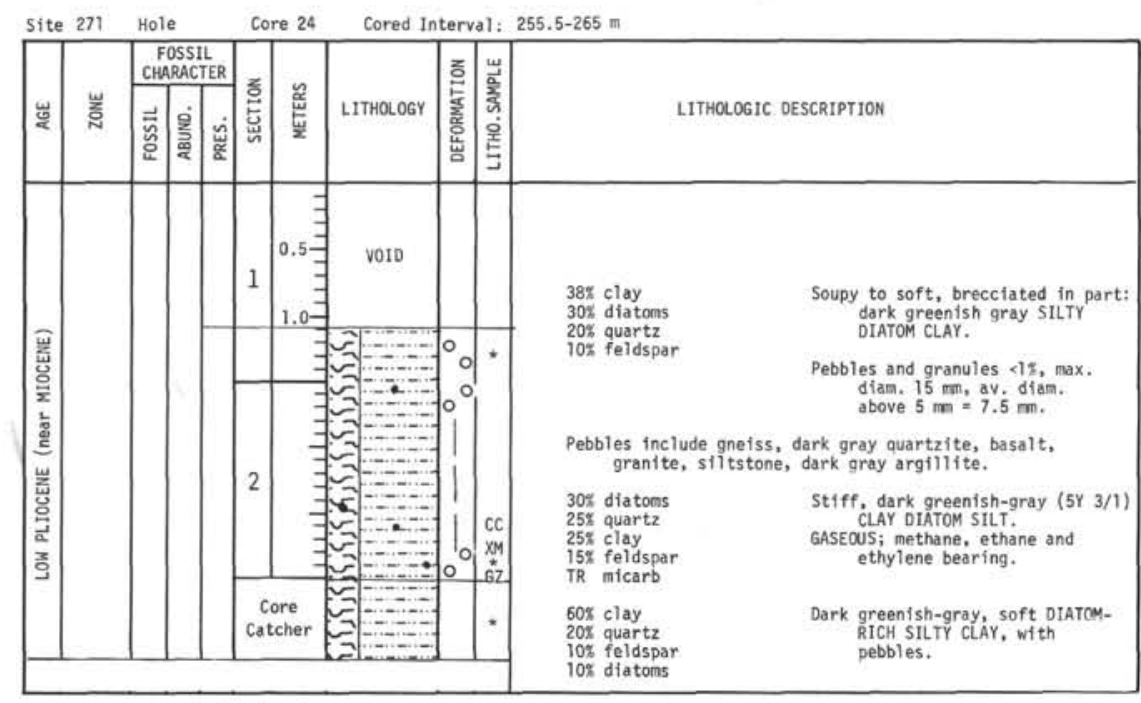

Explanatory notes in Chapter 1 


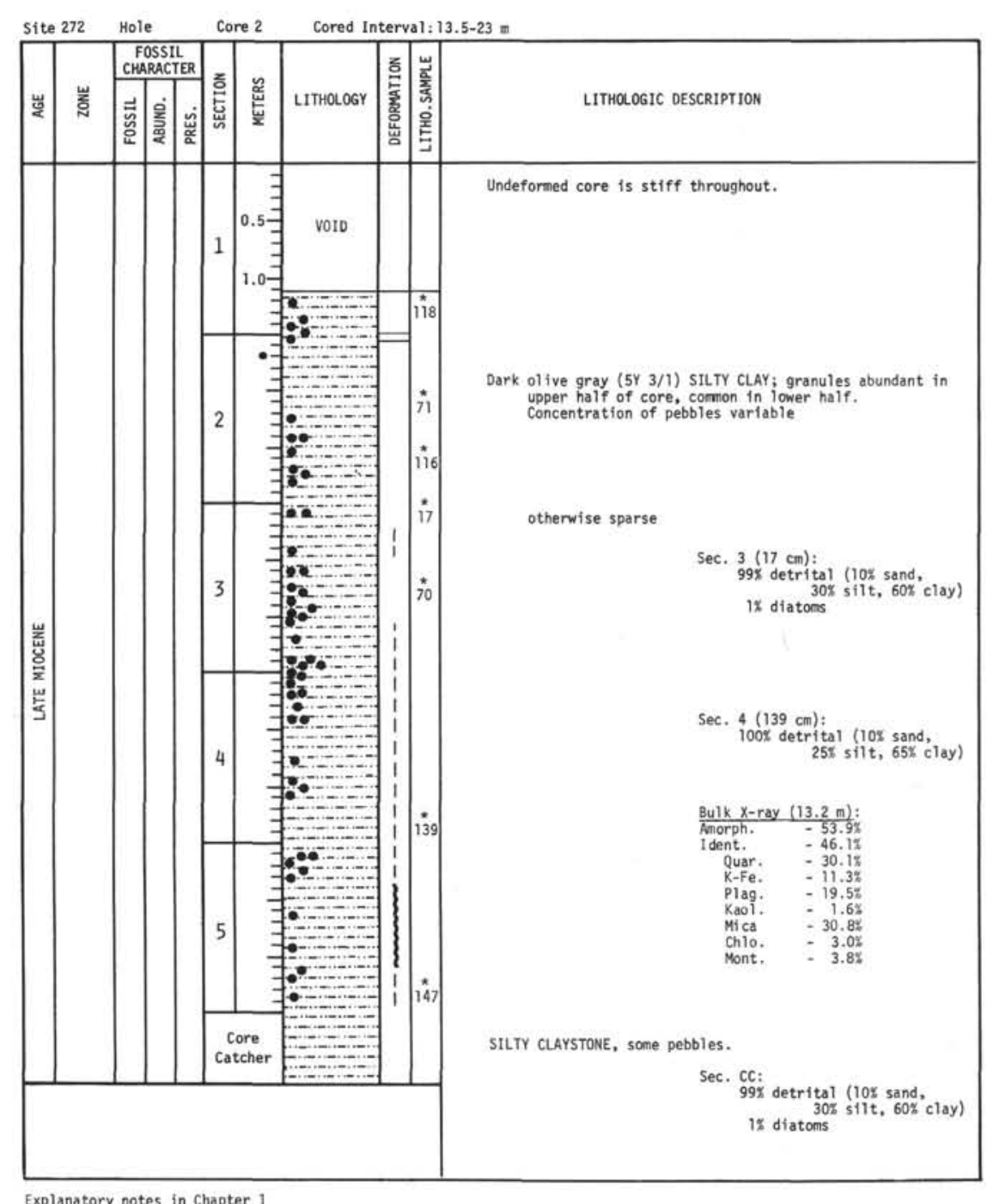




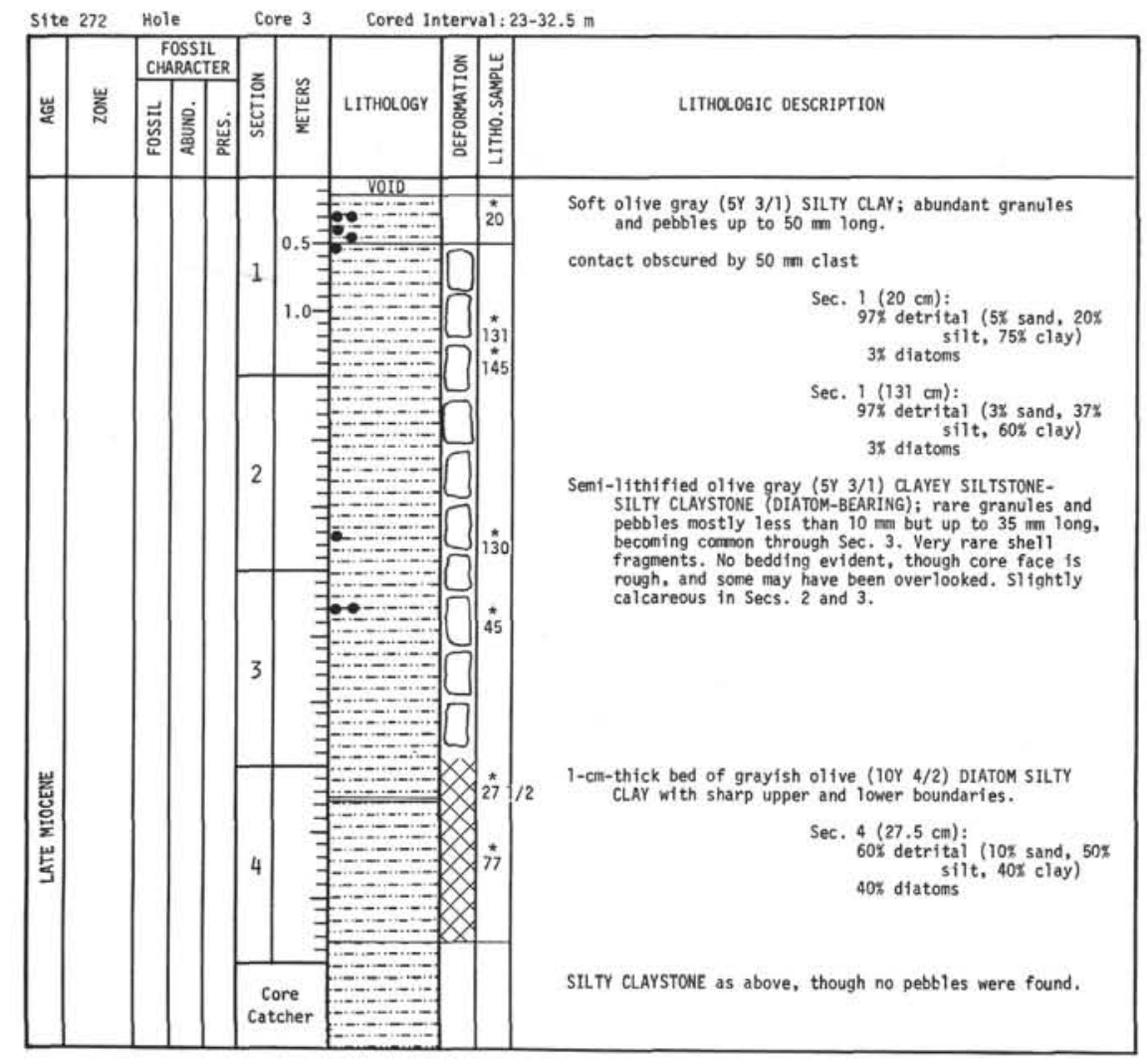




\begin{tabular}{|l|l|l|l|l|l|l|l|l|}
\hline Site 272 & Hole \\
\hline
\end{tabular}

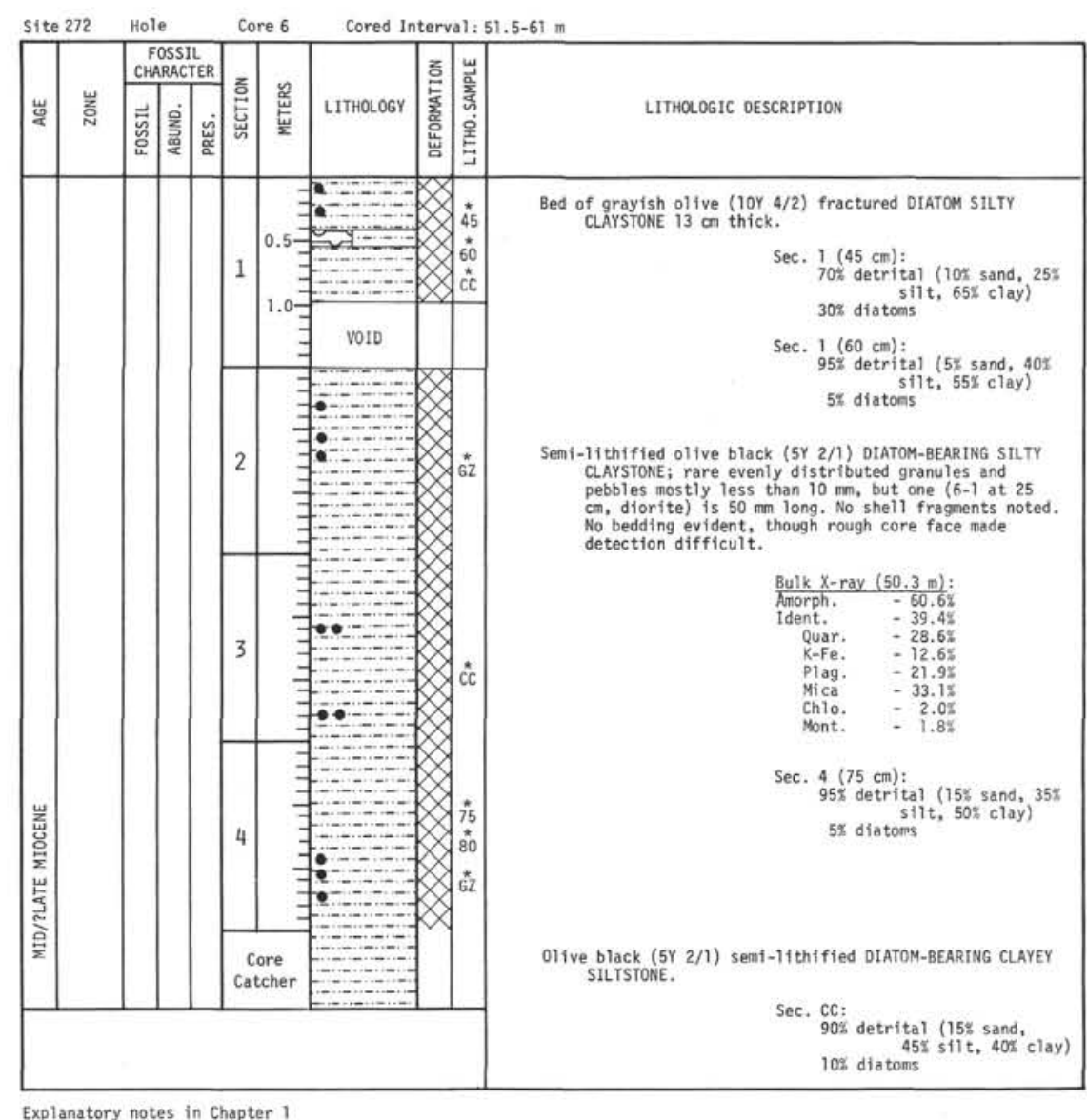




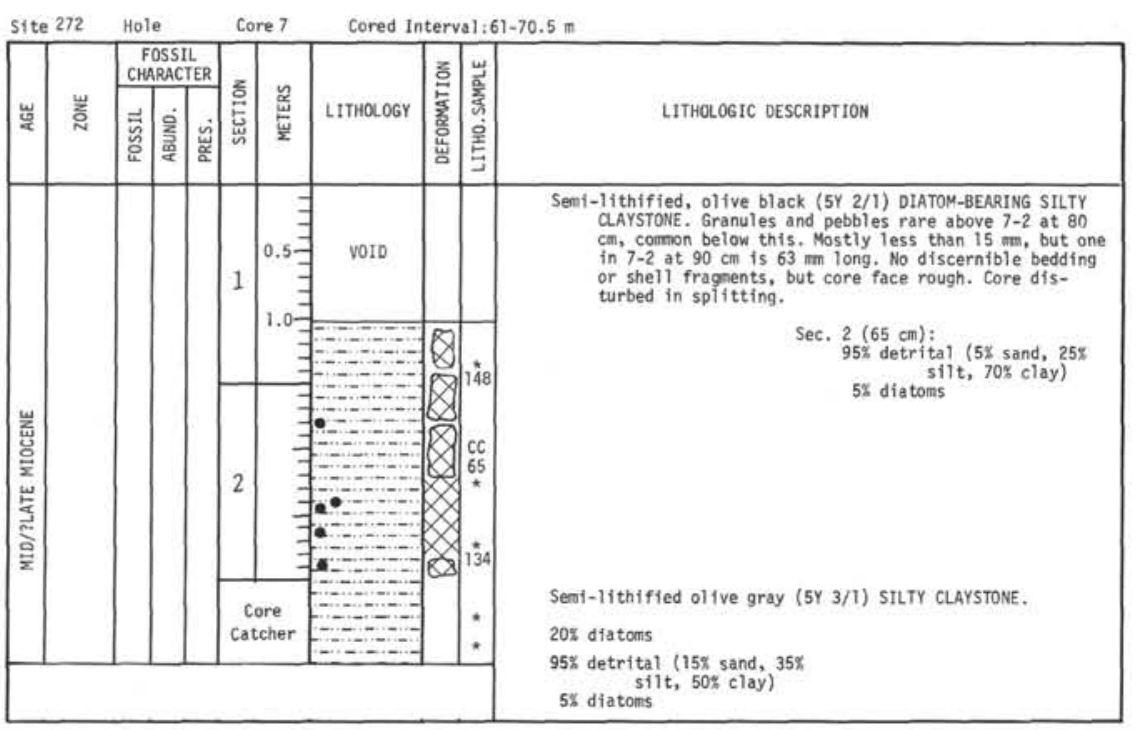




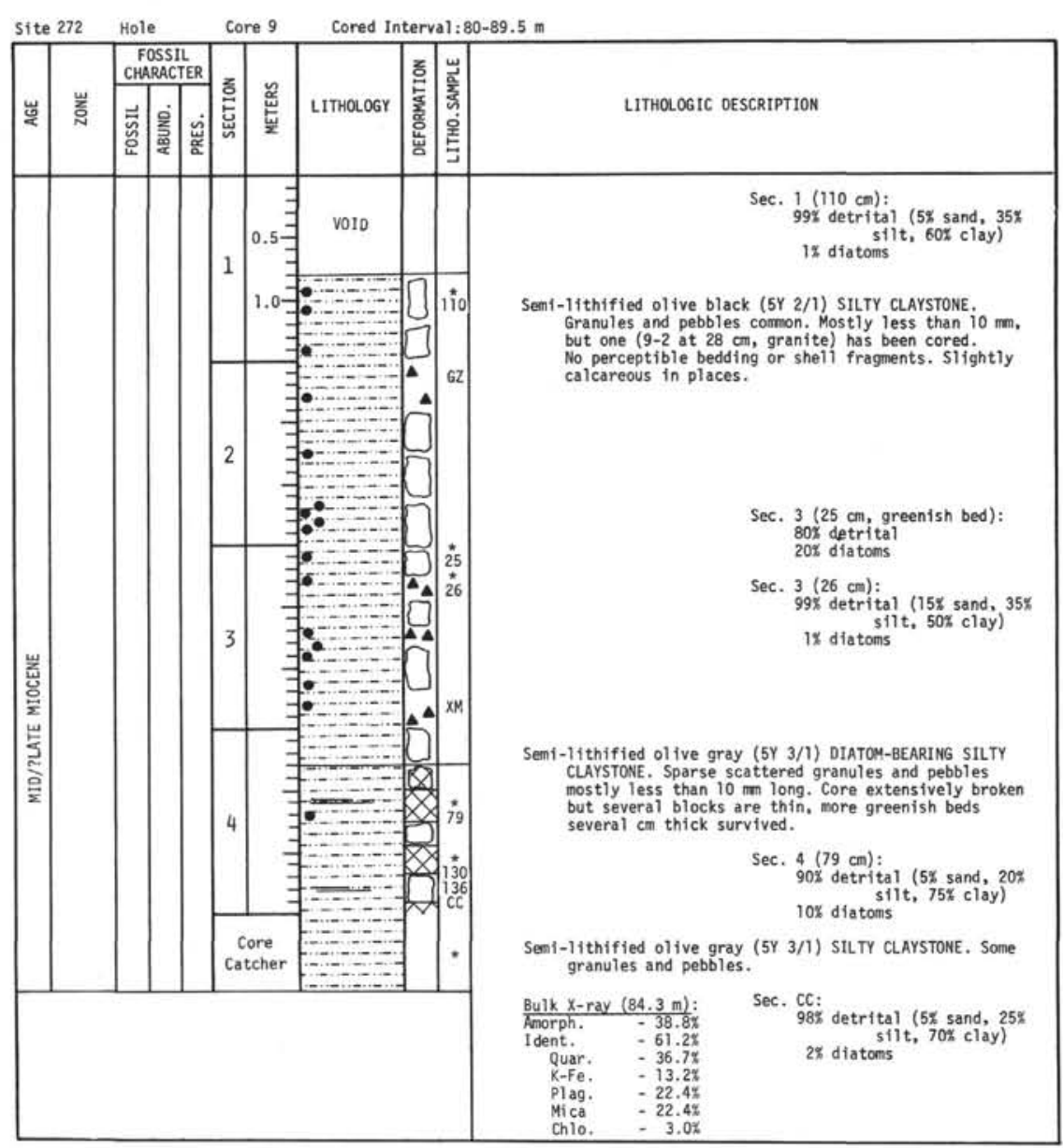

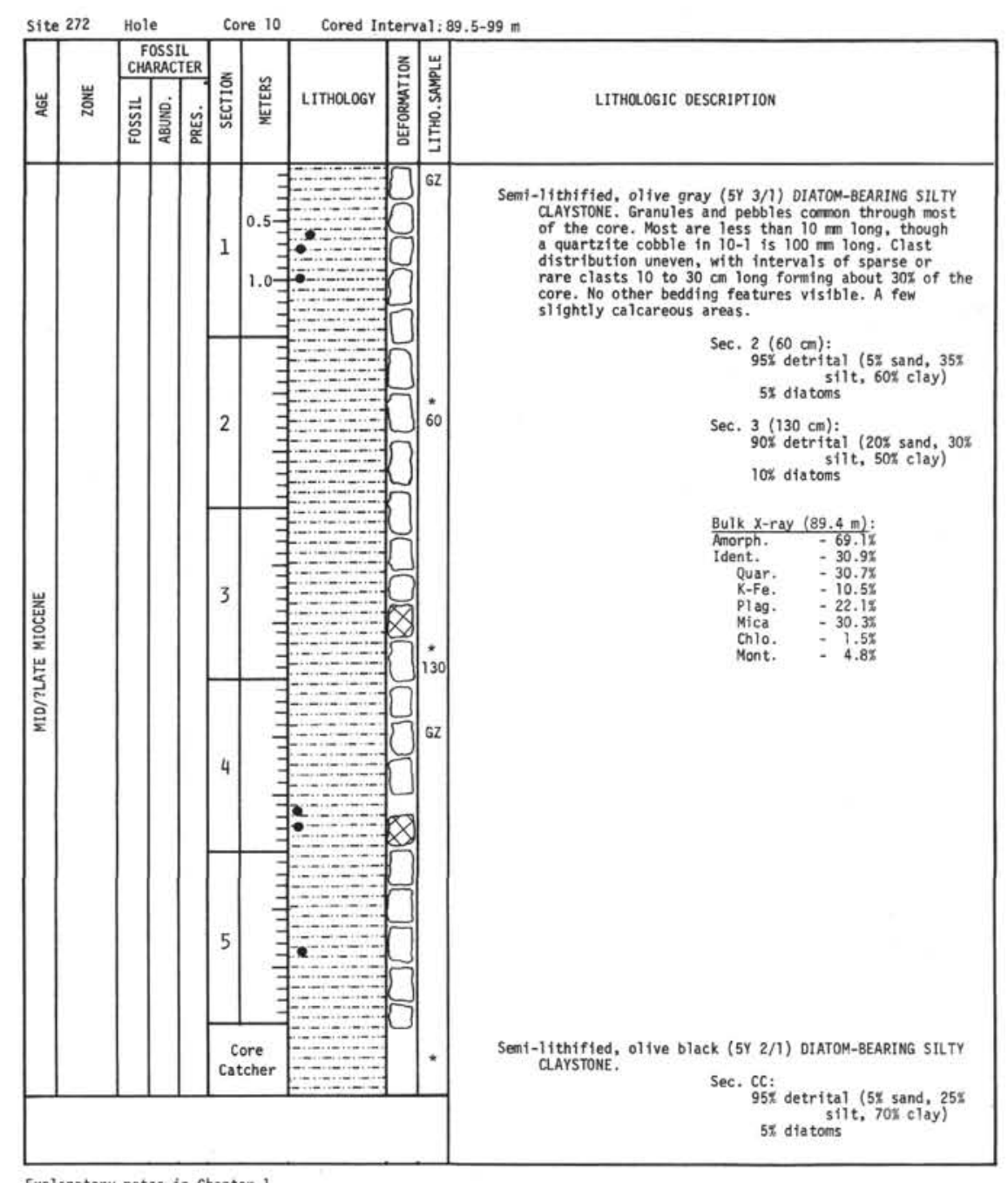




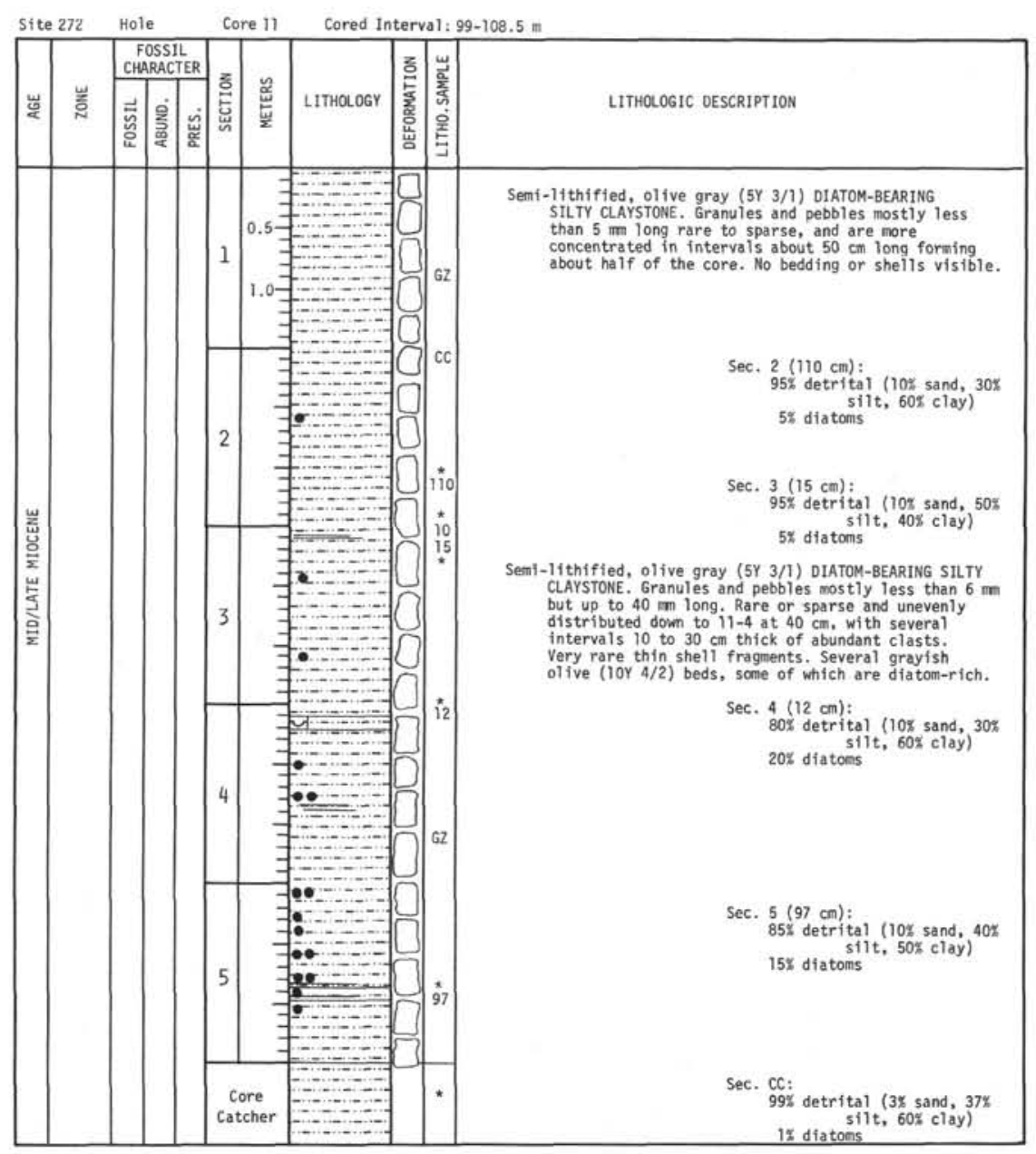

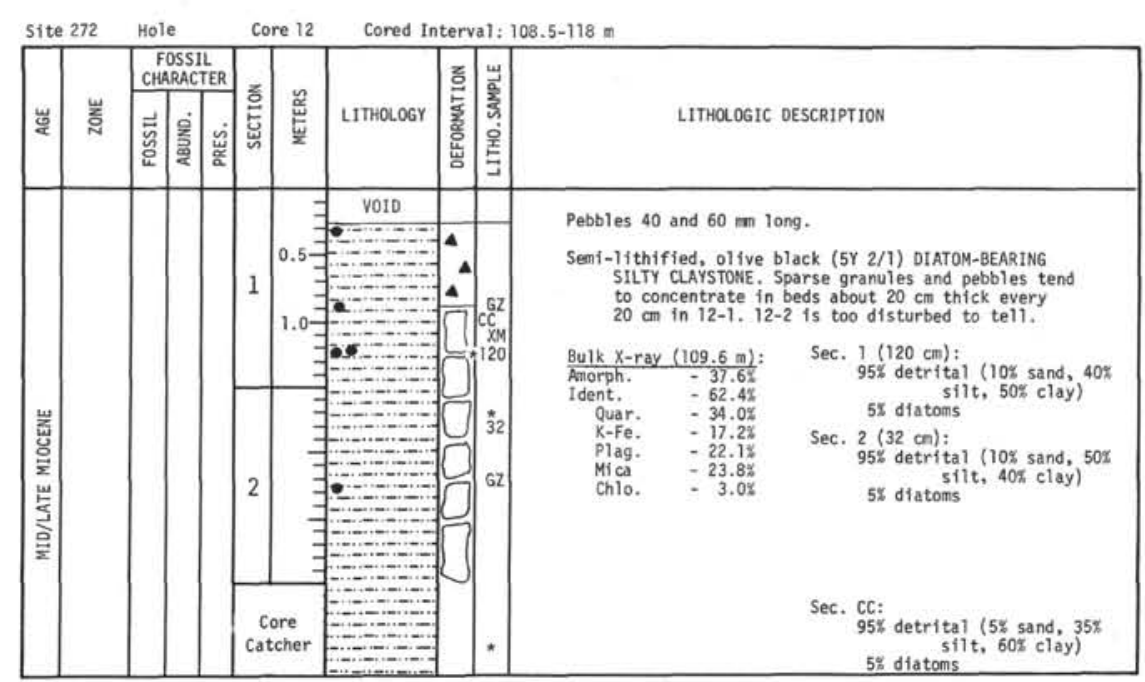

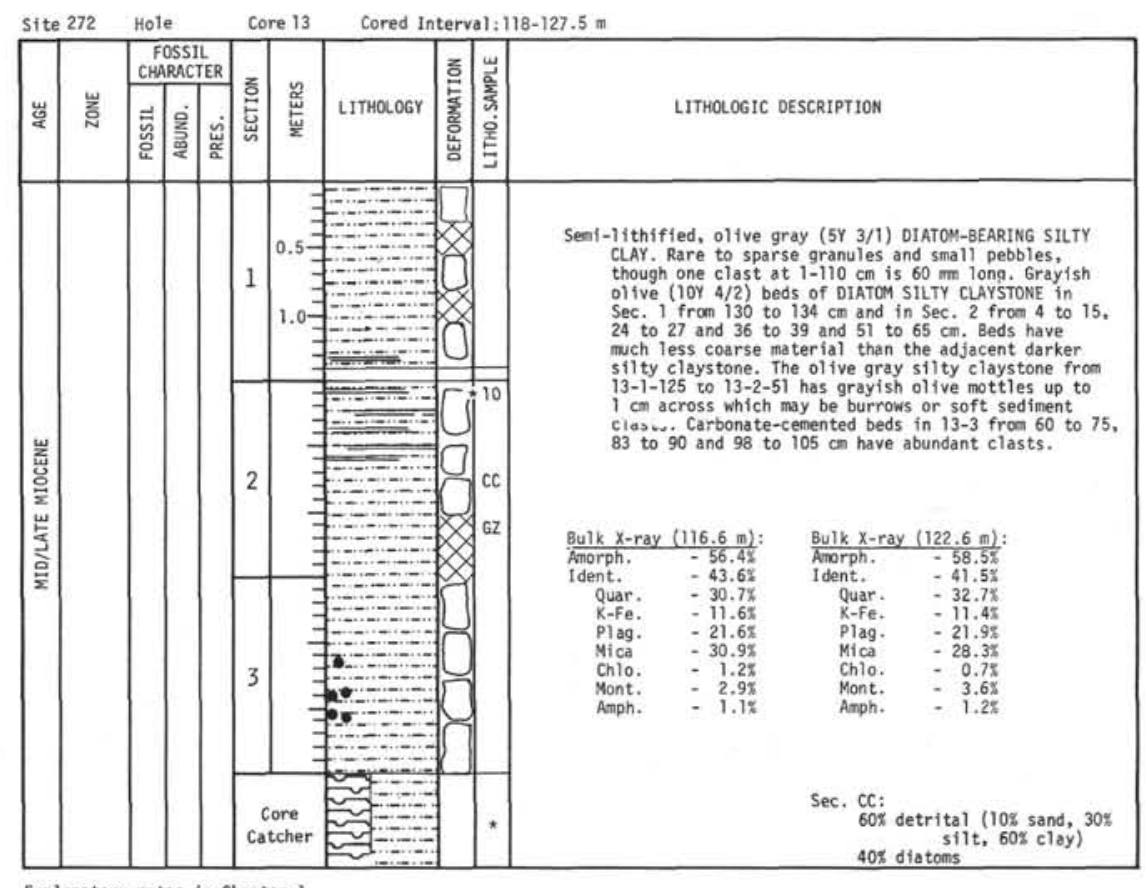




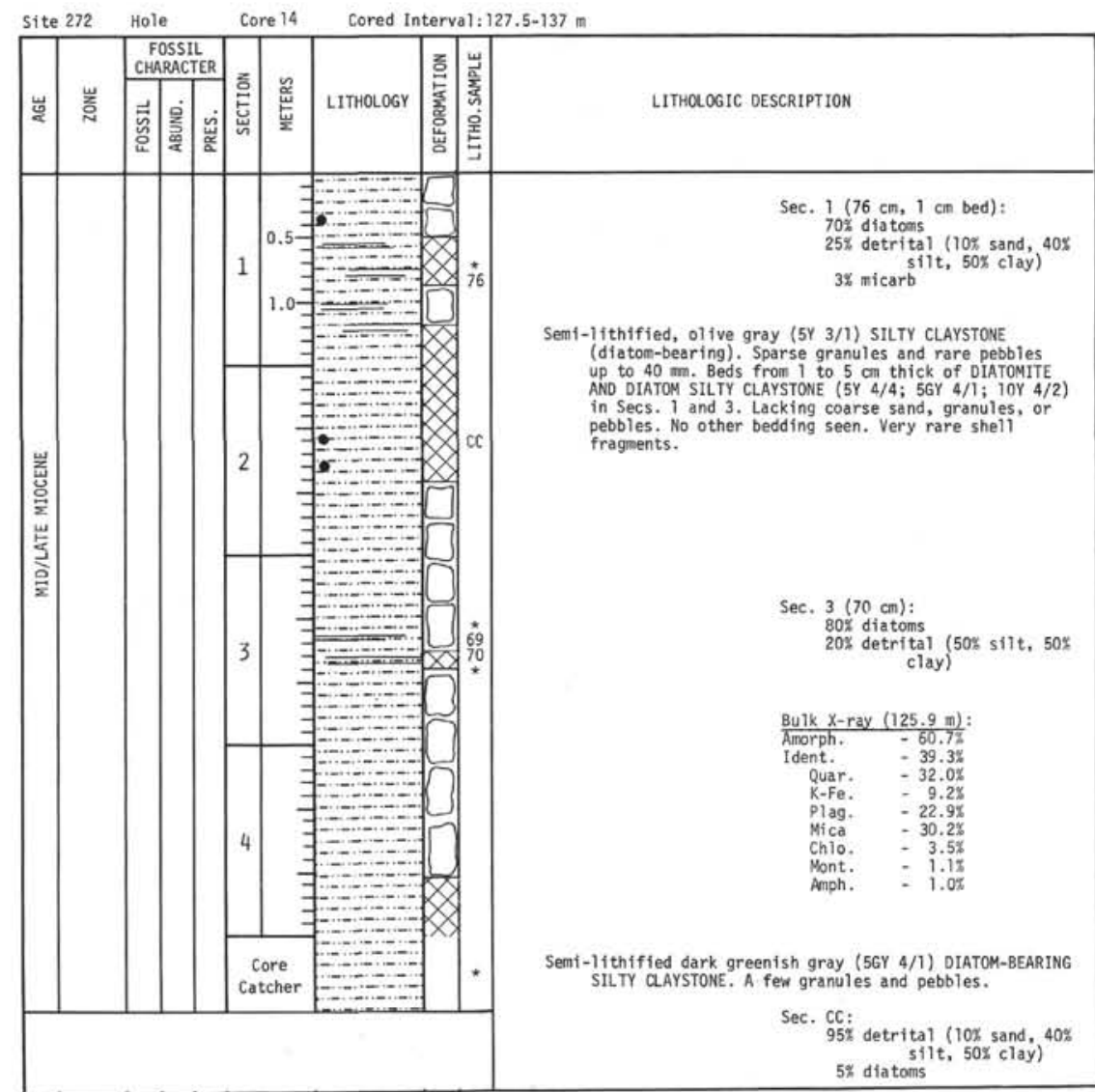

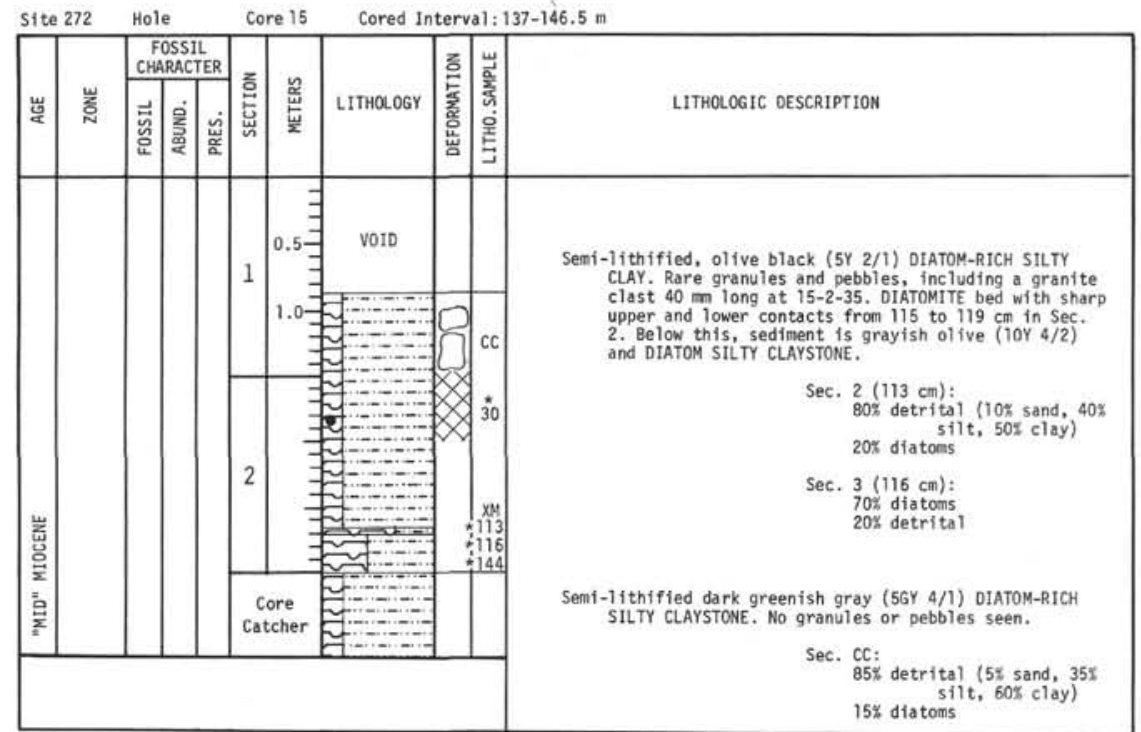

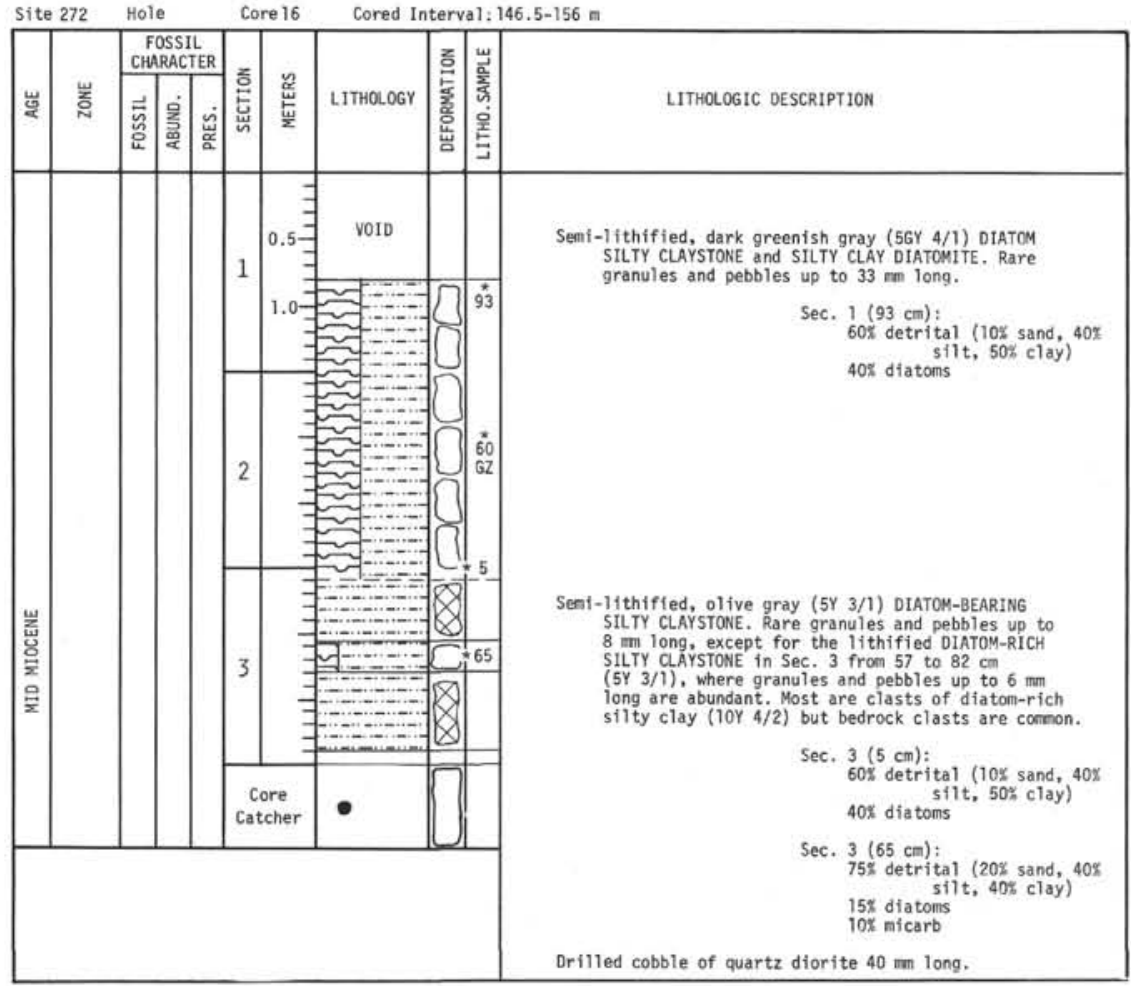




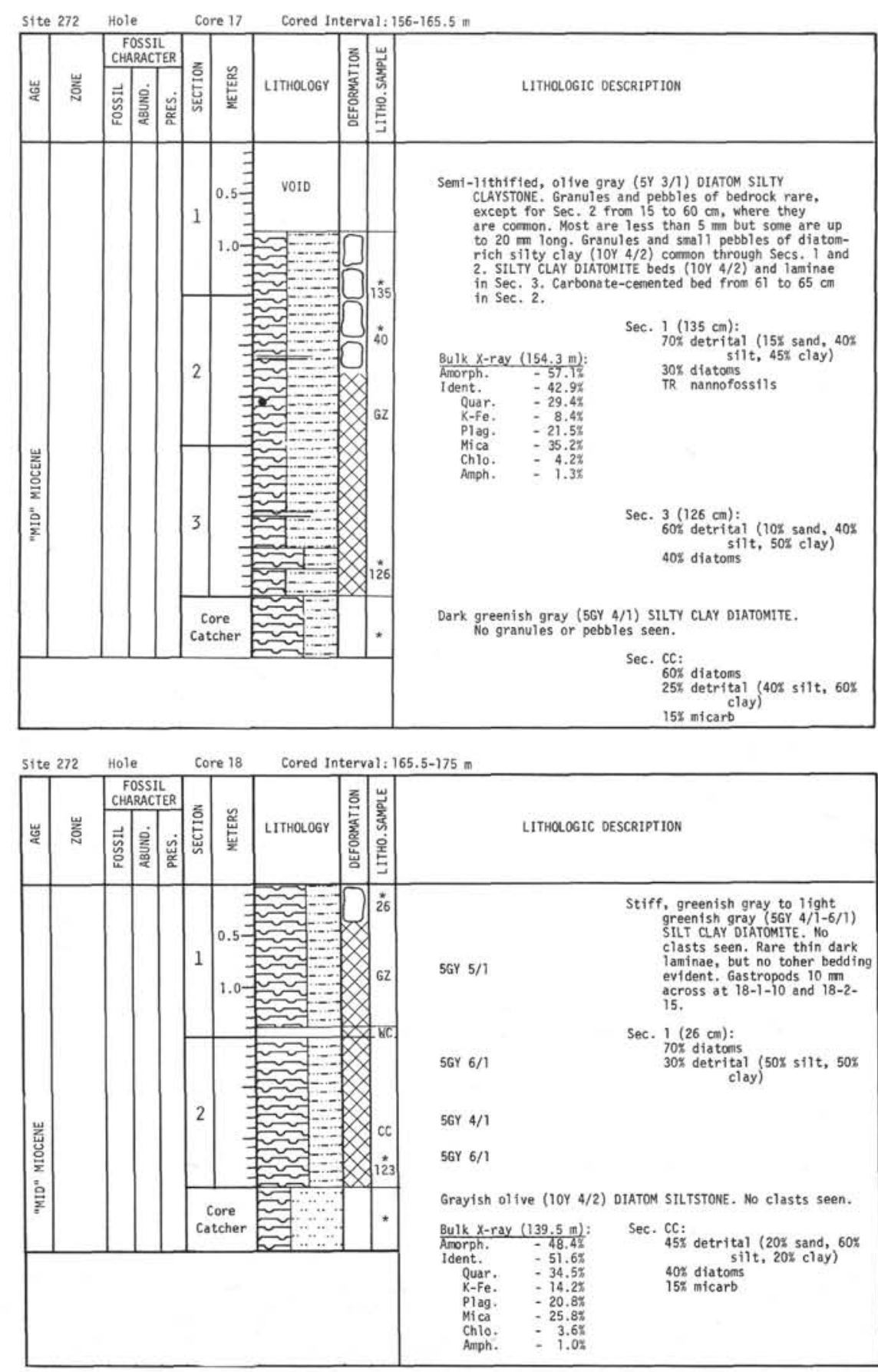

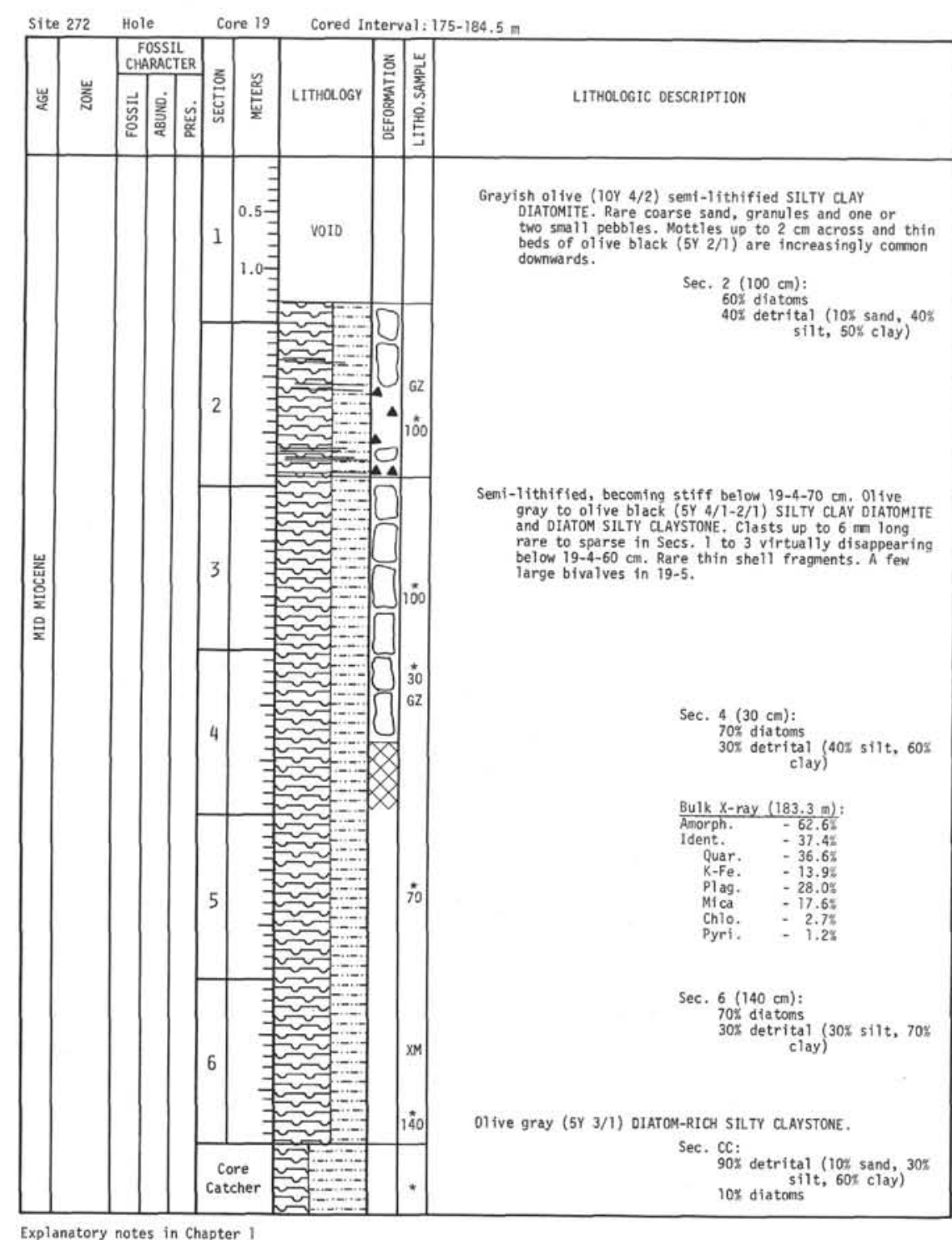




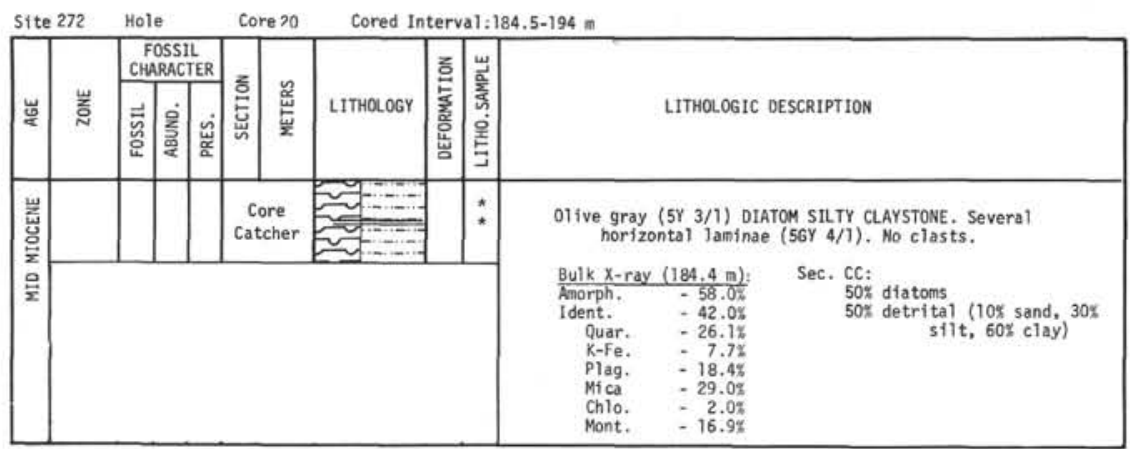

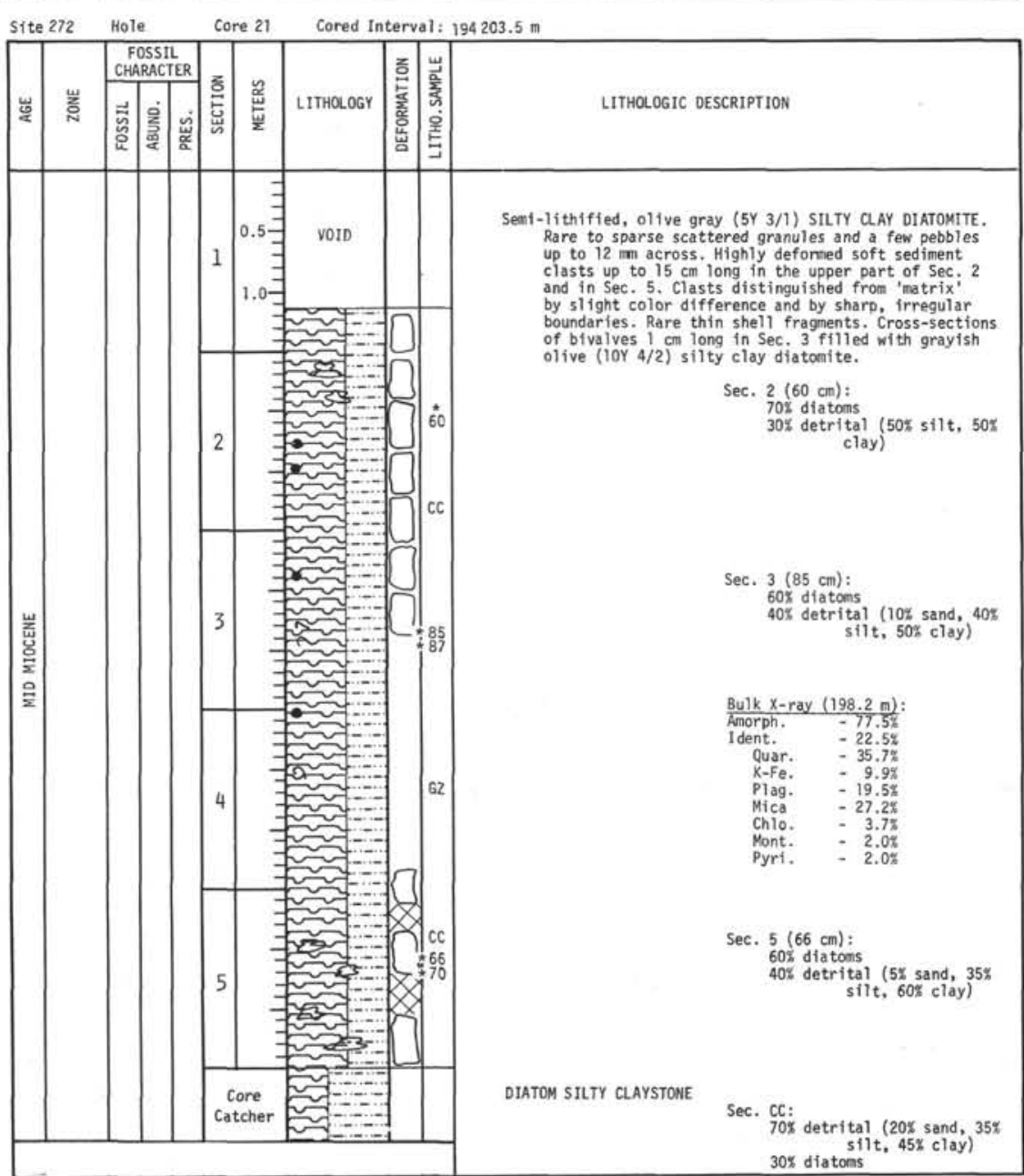

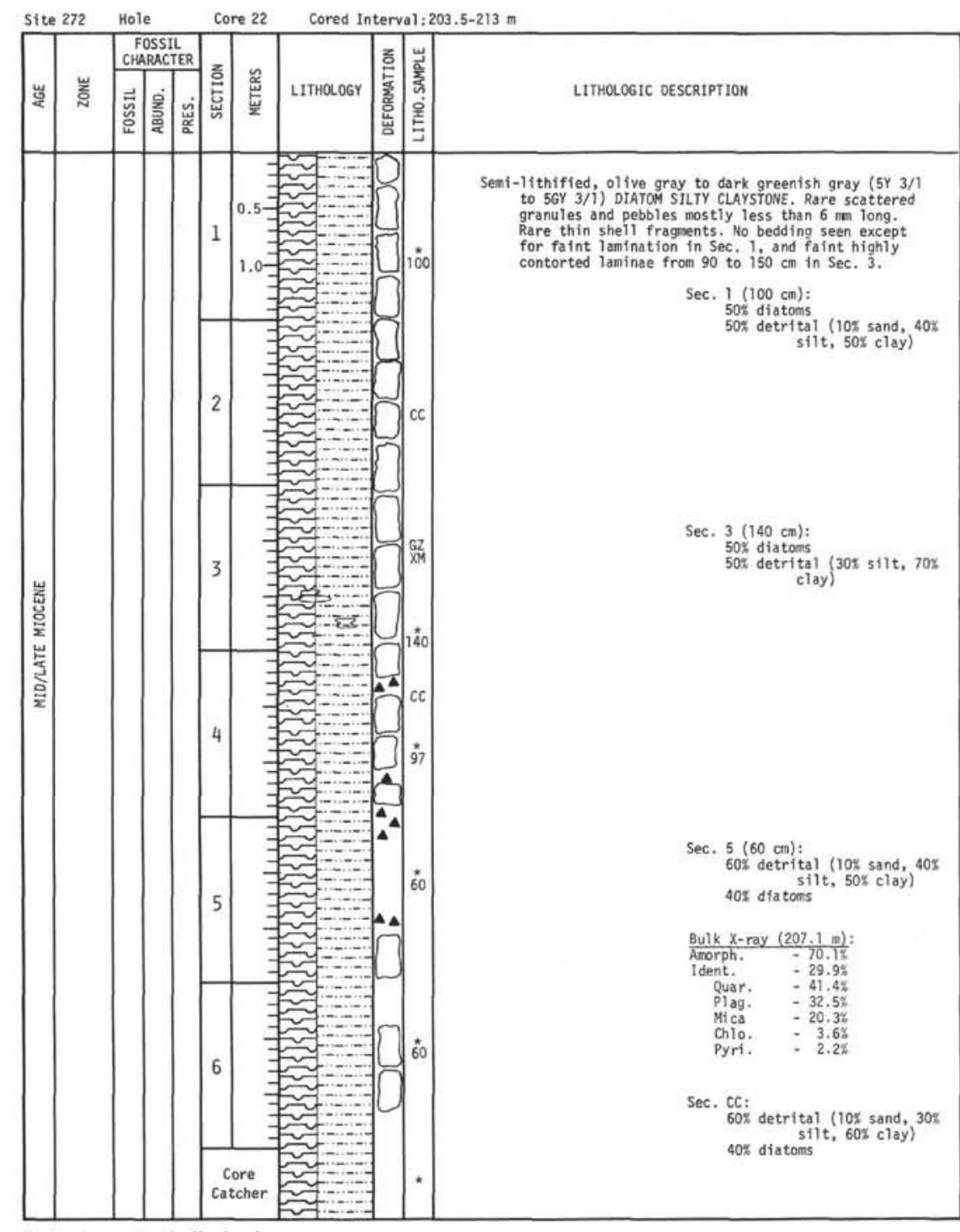




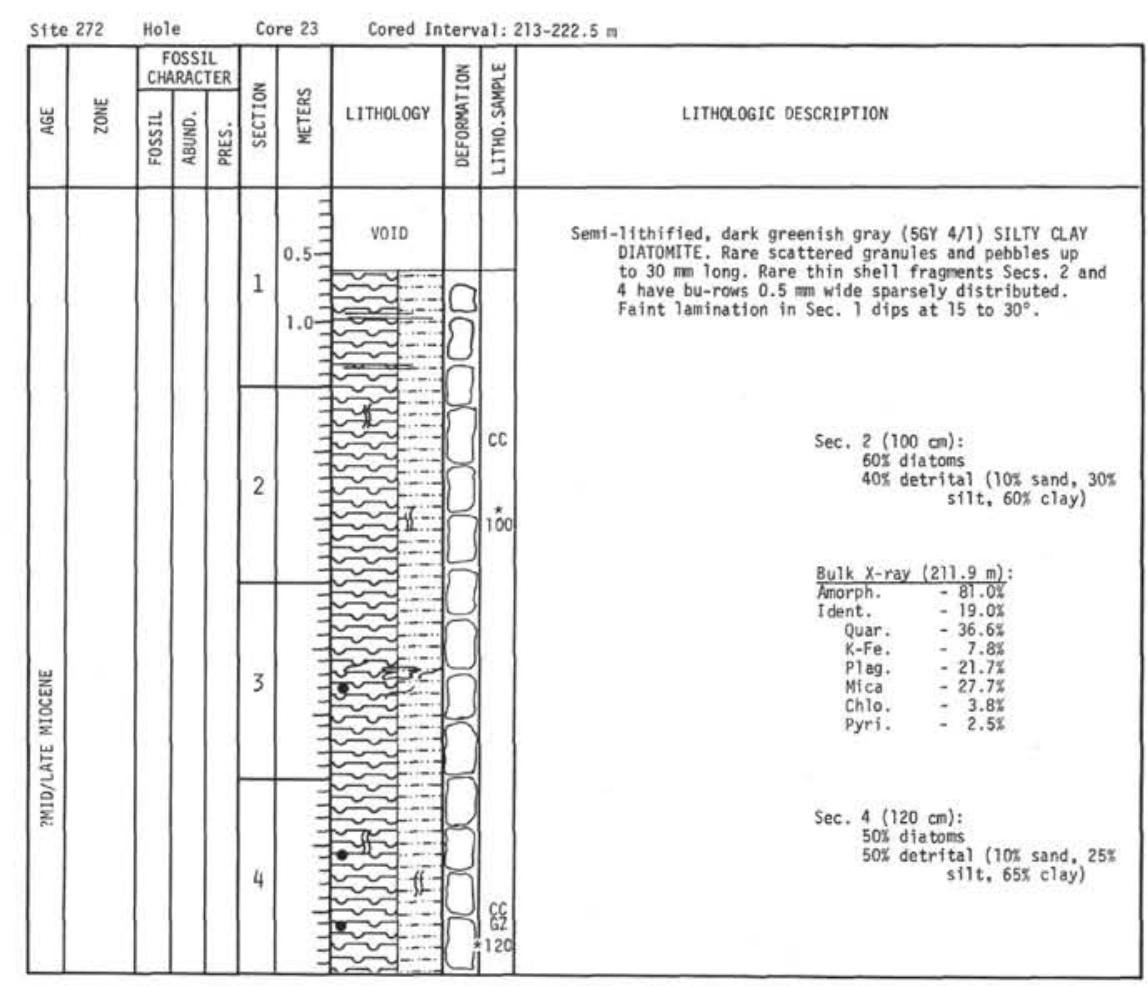

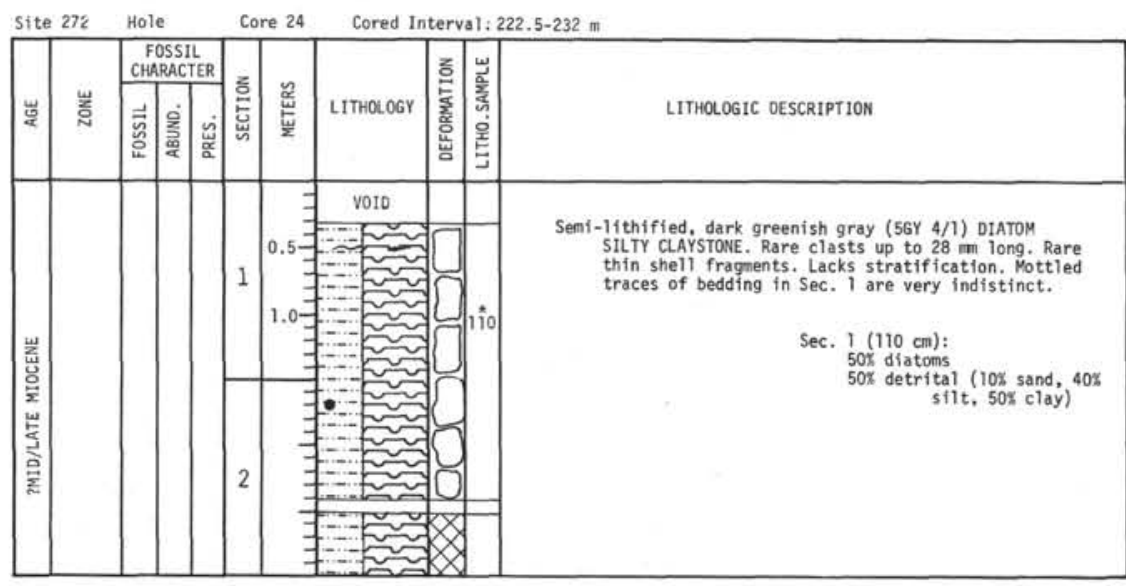

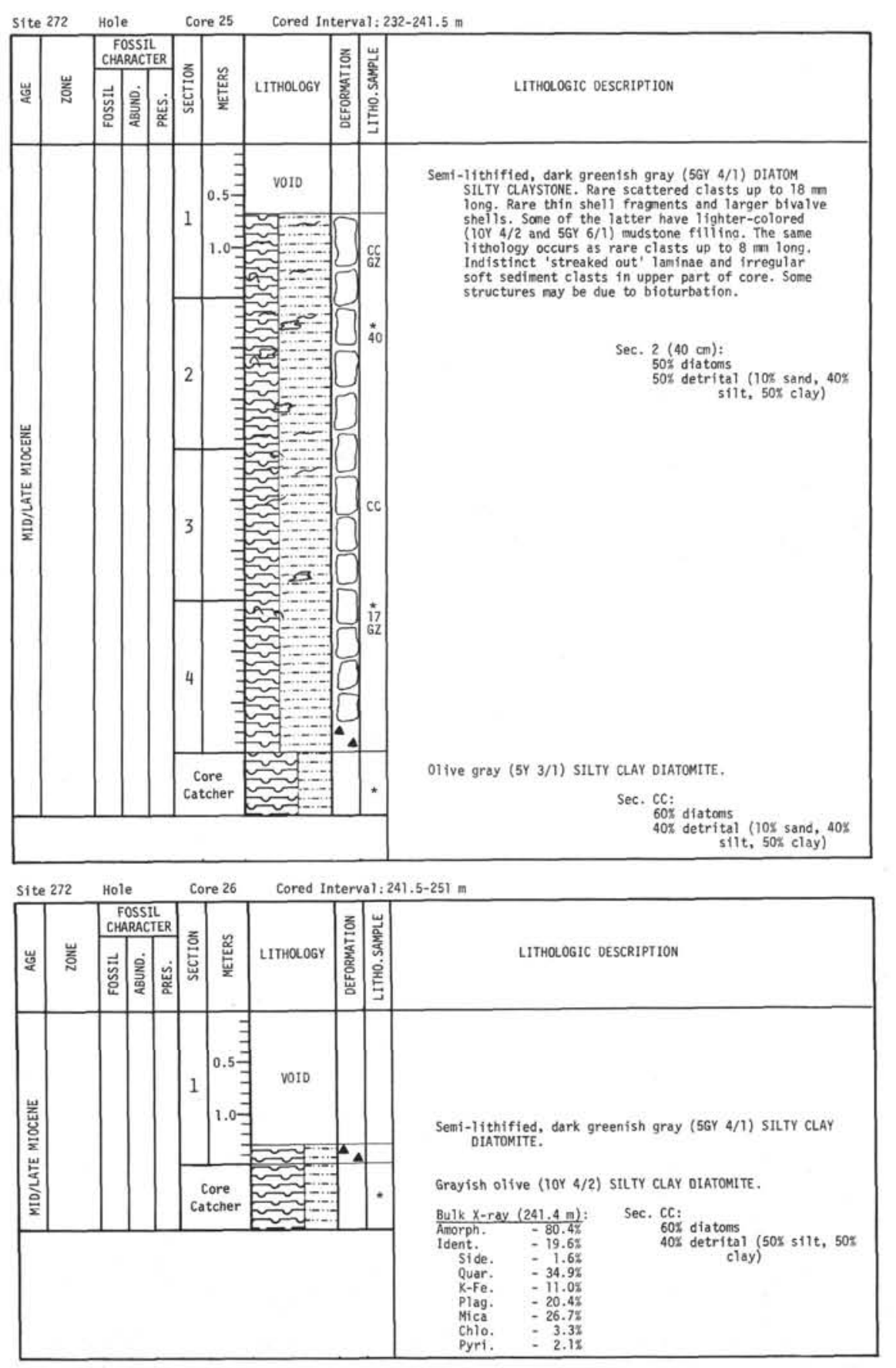

Explanatory notes in Chapter 1 


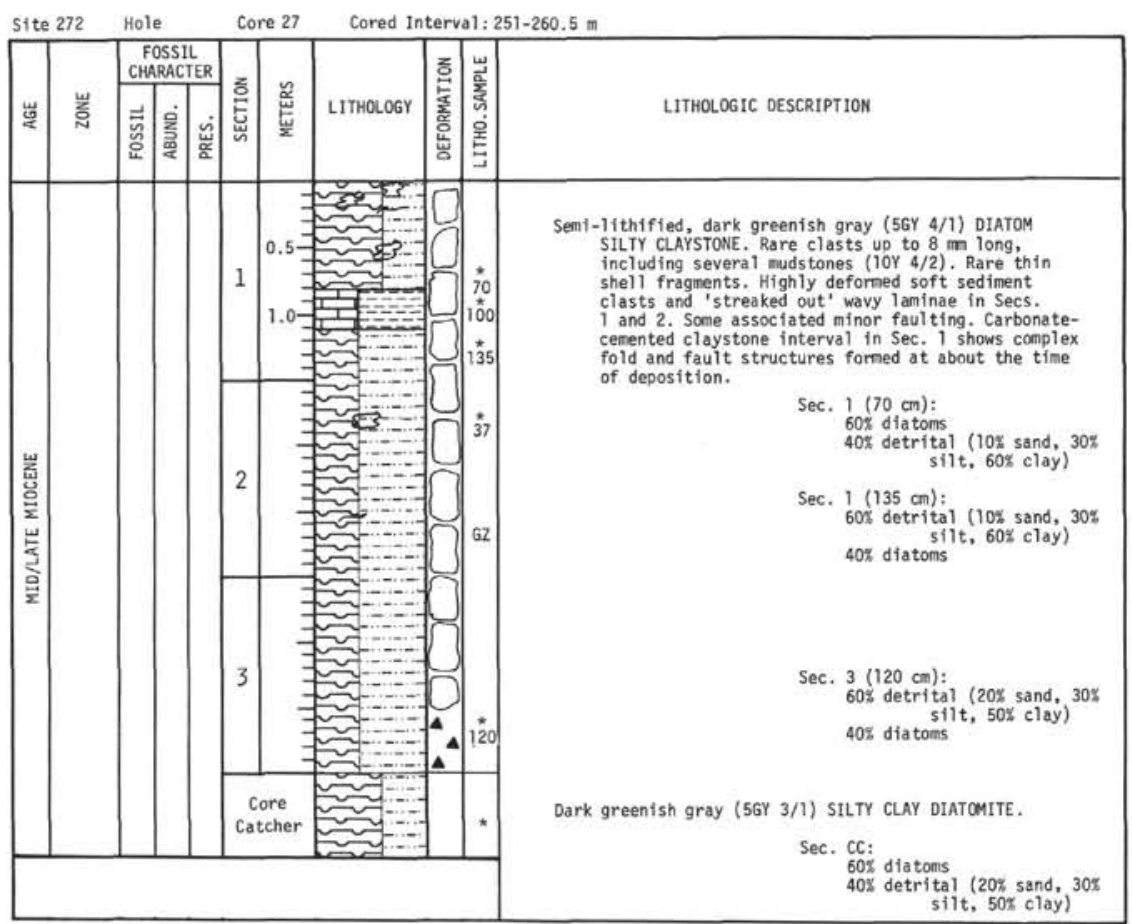

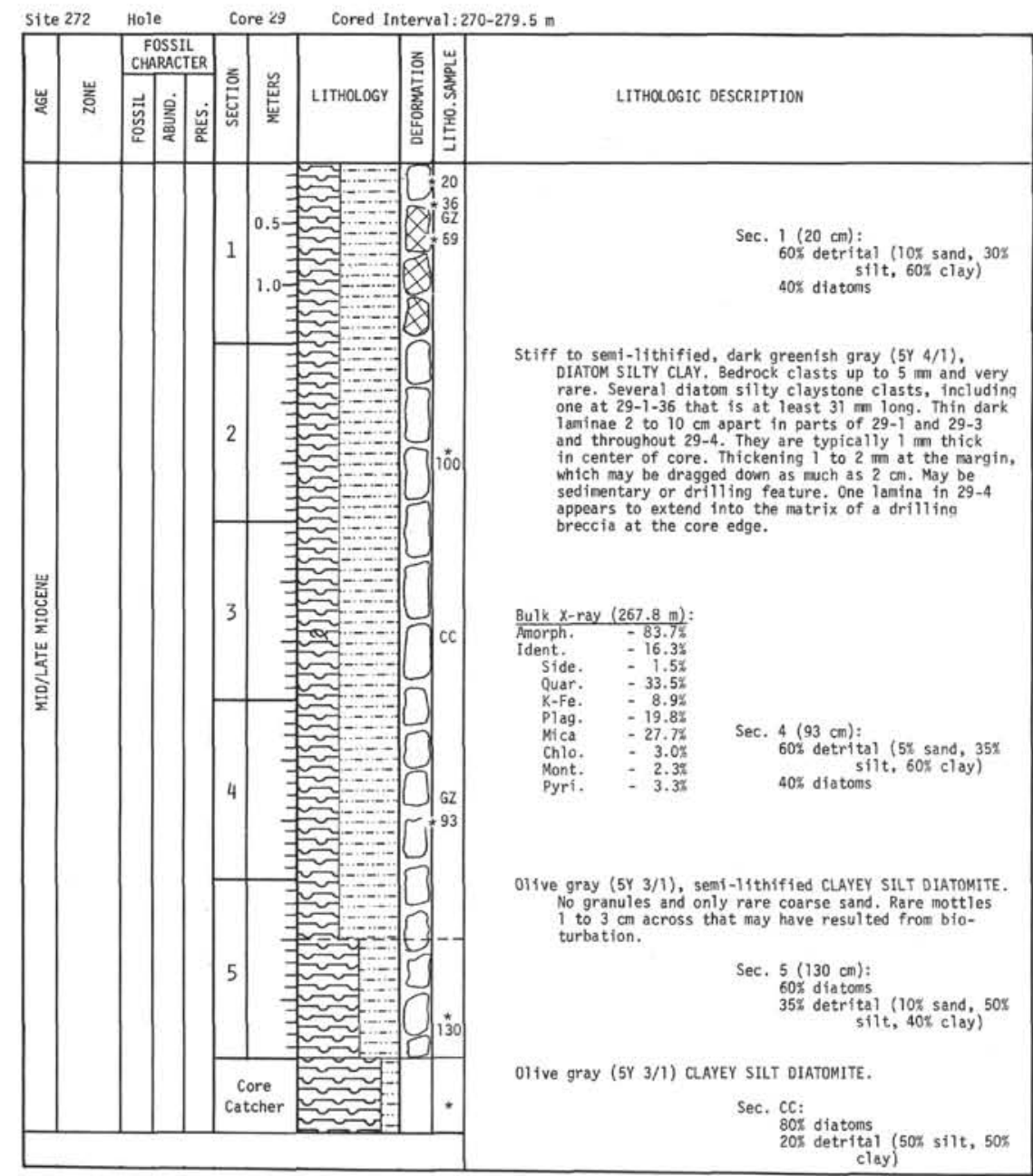

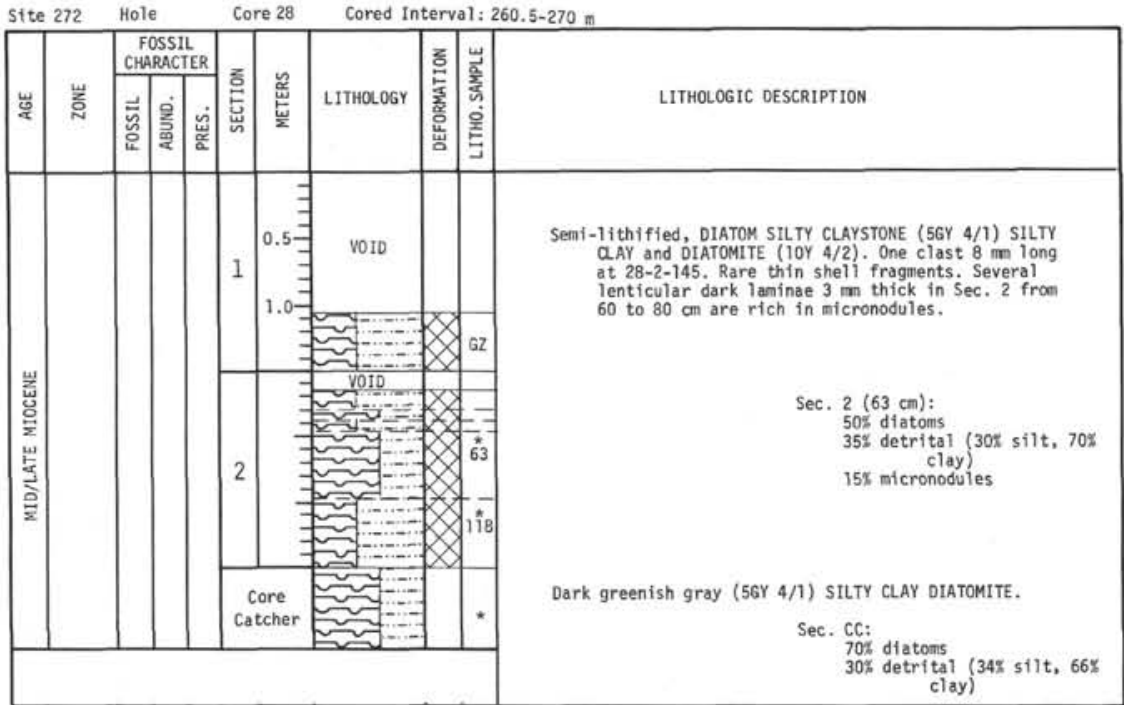



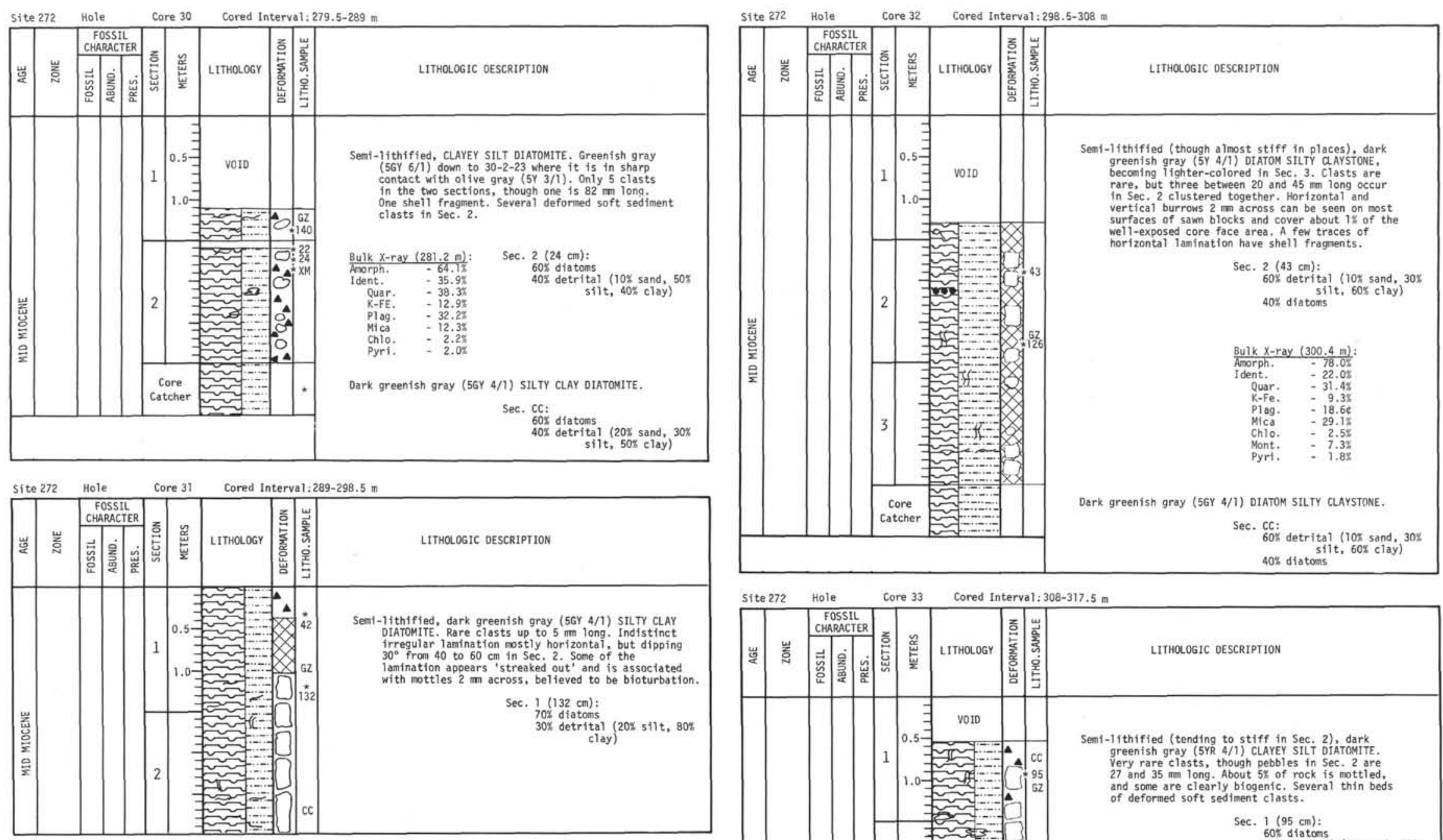

\begin{tabular}{|c|c|c|c|c|c|c|}
\hline T & & Hole & Core & Cored In & terval: 3 & $177.5 \mathrm{~m}$ \\
\hline | & 言 & 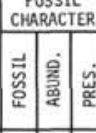 & 悹 & LITHOLoG & 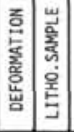 & LITHOOGIC DESCRIPTION \\
\hline & & & 1 & . & 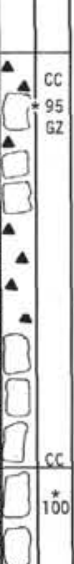 & 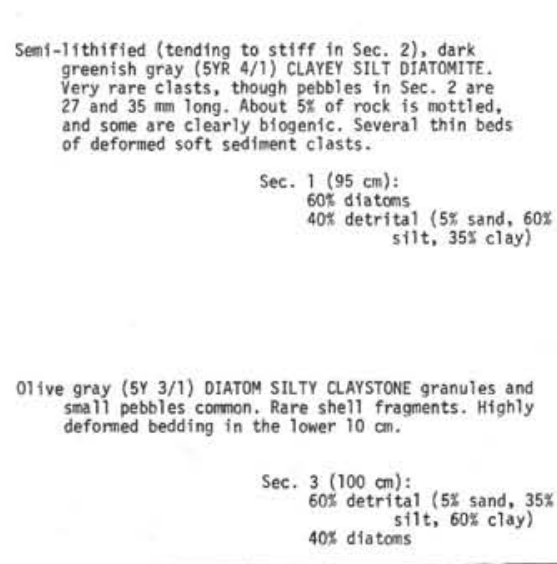 \\
\hline
\end{tabular}




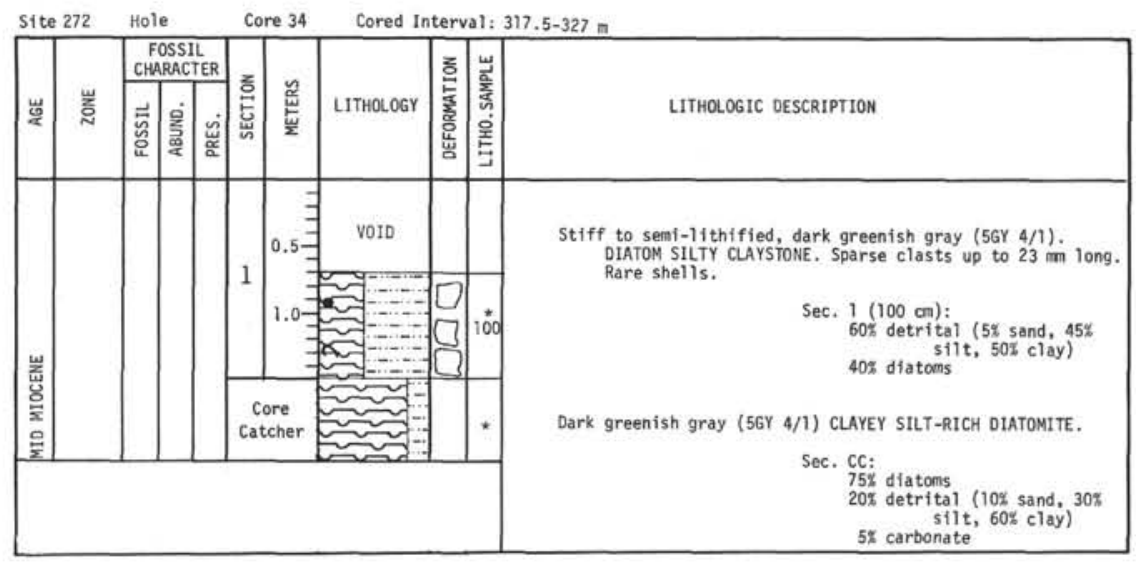

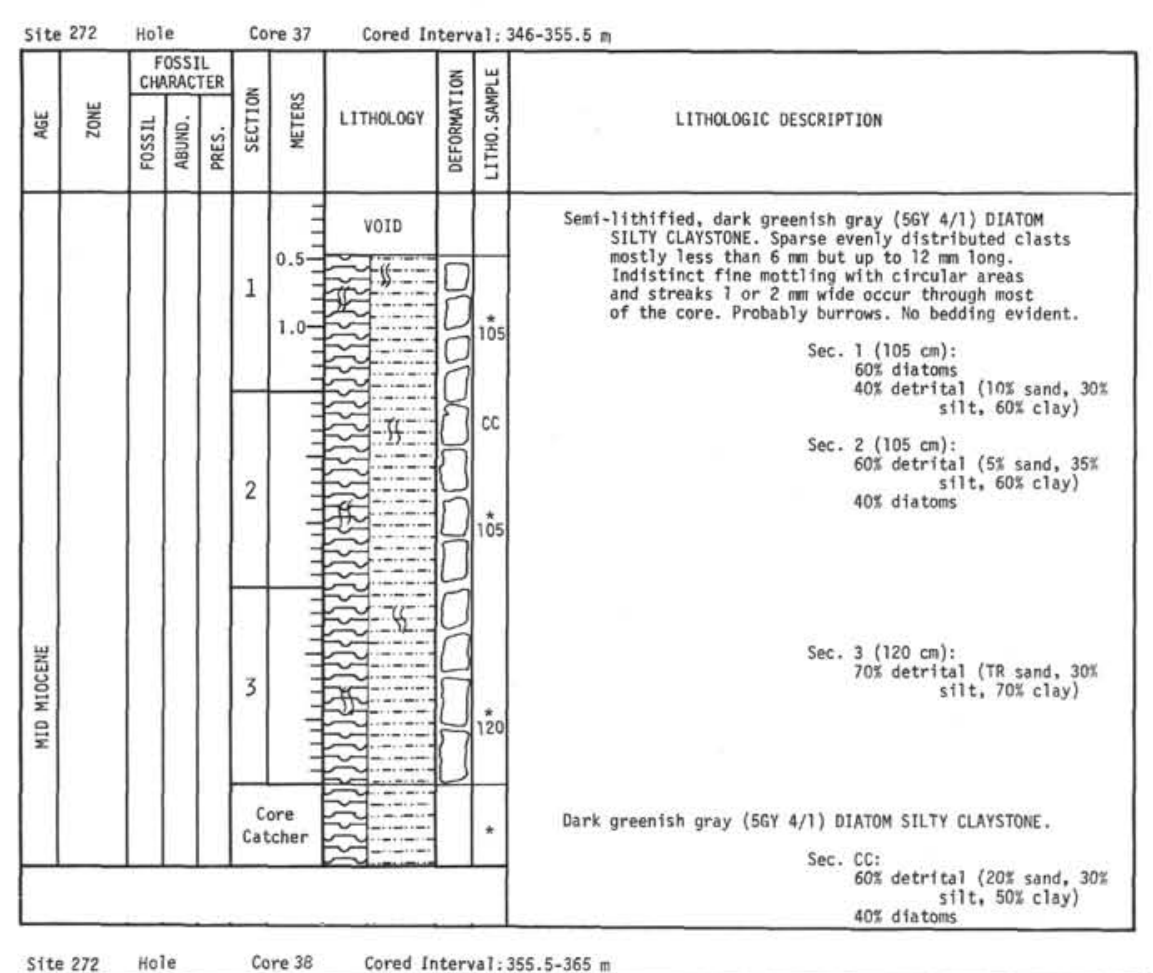

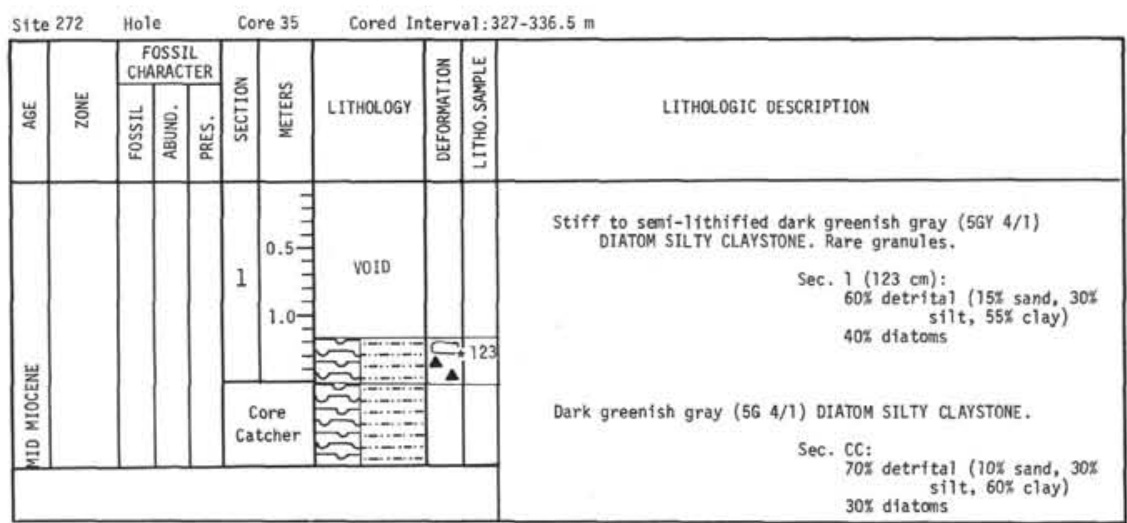

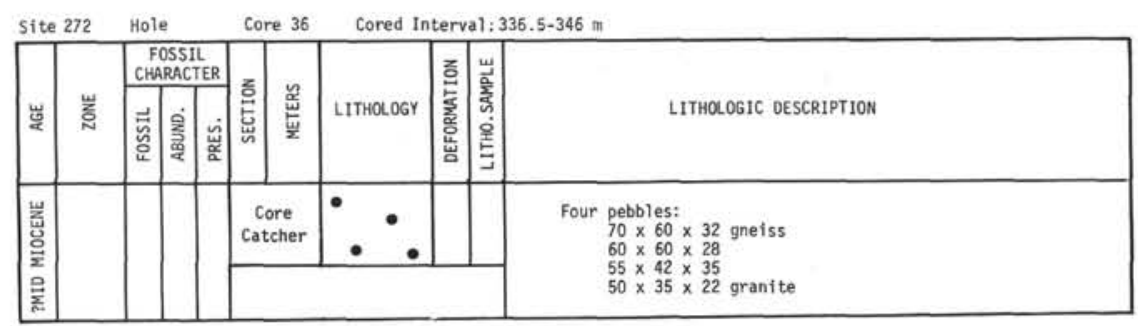

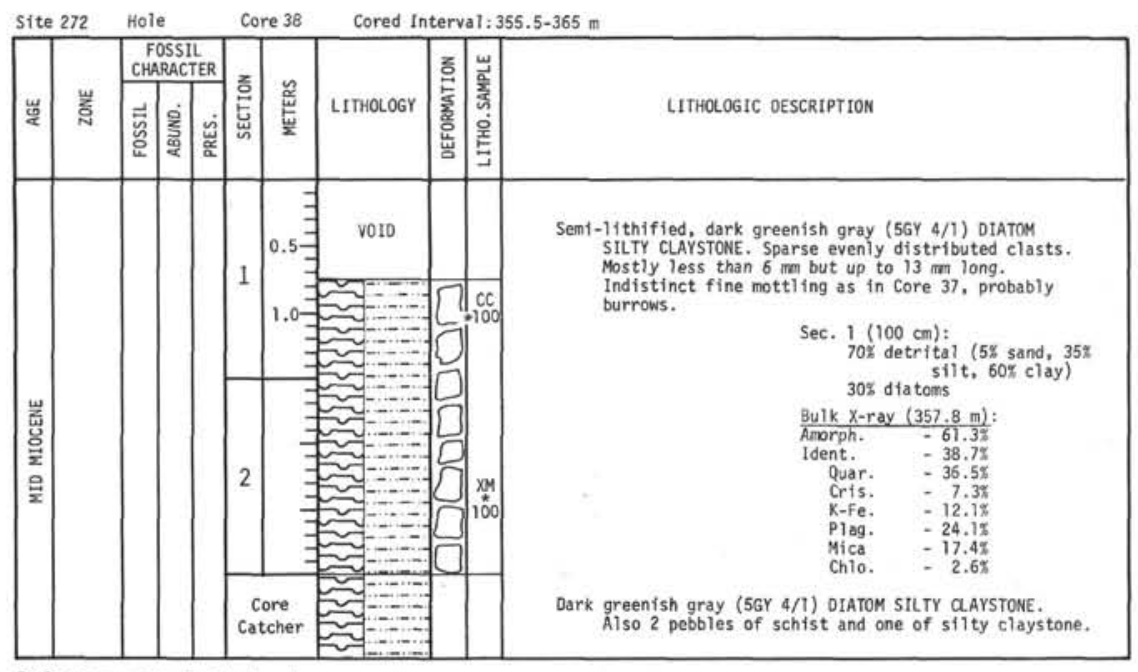



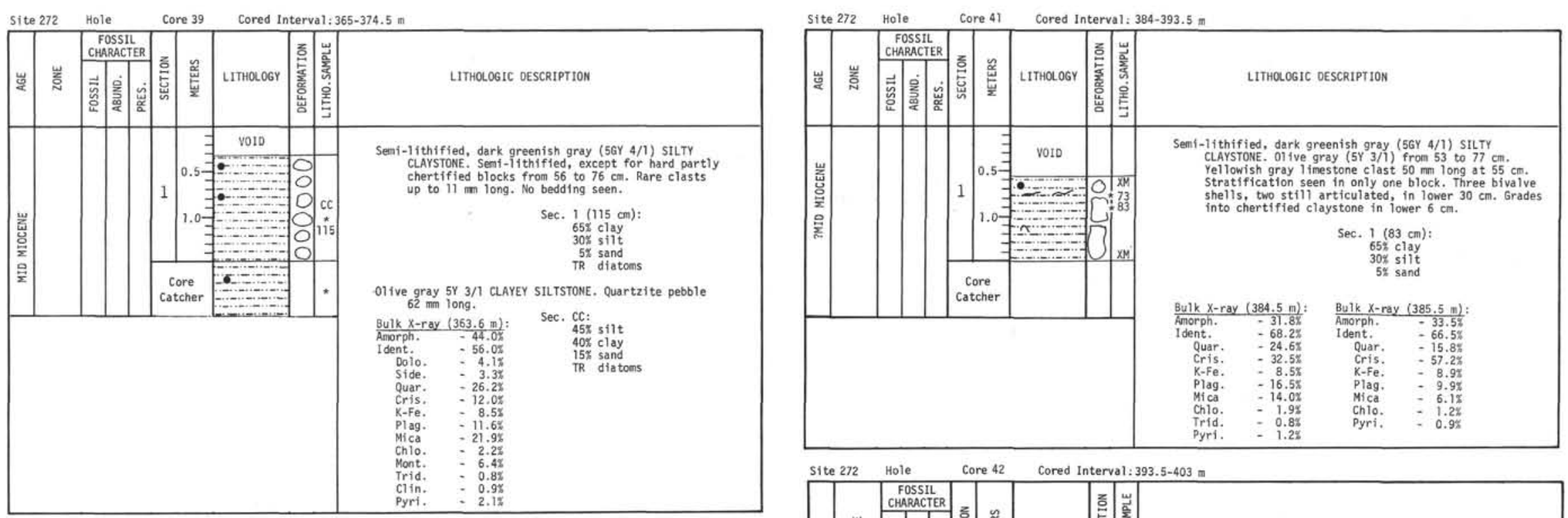

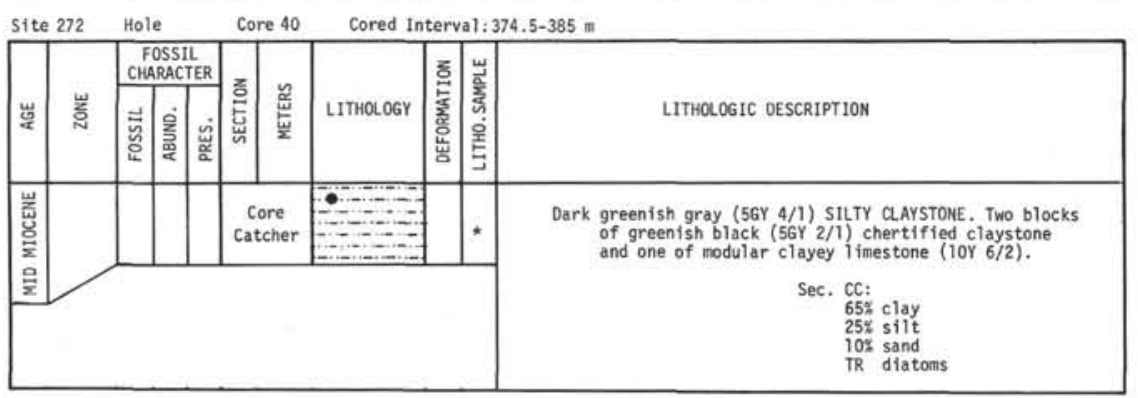

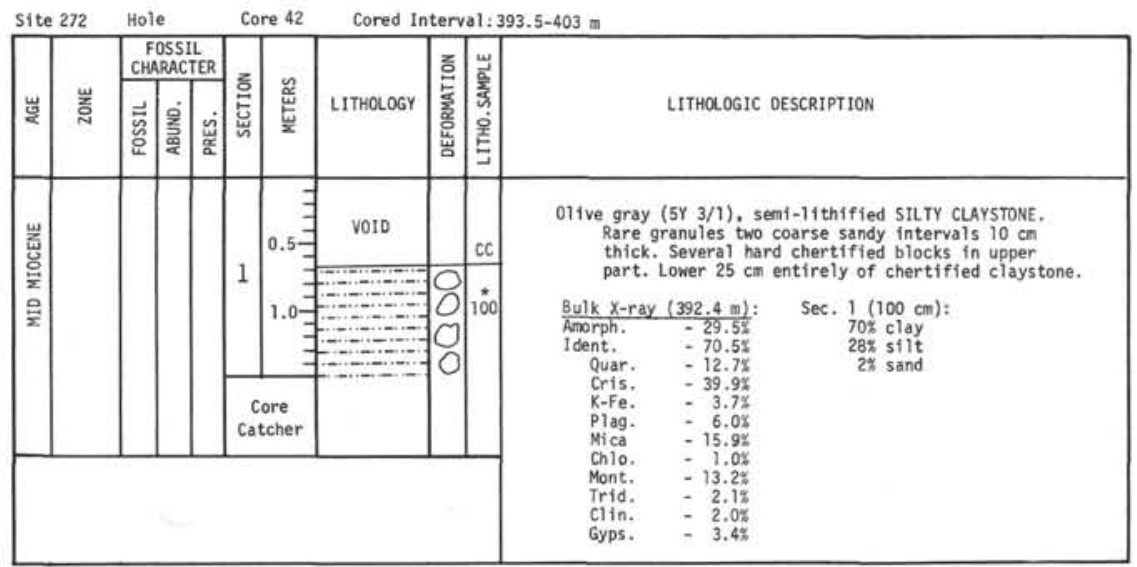

Explanatory notes in Chapter 1 

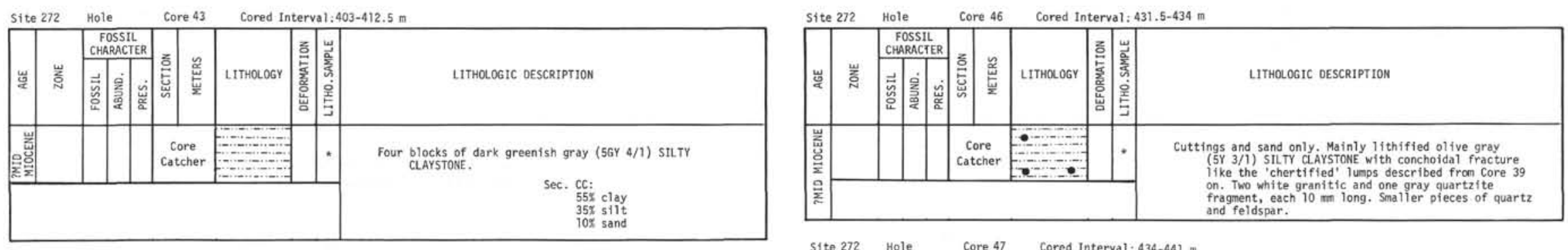

\begin{tabular}{|l|l|l|l|l|l|l|}
\hline Site 272 & Hole \\
\hline
\end{tabular}

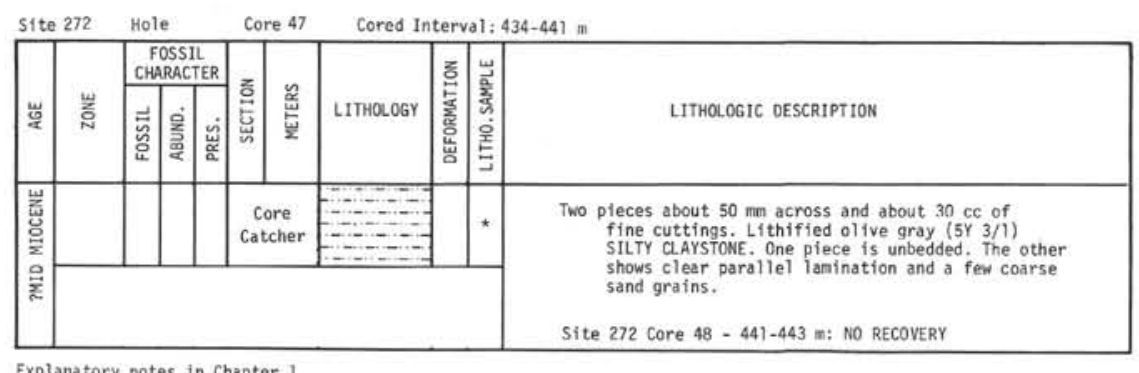

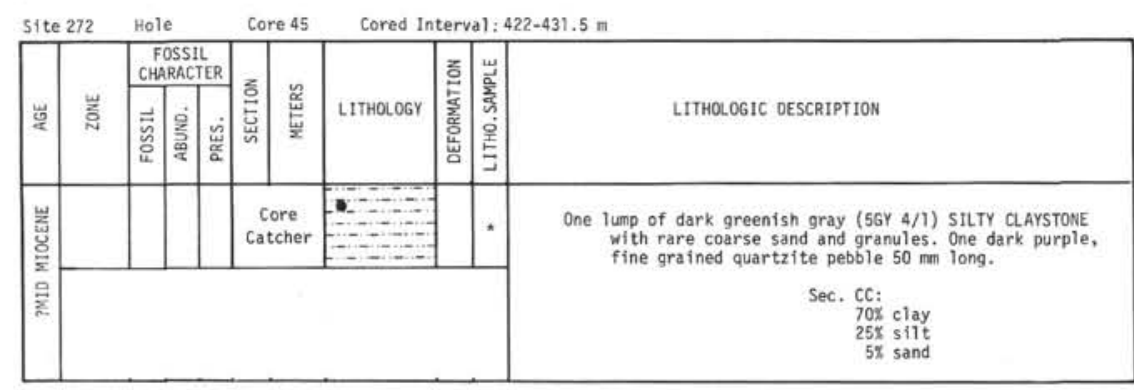


SITES 270, 271, 272

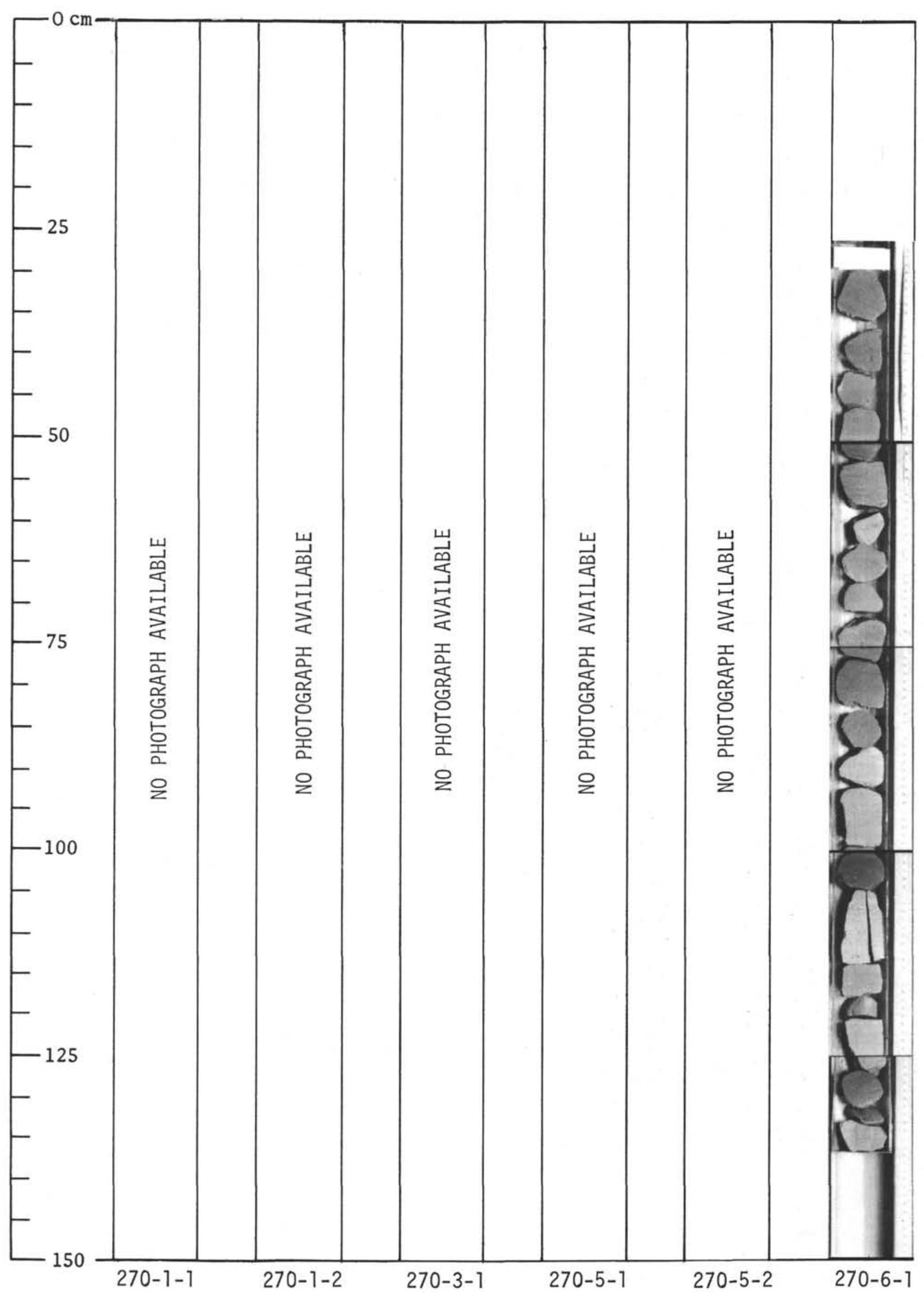


SITES 270, 271, 272

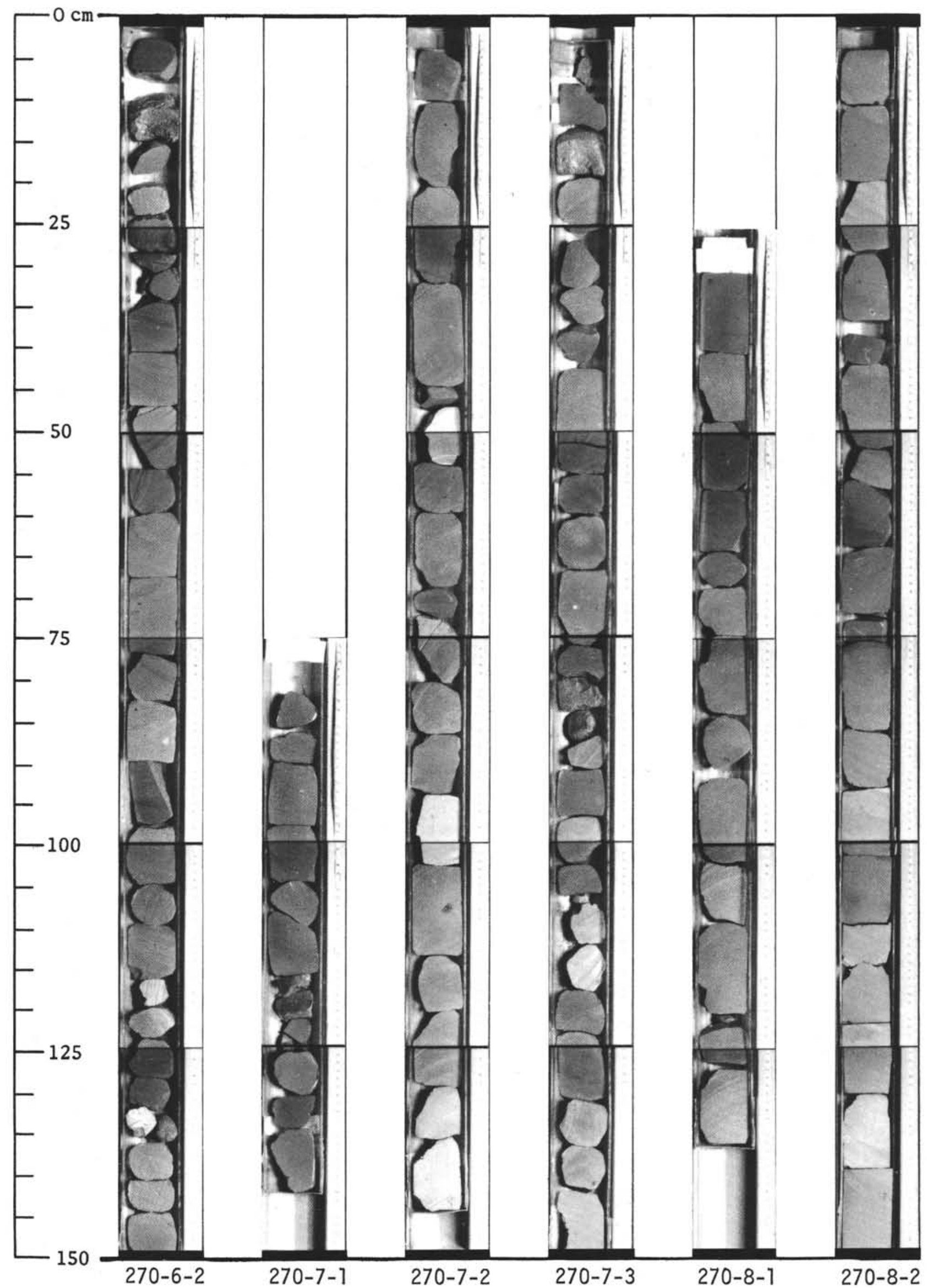


SITES 270, 271, 272

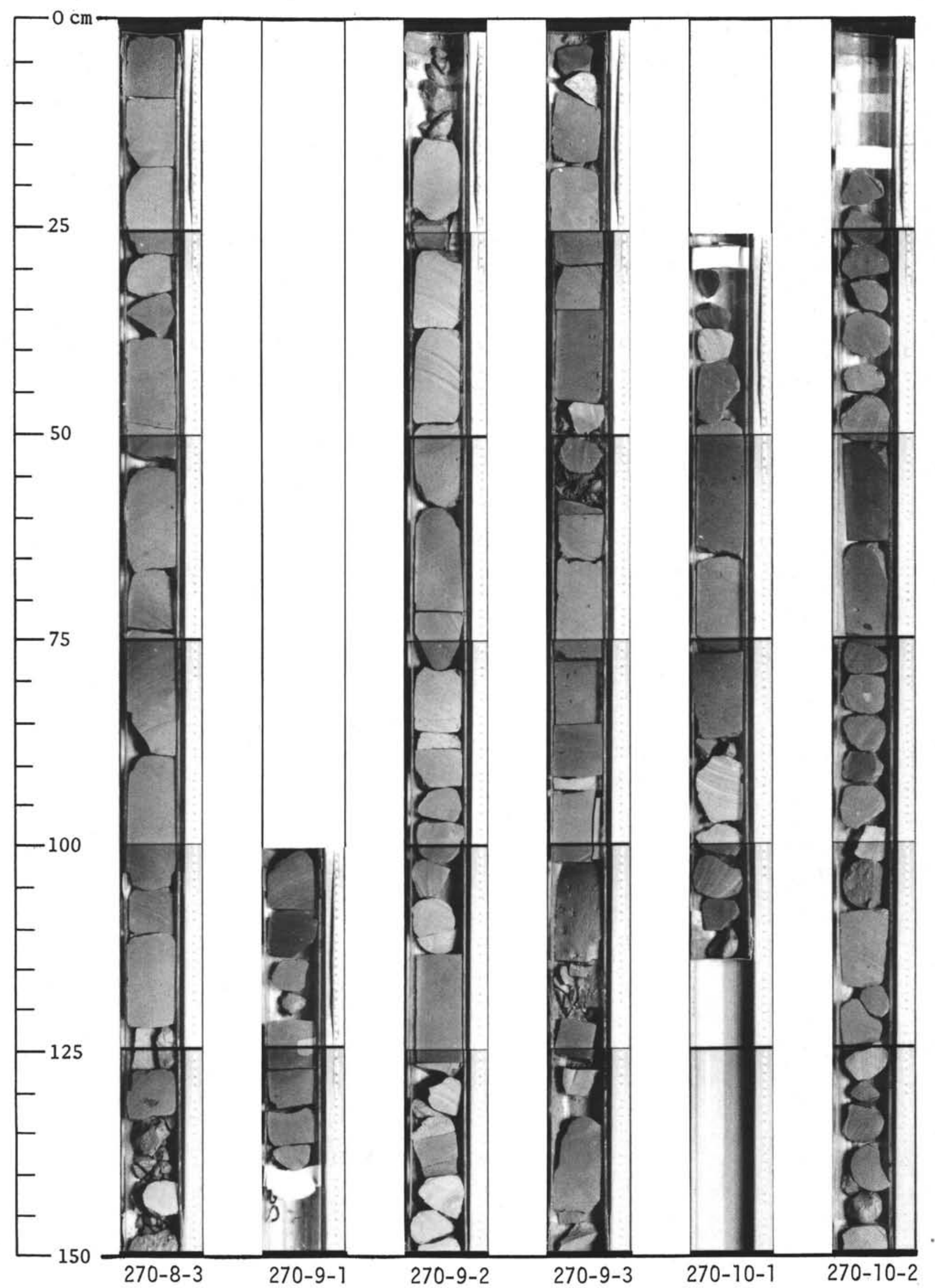




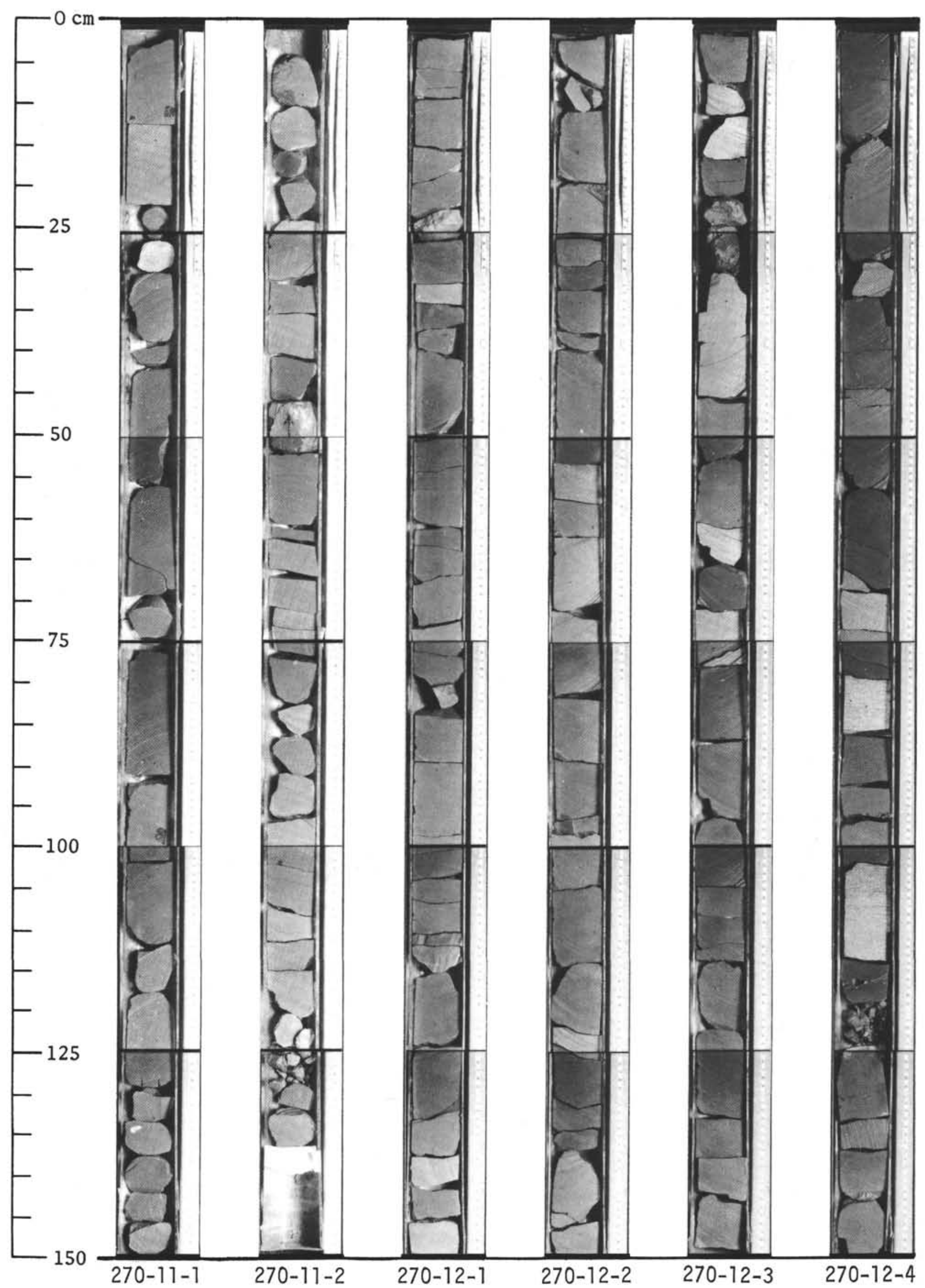


SITES 270, 271, 272

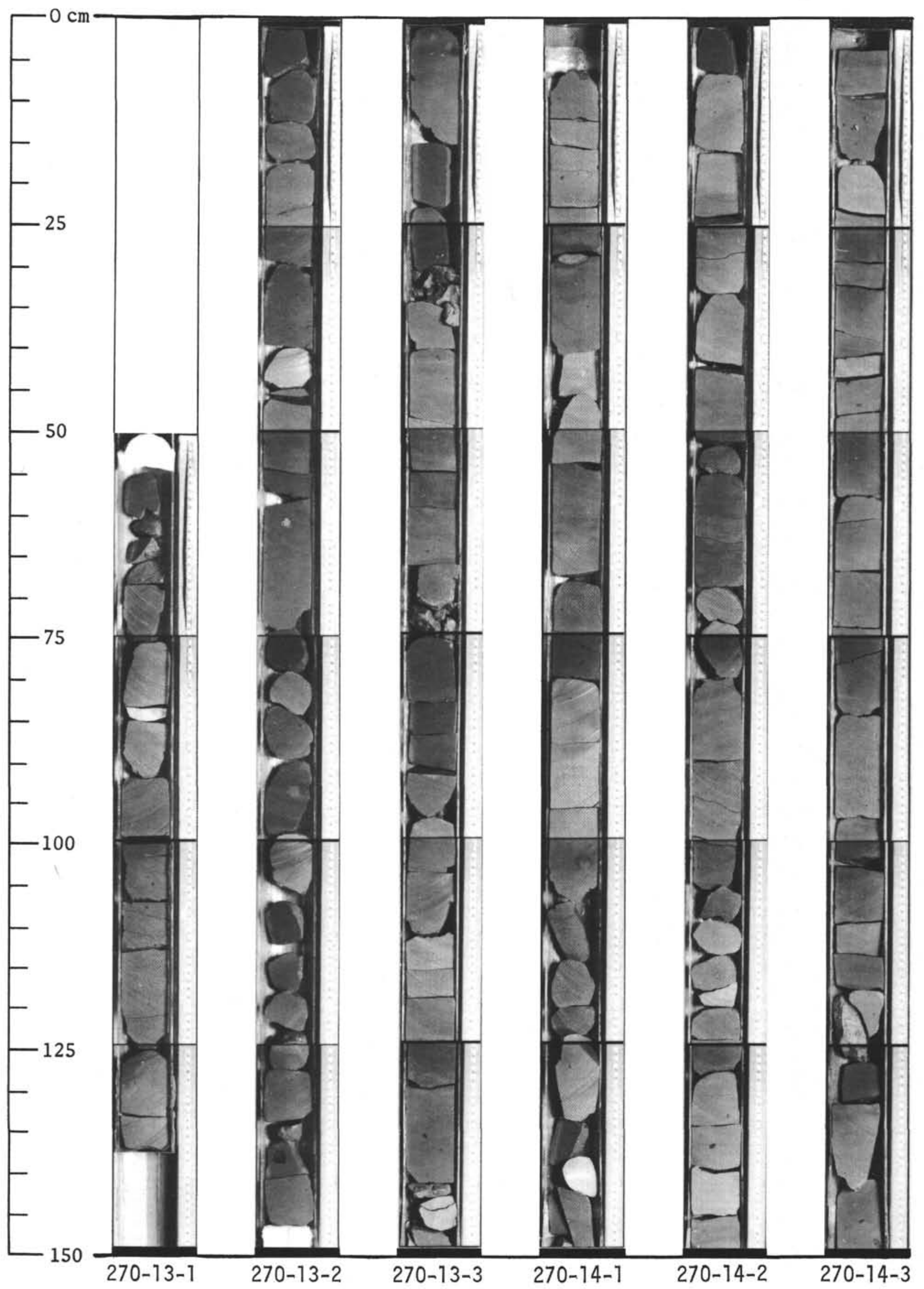




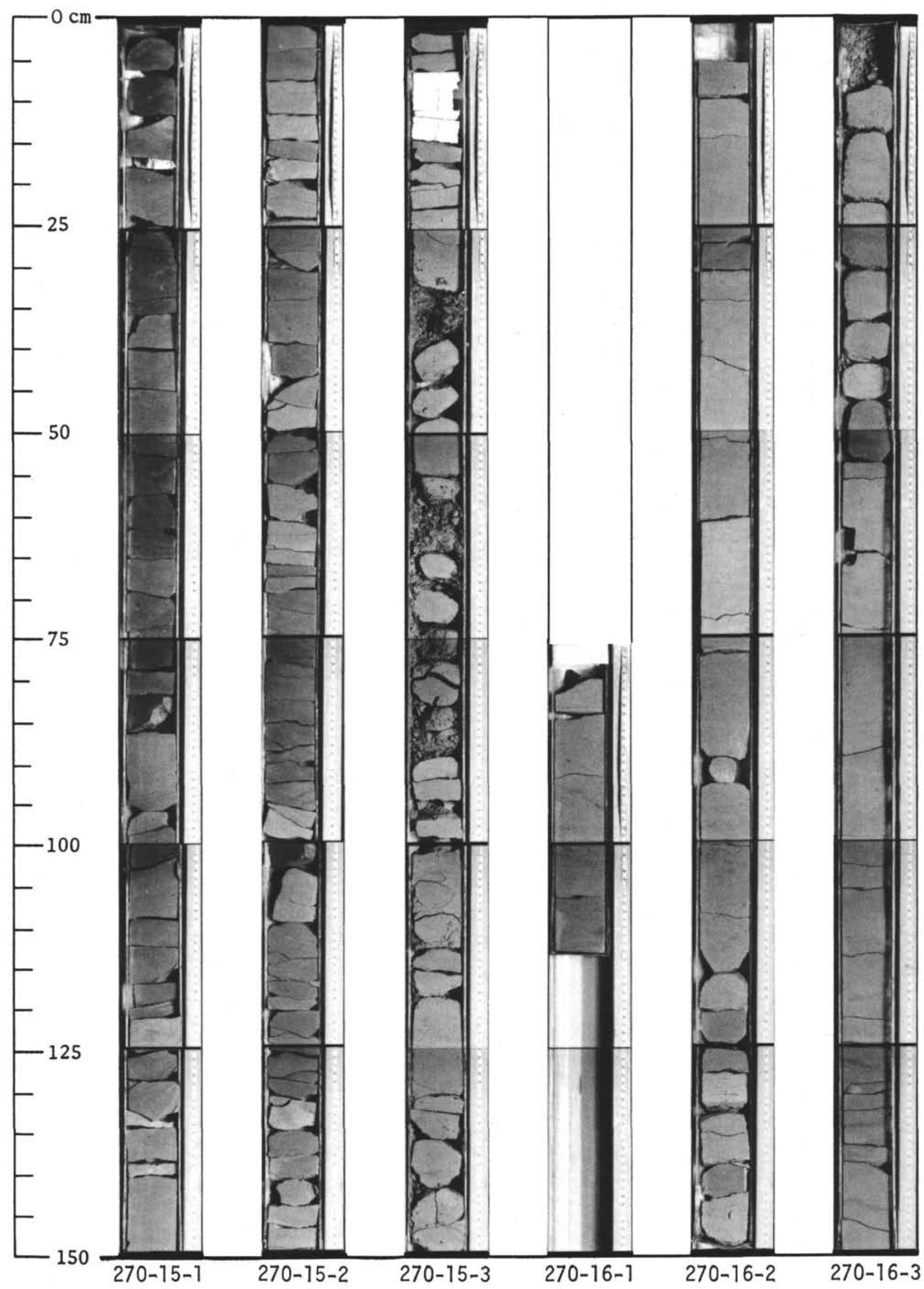




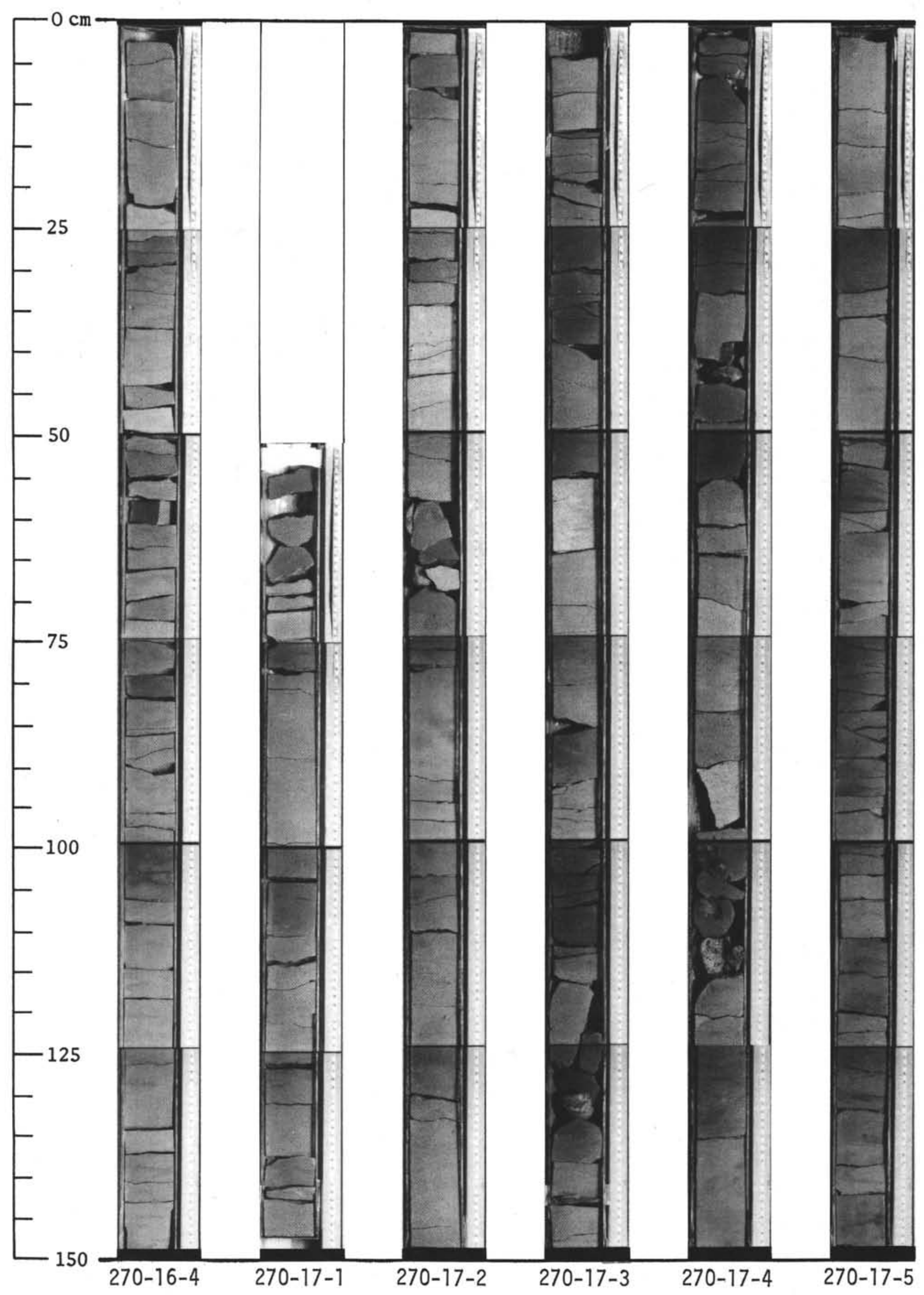




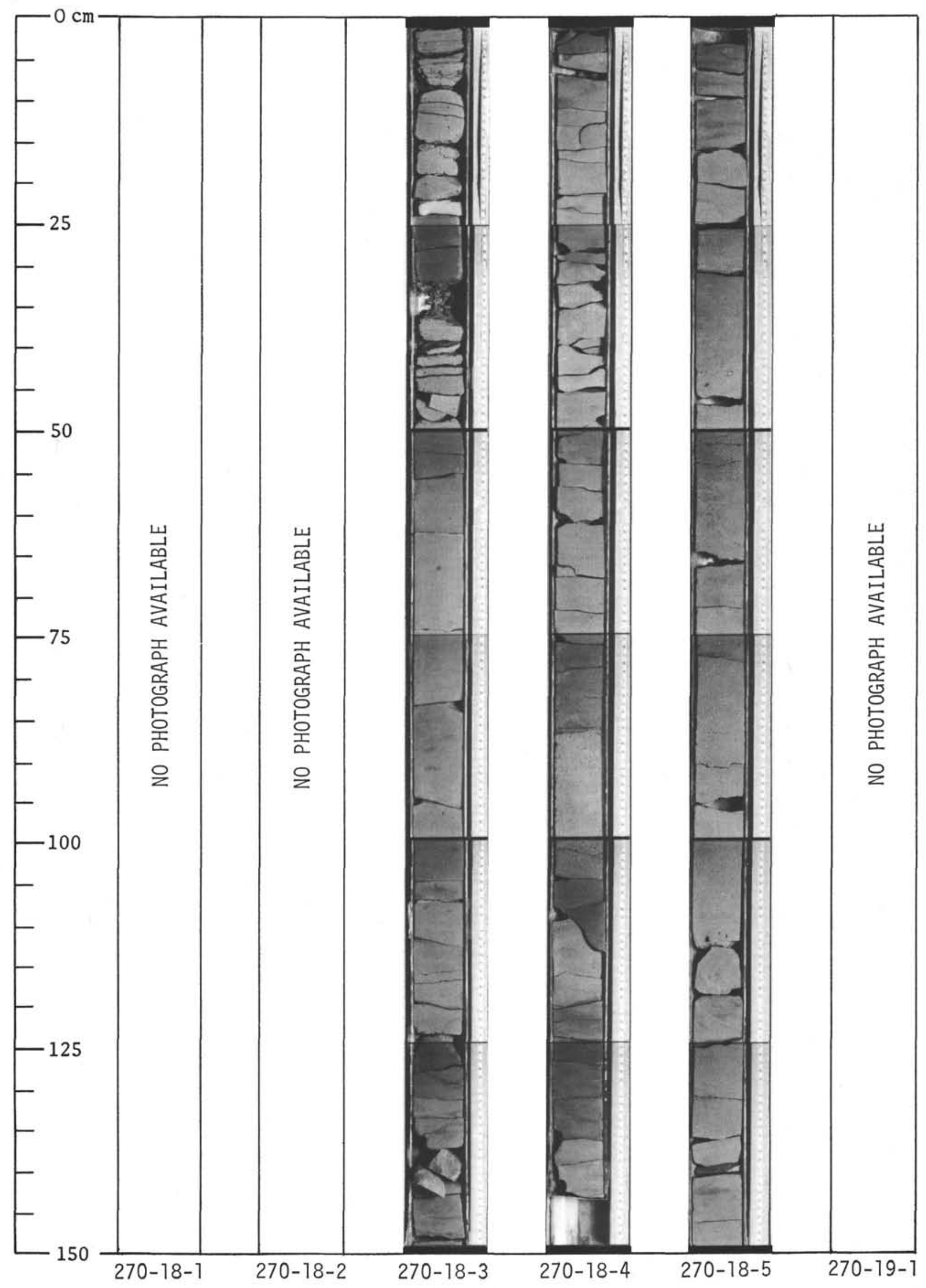




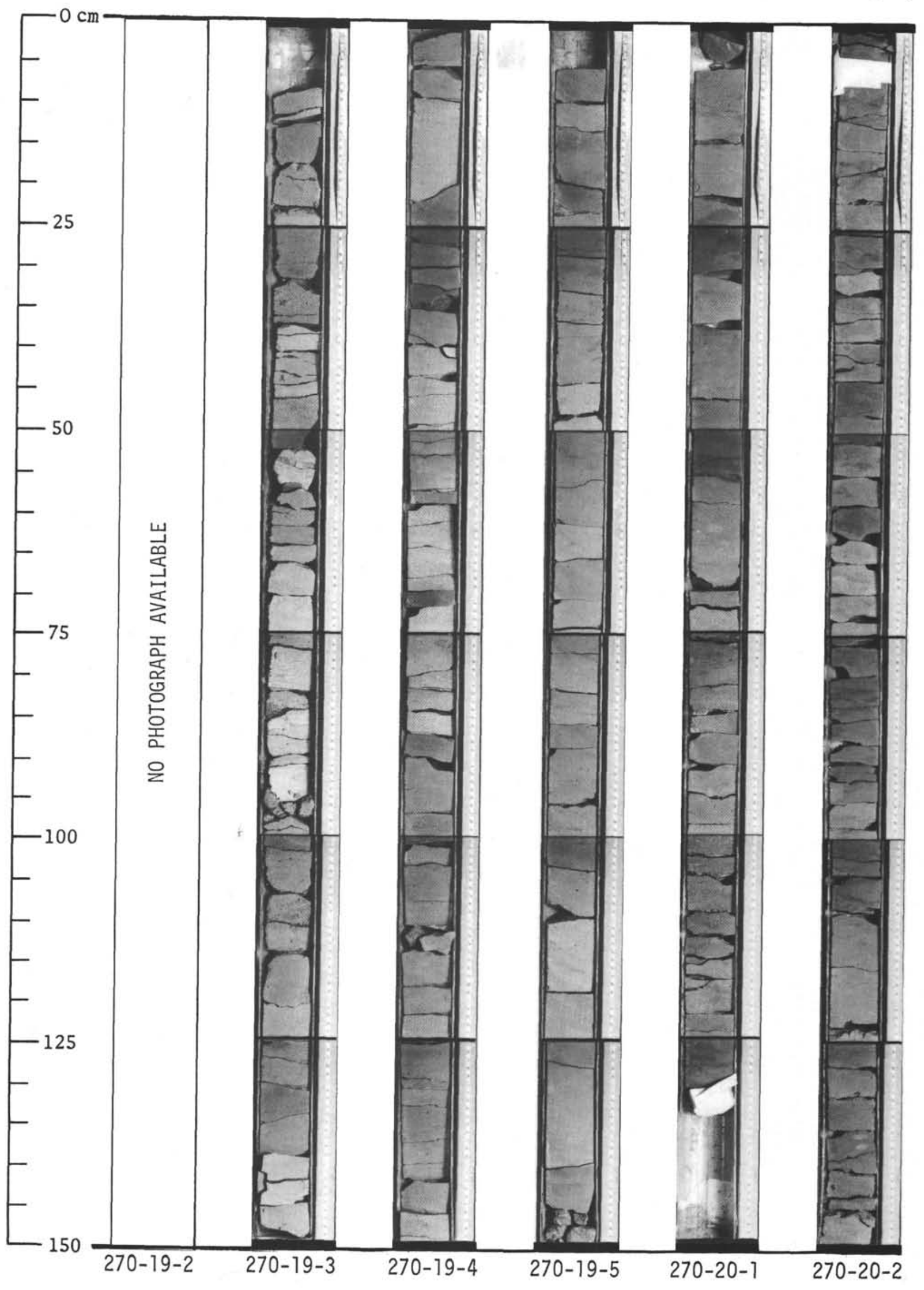




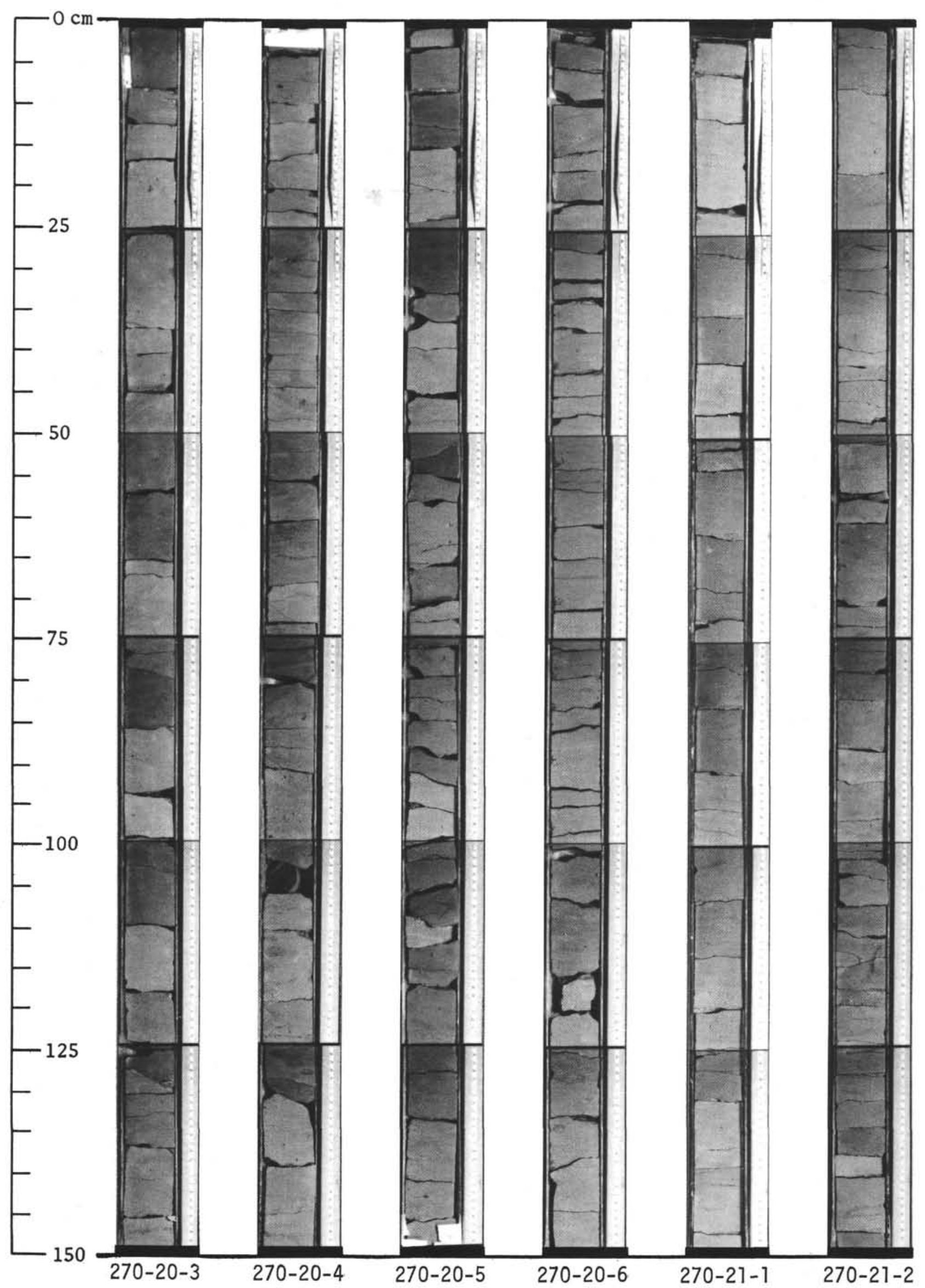


SITES 270, 271, 272

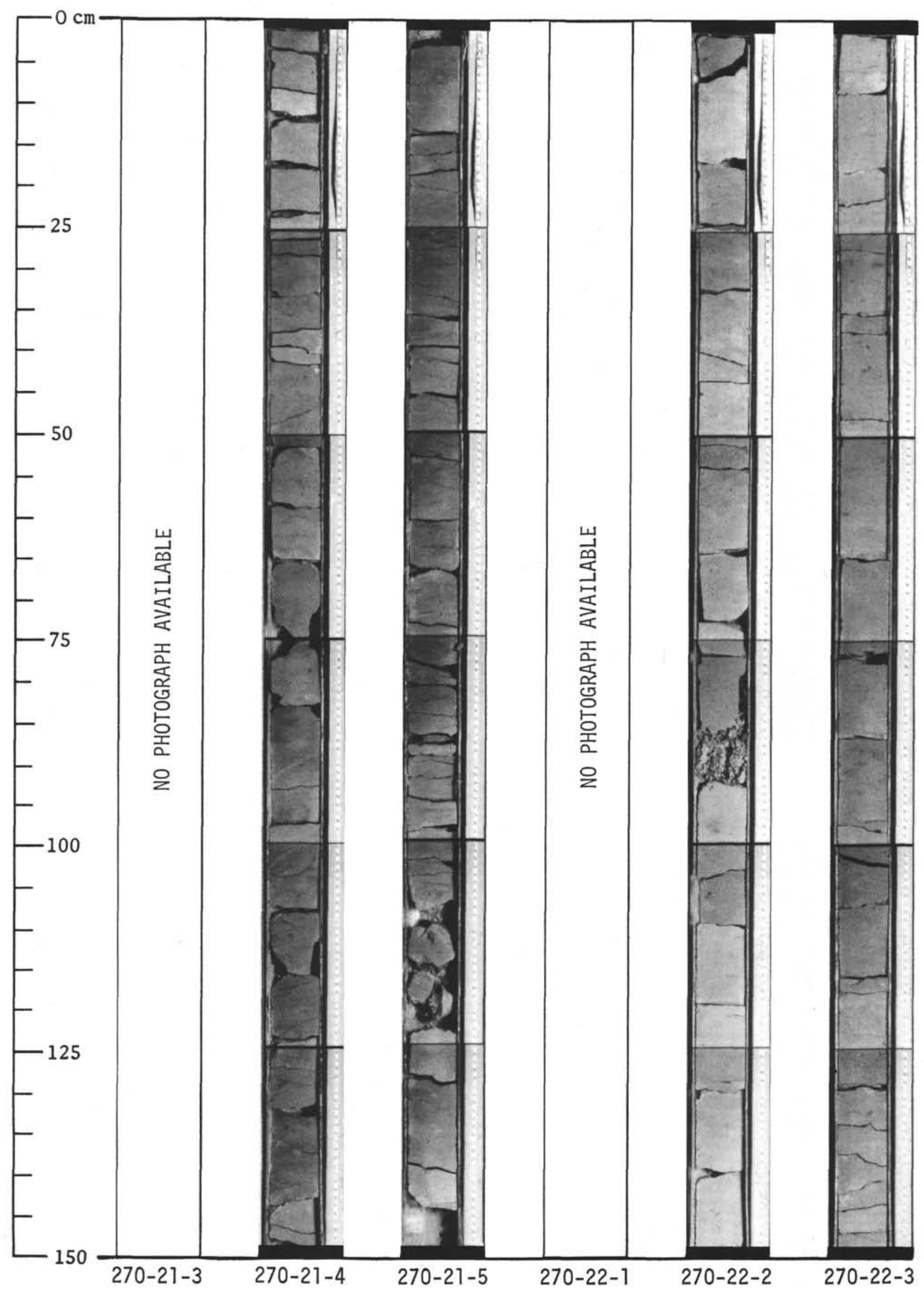




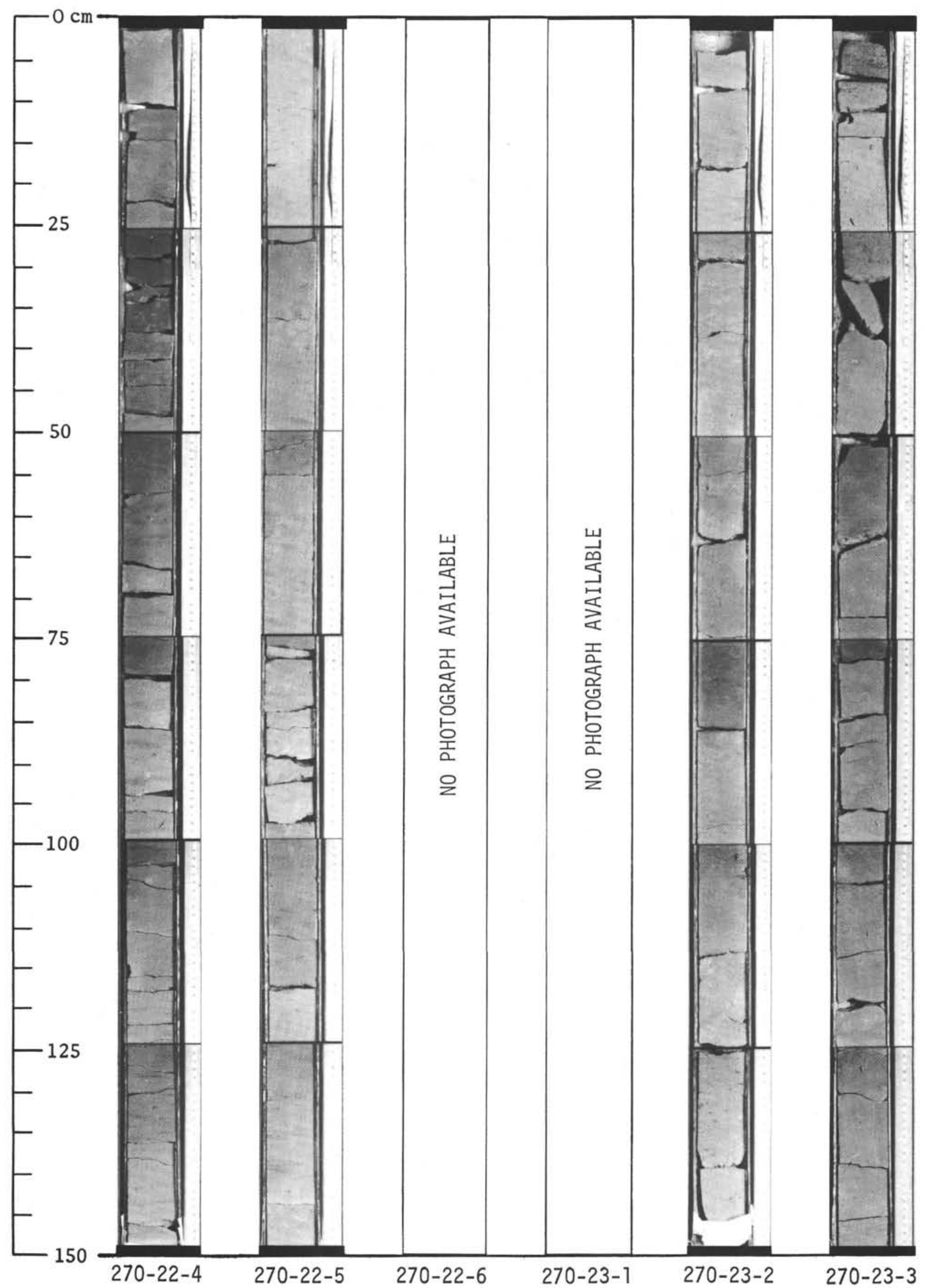




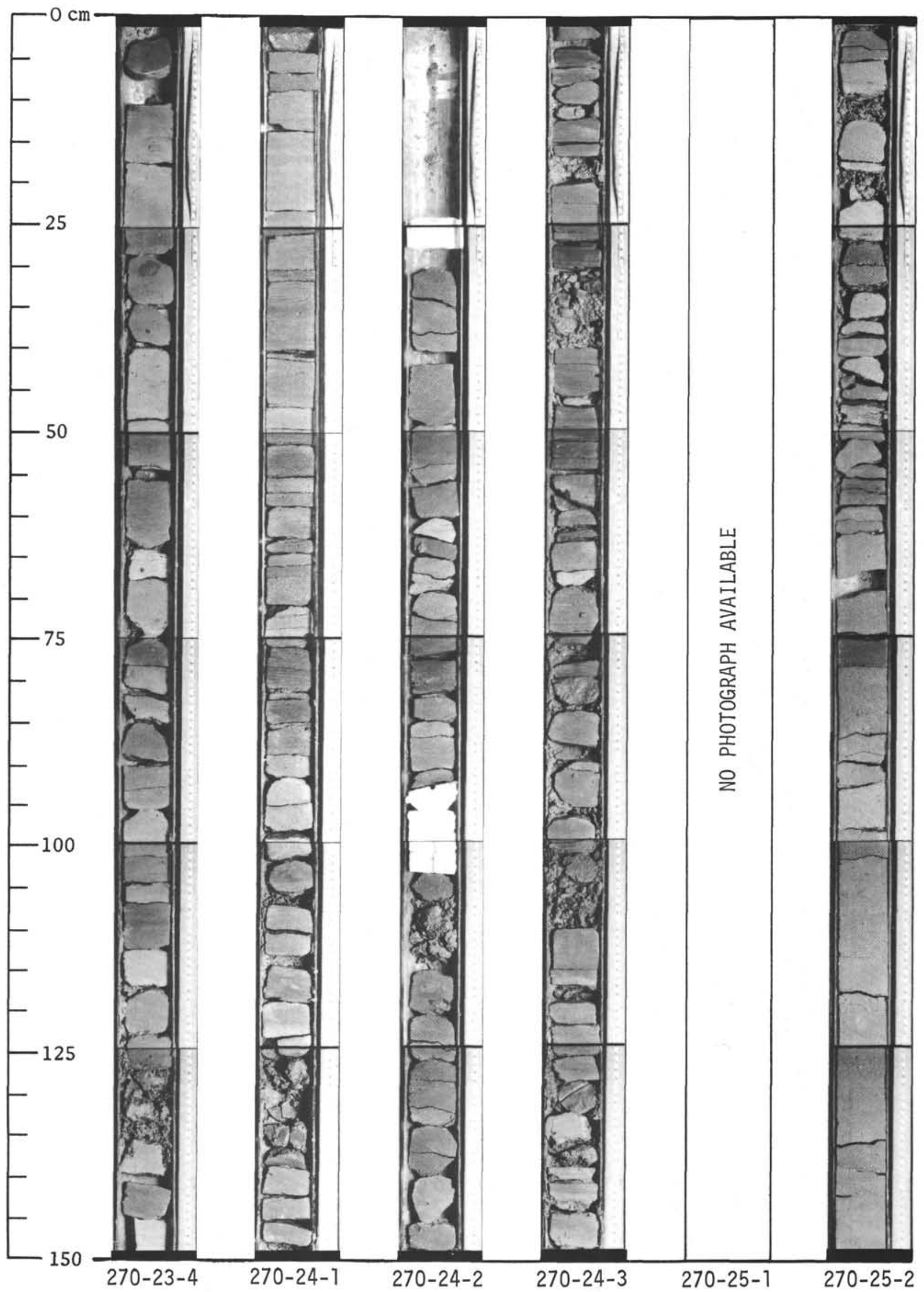




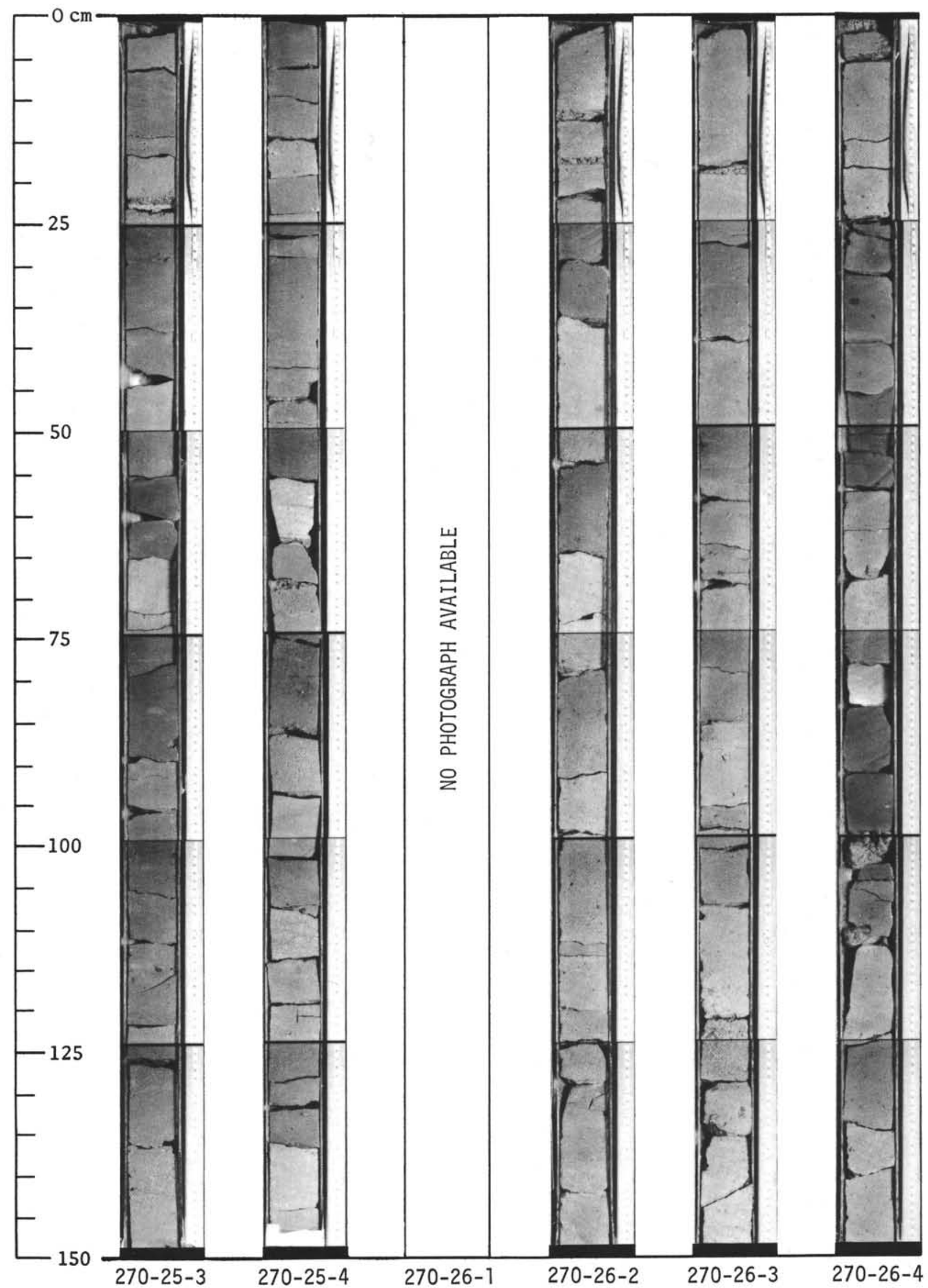




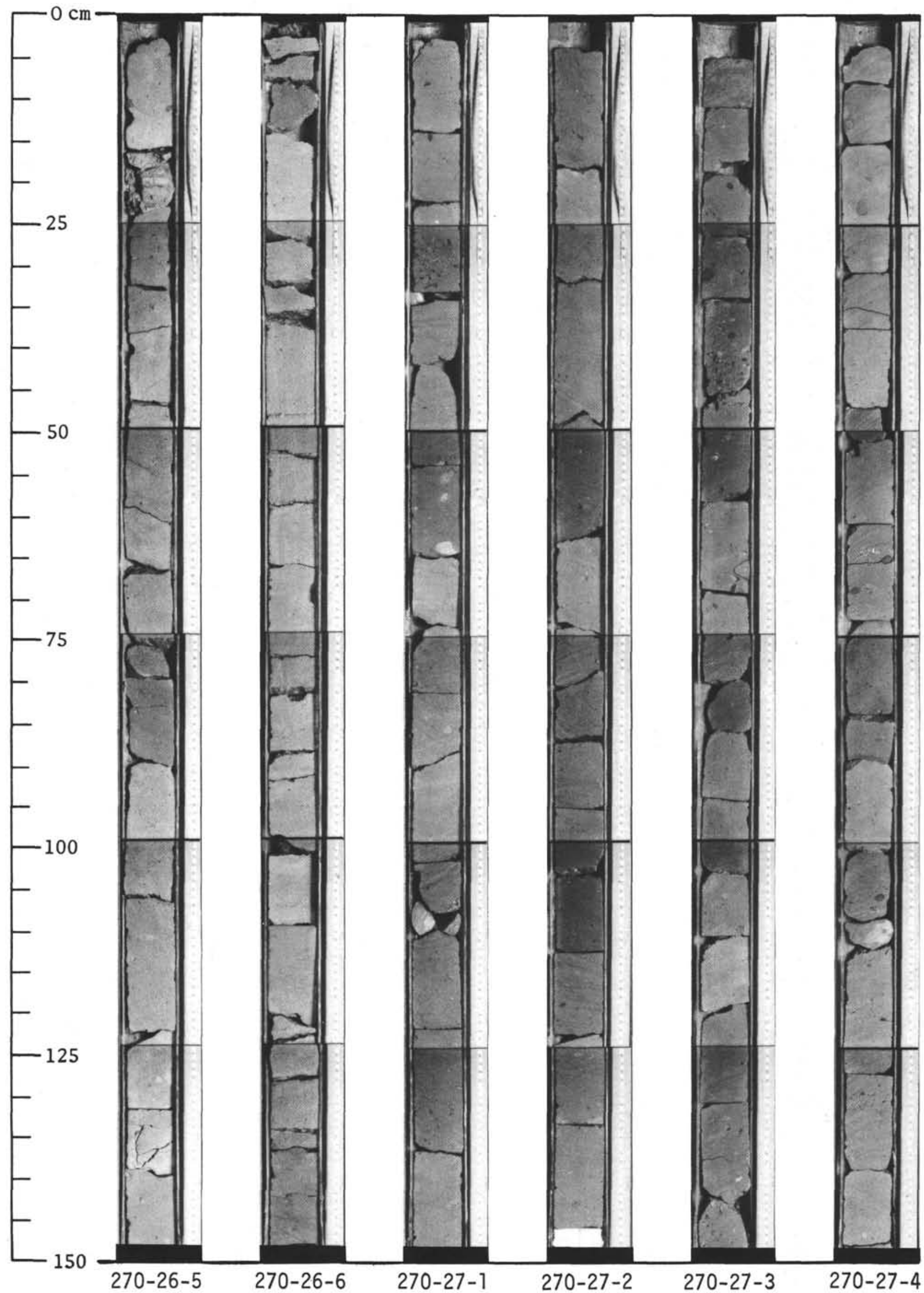




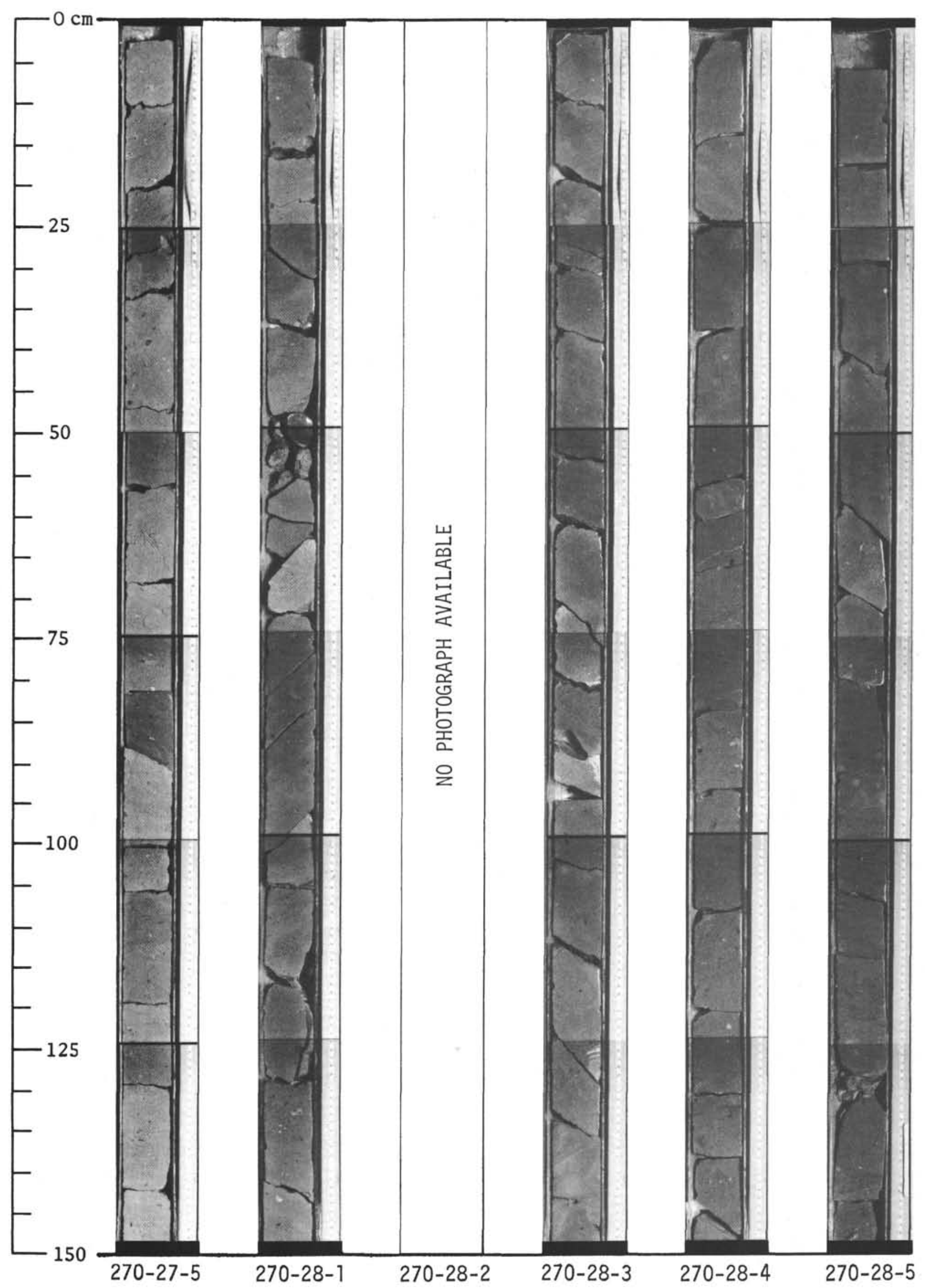




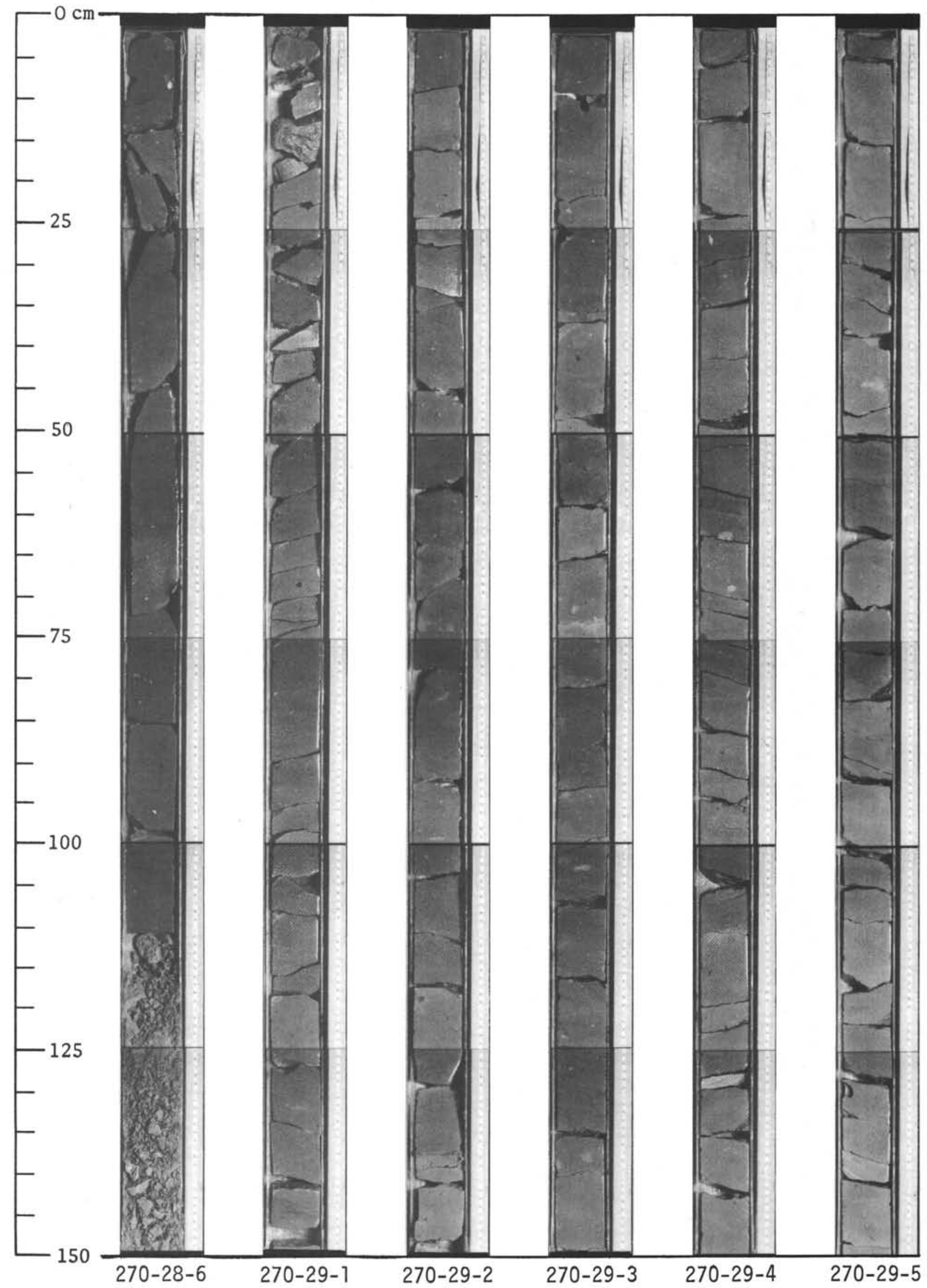




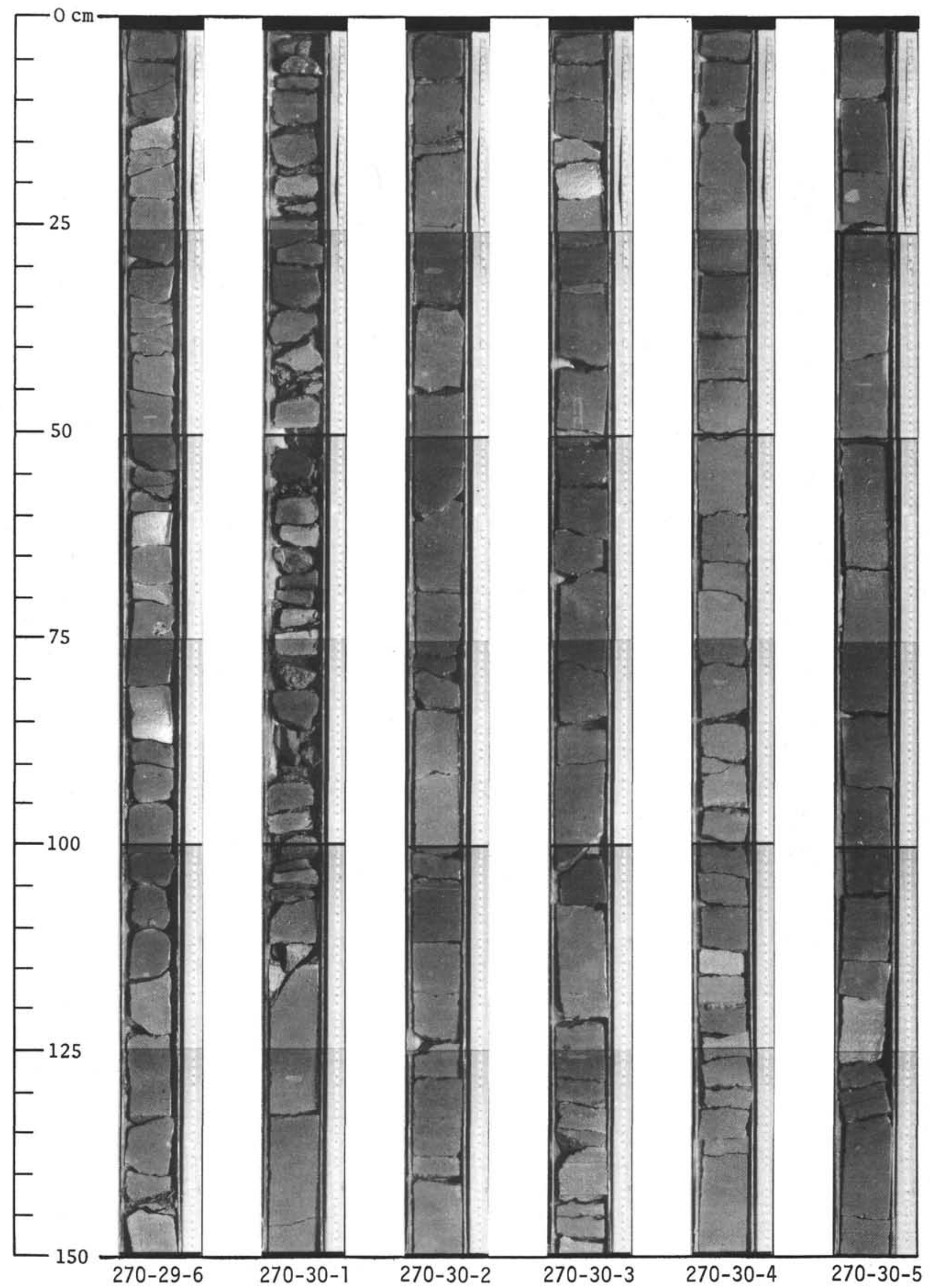


SITES 270, 271, 272

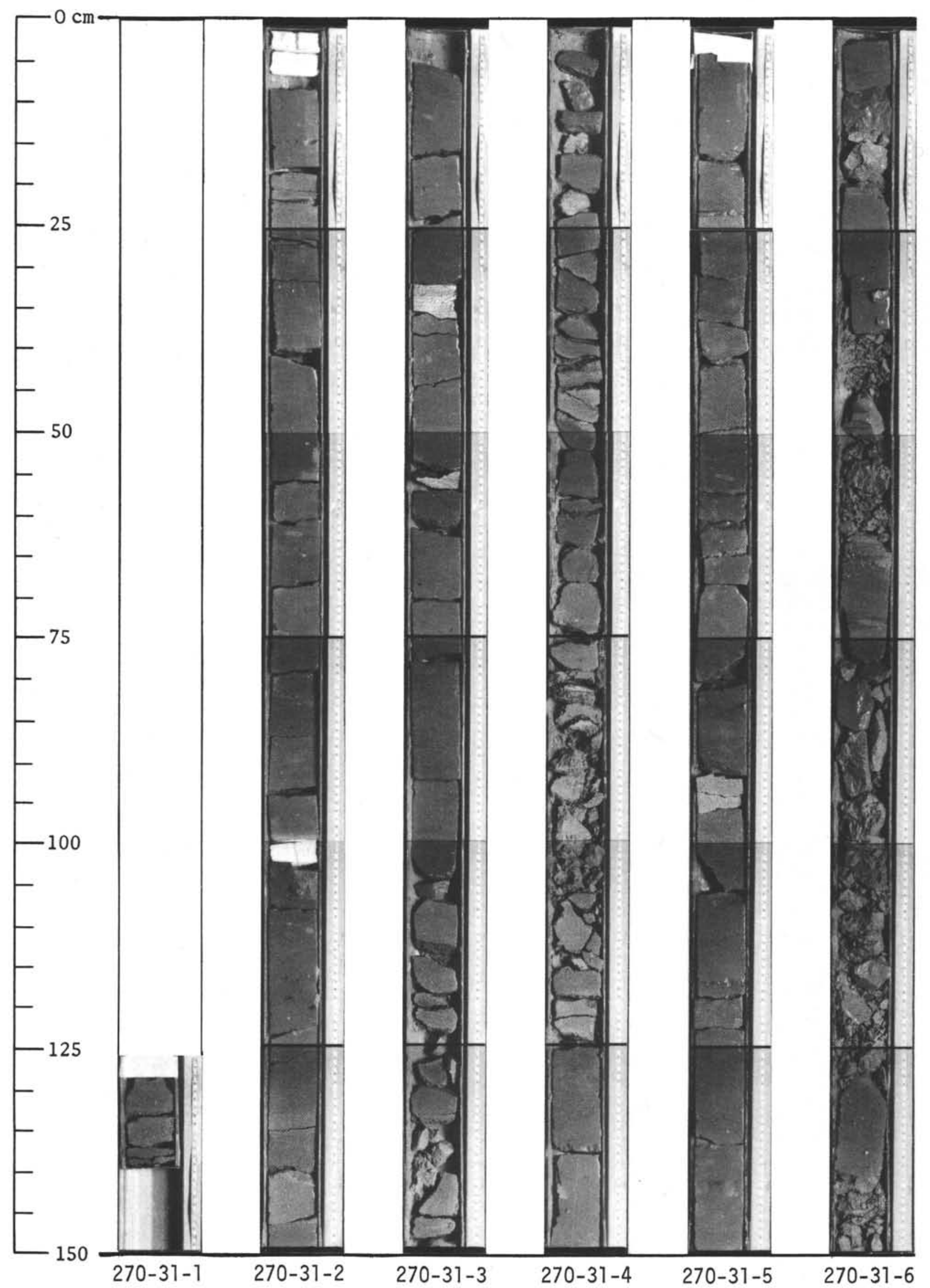




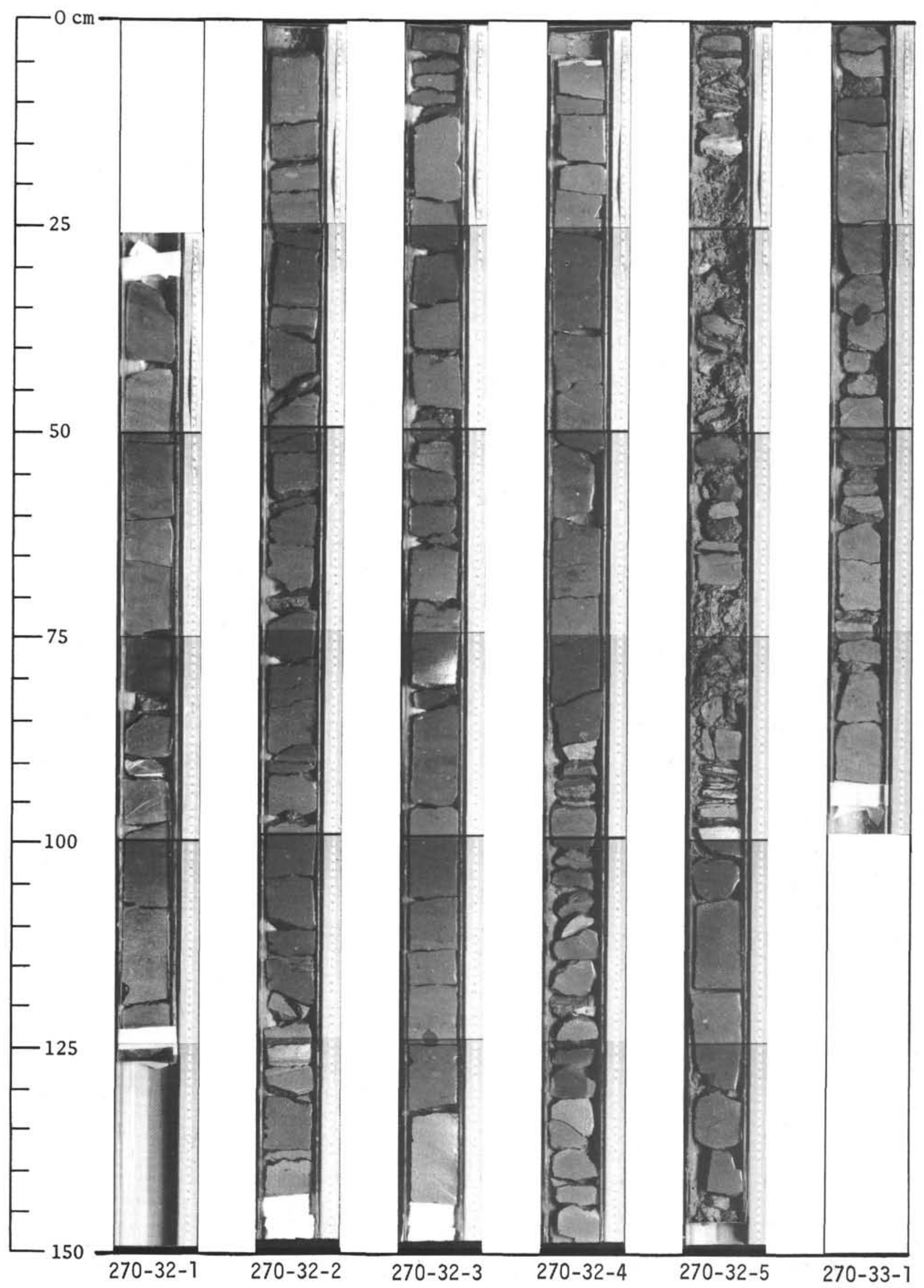


SITES 270, 271, 272

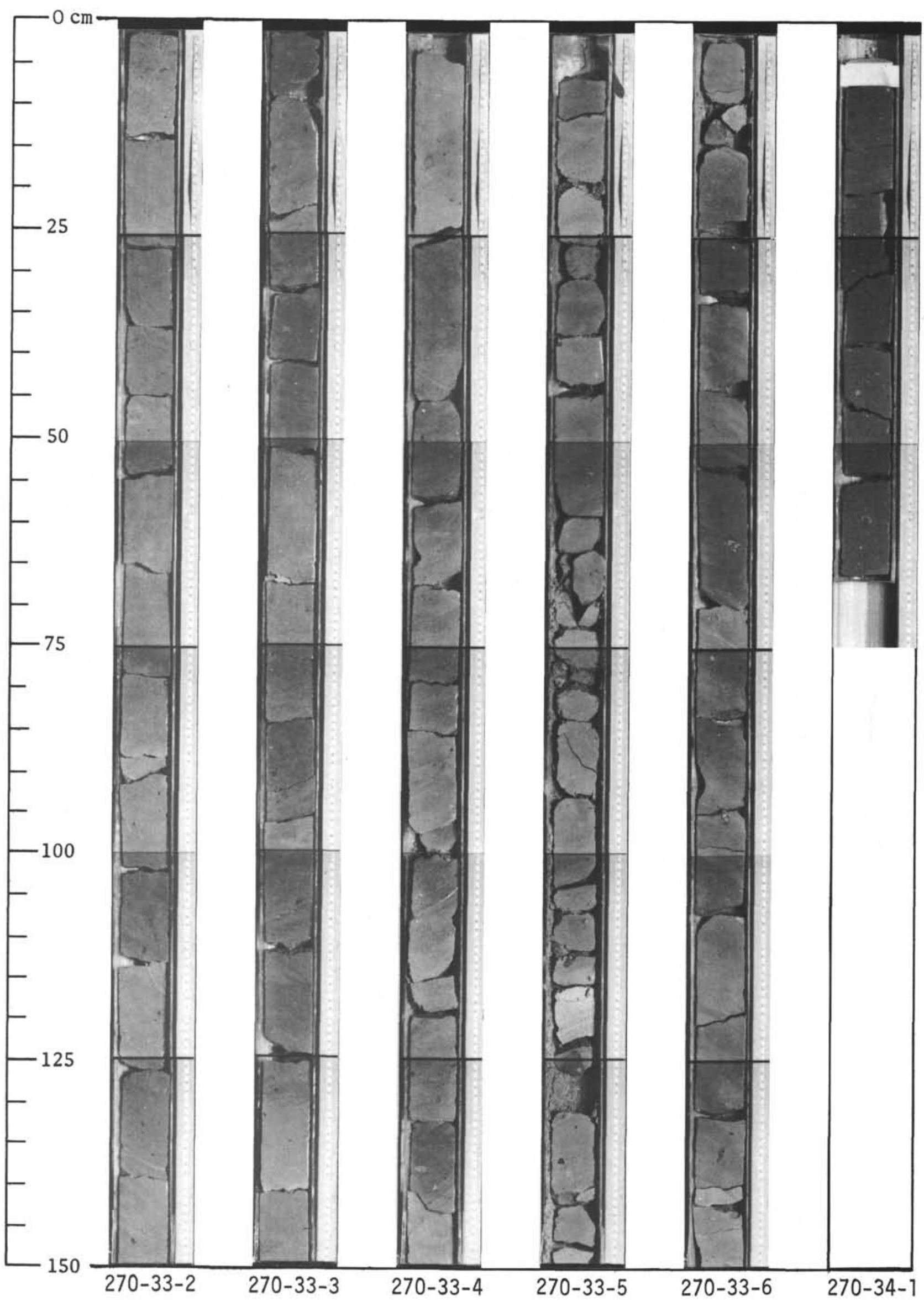




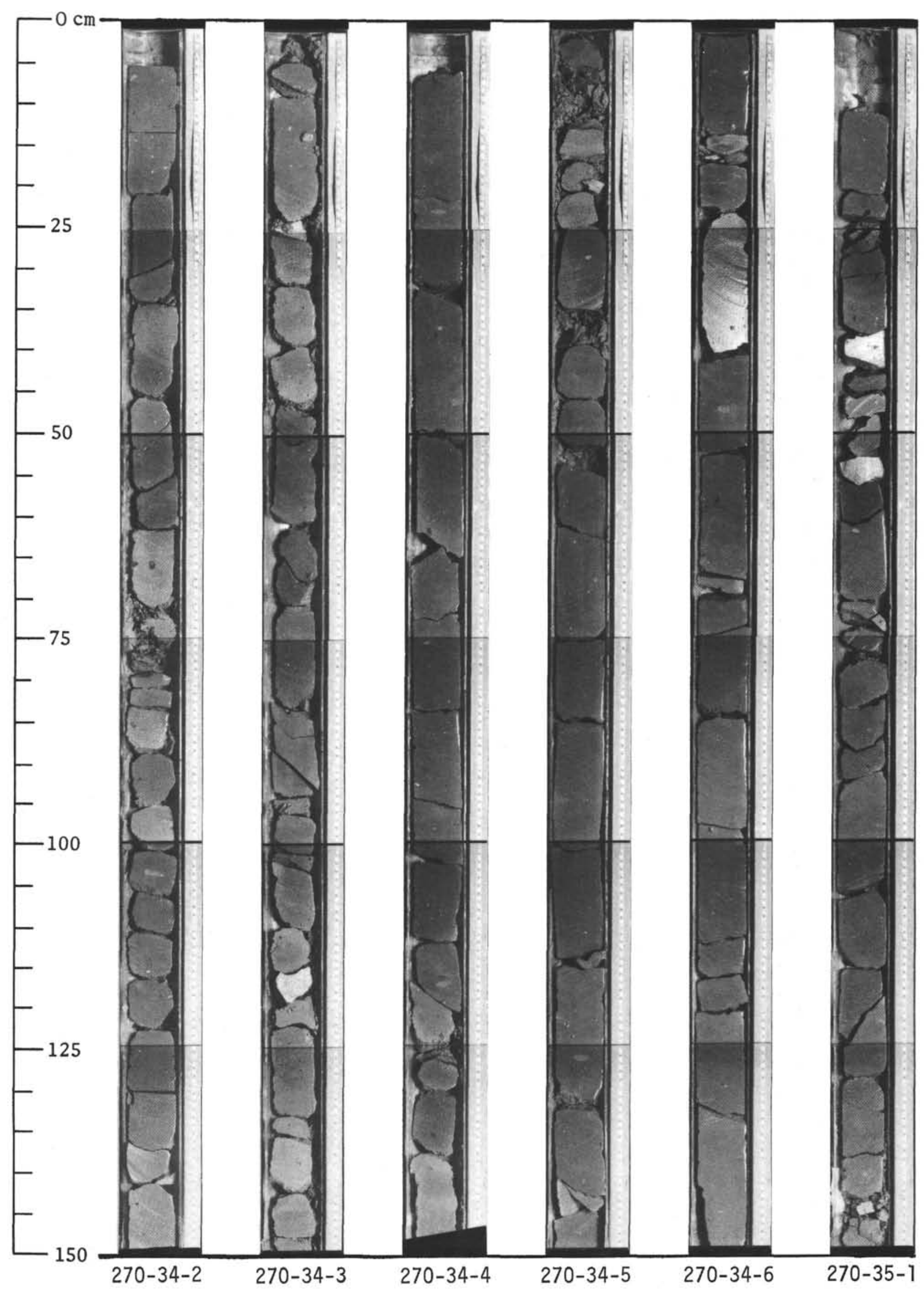




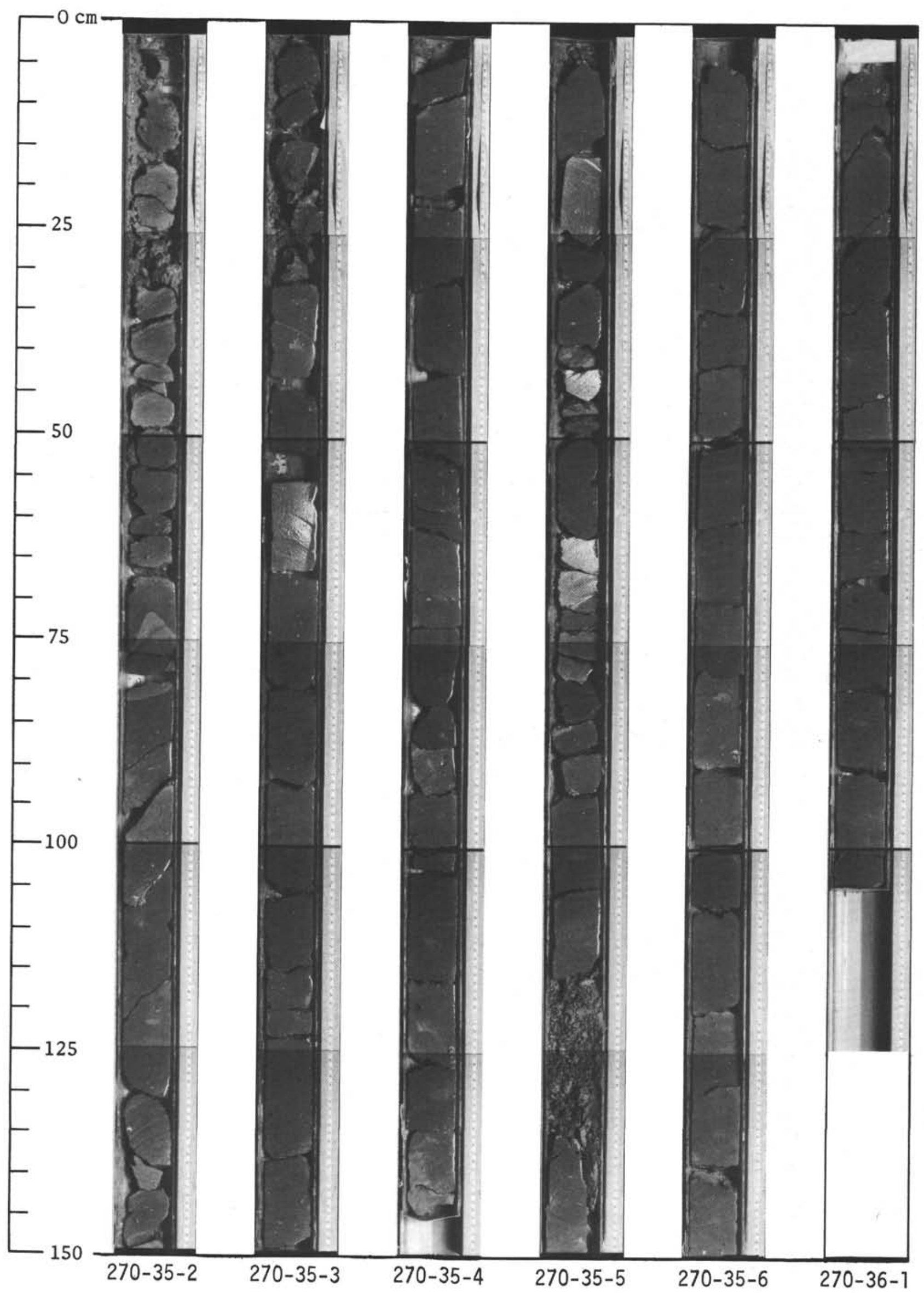




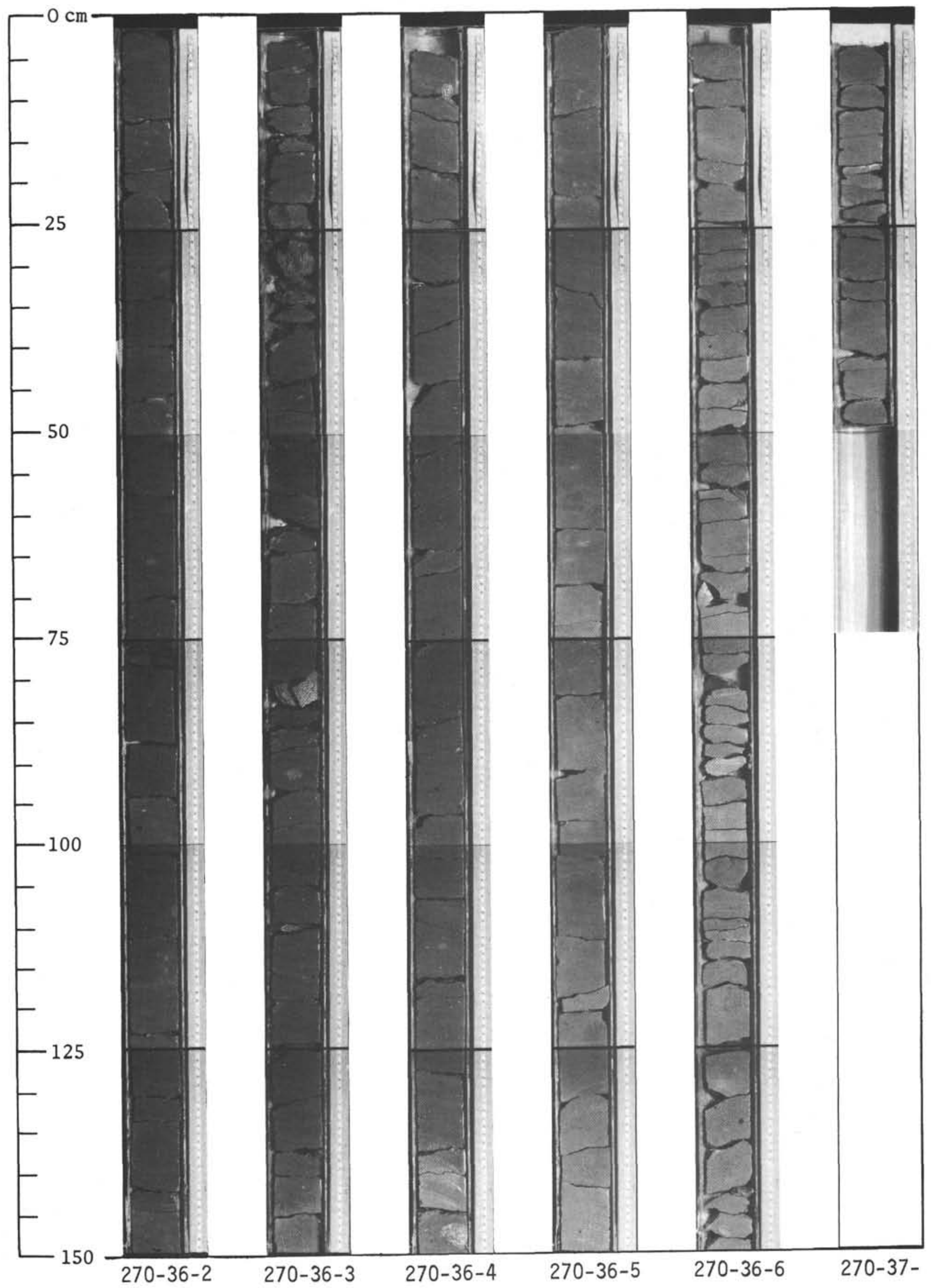


SITES 270, 271, 272

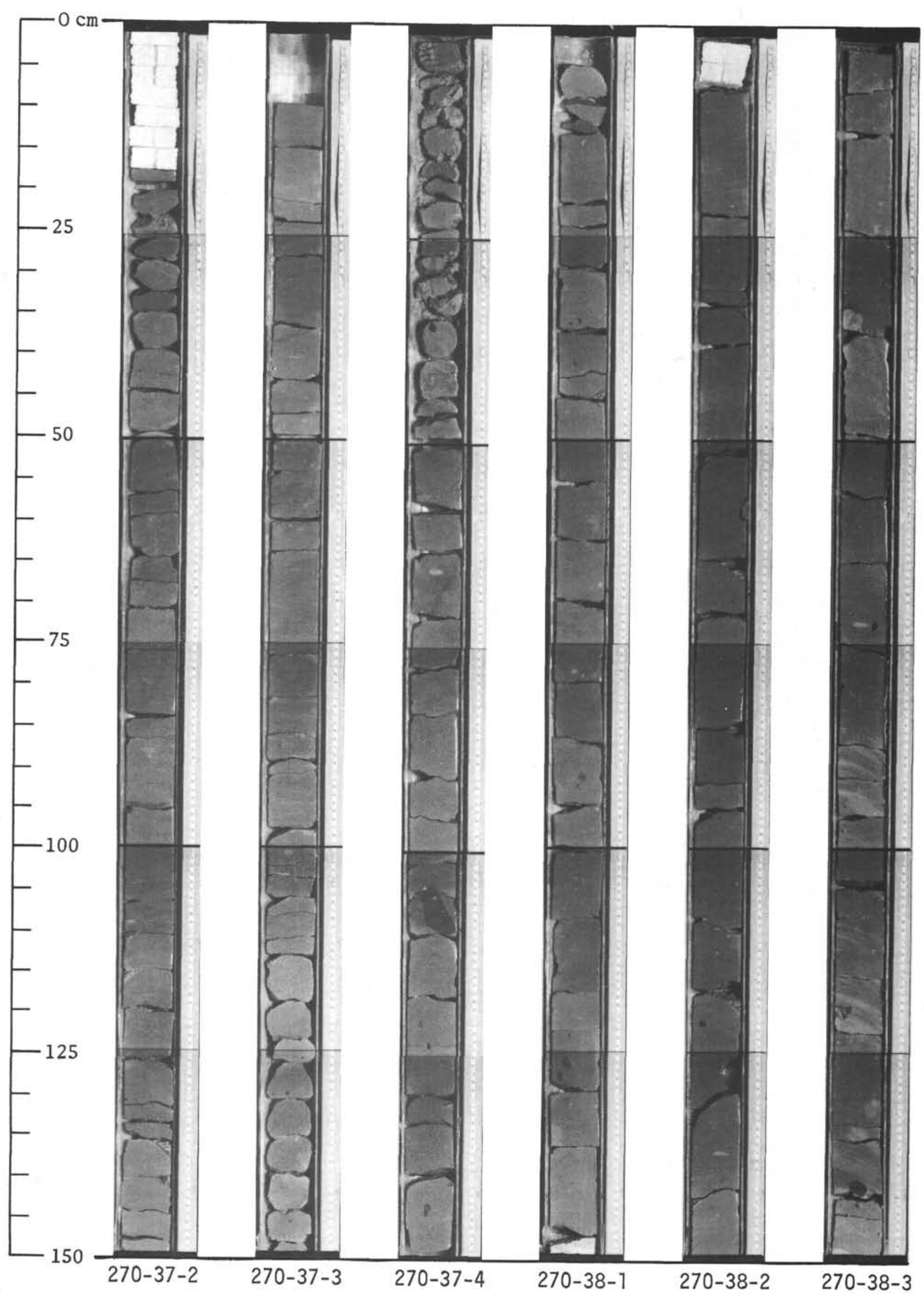




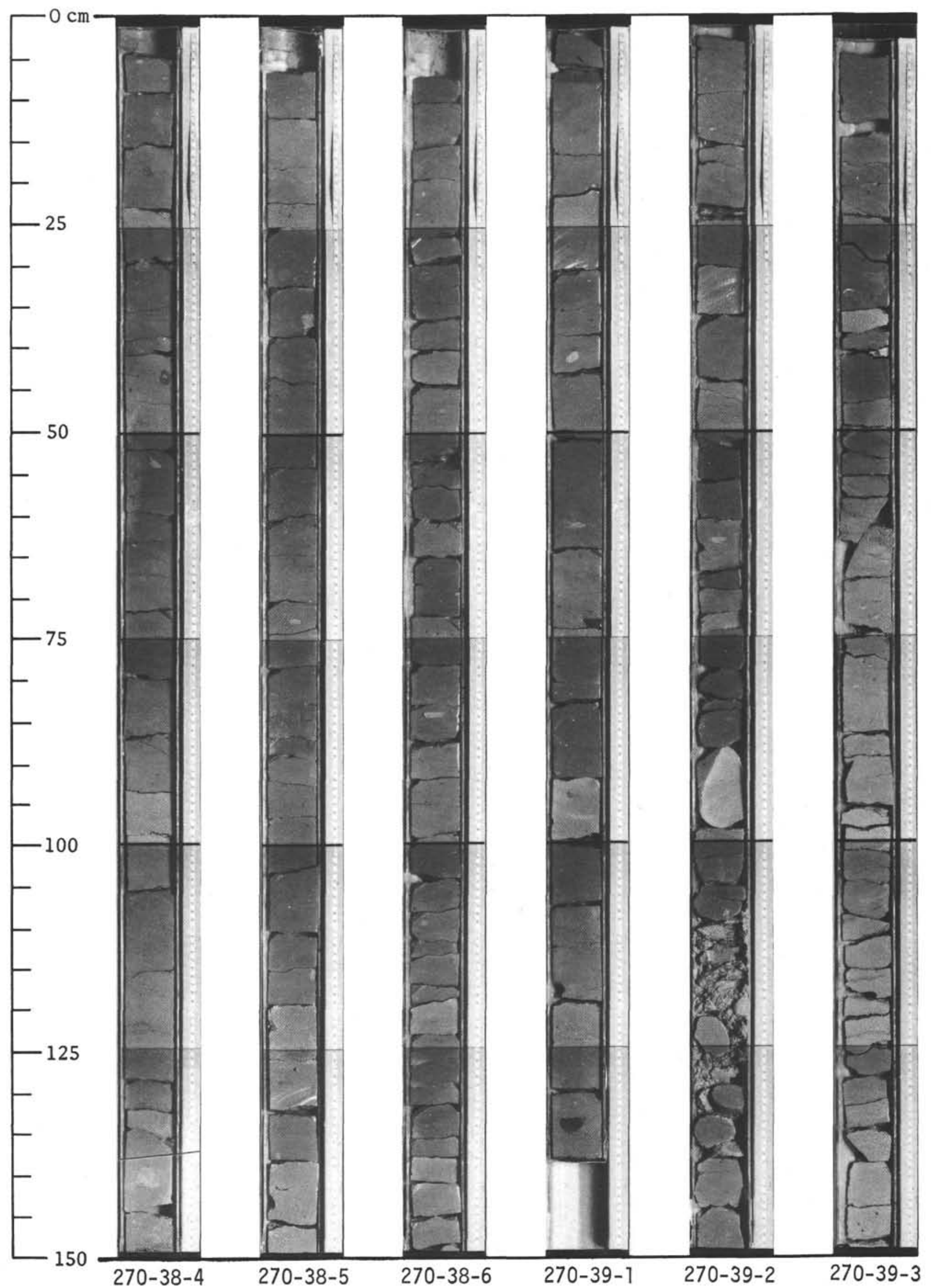


SITES 270, 271, 272

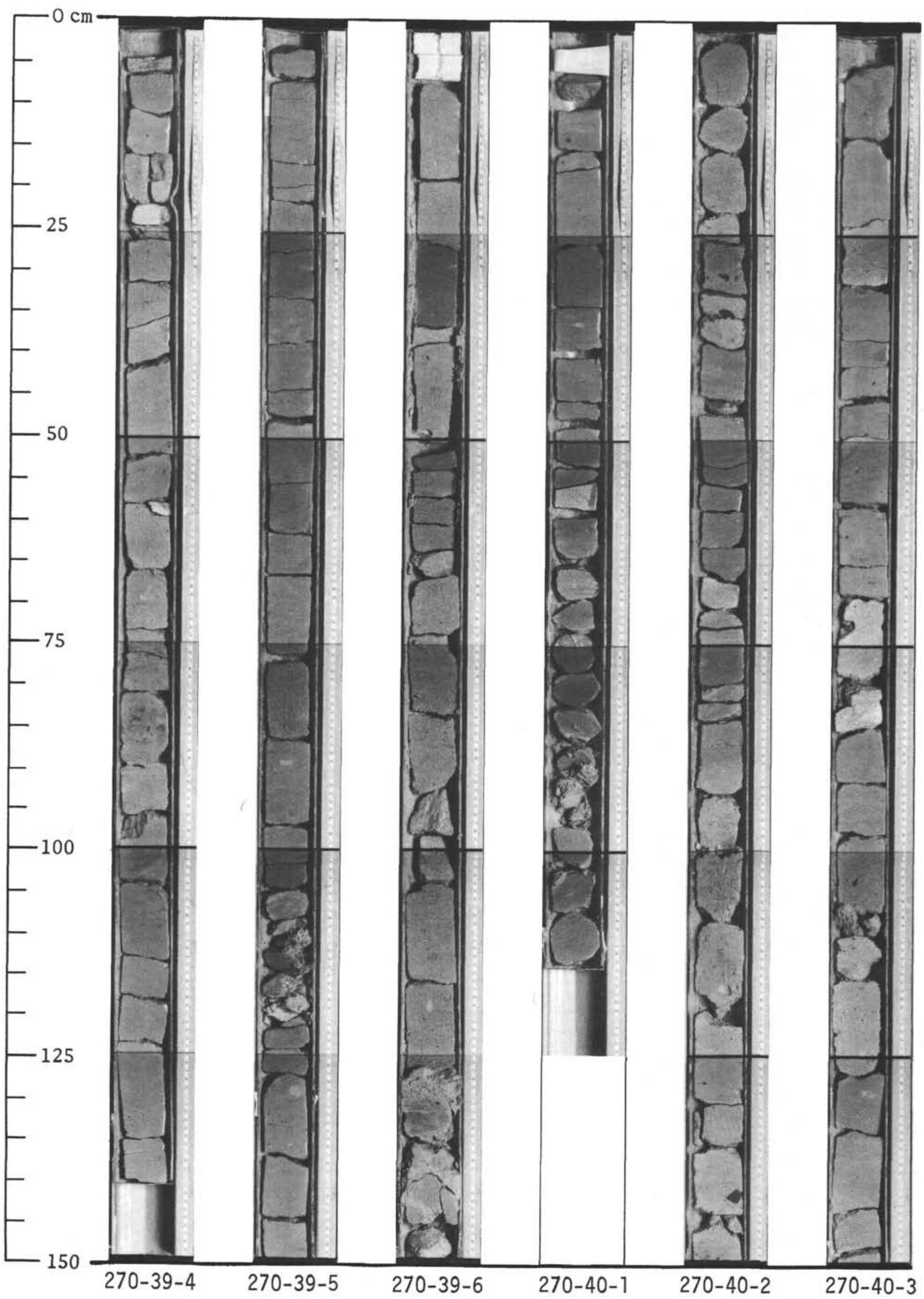




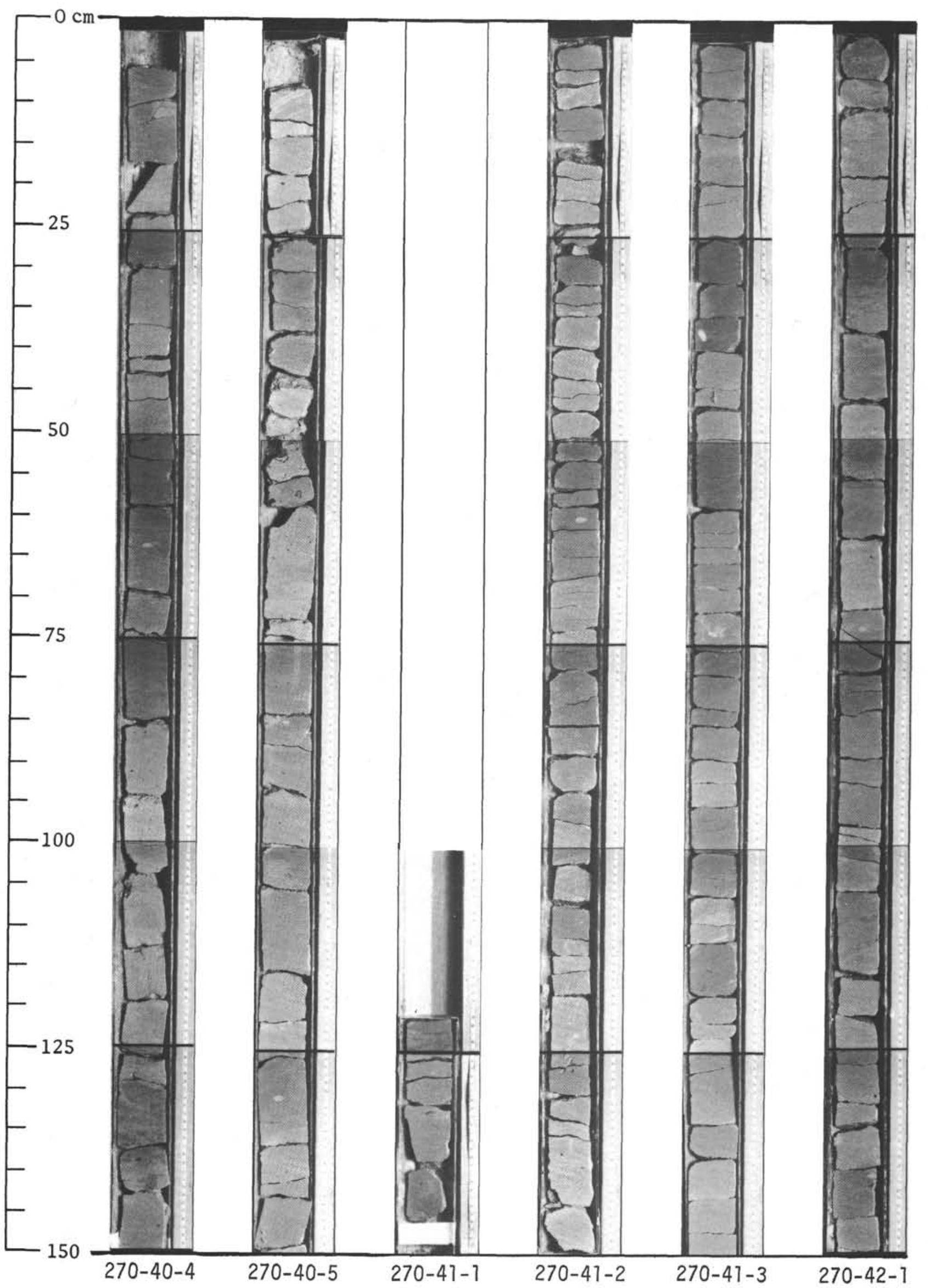


SITES 270, 271, 272

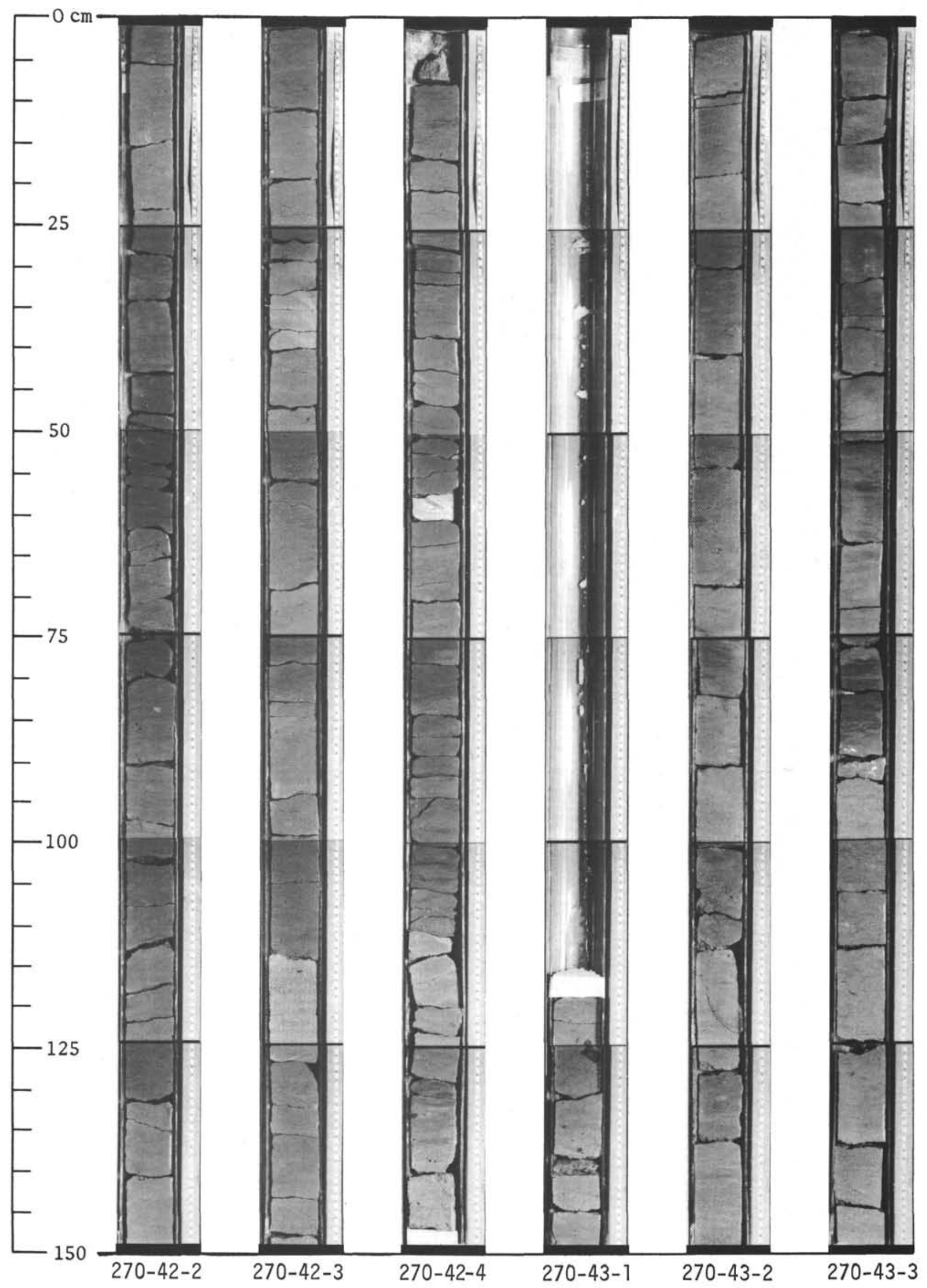




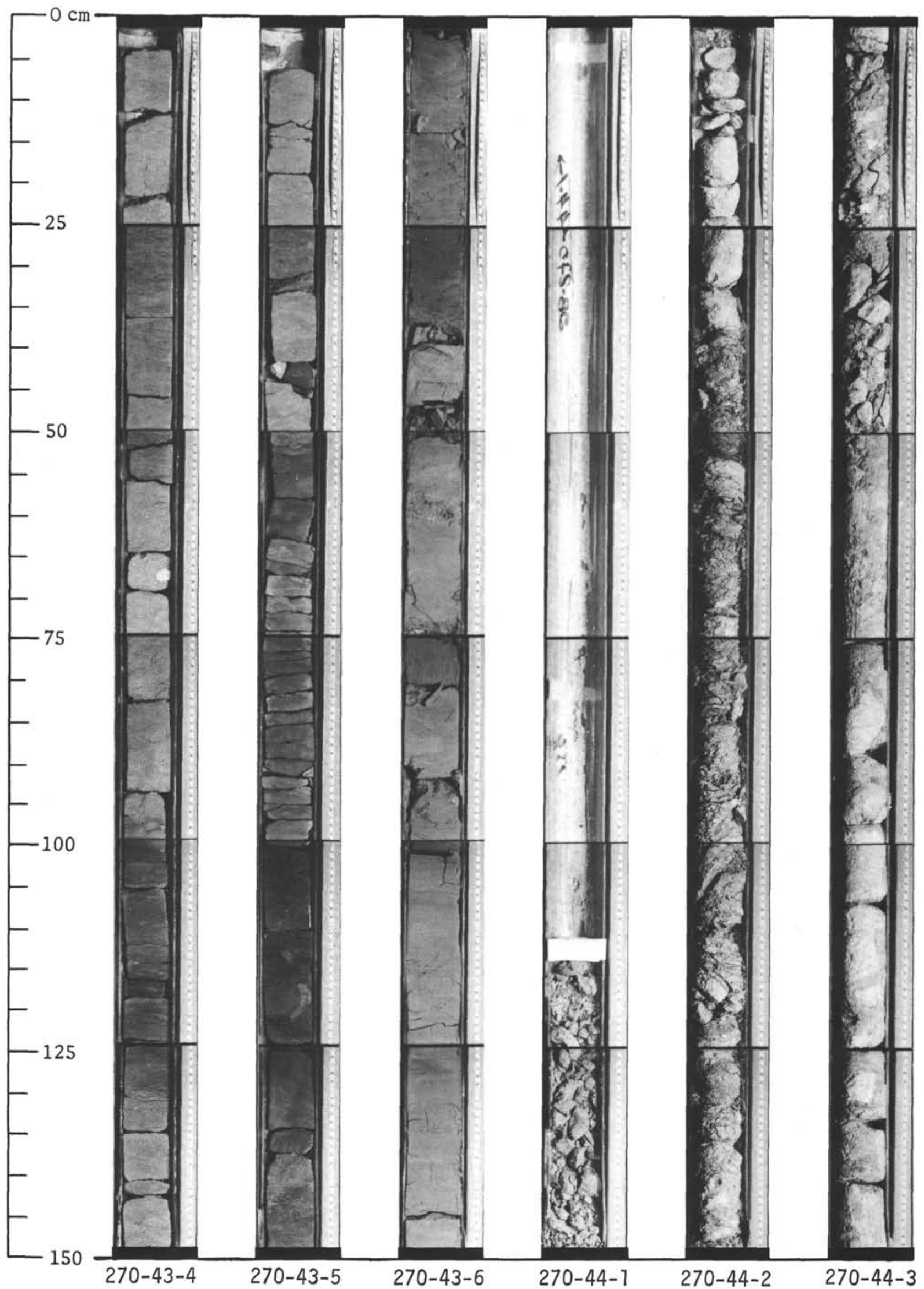




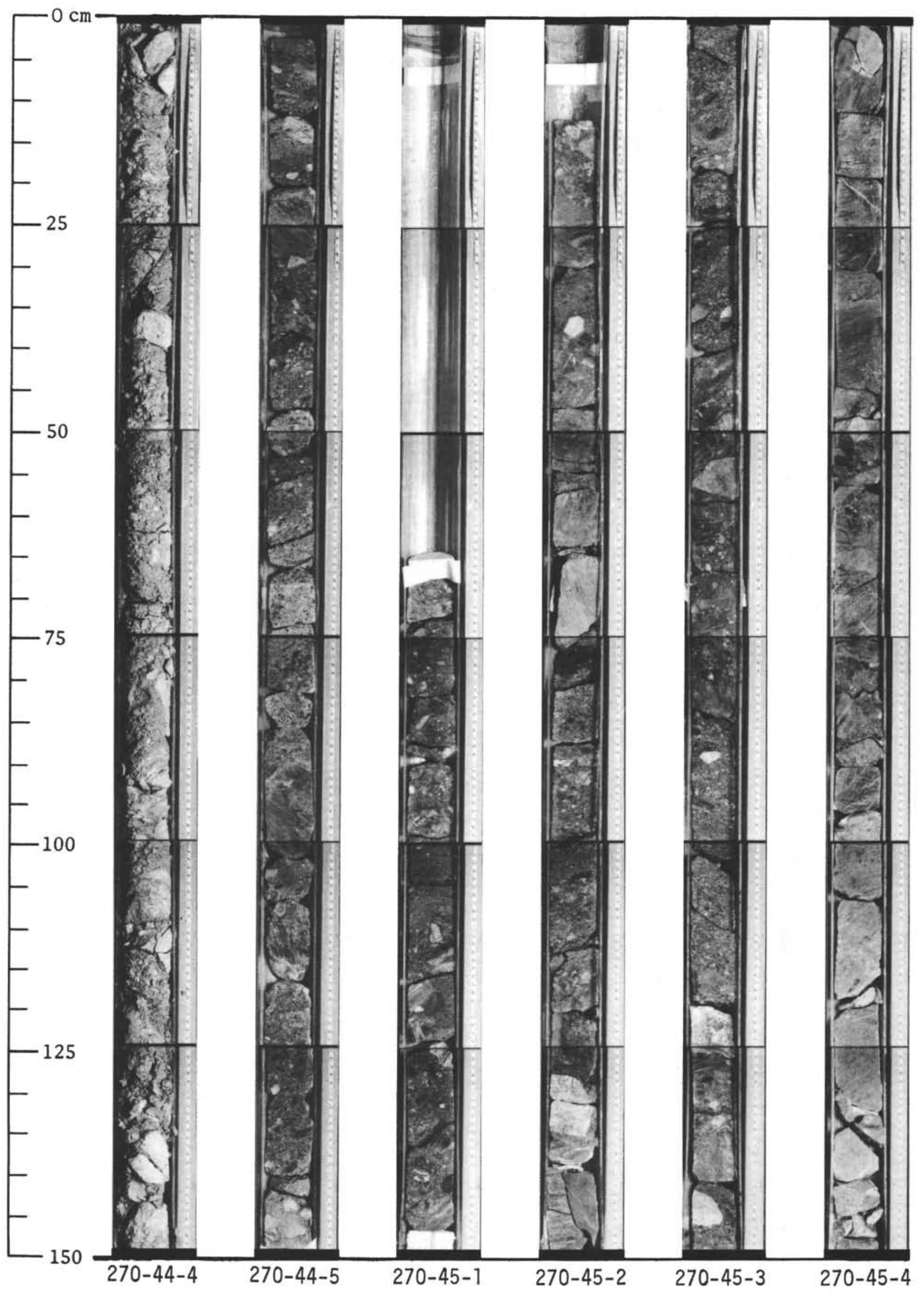




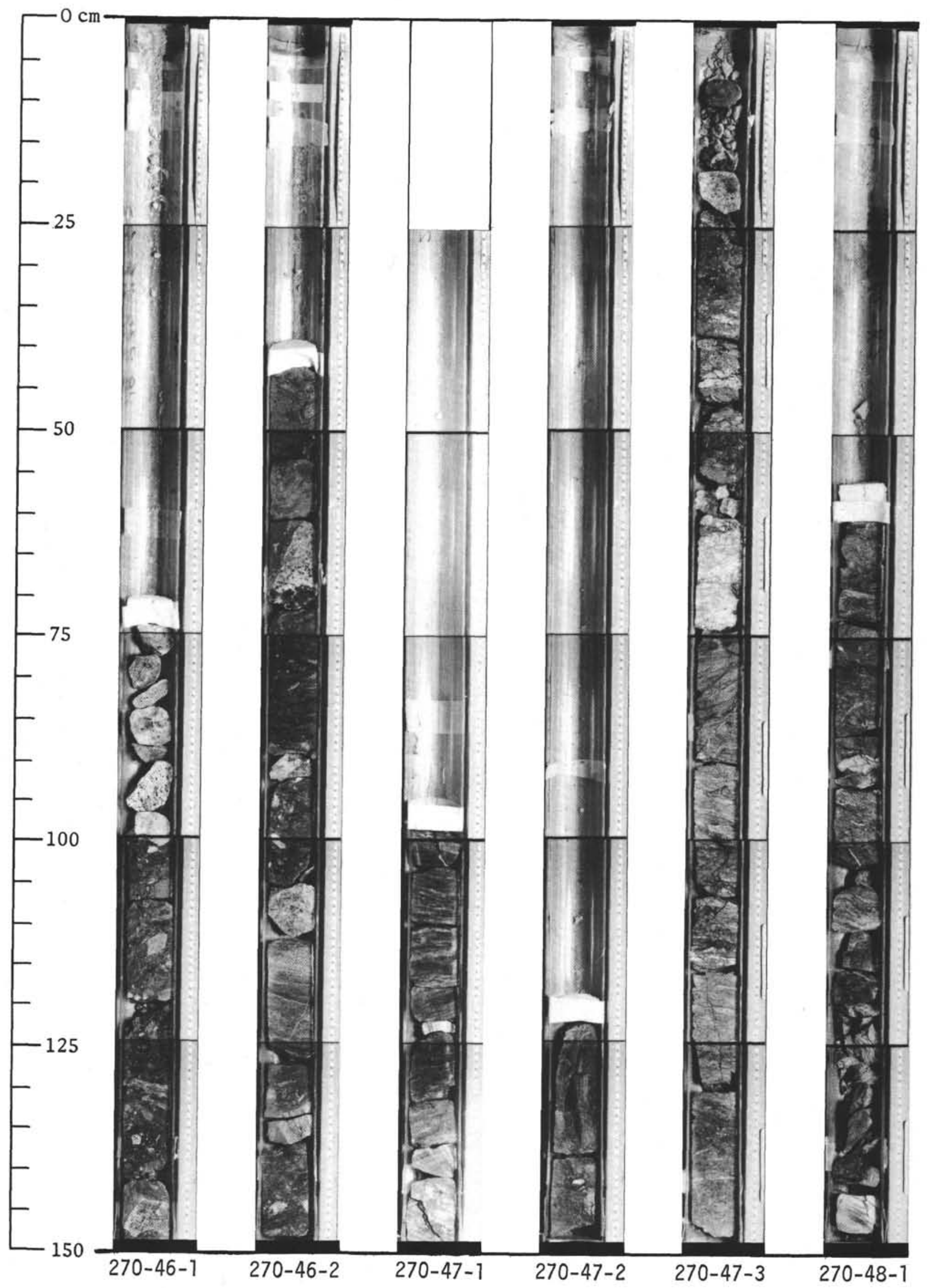


SITES 270, 271, 272

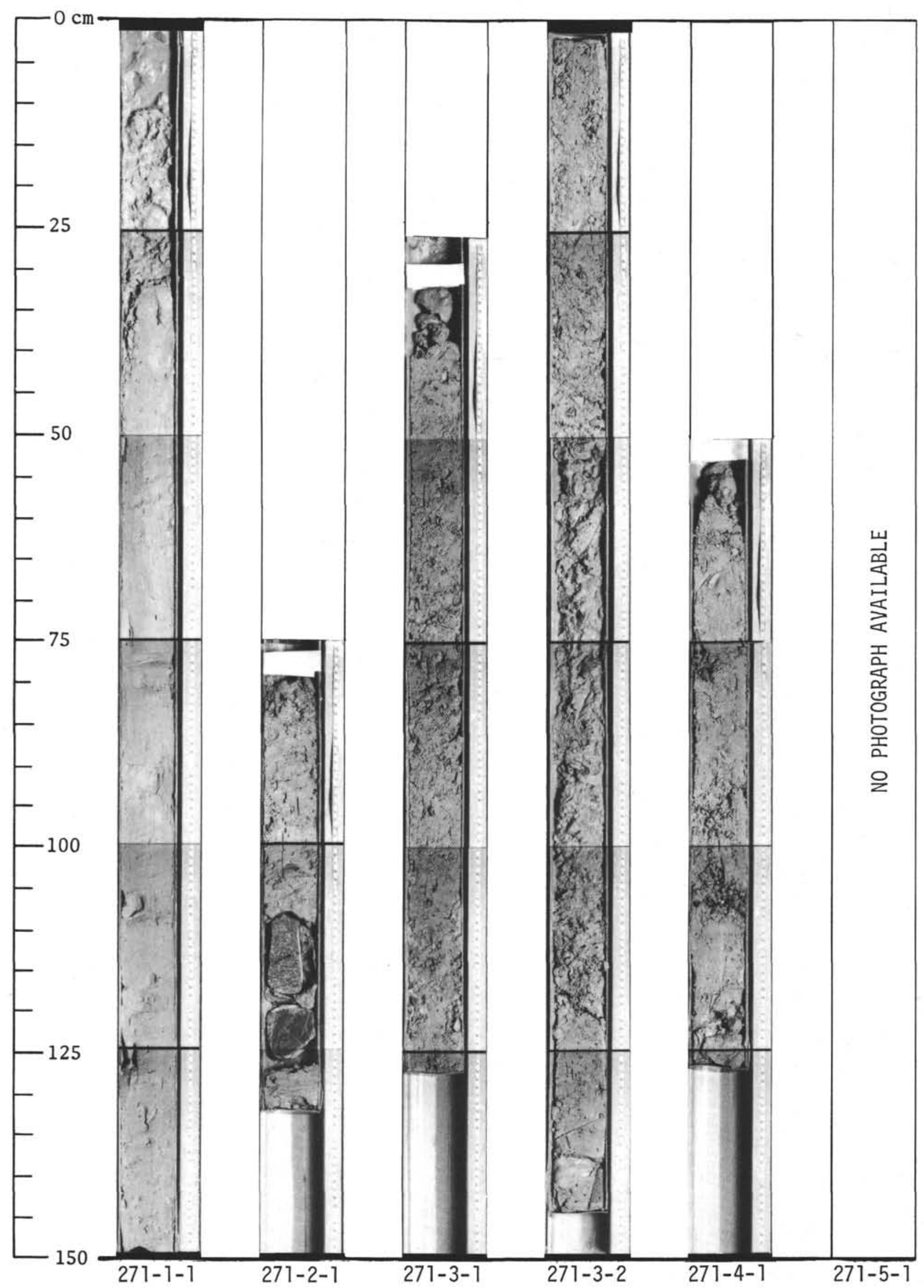




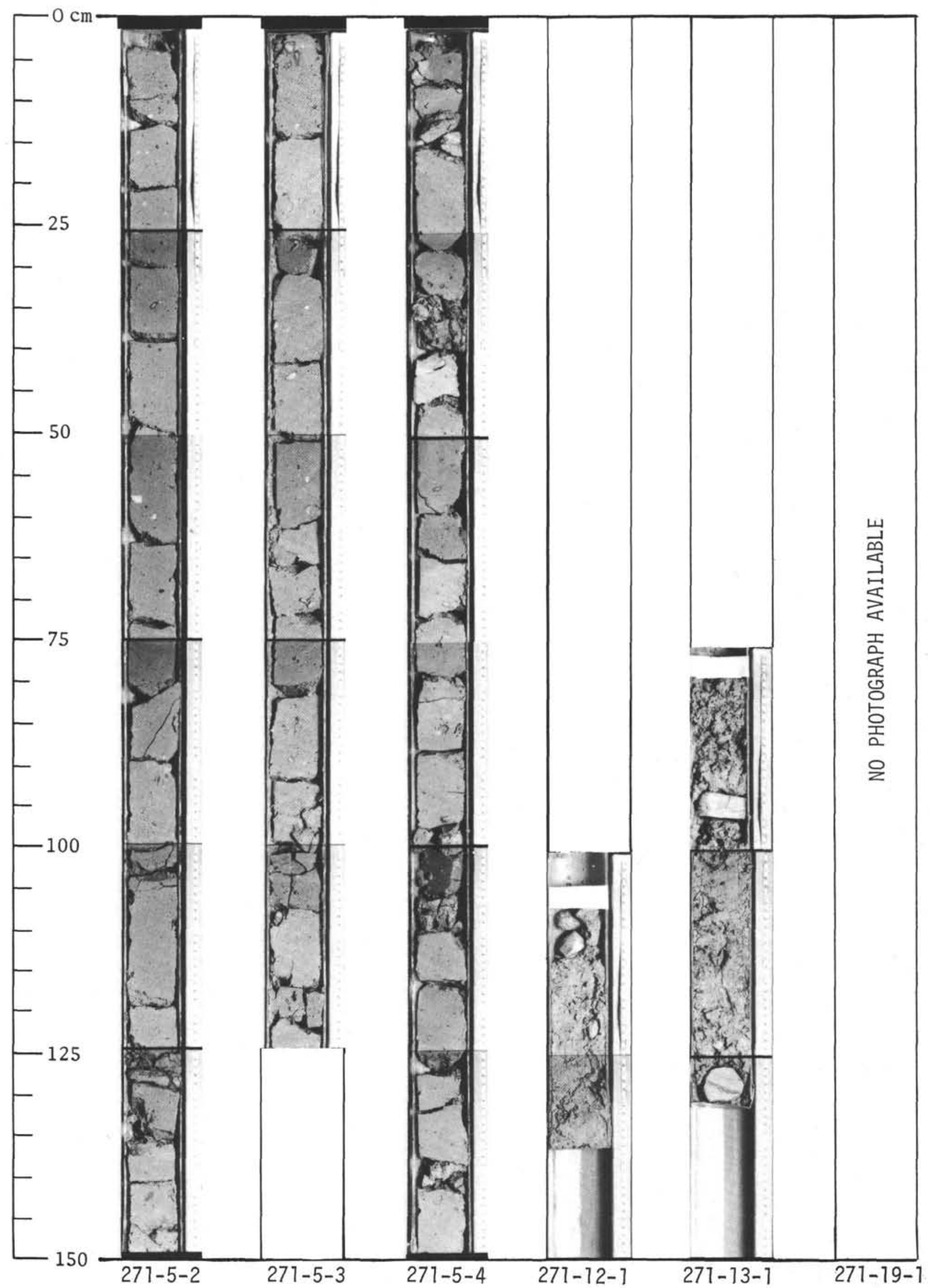


SITES $270,271,272$

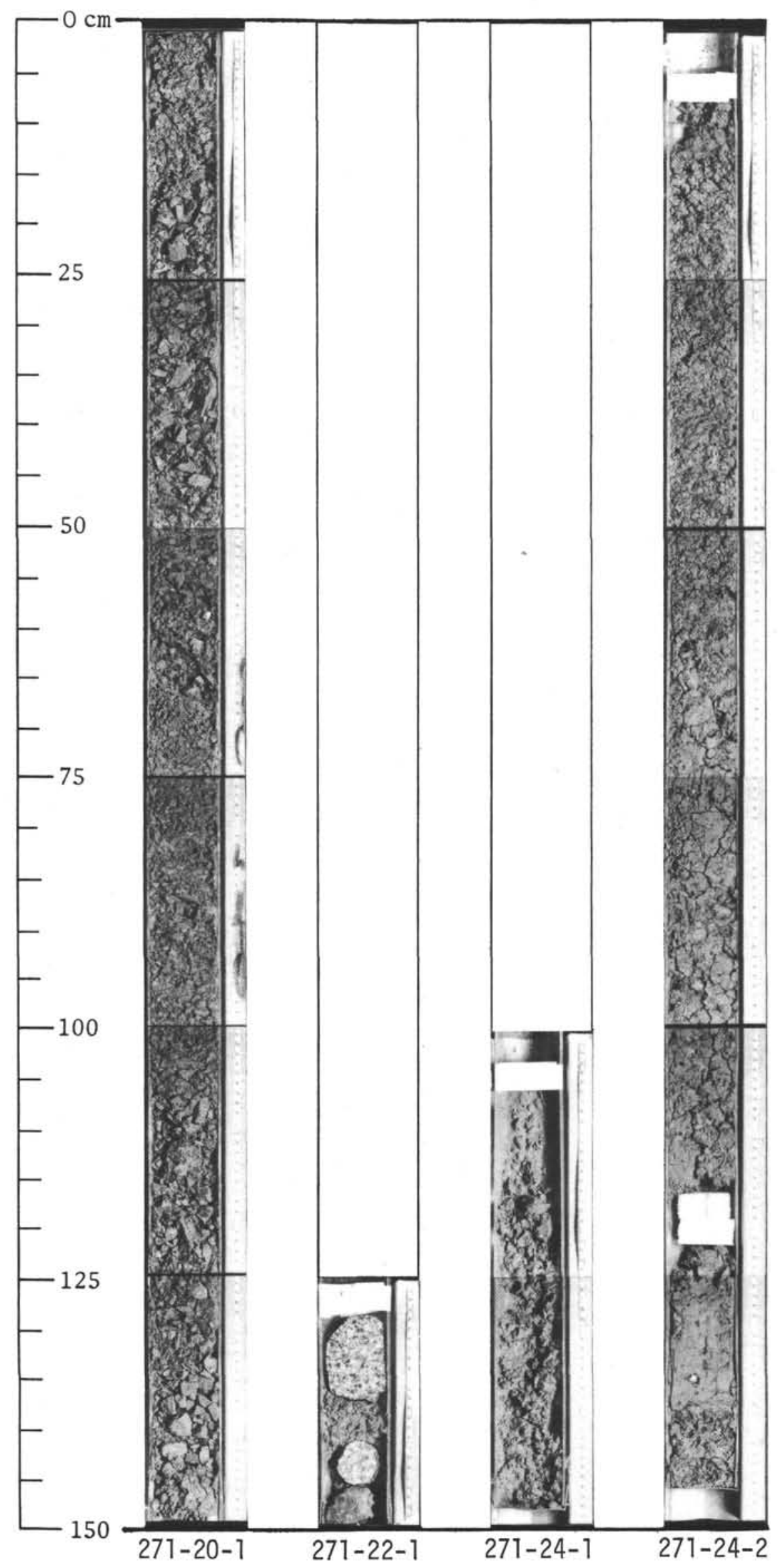




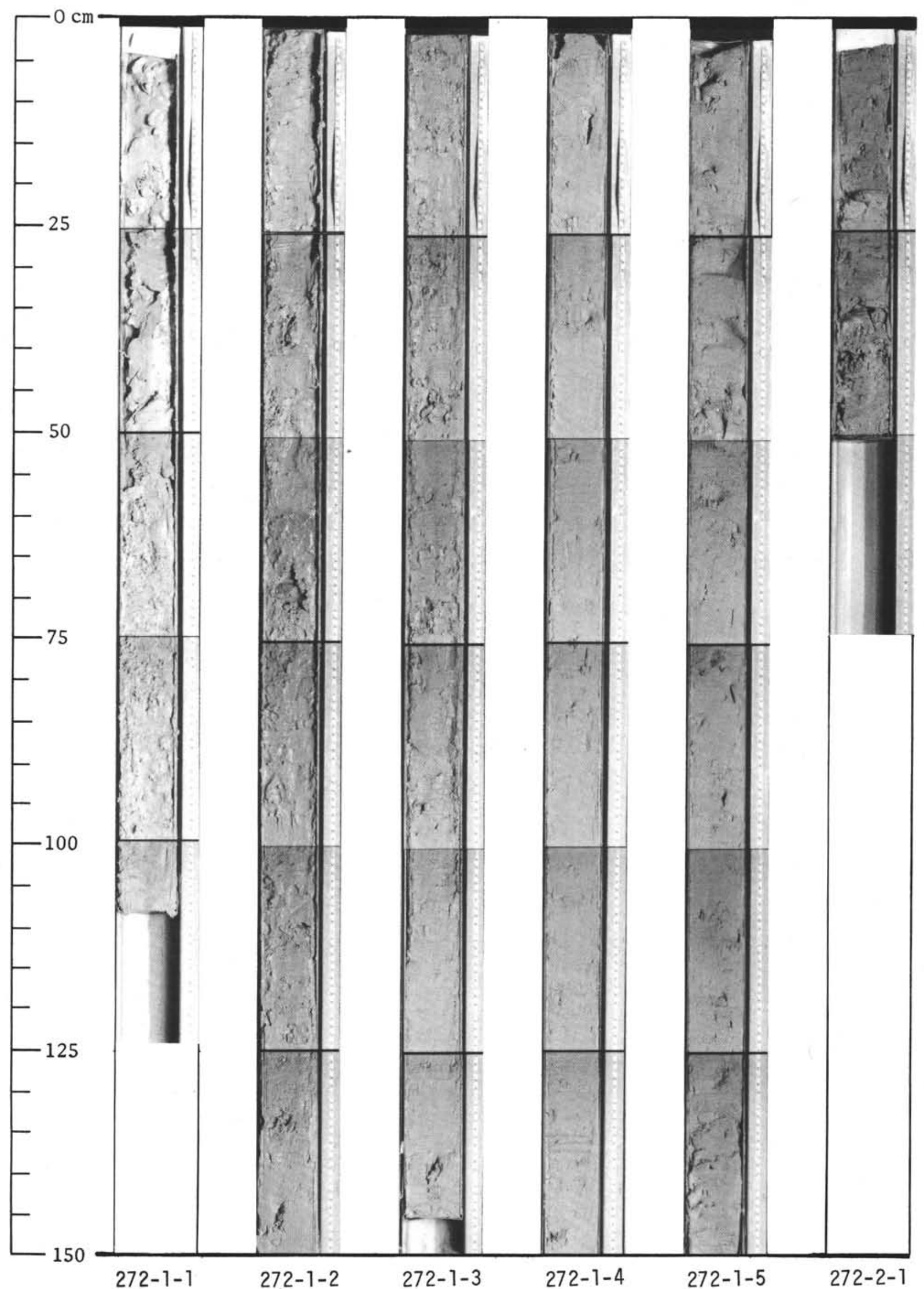




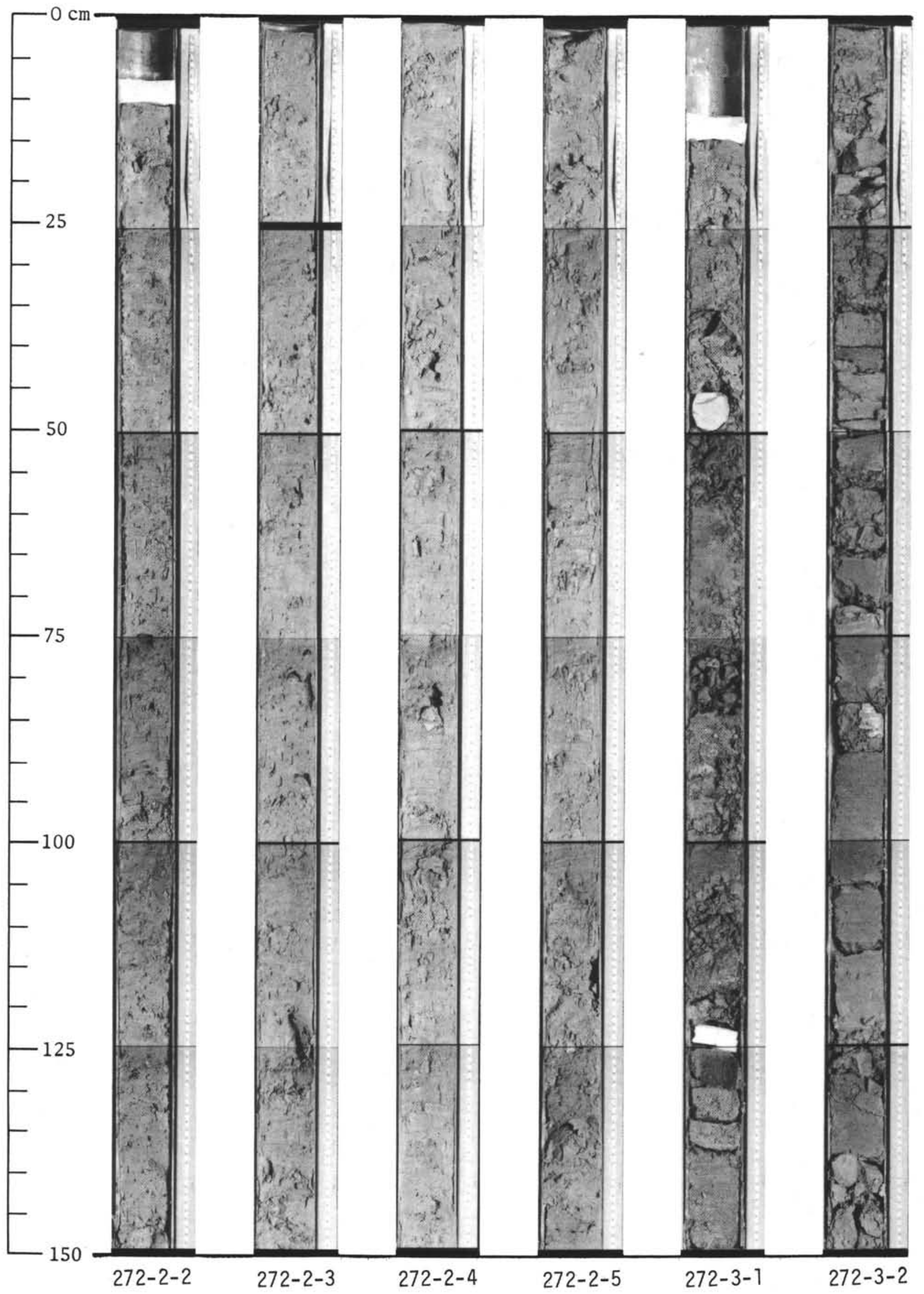




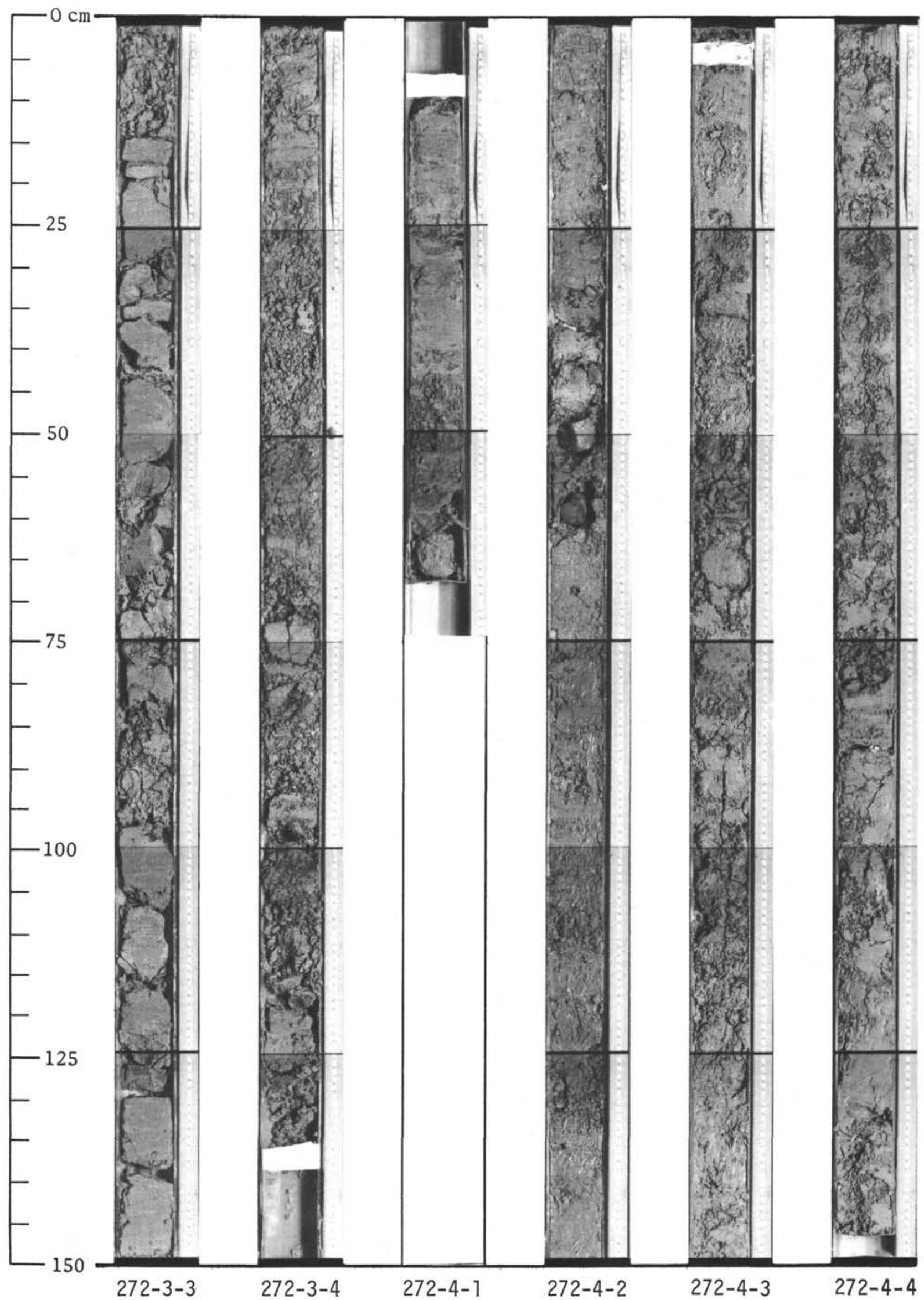


SITES 270, 271, 272

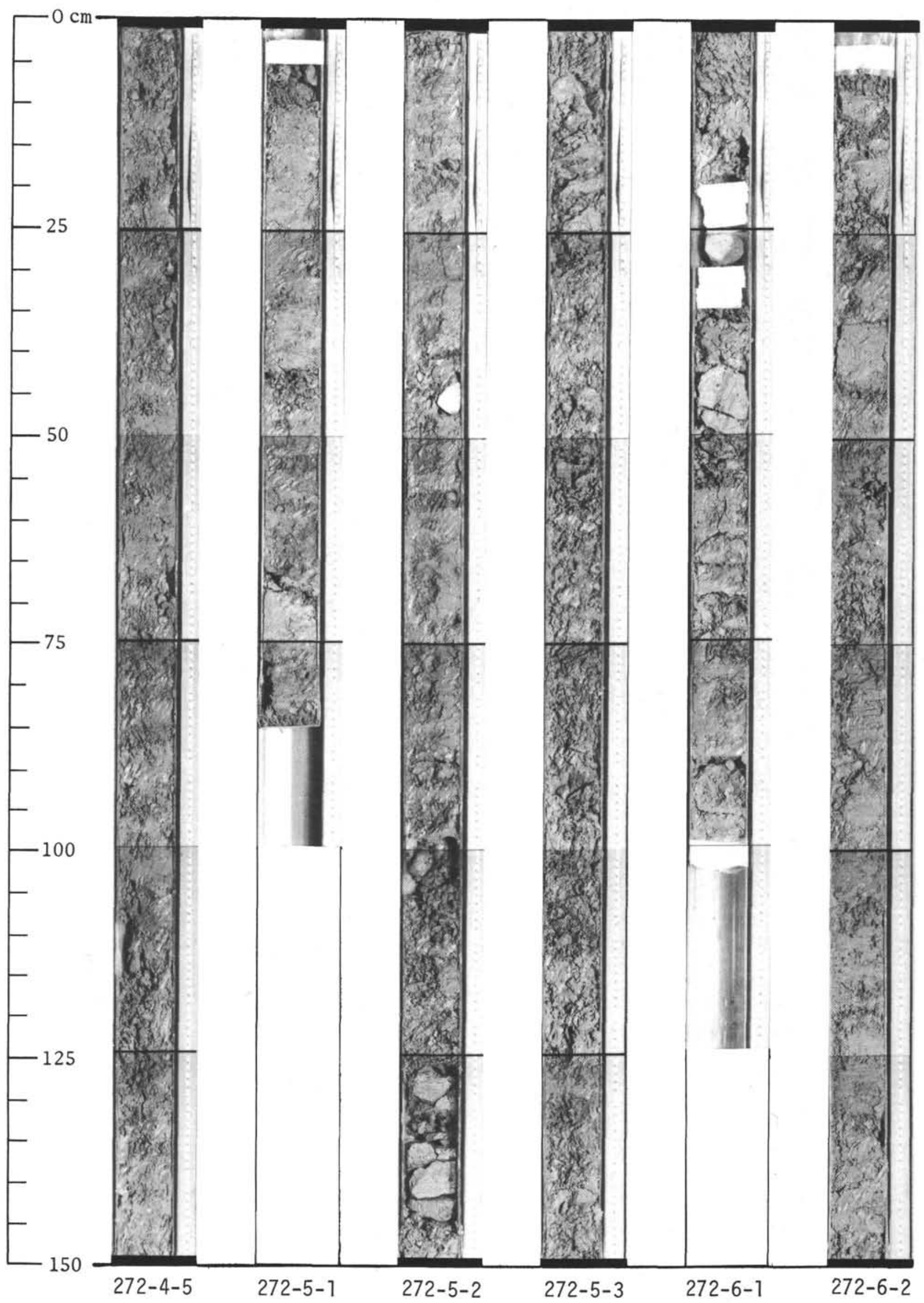




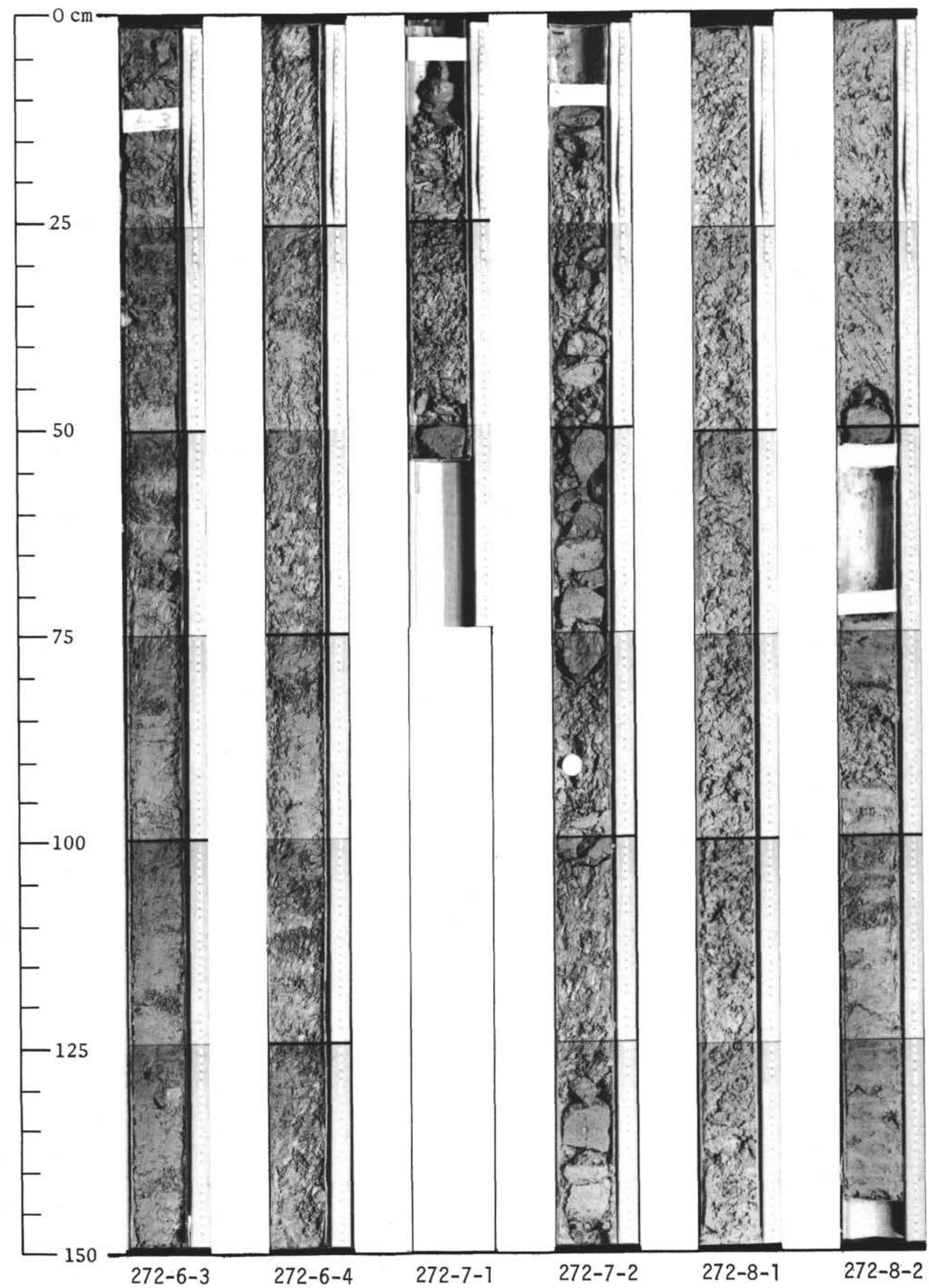


SITES 270, 271, 272

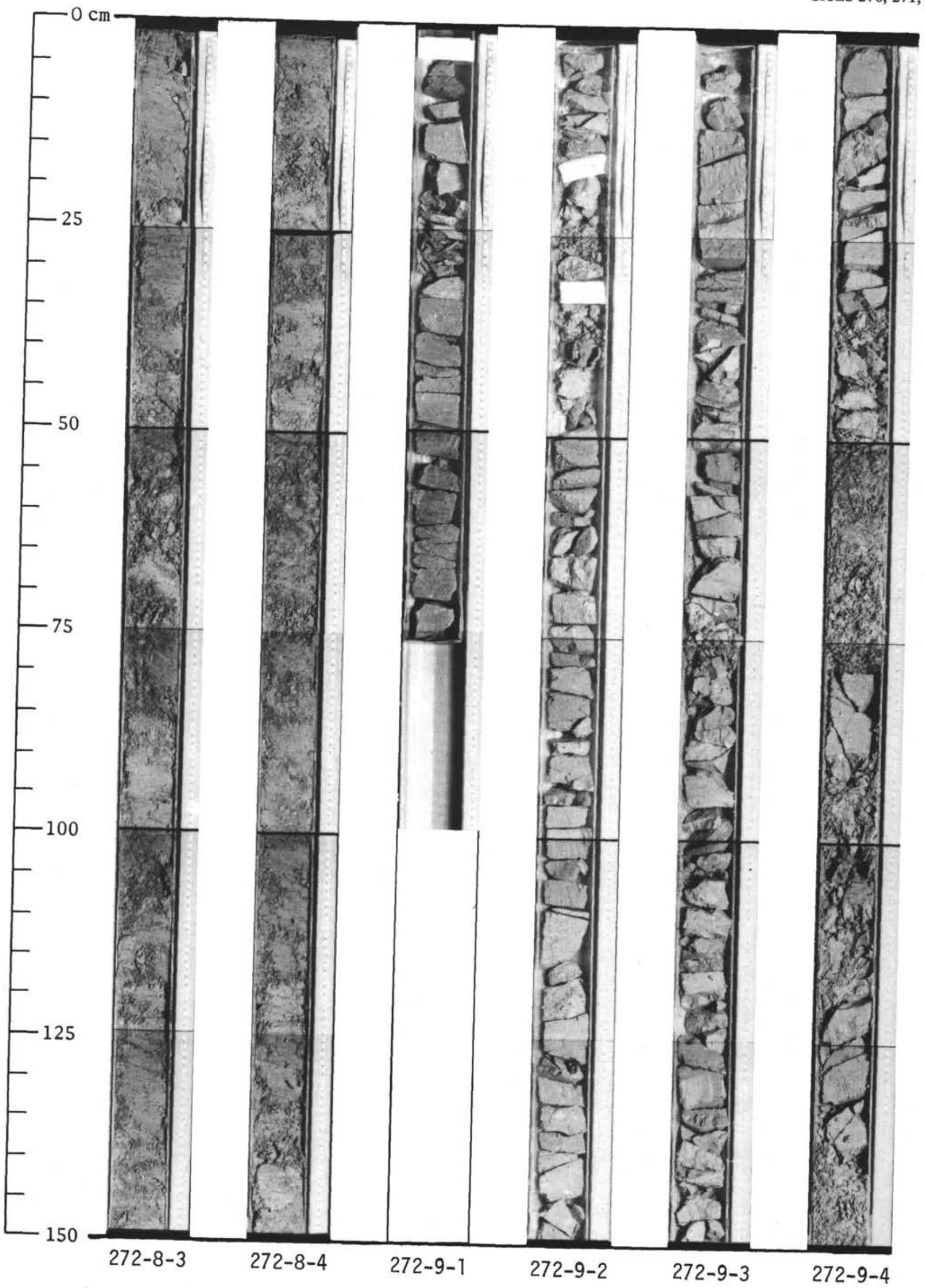




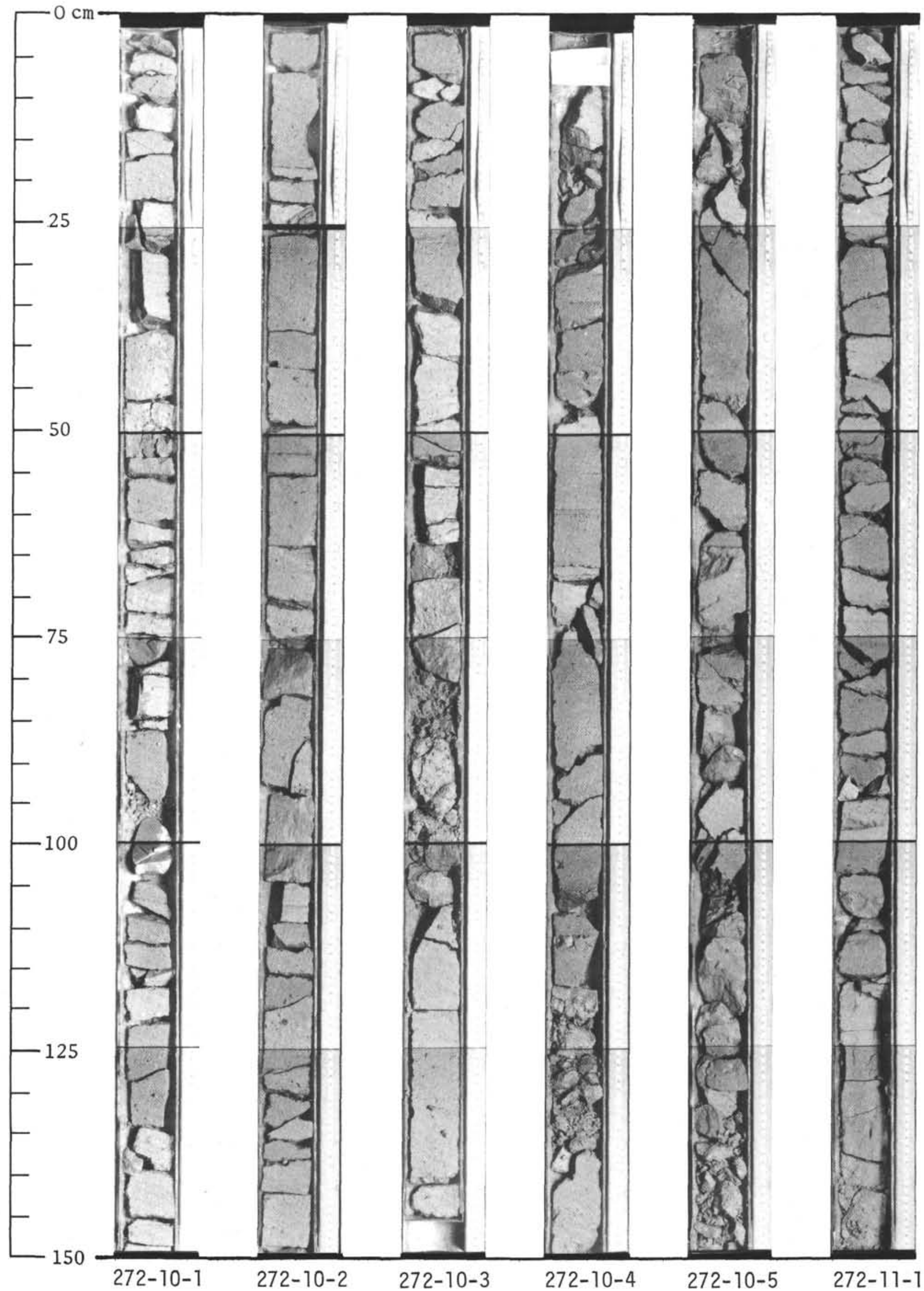


SITES 270, 271, 272

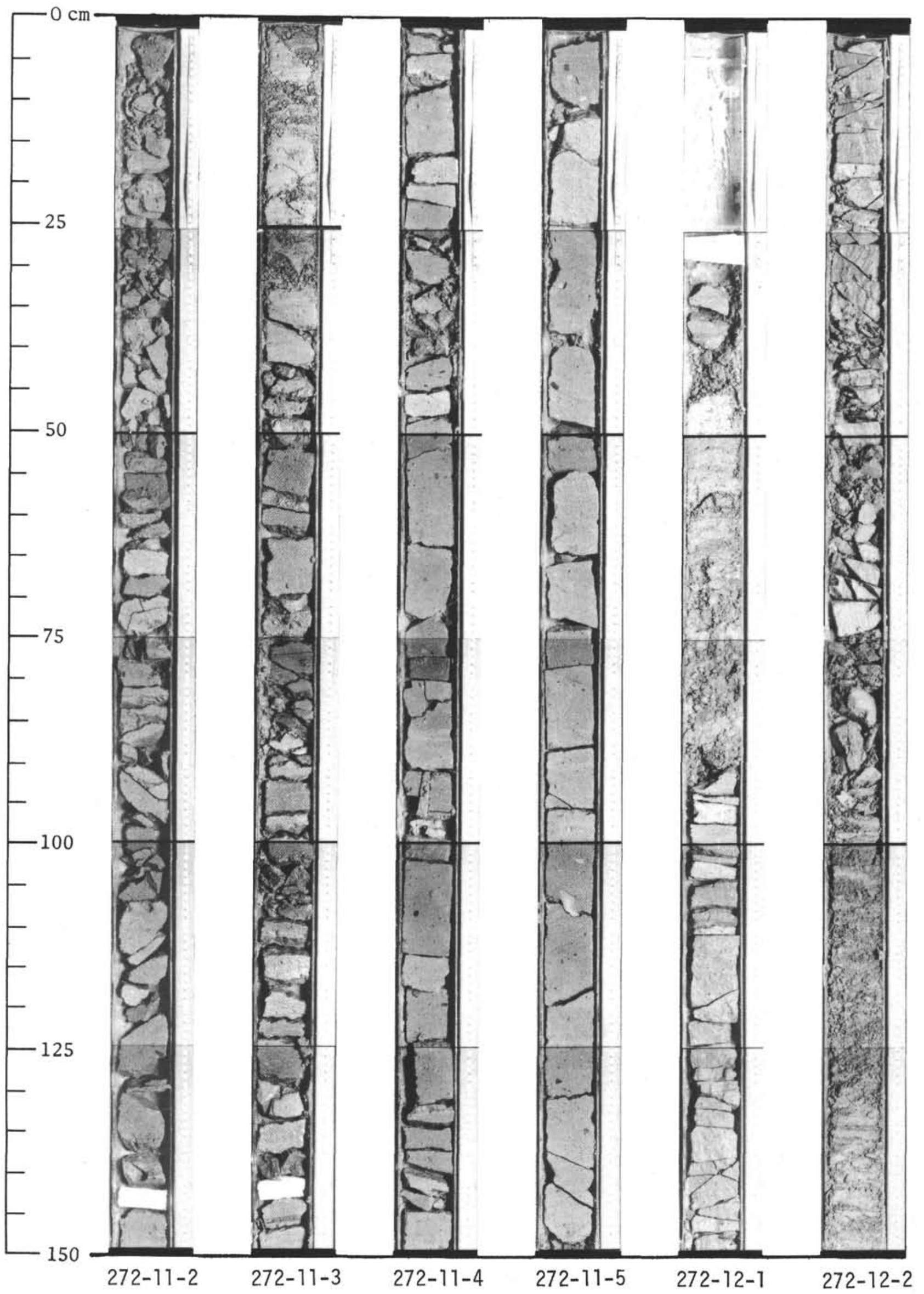




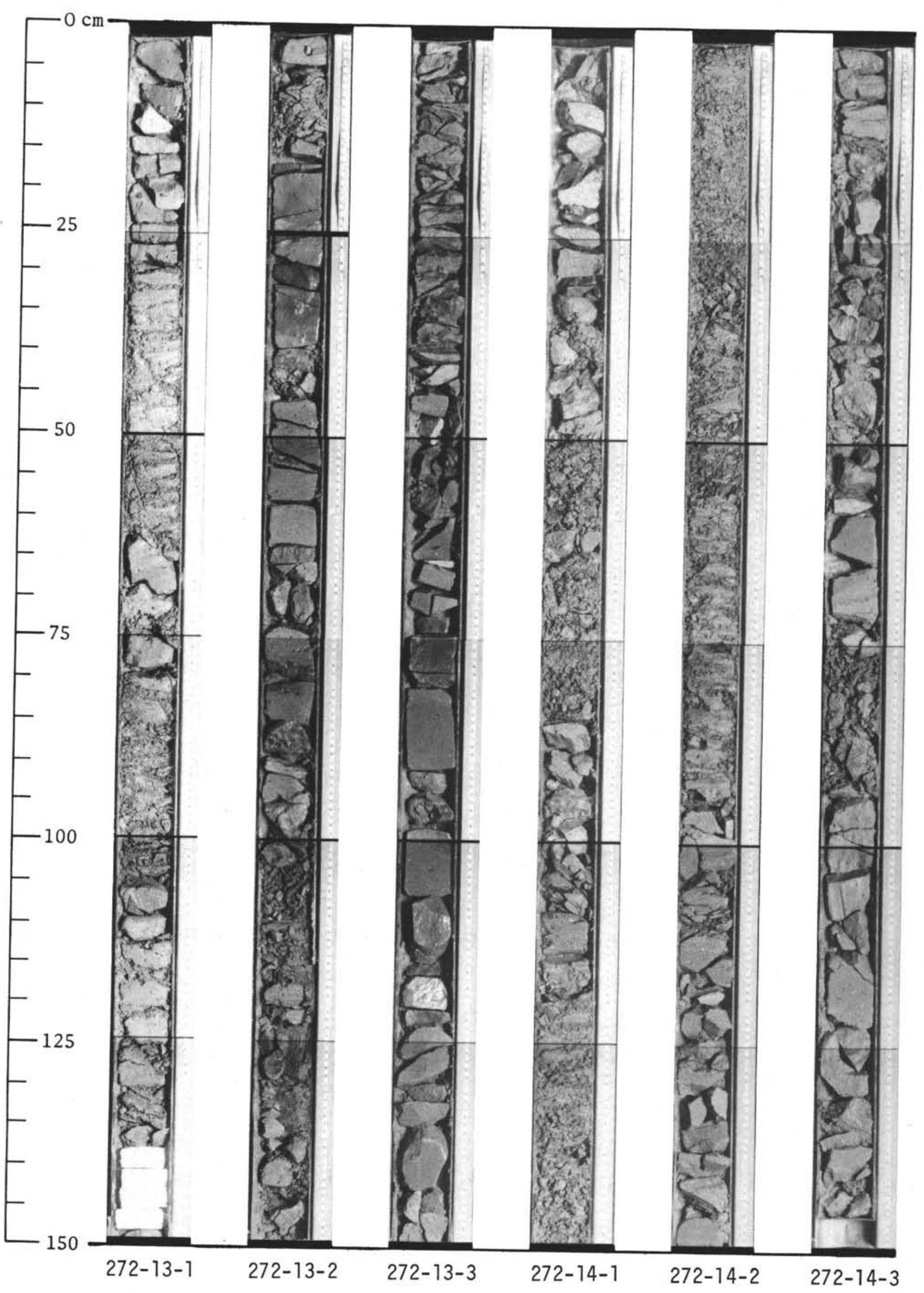


SITES 270, 271, 272

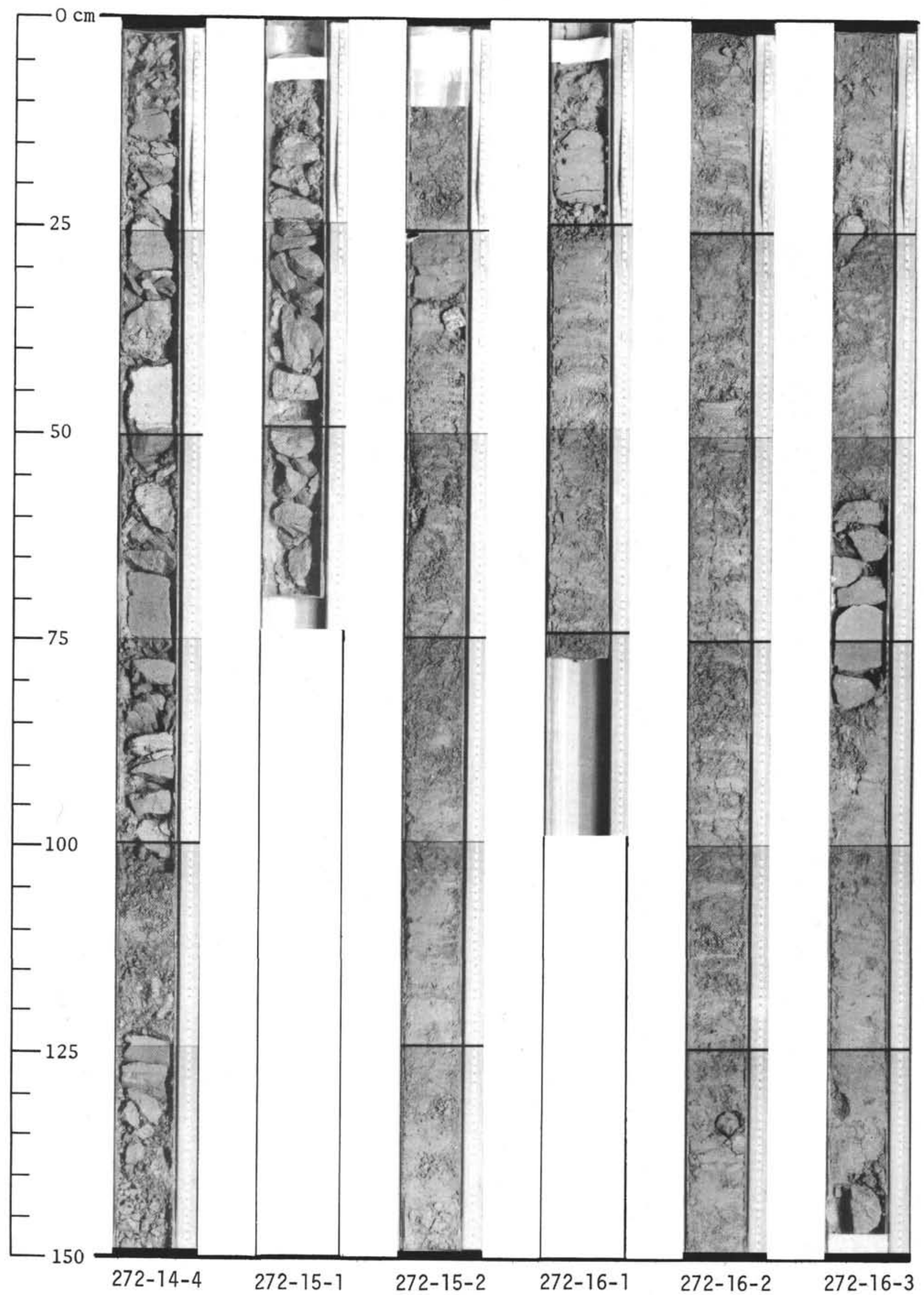




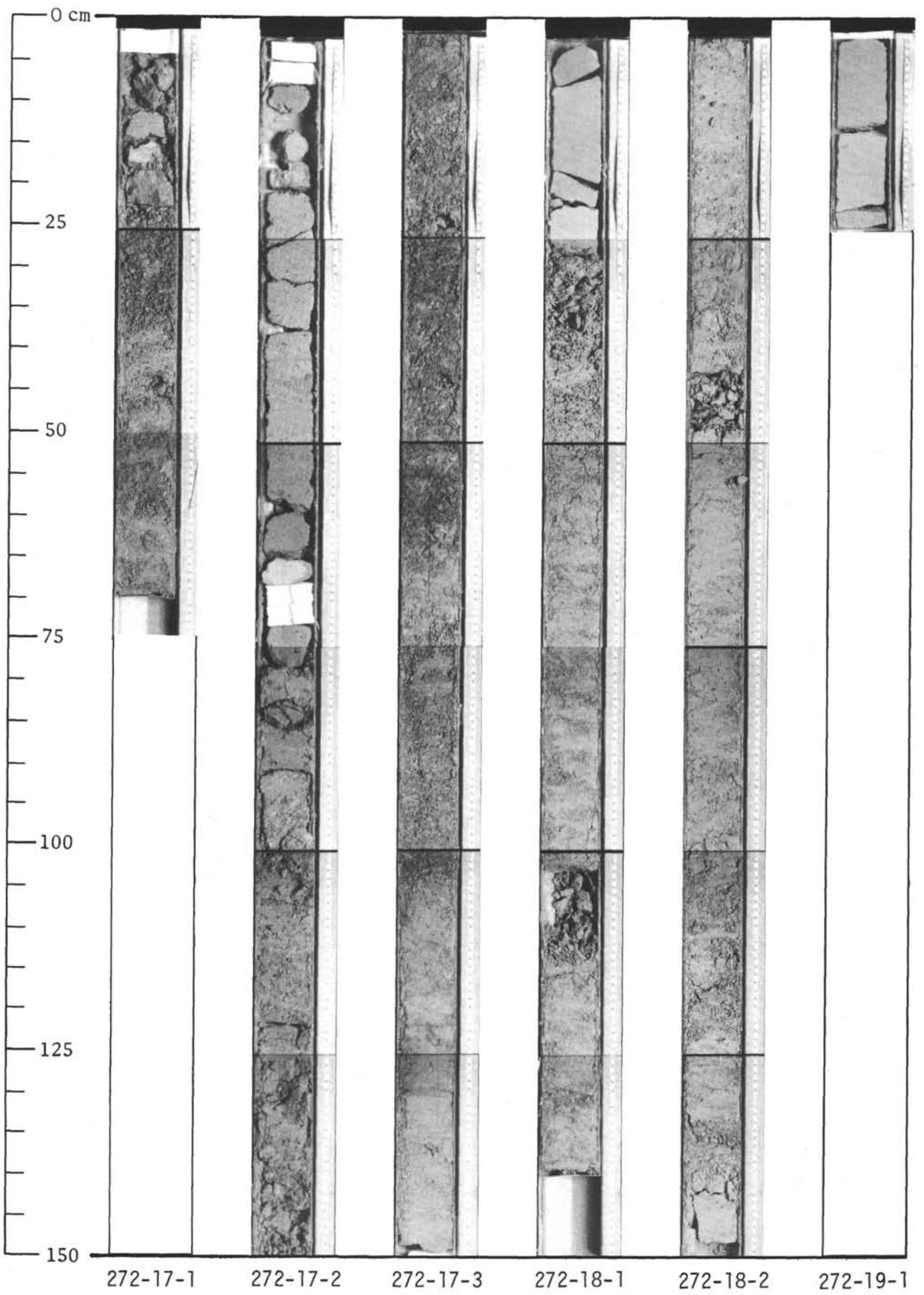


SITES 270, 271, 272

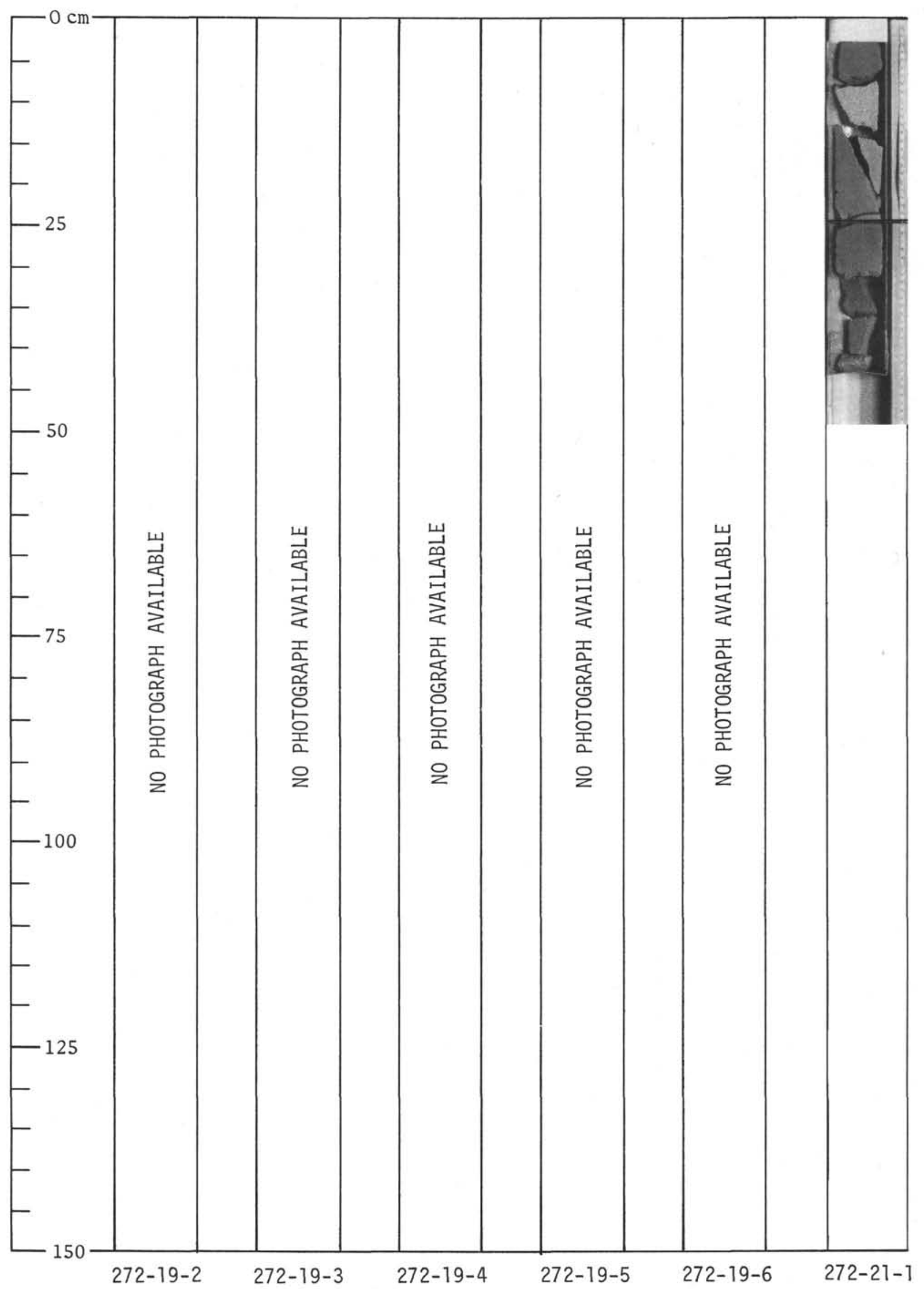




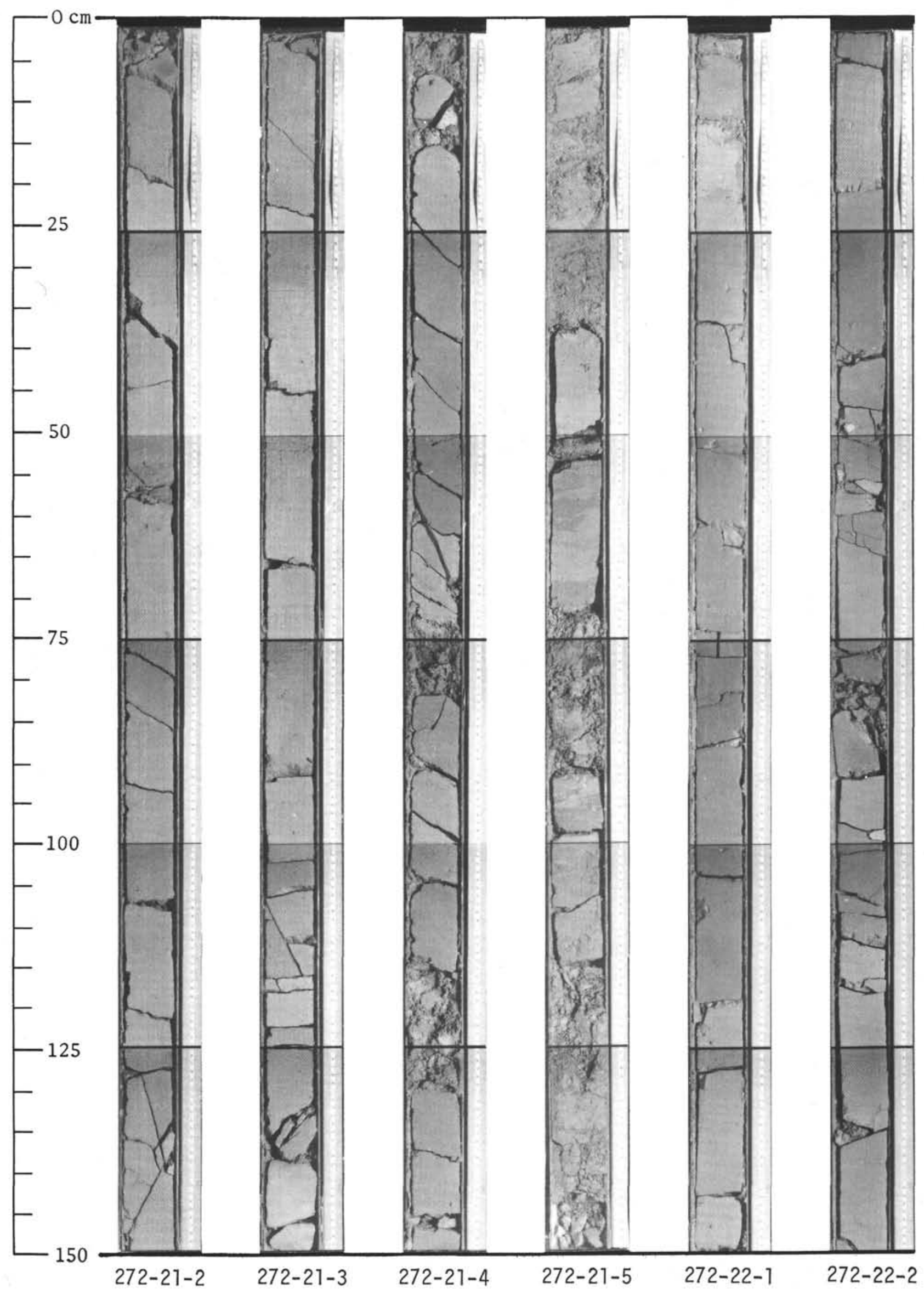




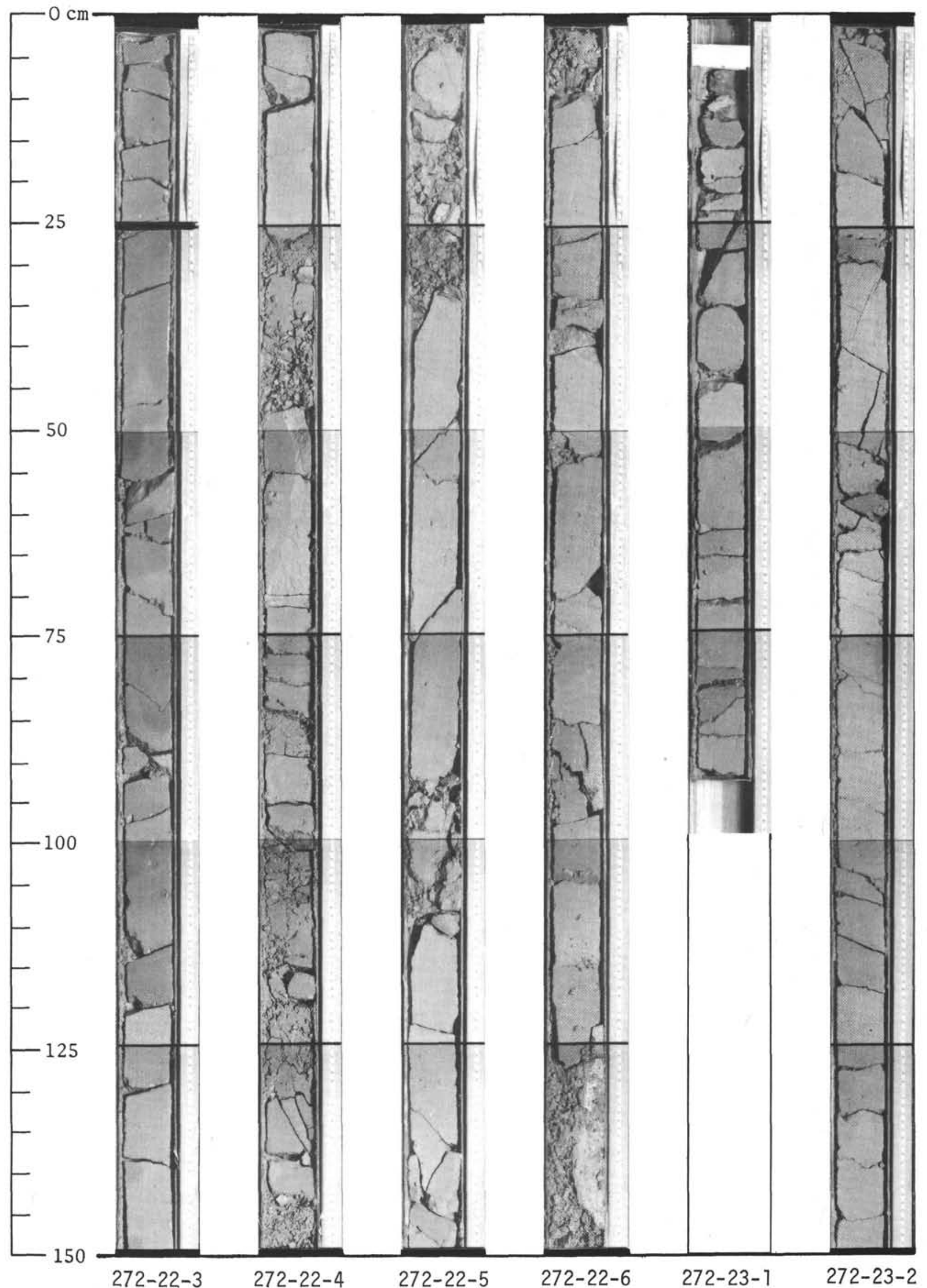


SITES 270, 271, 272

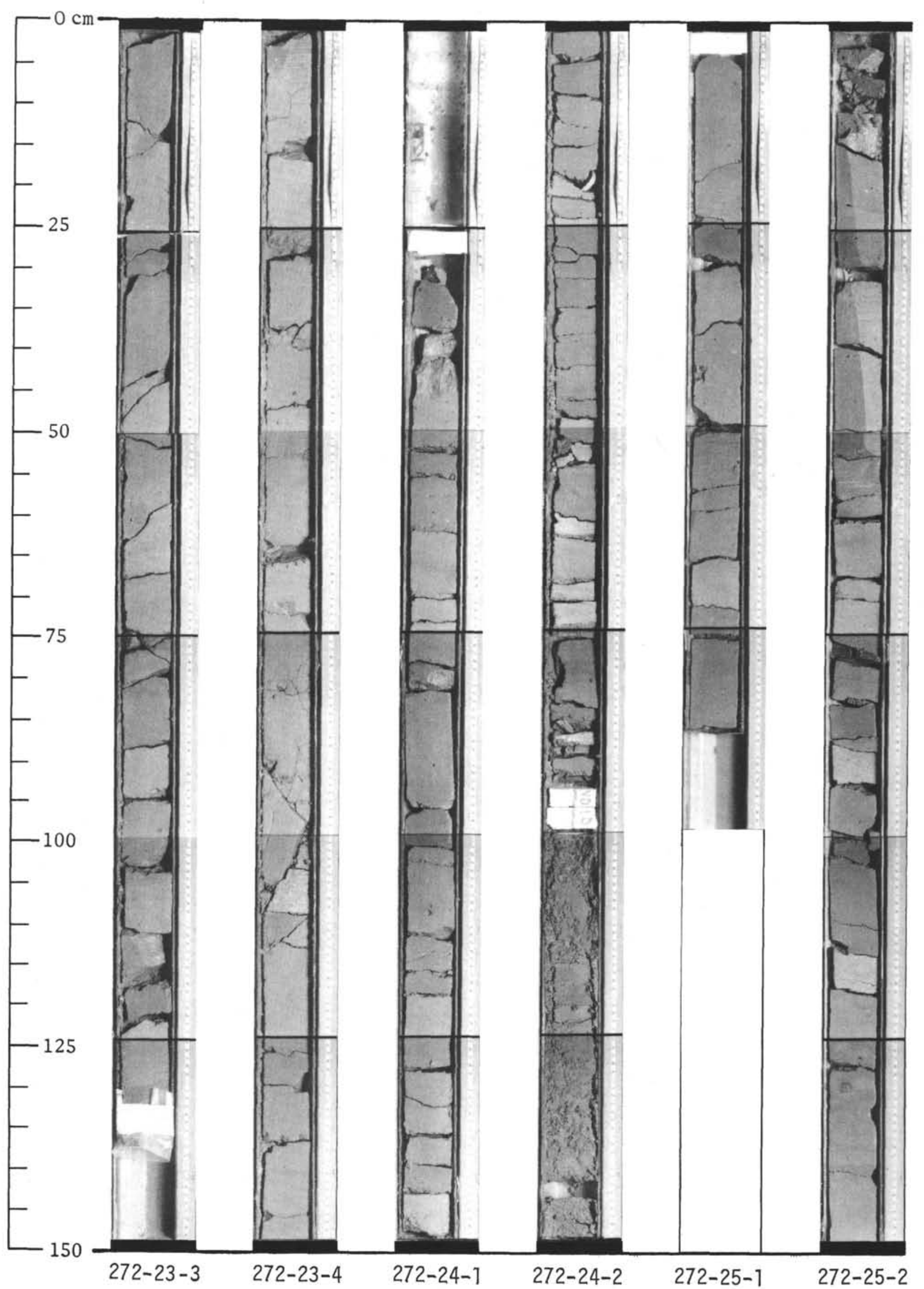


SITES 270, 271, 272

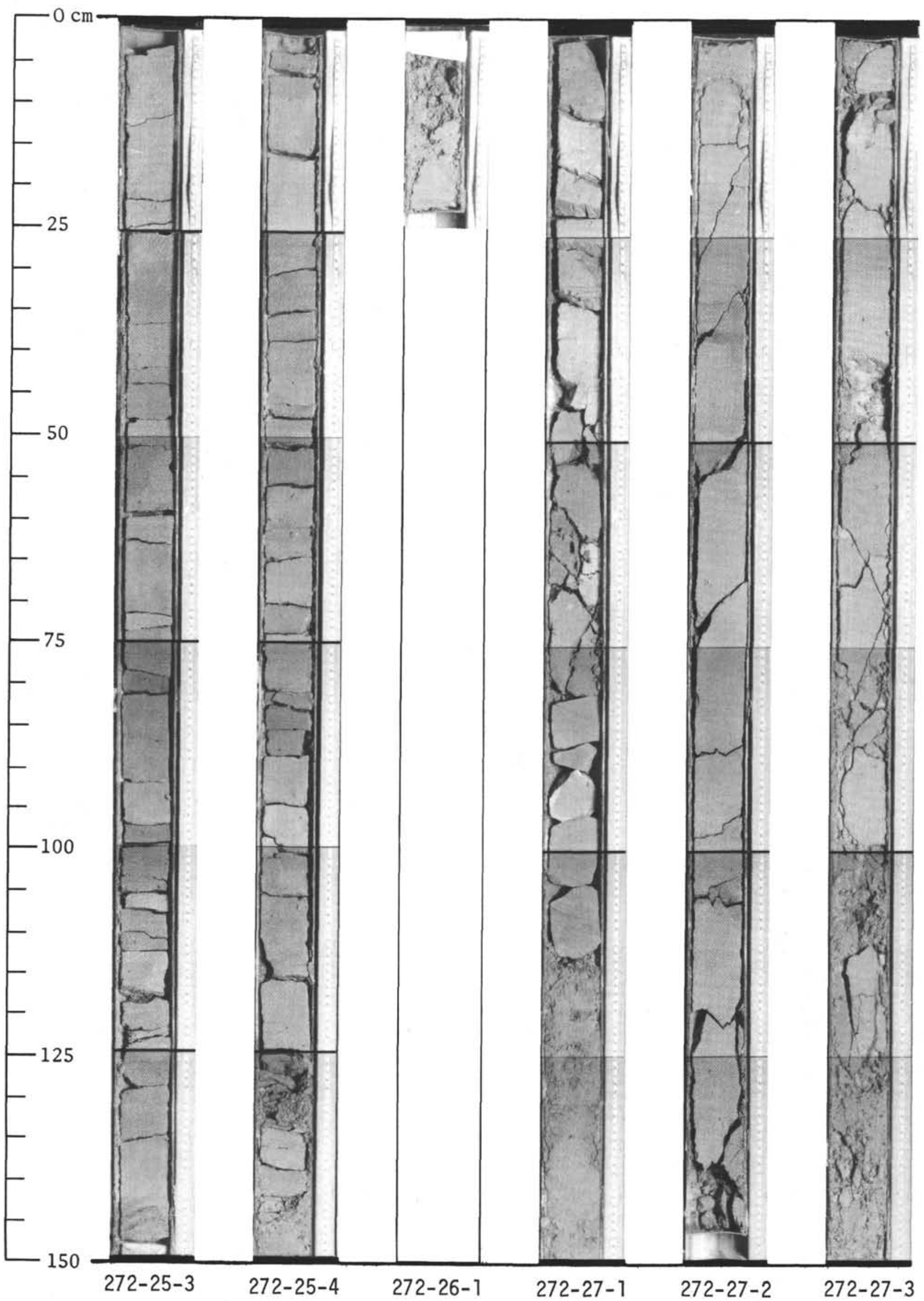




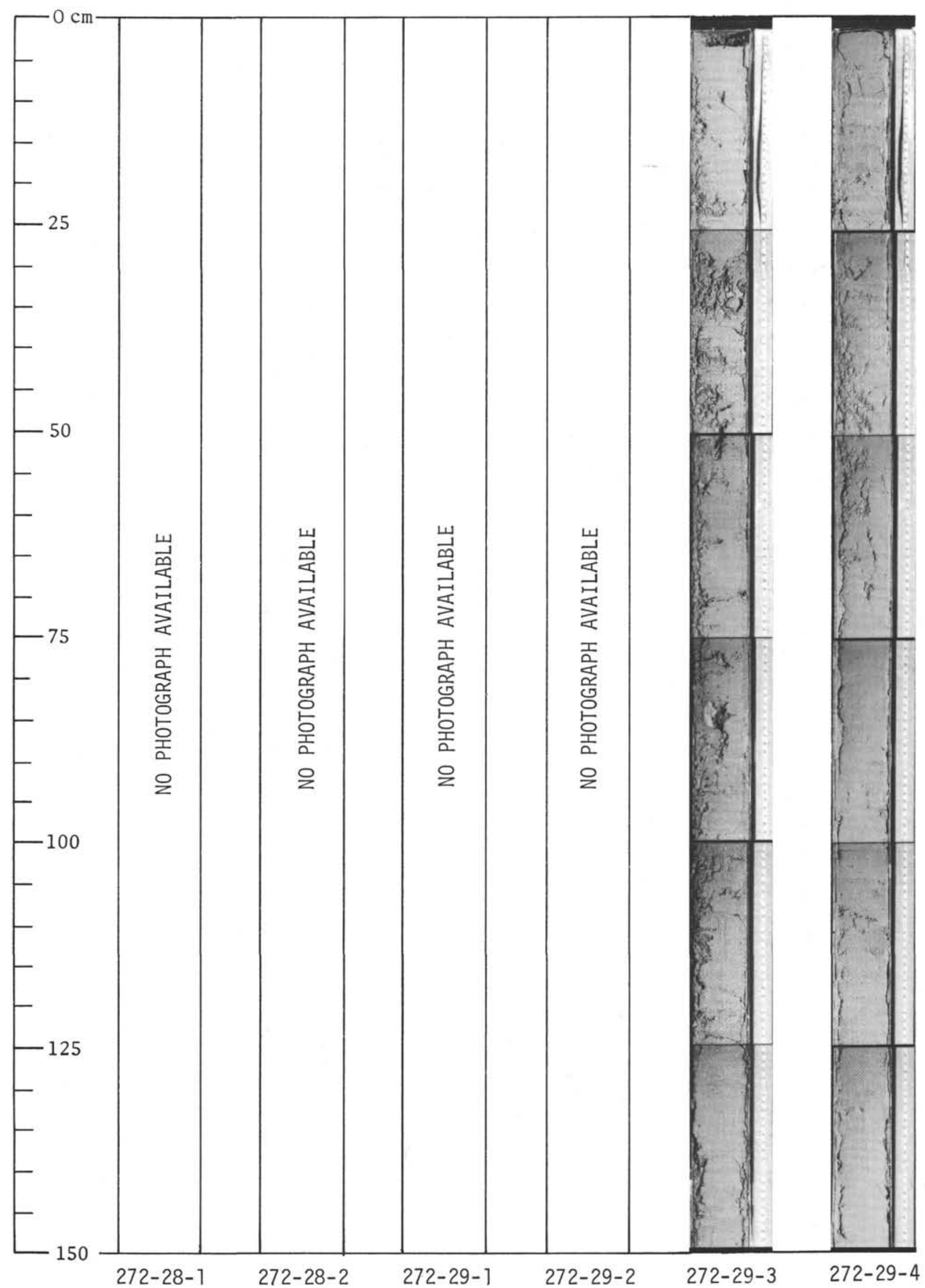


SITES 270, 271, 272

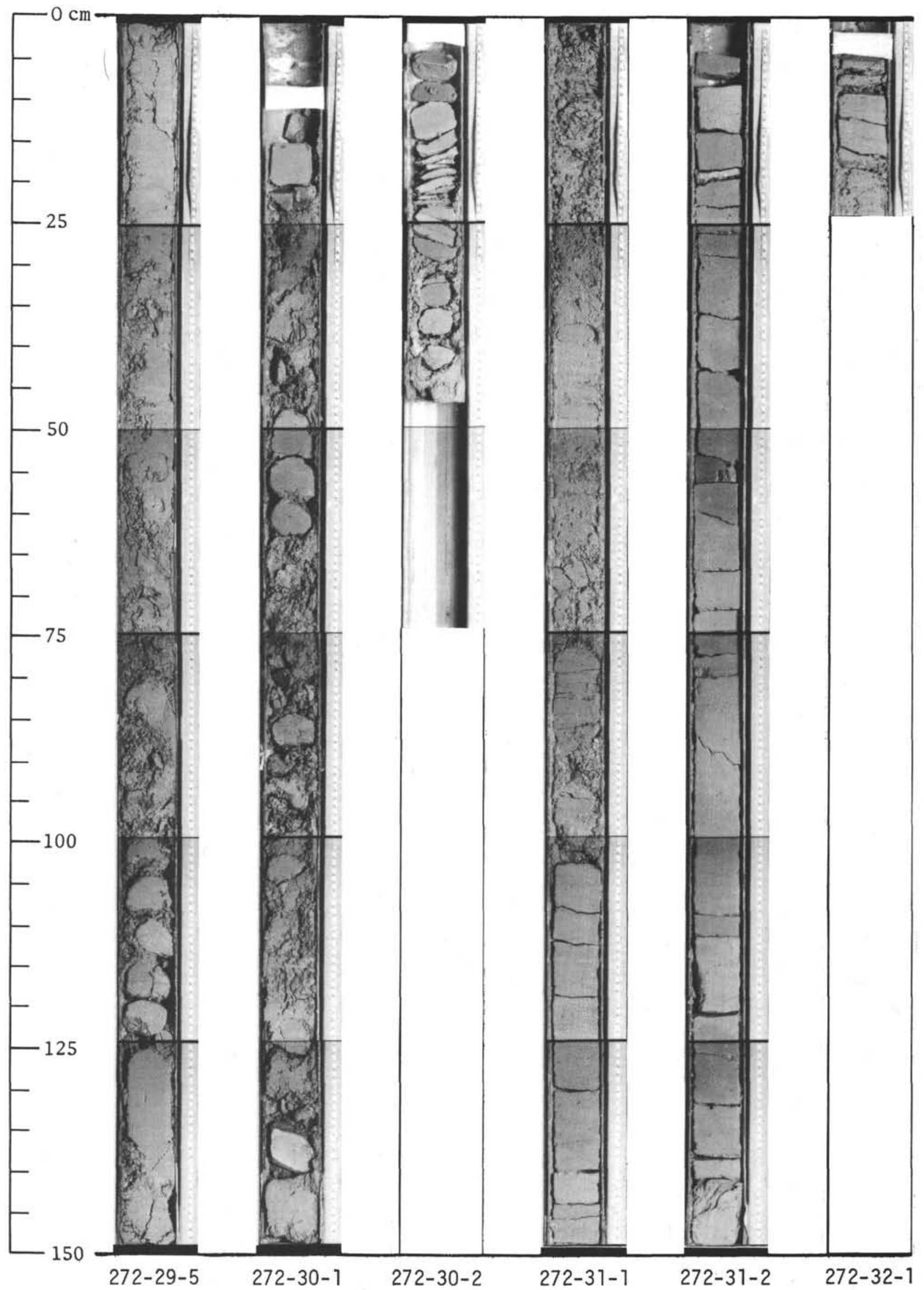




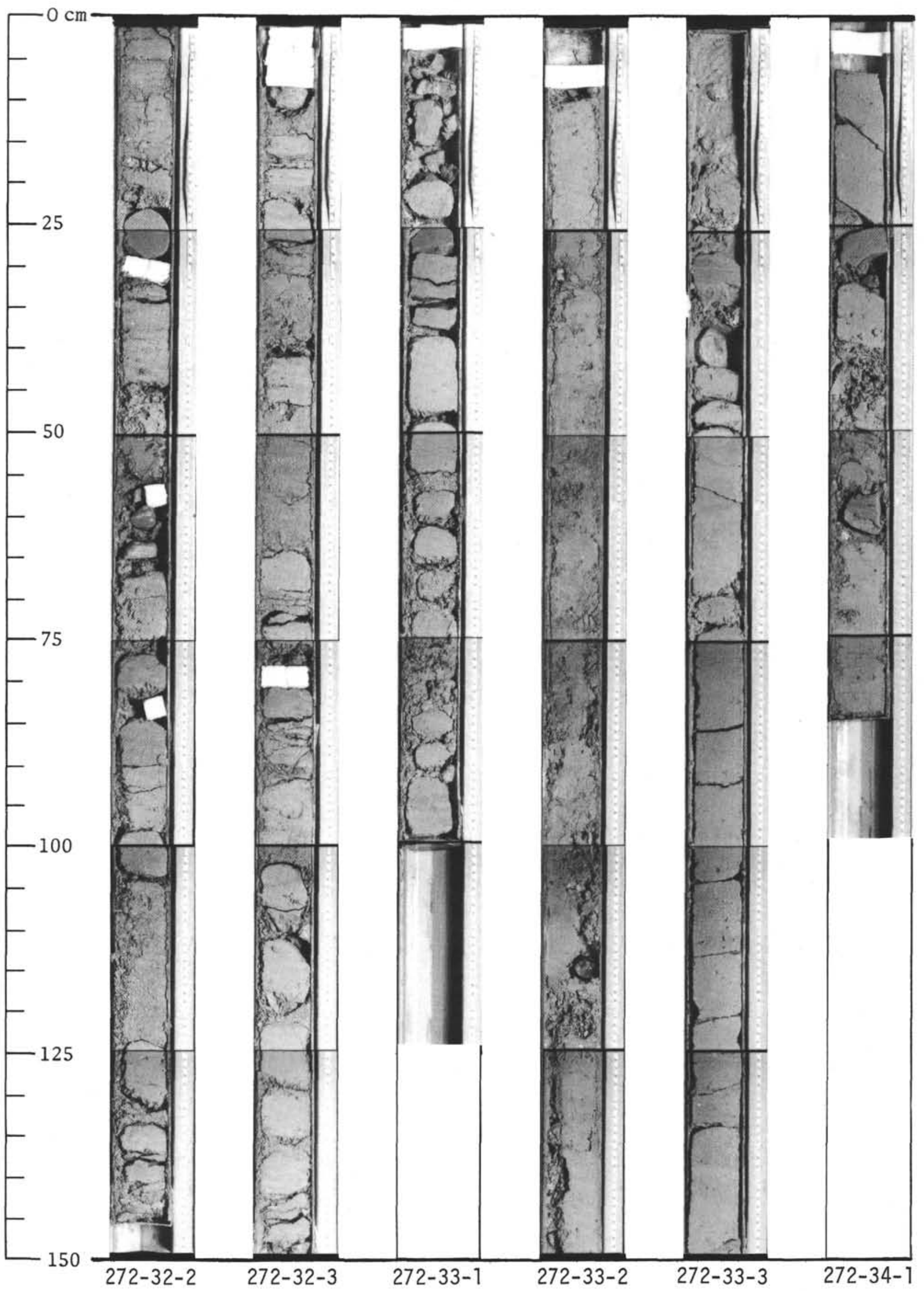


SITES $270,271,272$

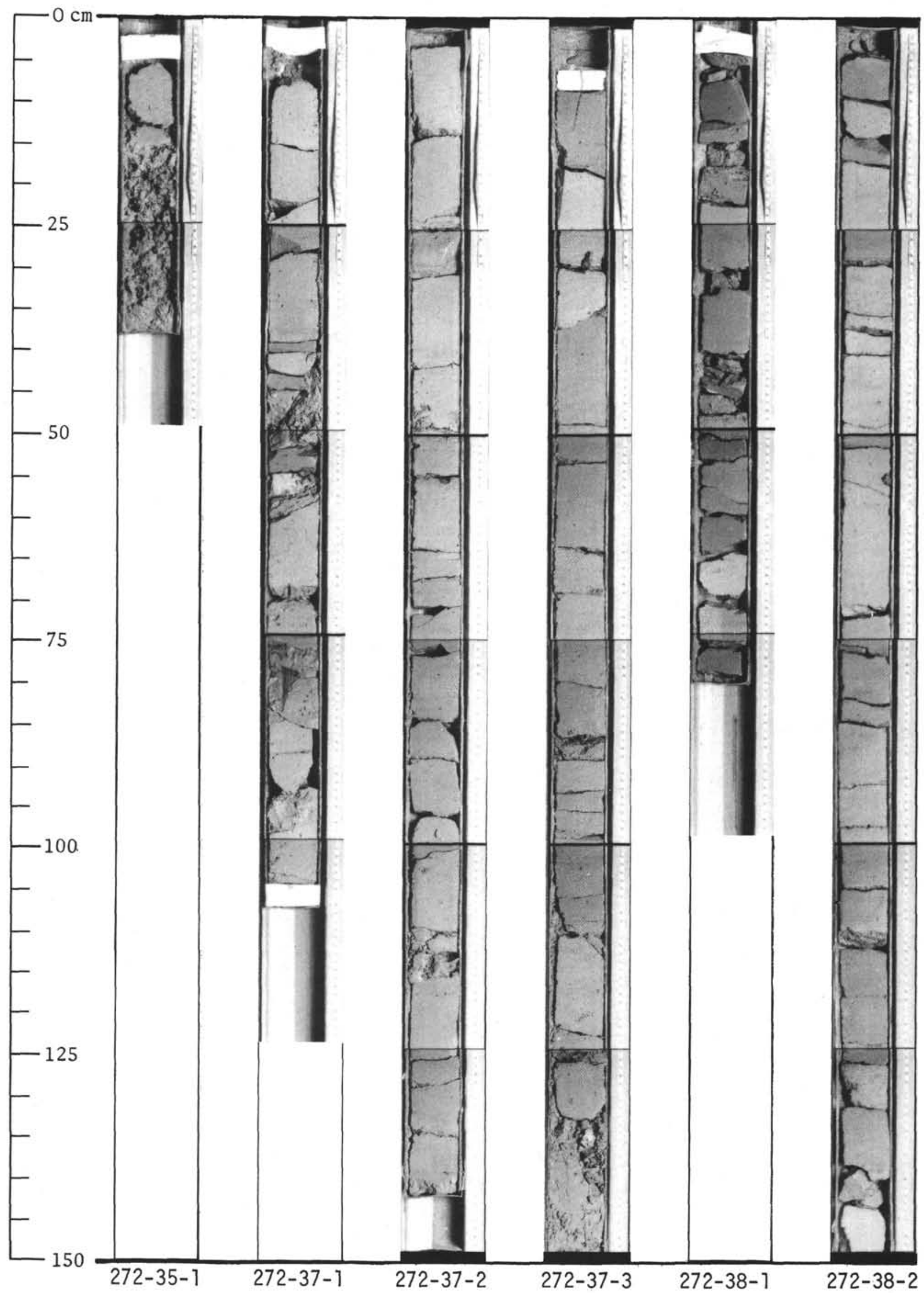


SITES 270, 271, 272

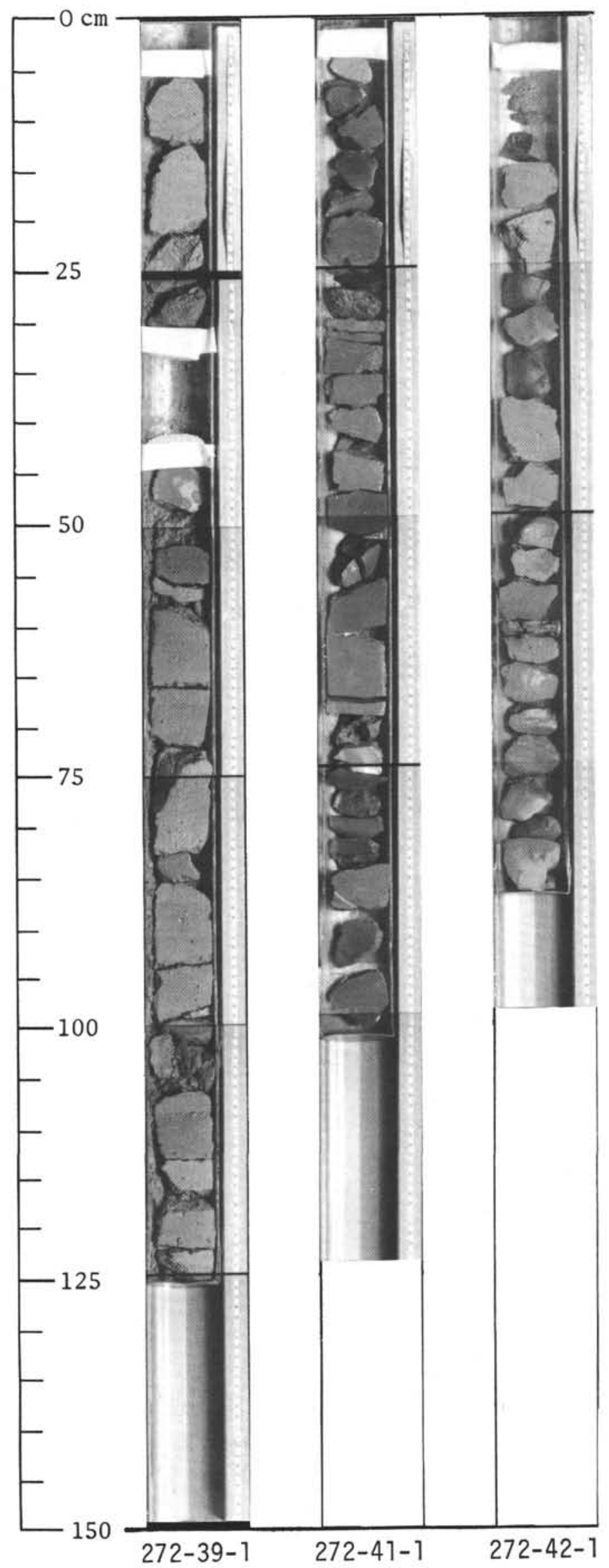

